МИНИСТЕРСТВО НАУКИ И ВЫСШЕГО ОБРАЗОВАНИЯ РФ

ФЕДЕРАЛЬНОЕ ГОСУДАРСТВЕННОЕ БЮДЖЕТНОЕ ОБРАЗОВАТЕЛЬНОЕ УЧРЕЖДЕНИЕ

ВЫСШЕГО ОБРАЗОВАНИЯ «КЕМЕРОВСКИЙ ГОСУДАРСТВЕННЫЙ УНИВЕРСИТЕТ» БЕЛОВСКИЙ ИНСТИТУТ (ФИЛИАЛ)

\title{
Н.С. Кузьмина
}

\section{ФИЗИЧЕСКАЯ КУЛЬТУРА}

\author{
Учебное пособие
}


МИНИСТЕРСТВО НАУКИ И ВЫСШЕГО ОБРАЗОВАНИЯ РФ ФЕДЕРАЛЬНОЕ ГОСУДАРСТВЕННОЕ БЮДЖЕТНОЕ ОБРАЗОВАТЕЛЬНОЕ УЧРЕЖДЕНИЕ ВЫСШЕГО ОБРАЗОВАНИЯ «КЕМЕРОВСКИЙ ГОСУДАРСТВЕННЫЙ УНИВЕРСИТЕТ» БЕЛОВСКИЙ ИНСТИТУТ (ФИЛИАЛ)

\author{
Н.С. Кузьмина
}

\title{
ФИЗИЧЕСКАЯ КУЛЬТУРА
}

Учебное пособие 


\title{
УДК 613.71:796(075.8)
}

\section{ББК $75 я 73$}

K89

\author{
Печатается по решению методического совета \\ Кемеровского государственного университета
}

\section{Рещензенты:}

\author{
Кафедра гуманитарных наук Беловского института (филиала) КемГУ; \\ Т.И. Шадрина, директор \\ МБУ «Информационно-методический центр города Белово»
}

Кузьмина, Н.С.

К89 Физическая культура : учебное пособие / Н.С. Кузьмина; Беловский институт (филиал) федерального государственного бюджетного образовательного учреждения высшего образования «Кемеровский государственный университет» [Электронный ресурс]. - Электрон. текстовые дан. - Красноярск: НИЦ, 2021. - 320 с. - Режим доступа: http://nkras.ru/arhiv/2021/KuzminaNS.pdf - Систем. требования: IBM PC; Internet Explorer и др.; Acrobat Reader 3.0 или старше.

\section{ISBN 978-5-907208-57-5 \\ DOI: 10.12731/978-5-907208-57-5}

Учебное пособие разработано по дисииплине «Физическая культура». Пособие содержит теоретические сведения в области физической культуры и спорта, практические задания, которые помогут студентам сформировать систему знаний по основам физического воспитания, профессионально-прикладной физической подготовки, здоровому образу жизни, организачии самостоятельных занятий и др., которая позволит им в будущей профессиональной деятельности правильно использовать средства физической культуры и спорта. Предназначается обучающимся дневной формы обучения всех специиальностей БИФ КемГУ.

\section{Свидетельство о регистрачии}

электронного издания сетевого распространения № 2046, зарегистрировано ФГУП НТЦ «Информрегистр» «16» марта 2021 г. и ему присвоен номер регистрации 0522100167.

ISBN 978-5-907208-57-5
(C) Кемеровский государственный университет, 2021

(C) Кузьмина Н.С., 2021

(C) Оформление. Научно-инновационный центр, 2021 


\section{СОДЕРЖАНИЕ}

ВВЕДЕНИЕ...................................................

ЧАСТЬ І. ТЕОРЕТИЧЕСКИЕ ПОЛОЖЕНИЯ КУРСА «ФИЗИЧЕСКАЯ

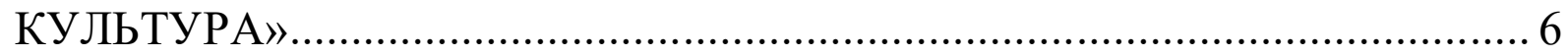

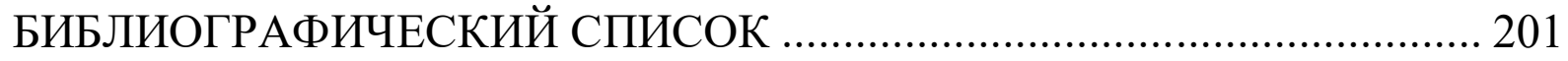

ЧАСТЬ ІІ. ПРАКТИЧЕСКИЕ РАБОТЫ ПО ИЗУЧЕНИЮ КУРСА.......... 204

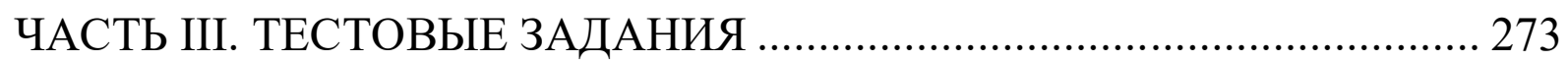

СПИСОК РЕКОМЕНДУЕМОЙ ЛИТЕРАТУРЫ ..................................... 317 


\section{ВВЕДЕНИЕ}

С развитием цивилизации роль физической культуры в жизни общества существенно возрастает. Это связано, прежде всего, с увеличением значимости показателей физического состояния человека в стандартах качества жизни, с влиянием негативных последствий современной цивилизации - гиподинамии, ухудшения экологии, курения, алкоголя, наркотиков и т.п. К тому же все более возрастающий ритм жизни требует от людей хороших психофизических кондиций. К сожалению, значительная часть населения, даже имея высокий образовательный уровень, не в состоянии правильно распорядиться своим психофизическим потенциалом, чтобы с помощью физических упражнений поддерживать оптимальную работоспособность и здоровье. Одна из основных причин недостаток соответствующих знаний и методических умений.

В связи с этим программа дисциплины «Физическая культура», предусматривает теоретический раздел, формирующий мировоззренческую систему научно-практических знаний и положительное отношение к физической культуре, и методико-практический раздел, обеспечивающий овладение методами и способами физкультурно-спортивной деятельности для достижения учебных, профессиональных и жизненных целей личности

Реальная ситуация в России ныне такова, что физические упражнения на учебных занятиях для значительной части студентов являются единственной возможностью получить хотя бы минимально необходимую двигательную нагрузку. Вместе с тем, в современном обществе физическая культура стала выполнять функции социального института, помогающего будущему специалисту хорошо ориентироваться в условиях рыночной конъюнктуры. Средства физической культуры используются для воспитания у студентов управленческой готовности, стремления к лидерству, успеху. В результате сопряженной учебной и 
физкультурно-спортивной деятельности возможно формирования $\mathrm{y}$ студентов и социально значимых качеств: социальной активности, самостоятельности, уверенности в своих силах, честолюбия. В процессе обучения будущие специалисты овладевают системой научно-практических и специальных знаний, необходимых для понимания естественных и социальных процессов функционирования физической культуры общества и личности.

Данное учебное пособие поможет студентам не только разобраться в сущности, задачах, целях и возможностях физической культуры и спорта в широком спектре их проявлений, но и подготовиться к итоговой аттестации по предмету. 


\section{ЧАСТЬ І. ТЕОРЕТИЧЕСКИЕ ПОЛОЖЕНИЯ КУРСА}

«ФИЗИЧЕСКАЯ КУЛЬТУРА»

Тема 1. Физическая культура в общекультурной и профессиональной подготовке студентов

\section{План:}

1.1. Основные понятия физической культуры и спорта

1.2. История развития физической культуры

1.3. Физическая культура студентов

1.4. Ценности физической культуры и спорта

\section{1. Основные понятия теории и методики физической культуры}

В теории физической культуры используются такие понятия, как «физическая культура», «спорт», «неспециальное физкультурное образование», «физическая рекреация», «двигательная реабилитация», «физическое развитие», «физическое воспитание», «физическая подготовка», «физическое упражнение» и многие другие. Эти понятия носят наиболее общий характер, а конкретные термины и понятия, так или иначе вытекают из определений более общих категорий.

Главным и наиболее общим из них является понятие «физическая культура». Как вид культуры она в общесоциальном плане представляет собой обширнейшую область творческой деятельности как научной, так и практической, а также результаты этой деятельности по созданию физической готовности людей к жизни. В личностном плане она является мерой и способом всестороннего физического развития человека. 
В том и другом случае физическая культура имеет решающее значение не сама по себе как область деятельности, а ее качественные результаты, степень эффективности, ценности, полезности для человека и общества. В более широком плане результативность этой деятельности может проявляться в состоянии физкультурной работы в стране, в ее материально-технической, теоретико-методической и организационной обеспеченности в конкретных показателях физического развития членов общества.

ФИЗИЧЕСКАЯ КУЛЬТУРА - эТО вид культурЫ, который представляет собой специфический процесс и результат человеческой деятельности, средство и способ физического совершенствования людей для выполнения ими своих социальных обязанностей.

ФИЗИЧЕСКОЕ ВОСПИТАНИЕ - процесс формирования потребности в занятиях физическими упражнениями в интересах всестороннего развития личности, формирования положительного отношения к физической культуре, выработка ценностных ориентации, убеждений, вкусов, привычек, наклонностей.

СПОРТ - вид физической культуры: игровая, соревновательная деятельность и подготовка к ней, основанные на использовании физических упражнений и направленные на достижение наивысших результатов.

Он направлен на раскрытие резервных возможностей и выявление предельных для данного времени уровней функционирования организма человека в процессе двигательной деятельности. Состязательность, специализация, направленность на наивысшие достижения, зрелищность являются специфическими признаками спорта как вида физической культуры [31].

ФИЗИЧЕСКАЯ РЕКРЕАЦИЯ - вид физической культуры: использование физических упражнений, а также видов спорта в 
упрощенных формах, для активного отдыха людей, получения удовольствия от этого процесса, развлечения, переключения с одного вида деятельности на другой, отвлечения от обычных видов трудовой, бытовой, спортивной, военной деятельности.

Она составляет основное содержание массовых форм физической культуры, представляет собой рекреативную деятельность.

ДВИГАТЕЛЬНАЯ РЕАБИЛИТАЦИЯ - вид физической культуры: целенаправленный процесс использования физических упражнений для восстановления или компенсации частично или временно утраченных двигательных способностей, лечения травм и их последствий.

Этот процесс осуществляется комплексно, под воздействием специально подобранных физических упражнений, массажа, водных и физиотерапевтических процедур и некоторых других средств. Это восстановительная деятельность [30].

ФИЗИЧЕСКАЯ ПОДГОТОВКА - вид неспециального физкультурного образования: процесс формирования двигательных навыков и развития физических способностей (качеств), необходимых в конкретной профессиональной или спортивной деятельности (физическая подготовка летчика, монтажника, сталевара и т.п.)

Она может определяться и как вид общей подготовки спортсмена (физическая подготовка спринтера, боксера, борца и т.п.).

ФИЗИЧЕСКОЕ РАЗВИТИЕ - процесс изменения форм и функций организма либо под воздействием естественных условий (питания, труда, быта), либо под воздействием целенаправленного использования специальных физических упражнений.

Это также и результат воздействия указанных средств и процессов, который можно измерить в данный конкретный момент (размеры тела и его частей, показатели различных двигательных качеств и способностей, функциональные возможности систем организма). 
ФИЗИЧЕСКИЕ УПРАЖНЕНИЯ - движения или действия, используемые для развития физических способностей (качеств), органов и систем, для формирования и совершенствования двигательных [31].

С одной стороны - это средство физического совершенствования, телесного преобразования человека, его биологической, психической, интеллектуальной, эмоциональной и социальной сущности. С другой стороны - это также и метод (способ) физического развития человека. Физические упражнения являются основным, "сквозным" средством всех видов физической культуры неспециального физкультурного образования, спорта, физической рекреации и двигательной реабилитации.

\section{2. История развития физической культуры}

Гармоничное сочетание интеллекта, физических и духовных сил высоко ценилось человеком на протяжении его развития и совершенствования. Великие мужи в своих трудах подчеркивали необходимость всестороннего развития молодежи, не выделяя приоритет физического или духовного воспитания, глубоко понимая; насколько переоценка, акцентированное формирование каких-либо качеств приводят к нарушению гармоничного развития личности.

Термин «культура», появившийся в период возникновения человеческого общества, далеко неоднозначен, тесно связан с такими понятиями; как «возделывание», «обработка», «воспитание», «образование», «развитие»; «почитание». Этот термин в современном обществе охватывает широкую сферу преобразовательной деятельности и ее результаты в виде соответствующих ценностей, в частности, «преобразование своей собственной природы».

Физическая культура - это часть (подсистема) общей культуры человечества, которая представляет собой творческую деятельность по 
освоению прошлых и созданию новых ценностей преимущественно в сфере развития, оздоровления и воспитания людей.

В целях развития, воспитания и совершенствования человека физическая культура использует возможности индивидуума, естественные силы природы, достижения наук о человеке, конкретные научные результаты и установки медицины, гигиены, анатомии, физиологии, психологии, педагогики, военного дела и др. Физическая культура, органически вплетаясь в профессионально-производственные, экономические, общественные отношения людей, оказывает на них существенное влияние, выполняя гуманистическую и культурно-творческую миссию, что сегодня, в период реформ высшей школы и пересмотра сущности предшествующих концепций, особенно ценностно и значимо [11].

Академик Н.И. Пономарев, опираясь на результаты исследования обширного материала, пришел к выводу, ставшему основополагающим для истории возникновения и первоначального развития физического воспитания, что «человек стал человеком не только в ходе развития орудий труда, но и в ходе постоянного совершенствования самого, человеческого тела. Организма человека как главной производительной силы». В этом развитии охота, как форма работы, сыграла решающую роль. Именно в этот период человек оценил преимущества новых навыков, жизненно необходимых движений, качеств силы, выносливости, быстроты.

Археология и этнография предоставили возможность проследить за развитием человека, следовательно, и физической культуры, с древнейших времен. Результаты научных исследований позволяют сделать вывод, что из трудовых движений, жизненно необходимых действий физическая культура выделилась в почти самостоятельный вид человеческой деятельности в период от 40 до 25 тысячелетий до н.э. Появление метательного оружия, а в дальнейшем и лука, способствовало 
необходимости подготавливать добытчиков пищи, воинов, развивать и совершенствовать уже тогда, в каменном веке, появившимися системами физического воспитания, двигательные качества как залог успешной охоты, защиты от врага и т.д.

Представляет интерес и то, что у многих народов появляются традиции и обычаи использования физической культуры, еe воспитывающего компонента в ритуалах посвящении при переходе из одной возрастной группы в другую. Например, юношам не разрешалось жениться, пока не будут выполнены определенные тесты - испытания, а девушкам - выходить замуж до тех пор, пока они не докажут приспособленность к самостоятельной жизни.

Так, на одном из островов архипелага Новые Гибриды ежегодно устраивались праздники, кульминацией которых были «прыжки с вышки» на суше (Л. Кун). Участник этого состязания, к щиколоткам которого была привязана закрепленная веревка из лиан, летит вниз головой с высоты 30 м. Когда голова почти касается земли, упругие лианы сокращаются и подбрасывают человека вверх, и он плавно приземляется на ноги. В те далекие времена не прошедшие это испытание не допускались к обряду посвящение, не могли появляться на [26].

Физическая культура первобытного периода, развивая стойкость, твердую волю, физическую подготовку каждого члена племени, воспитывала у соплеменников чувство общности в защите своих интересов.

Особый интерес представляет физическая культура Древней Греции, где «неграмотными считали тех, кто не умел читать, писать и плавать» (Агеевец В.У., 1983), физическое воспитание в древнегреческих государствах Спарте и Афинах, где преподавались гимнастика, фехтование, верховая езда, плавание, бег с 7-летнего возраста, борьба и кулачный бой - с 15-летнего. 
Примером, характеризующим уровень развития физической культуры в этих государствах, являлись организация и проведение Олимпийских игр.

Известные всему миру великие люди древности были и великими спортсменами: философ Платон - кулачный боец, математик и философ Пифагор - олимпийский чемпион, Гиппократ - пловец, борец.

Мифические герои, обладающие сверхъестественными физическими и духовными способностями, были у всех народов: Геракл и Ахиллес - у греков, Гильгамеш - у вавилонян, Самсон - у иудеев, Илья Муромец, Добрыня Никитич - у славян. Люди, возвеличивая их подвиги, победы в состязаниях, борьбе со злом и силами природы, стремились сами быть здоровыми, сильными, умелыми и трудолюбивыми, что, естественно, отражалось и на особенностях воспитания, физического воспитания, культуры физической.

Имеет смысл подчеркнуть значение физической культуры для греков словами великого Аристотеля: «Ничто так не истощает и не разрушает человека, как продолжительное физическое бездействие».

Военно-физическое воспитание характерно для средних веков. Воин-рыцарь должен был овладеть семью рыцарскими доблестями: верховой ездой, фехтованием, стрельбой из лука, плаванием, охотой, игрой в шахматы и умением слагать стихи.

Спорт как составная часть физической культуры наибольшего развития в капиталистическом обществе [26].

Различные формы физических упражнений были издавна известны русскому народу. Игры, плавание, ходьба на лыжах, борьба, кулачный бой, верховая езда и охота имели повсеместное распространение уже в Древней Руси. Широко применялись и различные игры: в лапту, городки, бабки, чехарду и многие другие. 
Физическая культура русского народа отличалась большим своеобразием и самобытностью. В физических упражнениях, распространенных среди русских в XIII-XVI вв. был ярко выражен их военный и полувоенный характер. Верховая езда, стрельба из лука, бег с препятствиями были на Руси любимыми народными развлечениями. Массовое распространение имели также кулачные бои, долгое время (вплоть до начала $\mathrm{XX}$ в.) игравшие большую роль в качестве одной из основных народных самобытных форм физического воспитания.

Большой популярностью среди русских пользовался бег на лыжах, катание на коньках и салазках и т.д. Одним из самобытных средств физического воспитания была охота, служившая не только промысловым целям, но и для того, чтобы показать свою ловкость и, бесстрашие (например, охота на медведя с рогатиной).

Чрезвычайно своеобразно проводилось на Руси закаливание. Общеизвестен русский обычай сразу после пребывания в жаркой бане обливаться холодной водой или обтираться снегом. Ценные самобытные виды физических упражнений были распространены и среди других народов, вошедших в состав созданного позже многонационального русского государства.

Появление и укрепление дворянской империи Петра I (XVIII в.) сказалось в известной мере и на государственном влиянии на развитие физической культуры. Это коснулось, прежде всего, боевой подготовки войск, физического воспитания в учебных заведениях и отчасти воспитаний дворянства.

Именно в эпоху реформ Петра I физические упражнения стали впервые применяться в России в системе обучения солдат и офицеров. Одновременно физические упражнения, главным образом фехтование и верховая езда, вводятся как учебная дисциплина в Московской школе математических и навигационных наук (1701 г.), в Морской академии и 
других учебных заведениях. При Петре I занятия физическими упражнениями вводятся также в гражданских гимназиях, организуются занятия молодёжи гребным и парусным спортом. Эти меры явились первыми шагами государства по руководству делом физической культуры.

В дальнейшем физические упражнения все более применяются в учебных заведениях, и особенно в системе воинского воспитания. Большая заслуга в этом принадлежит великому русскому полководцу А.В. Суворову.

Во второй половине XIX в. среди молодежи начинает развиваться современный спорт в форме спортивных кружков и клубов. Появляются первые гимнастические и спортивные общества и клубы. В1897 г. в Петербурге была создана первая футбольная команда, а в 1911 г. организован Всероссийский футбольный союз, объединивший 52 клуба.

В начале XX в. в Петербурге возникли спортивные общества: «Маяк», «Богатырь». Различные спортивные организации и клубы объединяли к 1917 г. довольно большое число спортсменов-любителей. Однако условий для развития массового спорта не было. Поэтому в условиях дореволюционной России отдельным спортсменам удавалось показывать результаты международного класса только благодаря природным данным и настойчивости, с какой они тренировались. Это всем известные - Поддубный, Заикин, Елисеев и др.

С приходом советской власти, преследуя цель массовой военной подготовки трудящихся и воспитания физически закаленных бойцов армии, в апреле 1918 г. был принят Декрет об организации всеобщего военного обучения (Всеобуча). За короткий срок было построено 2 тыс. спортплощадок, В 1918 г. организуется первый в стране ИФК в Москве и Ленинграде. Остро встал вопрос об укреплении в стране государственных форм руководства физкультурной и спортивной работой. 27 июля 1923 г. 
издается Декрет ВЦИК РСФСР об организации научной, учебной и организационной работы по физическому воспитанию.

Принятое 13 июля 1925 г. постановление ЦК РКП (б) «О задачах партии в области физической культуры» явилось программой развития физкультурного движения в новых условиях социалистического общества. В постановлении были определены сущность физической культуры и ее место в советском государстве, подчеркнуто ее воспитательное значение, указано на необходимость вовлечения в физкультурное движение широких масс рабочих, крестьян, учащейся молодежи.

В честь 10-летия физической культуры в СССР (считая с момента организации Всеобуча) в 1928 г, была проведена Всесоюзная спартакиада, привлекшая свыше 7 тыс. участников.

В 1931-1932 гг. вводится разработанный специальной комиссией Всесоюзного совета физической культуры при ЦИК СССР физкультурный комплекс «Готов к труду и обороне СССР». Только за годы существования комплекса его нормы сдали свыше 2,5 млн. человек. В 1939 г. ввели новый усовершенствованный комплекс ГТО и в этом же году учреждается ежегодный праздник - Всесоюзный день физкультурника. Политика государства была направлена и на развитие массового туризма. Секции туризма, альпинизма - скалолазания и позже спортивного ориентирования были в послевоенные годы почти в каждом учебном заведении, на предприятиях, заводах. Стала развиваться клубная система. Туристические клубы стали методическими и учебными центрами. При клубах готовились инструктора, тренеры, руководители секций. Следует сказать о том, что первый туристский клуб в СССР был организован в городе Ростове-на-Дону в 1937 г. Это был универсальный клуб, в котором объединились любители всех видов путешествий. Помещение клуба было очень скромным. Он располагался в двух больших задах. Вот как писал о планах работы клуба журнал «На суше и на море»: «Здесь туристы имеют 
возможность обменяться опытом в работе, обсудить планы своих путешествий, получить консультацию организовать учебу по технике туризма. Несомненно, что форма клубно-туристской работы целиком и полностью оправдает себя [29].

На стенах комнат размещен методический, консультационный и справочный материал по всем видам самодеятельного туризма. Здесь имеется уголок альпиниста, водника, велосипедиста и пешехода.

До Великой Отечественной войны Ростовский клуб туристов так и остался единственным в стране. После войны он был организован вновь в октябре 1961 г.

В годы Великой Отечественной войны советские спортсмены внесли свою лепту в победу над врагом. Ряду спортсменов было присвоено звание Героя Советского Союза. Неоценимую помощь Советской Армии оказывали лыжники, пловцы.

В 1957 г. было более 1500 стадионов, свыше 5 тыс. спортплощадок, около 7 тыс. гимнастических залов, открыт стадион им. В.И. Ленина в Лужниках и т.д.

После 1948 г. спортсмены СССР свыше 5 тыс. раз обновляли всесоюзные рекорды в почти тысячу раз - мировые. Большую роль играли проходившие Спартакиады народов СССР.

С каждым годом расширяются международные связи в спорте. Мы являемся членами Международного Олимпийского комитета (МОК), Международного совета физического воспитания и спорта (СИЕПС), Международной федерации спортивной медицины (ФИМС) и многих других, членами Международной федерации по 63 видам спорта.

Российский студенческий спортивный союз (РССС) был создан в 1993 г. В настоящее время РССС признан как единый орган по руководству студенческим спортом Российской Федерации по высшему образованию. Министерства и ведомства, имеющие в своем ведении 
высшие учебные заведения, Госкомитет России по физической культуре и туризму, РССС активно сотрудничают с Олимпийским комитетом России, являясь его членом, с правительственными органами, различными молодежными организациями. РССС вступил в Международную федерацию университетского спорта (ФИСУ), принимает активное участие во всех, его мероприятиях.

РССС объединяет спортивные клубы, различные физкультурные организации более 600 высших и 2500 средних специальных учебных заведений страны. В структуре РССС созданы региональные органы руководства студенческим спортом. Для занятий спортом в распоряжение студентов предоставлены спортивные залы, стадионы, плавательные бассейны, лыжные базы, спортивные площадки высших и средних учебных заведений. Для организации летнего отдыха в вузах функционируют 290 спортивно-оздоровительных лагерей. Около 10 тыс. специалистов ведут регулярные занятия по физической культуре и спорту со студентами. В высших учебных заведениях России культивируется более 50 видов спорта, наиболее массовыми из них являются баскетбол, легкая атлетика, лыжные гонки, волейбол, футбол, настольный теннис, туризм, шахматы, спортивное ориентирование [30].

Российским студенческим спортивным союзом ежегодно проводятся национальные и региональные чемпионаты по видам спорта, включенным в программы Всемирных универсиад и чемпионатов мира среди студентов. По многим видам спорта студенты составляют большинство сборных команд России и принимают участие в чемпионатах Европы, мира и Олимпийских играх. РССС является правопреемником упраздненного студенческого ДСО «Буревестник», продолжает его идея и традиции. В ближайшей перспективе намечены проведение зимних и летних Всероссийских универсиад, регулярное издание своего печатного органа, создание фонда развития студенческого спорта, выпуск студенческих 
спортивных лотерей и другие мероприятия, направленные на реализацию уставных задач [26].

Повышается роль физического воспитания и высших учебных заведений. Его задачи: воспитание у студентов волевых и физических качеств, сознательности, подготовки к труду и защите Родины; сохранение и укрепление здоровья; профессионально-прикладная физическая подготовка с учетом будущей трудовой деятельности; приобретение студентами необходимых знаний по основам теории, методики и организации физического воспитания и к спортивной тренировки; подготовка к работе в качестве общественных инструкторов и судей по спорту; совершенствование спортивного мастерства студентов. Занятия проводятся на всем протяжении теоретического обучения на всех курсах.

\section{3. Физическая культура студентов}

Физическая культура студентов представляет собой неразрывную составную часть высшего гуманитарного образования. Она выступает качественной и результирующей мерой комплексного воздействия различных форм, средств и методов на личность будущего специалиста в процессе формирования его профессиональной компетенции. Материализованным результатом этого процесса является уровень индивидуальной физической культуры каждого студента, его духовность, уровень развития профессионально значимых способностей [31].

Содержание физической культуры студентов, стратегия приоритетных направлений в её развитии подвержены активному влиянию социально-экономических факторов. Государственная политика в области высшего образования определяет социальный заказ на будущего специалиста и степень его физической готовности. Существенным недостатком содержания физической культуры студенческой молодежи 
80-х годов является её несомненный консерватизм, унитарность и выраженная деперсонализация (неспособность человека к личностному самовыражению в отношениях с другими людьми). Поэтому, на современном этапе перехода вузов Российской Федерации на многоуровневую систему образования, остро встала проблема поиска новых нетрадиционных подходов, позволяющих повысить её эффективность.

Закон Российской Федерации «Об образовании» предоставляет широкие возможности для переосмысления ценностей физической культуры студентов, в новом спектре осветить её образовательные, воспитательные и оздоровительные функции. Этот закон определяет содержание физической культуры студентов как самостоятельную сферу деятельности в федеральном социокультурном пространстве, выделяя при этом её образовательные приоритеты.

Перед студенческой молодежью сегодня обществом поставлена глобальная социально-экономическая задача по интегрированию отечественного культурного потенциала в мировое сообщество. Однако её реализация по силам только специалистам новой формации, отвечающим по целому комплексу профессиональных и личностных качеств современным требованиям. Помимо глубоких профессиональных знаний по избранной специальности такой специалист должен обладать: высокими физическими кондициями и работоспособностью, личной физической культурой, духовностью, неформальными лидерскими качествами. Он должен не бояться конкуренции, уметь принимать самостоятельные решения, т.е. быть творчески мыслящей, активной и высоконравственной личностью. Наметившаяся сегодня стратегия развития физической культуры студентов, выражаемая в тенденции отхода от унитарной концепции, либерализации и последовательной гуманизации 
педагогического процесса является гарантом формирования специалиста новой формации.

Структура физической культуры студентов включает три относительно самостоятельных блока: физическое воспитание, студенческий спорт и активный досуг. Для деятельности студентов в сфере физического воспитания приоритетными являются образовательные аспекты.

Целью физического образования является удовлетворение объективной потребности студентов в освоении системы специальных знаний, приобретении профессионально значимых умений и навыков. В соответствии с 12 статьей «Основ законодательства Российской Федерации о физической культуре и спорте» в круг обязанностей специалистов, работающих в сфере студенческой физической культуры входит проведение мероприятий по формированию потребностей студентов в здоровом образе жизни и самосовершенствовании. Гуманистическая направленность педагогического процесса предполагает целенаправленную интеграцию биологических и социальных потребностей, интеллектуальных и нравственных аспектов при реализации генетически обусловленных природных задатков каждого студента на протяжении его обучения в вузе [26].

Таким образом, создаются объективные предпосылки к преодолению односторонности и фрагментарности подготовки специалистов в вузе, приданию педагогическому процессу комплексного, целостного характера. Объективным критерием эффективности этого концептуального подхода является существенное сокращение сроков социально-психологической адаптации студентов к обучению в вузе, повышение их социальной активности, качественное повышение учебно-познавательной продуктивности, повышение духовности личности каждого студента. 
Студенческий спорт представляет собою обобщенную категорию деятельности студентов в форме соревнования и подготовки к нему с целью достижения предельных результатов в избранной спортивной специализации. Это требует от студента проявления максимальных психофизических кондиций, мобилизации его резервных возможностей.

Занятия спортом выступают формой самовыражения и самоутверждения студента, определяя его образ жизни, общекультурные и социально значимые приоритеты. На передний план в спорте выдвигается стремление к успеху, поощряется стремление личности к реализации своих возможностей в рамках определенного спортивного сценария. Результатом сопряженной учебной и спортивной деятельности студентов является формирование социально значимых качеств: социальной активности, самостоятельности, уверенности в своих силах, а также честолюбия [24].

В сфере активного досуга реализуются, главным образом, биологические потребности студентов в двигательной активности, здоровом образе жизни, получении удовольствия от занятий различными формами физической культуры. Высокая вариативность выбора студентами формы активного досуга подвержена сильному влиянию флуктуации культурных и социальных факторов, синергично взаимодействующих с биологическими запросами личности.

Трехкомпонентная структура физической культуры студентов определяет специфику выделения дифференцированных целей и педагогических задач каждого её структурного блока. Тем не менее, это не является существенным препятствием к определению генеральной цели физической культуры студентов: целенаправленного формирования гармонично развитой, высоко духовной и высоконравственной личности, квалифицированного специалиста, овладевшего устойчивыми знаниями и навыками в сфере физической культуры. 
Занятия по физическому воспитанию строятся таким образом, чтобы обеспечить максимальный профессионально-прикладной эффект при воспитании предприимчивости, оригинальности мышления, настойчивости, честолюбия, интуиции, способности идти на риск [15].

Стратегия приоритетных направлений государственной политики в сфере физкультурного образования студентов, отражающая возрастание количество сверхсложных систем и технологий, информатизацию всех сфер жизни общества, определяет новые требования к творческой подготовке будущего специалиста, его готовность к высокопроизводительному труду. Их реализация связана с раскрытием психофизических возможностей студенческой молодежи, гармоническим развитием ее физических, интеллектуальных и духовных сил путем использования физических упражнений, различных видов двигательной активности, рационального питания, природосообразного режима труда и отдыха. Используемая с этой целью физкультурная деятельность связана с физическим упражнением, сущность которого отражает целенаправленно выполняемые двигательные действия, включающими как моторно-исполнительные (операционные механизмы), так и познавательные, проектно-смысловые и эмоционально-оценочные аспекты. Таким образом, свои развивающие и формирующие функции физическая культура студентов наиболее полно реализует в системе физического воспитания, направленного на решение следующих основных задач:

всестороннее развитие физических способностей и на этой основе укрепление здоровья и обеспечение высокой работоспособности;

$>$ овладение техникой двигательных действий различных видов спорта;

овладение специальными знаниями, формирование потребности систематически заниматься физическими упражнениями; 
$>$ обеспечение необходимой физической подготовленности в соответствии с требованиями избранной профессии;

$>$ освоение организаторских умений и навыков по проведению самостоятельных форм занятий физической культурой [29].

Одной из важнейших задач в преподавании учебной дисциплины «Физическая культура» является внедрение в молодежную среду ценностей физического воспитания, которое рассматривается как базовый фактор физкультурного образования, способствующий общему и профессиональному развитию личности.

\section{Контрольные вопросы}

1. Что такое физическая культура?

2. Какие функции имеет физическая культура?

3. Что такое физическое совершенство?

4. Что относится к показателям физического совершенства?

5. Что такое физическое воспитание?

6. На каких принципах основывается отечественная система физического воспитания?

7. Что такое физическое развитие?

8. Из каких разделов состоит учебный материал дисциплины «Физическая культура»?

9. На какие учебные отделения распределяются студенты?

10. Какие основные зачетные требования? 17

11. Что включает итоговая аттестация по учебной дисциплине «Физическая культура»? 
Тема 2. Основы здорового образа жизни. Физическая культура в обеспечении здоровья

\section{План:}

2.1. Социальные аспекты здоровья и здорового образа жизни

2.2. Факторы, влияющие на здоровье

2.3. Условия и образ жизни

2.4. Организация, содержание и методика физической тренировки в оздоровительной физической культуре

2.4.1. Общие эффекты физической тренировки

2.4.2. Место физической культуры в поддержании и укреплении здоровья взрослых

\section{1. Социальные аспекты здоровья и здорового образа жизни}

В ряду общечеловеческих ценностей, определяющих социально-экономическую политику государства, несомненен приоритет здоровья. Именно так было, например, в Древней Греции, где культ тела возводился в ранг государственных законов, а в Древней Спарте занятия физическими упражнениями предписывались (и строго контролировались государством) для всех граждан высокий уровень их здоровья остается эталонам для многих десятков и сотен последующих поколений.

Пионер валеологии И.И. Брехман писал: «Именно здоровье людей должно служить главной «визитной карточкой» социально-экономической зрелости, культуры и преуспевания государства» [4]. Вот почему все вопросы обеспечения, формирования, сохранения и укрепления здоровья должны красной нитью пронизывать каждый из аспектов деятельности государства. Естественно, что это требует серьезнейшей планирующей, 
координирующей, регламентирующей и других видов работ, причем важно, чтобы сама эта работа строилась с ориентировкой на будущее.

Здоровье относится к универсальному, имеющему и материальный и духовный аспекты, феномену. Н.А. Добролюбов отмечал, что болезни и патологические расстройства не дают человеку «возможности исполнять своего назначения» и совершать «возвышенную духовную деятельность» [2].

Для государства здоровье или болезнь каждого ее гражданина имеют определенное конкретное материальное выражение. Прежде всего, оно должно выплачивать больному деньги по больничному листу, оплачивать его лечение; кроме того, больной не вырабатывает материальных ценностей (либо за него должны работать другие люди), что сказывается на величине валового национального продукта. С другой стороны, работник, систематически занимающийся своим здоровьем, производит продукции значительно больше, чем тот, кто на свое здоровье не обращает внимания.

Право граждан России на здоровье утверждается Конституцией Российской Федерации. К сожалению, это право не находит своего реального подтверждения. Реализация права на здоровье требует разработки специальной комплексной программы поддержания и охраны здоровья, в которой было бы определено место каждого социально-экономического звена: семьи, школы, органов здравоохранения, предприятий, физкультурных организаций, государства и др. Но все это потребовало бы и нового мышления, переосмысления концептуальной модели здоровья с учетом того, что в формировании здоровья населения важное место принадлежит поведенческим факторам: режиму труда и отдыха, взаимоотношениям в семье и на производстве и т.д., а также условиям жизни и образу жизни. Функциональной же структурой понятия «образ жизни» являются такие аспекты, как трудовая, социальная, 
интеллектуальная (психологическая установка, характер умственной деятельности), физическая и медицинская активность. То есть в проблеме здоровья, прежде всего, выделяются социальные и личностные предпосылки и лишь в последнюю очередь - медицинские. В этом отношении представляют интерес данные о зависимости отдельных заболеваний и нарушений от различных факторов [18].

Из всех приведенных заболеваний и нарушений (а на их долю приходится более 90\% смертельных исходов в стране), лишь в двух случаях (диабет, пневмония) решающим фактором риска является не образ жизни. Этот пример с несомненностью показывает значение валеологического образования, существенной частью которого должно быть формирование у человека приоритета здоровья и мотивации на здоровый образ жизни. Однако в сложившейся ситуации решение возможно лишь при координации усилий всех государственных и внегосударственных институтов, имеющих дело с человеком, - без этого невозможно всерьез приступить к разрешению острой проблемы здоровья $[2]$.

Решение вопросов здоровья на государственном уровне требует учета, по крайней мере, следующих групп факторов:Правовые, разработка законодательных и нормативных подзаконных актов, подтверждающих право граждан России на здоровье и регламентирующих механизмы его реализации через все государственные, хозяйственные и социальные институты от федерального до муниципального уровней, предприятий, учреждений и самих граждан.

Социально-экономические, обусловливающие виды, формы участия и ответственность различных звеньев социально-экономических структур в формировании, сохранении и укреплении здоровья своих членов, формирование такой работы и обеспечение нормативных условий для профессиональной деятельности. 
Образовательно-воспитательные, обеспечивающие формирование жизненного приоритета здоровья, воспитание мотивации на здоровый образ жизни (ЗОЖ) и обучение методам, средствам и способам достижения здоровья, умению вести пропагандистскую работу по здоровью и здоровому образу жизни.

Семейные, связанные с созданием условий для ЗОЖ в семье и ориентацией каждого из ее членов на здоровье, на финансирование в семье उОЖ.

Медицинские, направленные на диагностику состояния здоровья, разработку рекомендаций по ЗОЖ, эффективную первичную, вторичную и третичную профилактику.

Культурологические, связанные с формированием культуры здоровья, организацией досуга населения, популяризацией вопросов здоровья и ЗОЖ, этнических, общинных, национальных, религиозных и других идей, традиций, обрядов обеспечения здоровья и т.д.

Юридические, обеспечивающие социальную безопасность, защищенность личности от преступлений и угроз преступлений, грозящих жизни и здоровью граждан.

Экологические, обусловливающие адекватное для ЗОЖ состояние окружающей среды и рациональное природопользование.

Личностные, ориентирующие каждого конкретного человека на формирование, сохранение и укрепление своего здоровья и устанавливающие ответственность личности за свое здоровье [1].

Представленный далеко не полный перечень факторов, обеспечивающих поддержку здоровья граждан со стороны государства, предполагает координацию усилий ведомств и структур, компетентных за решение тех или иных аспектов здоровья. Имеющиеся в настоящее время программы санитарного просвещения населения ориентированы лишь на медицинские аспекты здоровья, не учитывают психолого-педагогические 
проблемы,! развития личности, ее индивидуальные, типологические, возрастные и половые особенности. Не вызывает сомнения культурологическая сторона проблемы, поскольку культура отражает меру осознания и овладения человеком своими отношениями к самому себе, к обществу, к природе, степень и уровень саморегуляции его сущностных потенций. Культура есть особый деятельностный способ освоения человеком мира, включая как внешний мир - природу и общество, так и внутренний мир самого человека в смысле его формирования и развития. Последнее обстоятельство характеризует культуру как искусственный, отличный от природного мир явлений, который замечателен тем, в частности, что не может существовать без ухода, без человеческой заботы.

Если рассматривать культуру как способность видеть мир во всем многообразии его взаимоотношений, в которых особая роль принадлежит человеку, то не знать своей организм, не осознавать свое место в природе, не уметь регулировать свое состояние недостойно культурного человека. Не зря поэтому известный физиолог В.Я. Данилевский отмечал: «Культурность населения и его материальная обеспеченность понижают смертность и заболеваемость, удлиняют продолжительность жизни». Примечательно, что ученый отдал приоритет культуре, a не материальному достатку, так как социально-экономическое положение страны не всегда пропорционально здоровью ее граждан. Так, средняя продолжительность жизни в Японии составляет около 80 лет, хотя уровень жизни в этой стране ниже, чем в США или Западной Европе, а интенсивность труда выше. Однако в Японии существует традиционность жизненного уклада и специфическая диета, японцы меньше курят и употребляют алкоголя. Важно, что все эти особенности культуры и жизненного уклада являются результатом глубоко усвоенных в семье и в школе морально-этических установок. 
Культура здоровья личности характеризуется жизненными позициями человека (наличием позитивных целей и ценностей); грамотным и осмысленным отношением к своему здоровью, природе и обществу; организацией здорового образа жизни, позволяющего активно регулировать состояние человека с учетом индивидуальных особенностей организма, реализовывать программы самосохранения, самореализации, саморазвития, приводящих к гармоничному единству всех компонентов здоровья и целостному развитию личности.

Рассматривая культуру здоровья с позиций системно-структурного подхода, ее можно представить в виде целостной системы с присущим ей внутренним содержанием, внешними условиями и интегральным результатом, выражаемые согласованностью системообразующих, системонаполняющих и системообусловливающих факторов [6].

Системообразующими факторами являются состояние индивидуального здоровья человека в его динамике и практико-ориентированный здоровый образ жизни. При этом критерии состояния здоровья следует рассматривать с позиций наращивания или сохранения его количественного и качественного потенциала как при относительно высоком уровне здоровья, так и при наличии каких-либо отклонений, физических дефектов, тех или иных заболеваний.

Системонаполняющими компонентами культуры здоровья являются: духовно-нравственные ценности (в том числе ценности здоровья и ЗОЖ) и менталитет здорового стиля жизни; валеологическая грамотность (знание причин и механизмов формирования здоровья, организации ЗОЖ, навыки оздоровительной деятельности); оздоровительные технологии, направленные на физическое и психическое совершенствование личности.

Системообусловливающие факторы формирования культуры здоровья носят объективный и субъективный характер. К числу объективных можно отнести социальные и биологические факторы. 
Социальными факторами, на наш взгляд, являются: уровень социально-экономического развития общества, материальное благополучие граждан и уровень их жизни, государственная политика в области охраны здоровья, наличие «моды» на здоровье, задаваемой государственными и общественными структурами, развитие системы образования, здравоохранения, физического воспитания и др. К биологическим системообусловливающим факторам культуры здоровья личности можно отнести: генетически детерминированные и приобретенные предпосылки физического и психического развития личности, возрастные особенности и гетерохронность психофизиологических функций организма, условия существования индивида в конкретной экосистеме. Наиболее значимыми субъективными факторами являются мотивация на здоровье и наличие волевых качеств, необходимых для проявления активности личности, стремления к самосовершенствованию и самореализации, преодоления собственной инертности по отношению к здоровью и здоровому образу жизни [17].

Исходя из структуры личности, выделяются следующие компоненты культуры здоровья личности:

- мотивационно-личностный компонент, включающий совокупность норм и ценностей, обеспечивающих представление о роли и месте культуры здоровья в системе общественных отношений, развитие мотивации здорового образа жизни и повышения уровня здоровья, совершенствование свойств и качеств личности, обеспечивающих активную жизненную позицию по отношению к здоровью;

- когнитивный компонент - представляет собой целостную практико-ориентированную систему валеологических знаний и умений физического и психического саморазвития; 
- деятельностный компонент обеспечивает достижение определенного уровня здоровья через личностно-значимый и индивидуально-ориентированный здоровый образ жизни [19].

Современный человек знает о здоровье достаточно много, как и о том, что надо делать для его поддержания и достижения. Однако для того, чтобы эти накопленные человечеством знания начали давать результат, необходимо учесть и устранить целый ряд негативных обстоятельств, препятствующих их реальному воплощению. Укажем на некоторые:

1. В стране не существует последовательной и непрерывной системы обучения здоровью. На различных этапах возрастного развития человек получает информацию о здоровье в семье, в школе, в больнице, из средств массовой информации и т.д. Однако информация эта отрывочна,, случайна, не носит системного характера, зачастую противоречива и исходит иногда даже от некомпетентных людей, а порой и шарлатанов. Отсюда встает исключительной важности проблема разработки системы непрерывного валеологического образования, вооружающего человека от момента рождения до глубокой старости и методологией здоровья, и средствами и методами его формирования. Учитывая тенденции катастрофического падения уровня здоровья людей (и, прежде всего, детей и подростков) и неспособность органов здравоохранения справиться не только с профилактикой, но и с самим обвалом патологии, разработка системы непрерывного валеологического образования должна стать делом государственной важности. Такая система может и должна иметь своей основной задачей совместную работу валеологов, педагогов, врачей, психологов и других специалистов по сохранению и укреплению здоровья людей и профилактике различных форм социальной и профессиональной дезадаптации. Для этого должны быть разработаны концепция, программа, а отсюда - и организация валеологического образования на разных уровнях основного и Дополнительного образования. 
2. Формирование знаний человека о здоровье еще не гарантирует, что он будет, следуя им, вести здоровый образ жизни. Для этого необходимо создание у человека стойкой мотивации на здоровье. Рождаясь здоровым, самого здоровья человек не ощущает до тех пор, пока не возникнут серьезные признаки его нарушения. Теперь, почувствовав болезнь и получив временное облегчение от врача он все больше склоняется к убеждению о зависимости своего здоровья именно от медицины. Тем более такой подход освобождает самого человека от необходимости «работать над собой», жить в постоянном режиме ограничений и нагрузок. Культурный же человек, как отмечал И.И. Брехман, «не должен допускать болезни, особенно хронические, так как в подавляющем числе случаев они являются следствием образа жизни в течение довольно длительного времени: атеросклероз, ишемическая болезнь сердца, диабет, ожирение, алкоголизм...»

3. В настоящее время существующая санитарно-просветительская работа, проводимая через средства массовой информации под непосредственным контролем Минздрава России, ориентирует население преимущественно на лечение, а не предупреждение заболеваний. При этом не раскрываются факторы риска и, главное, пути их преодоления, не показываются функциональные возможности организма в противодействии неблагоприятным влияниям и в устранении уже наступивших начальных признаков заболевания. Вместо этого упор делается на фармакологию и предупреждение каких-либо самостоятельных действий человека даже функционального характера без ведома врача. Однако последний не подготовлен к тому, чтобы давать эффективные рекомендации по этим вопросам, поэтому чаще всего следует категорический запрет с назначением фармакологического лечения на фоне функционального и психологического покоя. 
4. В течение десятилетий в нашей стране не существовало приоритета здоровья. Более того, социальную защиту государство гарантировало, прежде всего, больным, даже несмотря на то, что в подавляющем числе случаев в имеющейся у него патологии повинен, как показывает анализ, сам человек. Складывалась парадоксальная ситуация: кто меньше думал о своем здоровье и, вкладывал меньше усилий в формирование валового национального продукта, от этого продукта получал больше, чем здоровый. В настоящее время ситуация изменилась мало. По-видимому, необходима разработка таких правовых актов, которые бы повысили ответственность человека за свое здоровье и установили бы его материальную зависимость от уровня здоровья так же, как и от уровня профессиональной подготовки.

5. Как следствие предыдущего положения, в стране отсутствует мода на здоровье. Средства массовой информации тиражируют вредные привычки, неконтролируемый и опасный секс, насилие, но мало внимания обращают на формирование гармонично развитого- физически и духовно - человека. Например, физический имидж человека среди важнейших личностных показателей назвали $85 \%$ респондентов в США и лишь 25\% мужчин и менее $40 \%$ женщин — в России.

6. В стране недостаточно внимания уделяется вопросам формирования культуры отдыха, где бы особый акцент делался на его активных формах. Отсутствие такой культуры делает человека заложником непродуманного, непланируемого времяпрепровождения, толкает к стремлению «убить время» у телевизора, алкоголем, ничегонеделанием и пр. В результате имеющееся у него время для рекреации, снятия последствий профессионального утомления и подготовки к следующему этапу деятельности используется с малой эффективностью и зачастую с отрицательным результатом [28]. 


\section{2. Факторы, влияющие на здоровье}

Эксперты ВОЗ в 80-х годах нашего столетия определили ориентировочное соотношение различных факторов обеспечения здоровья современного человека, выделив в качестве основных четыре производные. Используя последние, в 1994 г. Межведомственная комиссия Совета безопасности Российской Федерации по охране здоровья населения в Федеральных концепциях «Охрана здоровья населения» и «К здоровой России» определила это соотношение применительно к нашей стране следующим образом:

$>\quad$ генетические факторы - 15-20\%;

$>$ состояние окружающей среды - 20-25\%;

$>$ медицинское обеспечение - 10-15\%;

$>$ условия и образ жизни людей $-50-55 \%$. [2]

Содержание каждого из факторов обеспечения здоровья можно определить следующим образом.

Таблица 1 - Факторы, влияющие на здоровье человека

\begin{tabular}{|c|c|c|}
\hline $\begin{array}{l}\text { Сфера влияния } \\
\text { факторов }\end{array}$ & Факторы & \\
\hline & Укрепляющие здоровье & Ухудшающие здоровье \\
\hline Генетические & $\mid \begin{array}{l}\text { Здоровая наследственность. } \\
\text { Отсутствие } \\
\text { морфофункциональных } \\
\text { предпосылок возникновения } \\
\text { заболевание }\end{array}$ & $\mid$\begin{tabular}{|l} 
Наследственные \\
нарушения. \\
предрасположенность к заболеваниям.
\end{tabular} \\
\hline $\begin{array}{l}\text { Состояние } \\
\text { окружающей } \\
\text { среды }\end{array}$ & \begin{tabular}{|lr} 
Хорошие & бытовые \\
производственные \\
экологически \\
среда олагоприятная \\
\end{tabular} & \begin{tabular}{|l} 
Вредные условия быта и производства, \\
неблагоприятные климатические и \\
природные условия, экологически не \\
благоприятная среда обитания \\
\end{tabular} \\
\hline $\begin{array}{l}\text { Медицинское } \\
\text { обеспечение }\end{array}$ & $\begin{array}{|lr|}\text { Медицинский } & \text { скрининг, } \\
\text { высокий } & \text { уровень } \\
\text { профилактических } & \\
\end{array}$ & 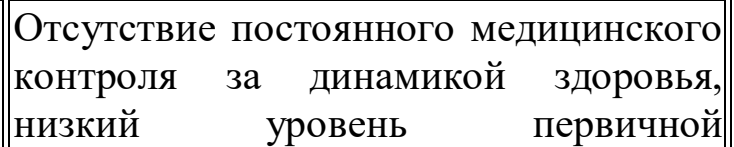 \\
\hline
\end{tabular}




\begin{tabular}{|c|c|c|}
\hline & $\begin{array}{l}\text { мероприятий, своевременная } \\
\text { и полноценная медицинская } \\
\text { помощь. }\end{array}$ & $\begin{array}{l}\text { профилактики, не качественное } \\
\text { медицинское обслуживание. }\end{array}$ \\
\hline $\begin{array}{l}\text { Условия } \\
\text { образ жизни }\end{array}$ & 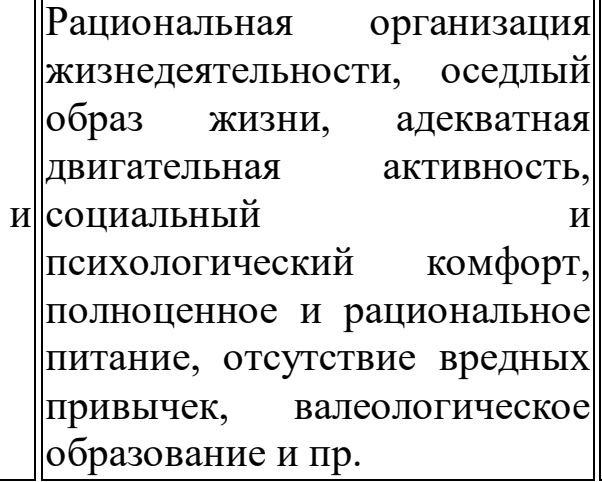 & $\begin{array}{l}\text { Отсутствие рационального режима } \\
\text { жизнедеятельности, миграционные } \\
\text { процессы, гипо- или гипердинамия, } \\
\text { социальный и психологический } \\
\text { дискомфорт, неправильное питание, } \\
\text { вредные привычки, недостаточный } \\
\text { уровень } \\
\text { образованности. }\end{array}$ \\
\hline
\end{tabular}

\section{3. Условия и образ жизни}

В последнее время, когда стало понятно, что медицина не может не только предотвратить, но и справиться с обрушившимся на нее обвалом патологии, интерес к здоровому образу жизни привлекает все более пристальное внимание и специалистов, и широких кругов населения. Это не в последнюю очередь обусловлено осознанием истинности и серьезности древнего изречения: искусство продлить жизнь - это искусство не укорачивать ее.

Сейчас становится все понятнее, что болезни современного человека обусловлены прежде всего его образом жизни и повседневным поведением. В настоящее время здоровый образ жизни рассматривается как основа профилактики заболеваний. Подтверждается это, в частности, тем, что в США снижение показателей детской смертности на 80\% и смертности всего населения на 94\%, увеличение ожидаемой средней продолжительности жизни на $85 \%$ связывают не с успехами медицины, а с улучшением условий жизни и труда и рационализацией образа жизни населения. Вместе с тем в нашей стране $78 \%$ мужчин и $52 \%$ женщин ведут нездоровый образ жизни [18]. 
В определении понятия здорового образа жизни необходимо учитывать два отправных фактора - генетическую природу данного человека и ее соответствие конкретным условиям жизнедеятельности.

Здоровый образ жизни есть способ жизнедеятельности, соответствующий генетически обусловленным типологическим особенностям данного человека, конкретным условиям жизни и направленный на формирование, сохранение и укрепление здоровья и на полноценное выполнение человеком его социально-биологических функций.

В приведенном определении здорового образа жизни акцент делается на индивидуализации самого понятия, то есть здоровых образов жизни должно быть столько, сколько существует людей. В установлении здорового образа жизни для каждого человека необходимо учитывать как его типологические особенности (тип высшей нервной деятельности, морфофункциональный тип, преобладающий механизм вегетативной нервной регуляции и т.д.), так и возрастно-половую принадлежность и социальную обстановку, в которой он живет (семейное положение, профессию, традиции, условия труда, материального обеспечения, быта и т.д.). Важное место в исходных посылках должны занимать личностно-мотивационные особенности данного человека, его жизненные ориентиры, которые сами по себе могут быть серьезным стимулом к здоровому образу жизни и к формированию его содержания и особенностей [2].

Отметим ряд ключевых положений, лежащих в основе здорового образа жизни:

1. Активным носителем здорового образа жизни является конкретный человек как субъект и объект своей жизнедеятельности и социального статуса. 
2. В реализации здорового образа жизни человек выступает в единстве своих биологического и социального начал.

3. В основе формирования здорового образа жизни лежит личностно-мотивационная установка человека на воплощение своих социальных, физических, интеллектуальных и психических возможностей и способностей.

4. Здоровый образ жизни является наиболее эффективным средством и методом обеспечения здоровья, первичной профилактики болезней и удовлетворения жизненно важной потребности в здоровье [1].

Таким образом, программа и организация здорового образа жизни для данного человека должны определяться следующими основными посылками:

1. индивидуально-типологическими наследственными факторами;

1. объективными социальными условиями и общественно-экономическими факторами;

2. конкретными условиями жизнедеятельности, в которых осуществляется семейно-бытовая и профессиональная деятельность;

3. личностно-мотивационными факторами, определяемыми мировоззрением и культурой человека, и степенью их ориентации на здоровье и здоровый образ жизни.

Достаточно часто, к сожалению, рассматривается и предлагается возможность сохранения и укрепления здоровья за счет использования какого-нибудь средства, обладающего чудодейственными свойствами (двигательная активность того или иного вида, пищевые добавки, психотренинг, очистка организма и т.п.). Попытки выделить доминирующий фактор и положить его в основу достижения здоровья предпринимаются давно. Так, Гиппократ в явлении «здорового образа жизни» специфическим элементом считал физическое здоровье человека (хотя и называл неправильное питание «матерью всех болезней»), 
Демокрит же в здоровом образе жизни приоритетным считал духовное начало. Очевидно, что стремление к достижению здоровья за счет какого-либо одного средства принципиально неправильно, так как любая из предлагаемых «панацей» не в состоянии охватить все многообразие взаимосвязей функциональных систем, формирующих организм человека, и связей самого человека с природой всего того, что в конечном итоге определяет гармоничность его жизнедеятельности и здоровье [19].

Структура здорового образа жизни должна представлять собой принципиальное единство всех сторон материально-бытового, природного, социокультурного и духовного бытия человека, реализуемого через структурный, энергетический и информационный каналы. Указанные каналы обеспечения здоровой жизнедеятельности человека отличаются двумя важными особенностями [1].

Любое средство действует на организм человека в целом, а не на одну какую-либо отдельную систему. Так, структурный аспект требует в своей реализации участия генетического аппарата всех клеток организма, ферментных систем, пищеварительной системы, дыхательного аппарата, терморегуляции и т.д. Такое же положение складывается и относительно двух остальных каналов обеспечения бытия человека.

1. Любое средство обеспечения жизнедеятельности реализуется практически через все три канала. Так, пища несет в себе и структурный, и энергетический, информационный потенциал; движение оказывается условием активизации пластических процессов, регулирует энергетический поток и несет важную для организма информацию, обеспечивающую в конечном итоге соответствующие структурные перестройки.

Таким образом, уклад жизни человека должен учитывать; сложность организации организма человека и многообразие его взаимоотношений с 
окружающей его средой, а сам человек должен определяться следующими характеристиками:

$>$ физическим состоянием, определяемым гомеостатическими показателями;

$>$ физическим развитием как процессом и результатом изменения в становлении естественных морфологических и функциональных свойств и параметрических характеристик организма в течение жизни;

$>$ физической подготовленностью как интегративным сложным компонентом физического совершенства человека;

$>$ психомоторикой как процессом, объединяющим, взаимосвязывающим психику с ее выражением - мышечным движением;

$>$ психическим состоянием сложным и многообразным, относительно стойким явлением, повышающим или понижающим жизнедеятельность в сложившейся ситуации;

$>$ психологическими свойствами личности человека, его обликом как дееспособного члена общества, сознающего свою роль и ответственность в нем;

$>$ социальным образованием реальности как продукта общественного развития и как субъекта труда, общения и познания, детерминированного конкретно-историческими условиями жизни общества;

$>$ духовностью как «одним из самых главных заблуждений человечества — это отрыв от материального» (по Н. Рериху).

Исходя из указанных предпосылок, структура здорового образа жизни должна включать следующие факторы:

$>$ оптимальный двигательный режим;

> тренировку иммунитета и закаливание;

$>$ рациональное питание;

> психофизиологическую регуляцию; 
> п психосексуальную и половую культуру;

$>$ рациональный режим жизни;

> отсутствие вредных привычек;

> валеологическое самообразование [6].

В последующем будет дан анализ основных из указанных факторов. Здесь же необходимо остановиться на последнем из них валеологическом самообразовании. Это обусловлено тем, что обеспечение здорового образа жизни возможно только при условии, что человек сам захочет быть здоровым. Показательно в этом отношении мнение Л.Н. Толстого, уделявшего много внимания здоровью: «Смешны требования людей курящих, пьющих, объедающихся, не работающих и превращающих ночь в день, о том, чтобы доктор сделал их здоровыми, несмотря на их нездоровый образ жизни».

Формирование здорового образа жизни имеет своей конечной целью совершенствование условий жизни и жизнедеятельности на основе валеологического обучения и воспитания, включающих изучение своего организма и своей личности, освоение гигиенических навыков, знание факторов риска и умение реализовать на практике весь комплекс средств и методов обеспечения здорового образа жизни. Осуществляя сознательную и целенаправленную здравотворческую деятельность, создавая среду обитания и деятельности, влияя на внешние условия, человек приобретает большую свободу и власть над собственной жизнью и обстоятельствами жизни, делая саму жизнь более плодотворной, здоровой и долголетней. Чтобы достичь этого, человек должен, прежде всего, стать носителем идеи здоровья как основного жизненного приоритета — эта проблема и является важнейшей задачей валеологического образования и самообразования.

Следующим этапом валеологического образования должно стать формирование определенной организации самосознания человека, ориентированного на понимание роли и места различных средств, методов 
и форм здорового образа жизни и на умение применить их в своей жизнедеятельности. При этом важно/что в каждом случае валеологическое образование становится элементом валеологической культуры именно данного человека, и здесь неприемлемы подходы массовой медицины, для которых свойственны всеобщие, единые нормы и рекомендации. С этих позиций под валеологической культурой следует понимать осознание человеком ценности здоровья в ряду жизненных приоритетов и определяющее его бережное отношение к своему здоровью и к здоровью окружающих людей [28].

Формирование здорового образа жизни осуществляется через информацию, получаемую человеком извне, и через коррекцию образа жизни благодаря обратной связи, анализу собственных ощущений, самочувствия и динамики объективных морфофункциональных показателей, их соотношения с имеющимися у него валеологическими знаниями. Формирование здорового образа жизни представляет собой исключительно длительный процесс и может продолжаться всю жизнь. Обратная связь от наступающих в организме в результате следования здоровому образу жизни изменений срабатывает не сразу, положительный эффект перехода на рациональный образ жизни иногда отсрочен на годы. Вот почему, к сожалению, довольно часто люди лишь «пробуют» сам переход, но, не получив быстрого результата, возвращаются к прежнему образу жизни. В этом нет ничего удивительного, так как здоровый образ жизни предполагает отказ от многих ставших привычными приятных условий жизнедеятельности (переедание, комфорт, алкоголь и др.) и, наоборот, - постоянные и регулярные тяжелые для неадаптированного к ним человека нагрузки и строгую регламентацию образа жизни. В первый период перехода к здоровому образу жизни особенно важно поддержать человека в его стремлении, обеспечить его необходимыми консультациями (так как в этот период он постоянно испытывает дефицит знаний в 
различных аспектах обеспечения здорового образа жизни), указывать на положительные изменения в состоянии его здоровья, в функциональных показателях и т.п.

Для формирования и осуществления здорового образа жизни может быть применима информационная система, плодотворно использующая и реализующая соответствующие системы физической культуры, медицины, кибернетики, физиологии, психологии, педагогики и т.д. и учитывающая основные особенности контингента и целей, условий и факторов, влияющих на валеологическую деятельность, организуемую и обеспечиваемую социальными и производственно-техническими, научно-информационными и коммуникационными инфраструктурами и Т.П [17].

Естественно, что путь каждого человека к здоровому образу жизни отличается своими особенностями как во времени, так и по траектории, но это не имеет принципиального значения - важен конечный результат. Эффективность же здорового образа жизни для данного человека можно определить по ряду следующих биосоциальных критериев:

1. Оценку морфофункциональных показателей здоровья:

4. уровень физического развития;

5. уровень физической подготовленности.

2. Оценка состояния иммунитета:

> количество простудных и инфекционных заболеваний в течение определенного периода;

$>$ при наличии хронического заболевания - динамику его течения.

3. Оценка адаптации к социально-экономическим условиям жизни:

> эффективность профессиональной деятельности;

$>$ активность исполнения семейно-бытовых обязанностей; 
$>$ широту и степень проявления социальных и личностных интересов.

4. Оценка уровня валеологических показателей:

> степень сформированности установки на здоровый образ жизни;

$>$ уровень валеологических знаний;

$>$ уровень усвоения практических знаний и навыков, связанных с поддержанием и укреплением здоровья;

умение самостоятельно построить индивидуальную траекторию здоровья и программу здорового образа жизни.

Суммируя данные об эффективности перехода к здоровому образу жизни, можно считать, что он:

положительно и результативно снижает или устраняет воздействие факторов риска, заболеваемость и как результат уменьшает затраты на лечение;

$>$ способствует тому, что жизнь человека становится более здоровой и долговечной;

$>$ обеспечивает хорошие взаимоотношения в семье, здоровье и счастье детей;

$>$ является основой реализации потребности человека в самоактуализации и самореализации, обеспечивает высокую социальную активность и социальный успех;

$>$ обусловливает высокую работоспособность организма, снижение усталости на работе, высокую производительность труда и на этой основе — высокий материальный достаток;

$>$ позволяет отказаться от вредных привычек, рационально организовать и распределять бюджет времени с обязательным использованием средств и методов активного отдыха;

$>$ обеспечивает жизнерадостность, хорошее, настроение и оптимизм. 
Следует отметить особую важность валеологического образования детей, которое является предпосылкой здорового начала будущих семей, способных родить, вырастить и воспитать последующие поколения людей с более совершенным генофондом и с устойчивой системой здоровых потребностей. Эффективность же валеологического образования детей, как показывает педагогическая практика, оказывается более высокой в связи с тем, что их нервная система более пластична, а существующие у них жизненные установки еще недостаточно прочны. Естественно, что это создает благоприятные возможности для воспитания у детей положительной мотивации на здоровье и ориентации их жизненных приоритетов.

2.4. Организация, содержание и методика физической тренировки в оздоровительной физической культуре

\subsection{1. Общие эффекты оздоровительной тренировки}

Систематические занятия целенаправленно спрограммированной физической культурой вызывают адаптацию организма к физическим нагрузкам. В основе такой адаптации лежат возникающие в результате тренировки морфологические, обменные и функциональные изменения в различных системах, органах и тканях, совершенствование нервной, гормональной и клеточной регуляции. Это проявляется в улучшении состояния организма, выражающемся в осуществлении мышечной деятельности, в повышении уровня физического развития и физической подготовленности.

Регулярное выполнение определенных 'видов физических упражнений вызывает многочисленные полезные эффекты в состоянии 
организма, которые можно систематизировать в двух основных следствиях:

I. Происходит все большая экономизация функций, проявляющаяся в том, что на единицу внешней работы организм затрачивает все меньший объем энергии. В основе экономизации лежит совершенствование двигательного динамического стереотипа, когда усиливаются процессы внутреннего торможения, способствующие локализации возбуждения только в зоне, непосредственно связанной с двигательными единицами, участвующими в осуществлении именно данного движения, все же остальные единицы выключены из работы - это, с одной стороны, не требует затраты энергии на их активность, а с другой - не мешает работе активных мышц. Именно поэтому при выполнении стандартной не максимальной нагрузки функциональные сдвиги у тренированного человека оказываются на более низком уровне, чем у нетренированного.

2. Усиливаются максимальные функциональные возможности организма. Основными механизмами этого феномена являются следующие: интенсифицируются процессы белкового синтеза в работающих мышцах, и в них появляется либо больше мышечных элементов, либо больше активных ферментов, участвующих в обеспечении процессов сокращения, либо имеют место оба явления вместе; в работающих, тканях накапливается больше энергетических субстратов, которые в зависимости от вида выполняемой тренировочной работы используются преимущественно в аэробных (работа на выносливость), либо в анаэробных (на силу, быстроту) условиях; совершенствуются процессы кислородного обеспечения мышечной деятельности за счет повышения функциональных возможностей сердечнососудистой и дыхательной систем, кислородной емкости крови и пр.; улучшаются процессы нервной регуляции мышечной деятельности, что проявляется в улучшении 
процессов возбуждения и торможения, их подвижности и уравновешенности [18].

Разумеется, степень выраженности тех или иных тренировочных эффектов зависит от вида выполняемой физической нагрузки. С точки зрения формирования здоровья, для обеспечения высокого уровня функционирования основных систем жизнеобеспечения оптимальными могут быть следующие средства.

Сердечнососудистая система и кровь. Наилучшими средствами для тренировки этих систем являются циклические упражнения: бег, ходьба, плавание, лыжи, велосипед и т.п. Основным режимом их использования должен быть аэробный, то есть таком, когда запрос кислорода на работу мышц в этих условиях полностью удовлетворяется в процессе самой работы и кислородный долг не образуется. Длительность непрерывного выполнения аэробного упражнения должна постепенно достичь 40-60 минут при не менее 3-4 занятий в неделю.

Длительные малоинтенсивные упражнения способствуют появлению многих благоприятных эффектов. Так, в крови возрастает количество эритроцитов, что ведет к нарастанию кислородной емкости крови, то есть каждая единица объема крови может перенести больший объем кислорода и углекислого газа. При этом важно, что старые эритроциты быстрее разрушаются, а вместо них появляются молодые, активность гемоглобина в которых выше. Другим результатом длительных аэробных упражнений является снижение концентрации холестерина в крови, что является важным фактором профилактики атеросклероза. Вместе с тем, уже появившиеся на стенках сосудов атеросклеротические бляшки постепенно разрушаются и вымываются, благодаря чему сосуды оказываются эластичными и обеспечивают хорошее кровоснабжение тканей и органов — это является важным фактором стабилизации артериального давления. Уже доказано, что полноценная двигательная активность активирует 
антисвертывающую систему крови, что препятствует формированию внутрисосудистых тромбов, в том числе и инфаркта миокарда.

В сердце под влиянием малоинтенсивных упражнений улучшается капилляризация, то есть на единицу сечения миокарда притекает больше крови, что не только обеспечивает лучшее энергоснабжение работы сердца, но и предупреждает возникновение в нем ишемических явлений и инфаркта миокарда. В нем улучшается течение обменных процессов, и активизируются дыхательные ферменты, нормализуется соотношения ионов калия и натрия, обеспечивающее улучшение сократительной функции сердца. При сочетании аэробных упражнений с кратковременными (в зависимости от возраста - от 20 секунд до 2-3 минут) анаэробными или аэробно-анаэробными ускорениями происходит постепенное возрастание производительности сердца, в частности, ударного объема (объема крови, выбрасываемого сердцем за одно сокращение). В этом случае в покое сердце работает очень экономично (частота сокращений снижается до 50-40 и ниже в минуту), а при выполнении напряженной работы его производительность у физкультурника оказывается гораздо выше, чем у нетренированного (так, во время работы у первого сердце может перекачать до 25-30 литров крови в минуту, а у второго - лишь 15-18 литров) [10].

Важными факторами оптимизации кровообращения являются «мышечный насос» и «периферические мышечные сердца». Первый из них заключается в том, что сокращающиеся при работе скелетные мышцы сдавливают венозные стволы (особенно в нижних конечностях), что при наличии в них клапанов способствует продавливанию крови к сердцу. Вторые же реализуются высокочастотной вибрацией артерий среднего и малого калибра, также осуществляющих продвижение крови, но теперь к капиллярам, а оттуда — по венам. Важно, что после мышечной работы 
активность вибрации сохраняется в течение нескольких часов, а при гиподинамии оказывается очень вялой.

Использование циклических упражнений преимущественно аэробного характера благоприятно сказывается и на состоянии дыхательного аппарата. Прежде всего, следует отметить тренировку дыхательных мышц, особенно мышц вдоха, сила которых заметно возрастает. Растет и эластичность легких, и просвет дыхательных путей. Тренировка обеспечивает рост жизненной емкости легких (ЖЕЛ) и эффективности газообмена (O2 и $\mathrm{CO} 2)$ между альвеолами и кровью капилляров. В покое потребление О2, частота дыхания и объем вентилируемого через легкие воздуха у тренированного ниже, чем у нетренированного, а при напряженной работе - заметно выше. Важным эффектом физической тренировки является то, что умеренная динамическая нагрузка дает лучшее расправление легочной ткани, более равномерный кровоток в ней, а активный газообмен предупреждает развитие застойных явлений, провоцирующих возникновение пневмоний.

Таким образом, «запас прочности» между покоем и максимальной производительностью для сердечнососудистой и дыхательной систем у занимающихся физической культурой заметно выше, чем у не занимающихся [3].

Центральная нервная система. Для поддержания хорошего состояния ЦНС требуется использование широкого арсенала средств.

Сила нервных процессов воспитывается через упражнения силового и скоростно-силового характера (работа с тяжестями, гимнастические упражнения, метания, прыжки), требующие максимальной концентрации возбудительного процесса в короткие периоды времени. При этом возрастают частота и амплитуда импульсации мотонейронов спинного мозга, что обеспечивает внутримышечную координацию и включение в работу наибольшего количества двигательных единиц. Адекватный же 
выбор «нужных» для осуществления данного движения мышц и выключения «ненужных» осуществляется за счет сложного реципрокного (взаимного) согласования возбуждения и торможения, что обеспечивает так называемую межмышечную координацию. Таким образом, благодаря силовым и скоростно-силовым упражнениям происходит совершенствование основных показателей функционирования ЦНС уравновешенности, силы и подвижности нервных процессов. Аналогичным действием обладают подвижные и спортивные игры, закаливание и другие интенсивные средства. Для поддержания оптимального состояния ЦНС эффективными оказываются упражнения на выносливость - циклические малоинтенсивные. Их влияние многозначно. Так, под влиянием физической тренировки открываются закрытые и увеличивается просвет функционирующих капилляров в ЦНС (что особенно важно - в наибольшей степени это происходит в лобных долях коры головного мозга; возможно, именно этим можно объяснить появляющееся при физических нагрузках чувство удовольствия). Кроме того, продолжение работы в условиях нарастающего утомления требует проявления соответствующей силы нервных процессов. Следует отметить то обстоятельство, что при выполнении такой нагрузки происходит разрушение в ЦНС и в мышцах гормонов стресса - это особенно важно в условиях исключительно высокой плотности информации, которую должен воспринять и переработать современный человек.

Опорно-двигательный аппарат. В зависимости от поставленных конкретных задач достижения высокого уровня состояния этой системы и выбор средств оказывается специфичным. Так, для получения силового эффекта следует преимущественно использовать упражнения силового характера с отягощениями, достигающими 70-90\% от предельно возможных. Эти же упражнения вместе со скоростно-силовыми, когда отягощение достигает 30-50\%, способствуют не только накапливанию в 
мышцах энергетического потенциала, но и укреплению костей. В то же время в обеспечении хорошего состояния суставов необходимо решение двух задач:

1. поддержания адекватной трофики (тканевого питания) внутрисуставных структур, для чего наилучшими средствами являются упражнения в условиях разгрузки самого сустава (или, по крайней мере, без отягощений) с многократными повторениями - велосипед для коленных суставов, в положении лежа или в воде для суставов позвоночника и т.д.;

2. достижение прочности мягких тканей, укрепляющих сустав (связки, мышцы, сухожилия) - упражнения силового и скоростно-силового характера, но, по возможности, в исходном положении, исключающем вертикальные нагрузки (например, лежа, в висе, коленно-кистевое положение и т.д.) [19].

Помимо указанных функциональных систем, где эффекты физической тренировки очевидны, следует упомянуть еще некоторые. Так, правильно организованные физические упражнения нормализуют деятельность желудочно-кишечного тракта: желудочное и кишечное сокоотделение, активность пищеварительных ферментов, моторную активность и т.д. Регулярные занятия физической культурой, сопровождаемые потоотделением, не только совершенствуют терморегуляцию, но и обеспечивают систематический вывод из организма образовавшихся в процессе жизнедеятельности шлаковых веществ. Наконец, доказана прямая зависимость между состоянием физической работоспособности и другими ее формами, в частности, умственной, и устойчивостью психических функций.

Таким образом, правильно подобранные и оптимально спланированные физические нагрузки способствуют поддержанию на высоком функциональном уровне всех физиологических систем, 
обеспечивают достаточную общую и специальную работоспособность, делают жизнедеятельность человека более экономичной и, наконец, предупреждают развитие в организме многих патологических процессов.

\subsection{2. Место физической культуры в поддержании и укреплении здоровья взрослых}

Набор физических упражнений и режим их использования должен быть сугубо индивидуальным для каждого человека в зависимости от его пола, возраста, профессии, семейного положения, режима работы, типа конституции, имеющегося двигательного опыта и т.д. Тем не менее, есть некоторые общие подходы, которые необходимо учитывать в этом вопросе. Укажем на те, которые относятся к физической культуре взрослых людей.

Для любого человека обязательным условием является утренняя гигиеническая гимнастика. Следует отметить, что это средство двигательной активности должно соответствовать индивидуальным особенностям человека.

При определении набора физических упражнений, которые человек должен и может включить в свой двигательный арсенал, следует исходить прежде всего из того, какие нарушения здоровья и патологические состояния наиболее часто встречаются у современного человека и насколько они связаны с его образом жизни. В последние $30-40$ лет удалось найти эффективные средства борьбы с инфекциями, на долю которых ранее приходилась подавляющая часть смертности. Теперь на первый план выдвинулись те заболевания, которые преимущественно связаны с гиподинамией, избыточным и неправильным питанием и чрезмерными психическими нагрузками. Все эти факторы риска могут активно устранены целенаправленной и умело организованной двигательной активностью [12]. 
Для современного человека особую опасность представляют сердечнососудистые и онкологические заболевания, сахарный диабет, перенапряжение психики и нарушения в опорно-двигательном аппарате. Из них лишь в отношении онкологии нет убедительных данных, которые бы свидетельствовали о профилактической и лечебной роли физической культуры. Во всех же остальных случаях можно говорить о высокой эффективности последних. Анализ имеющегося опыта позволяет предложить следующий набор обязательных средств физической культуры, которые могли бы в значительной степени предупредить указанные заболевания:

I. Упражнения аэробного циклического характера, обеспечивают поддержание нормального уровня функционирования сердечнососудистой, дыхательной и нервной систем, терморегуляции, обмена веществ и т.д.;

II. Гимнастические упражнения, выполняемые с целью поддержания хорошего состояния позвоночника (с акцентом на шейный и поясничный отделы, где наиболее часто встречаются нарушения); для суставов плечевых, тазобедренных, коленных и голеностопных; кровообращения мозга (упражнения для мимических мышц лица и мыши шеи, а также усиливающие приток крови к мозгу); для деятельности желудочно-кишечного тракта (на мышцы брюшного пресса); для мочеполовой системы (на мышцы области, промежности).

Закаливающие процедуры, позволяющие поддерживать высокий уровень иммунитета.

В двигательном режиме взрослого количество средств физической культуры должно быть не менее 4-5, с возрастом же их набор может уменьшиться до 2-3.

В жизни человека двигательная активность должна занимать то место, которое согласуется с условиями его профессиональной, бытовой и прочих сторон жизнедеятельности. Занятия физкультурой можно 
проводить в зависимости от условий работы и типологических особенностей человека и утром, и днем, и вечером под постоянным врачебно-педагогическим контролем, с учетом текущего состояния организма. Периодичность занятий физкультурой и длительность каждого из них связаны обратной зависимостью, однако тренирующий эффект при частоте занятий менее трех раз в неделю и короче 30 минут оказывается низким. Оптимальным режимом следует считать для взрослого человека 3-5 раз в неделю при длительности 90 (при пяти занятиях) и 120 (при трех занятиях в неделю) минут.

Закаливающие процедуры, позволяющие поддерживать высокий уровень иммунитета.

В двигательном режиме взрослого количество средств физической культуры должно быть не менее 4-5, с возрастом же их набор может уменьшиться до 2-3.

В жизни человека двигательная активность должна занимать то место, которое согласуется с условиями его профессиональной, бытовой и прочих сторон жизнедеятельности. Занятия физкультурой можно проводить в зависимости от условий работы и типологических особенностей человека и утром, и днем, и вечером под постоянным врачебно-педагогическим контролем, с учетом текущего состояния организма. Периодичность занятий физкультурой и длительность каждого из них связаны обратной зависимостью, однако тренирующий эффект при частоте занятий менее трех раз в неделю и короче 30 минут оказывается низким. Оптимальным режимом следует считать для взрослого человека 3-5 раз в неделю при длительности 90 (при пяти занятиях) и 120 (при трех занятиях в неделю) минут [8].

Исключительно важное значение имеет рациональное использование физических упражнений в режиме рабочего дня, что позволяет решить целый ряд задач: 
1. Выполняемый до начала работы специально подобранный комплекс упражнений способствует укорочению времени врабатывания и более быстрому достижению максимальной работоспособности. В частности, для работников умственного труда в таком комплексе должны быть упражнения на быстрое переключение внимания, координацию движений и т.д.

2. Обычно выполнение профессиональных обязанностей сопряжено с длительным поддержанием вынужденных статических поз (учащиеся, станочники, ученые и т.д.). В этом случае прослеживается целый ряд неблагоприятных для организма последствий в виде нарушений осанки, кровообращения, дыхания, зрения и других, поэтому физические упражнения могут способствовать включению в активность неработающих мышц, коррекции осанки, восстановлению кровообращения и дыхания, нормализации зрений и устранению прочих последствий длительного поддержания вынужденной позы.

3. В условиях все большей специализации в производстве в целях обеспечения высокой эффективности труда рабочим часто приходится ограничиваться выполнением довольно узкого круга движений, которые доводятся до высокой степени автоматизма. В этом случае необходимость в произвольном сознательном контроле постепенно уменьшается, в связи, с чем монотонная механическая работа довольно быстро ведет к возникновению запредельного торможения. Нетрудно представить, сколь опасны, могут быть последствия возникающей при этом сонливости.

4. В тех видах профессиональной деятельности, которые связаны с большими и плотными потоками информации, требуются быстрая реакция и оперативный поиск правильного решения. Выполнение этих требований возможно лишь в условиях апологического стресса, способствующего мобилизации возможностей организма. Однако подобный стресс сопровождается повышением мышечного тонуса, нарастание которого еще 
боне усугубляет стресс. Снятие мышечного гипертонуса через расслабление соответствующих мышц обеспечивает нормализацию состояния ЦНС. Кроме того, используемые в этом случае физические упражнения улучшают эмоциональное состояние работника.

5. Физические упражнения, рационально применяемые в режиме рабочего дня, способствуют более быстрому повышению работоспособности и росту производительности труда. Регулярные занятия физической культурой увеличивают профессиональную работоспособность на 10-14\% [5].

Выдающийся физиолог И. М. Сеченов еще в середине XIX в. ввел понятие «активный отдых». Суть его заключается в том, что при наступающем утомлении переключение на другой вид деятельности обеспечивает более быстрое восстановление работоспособности утомленных нервных центров, чем в условиях пассивного отдыха. Например, при умственном утомлении выполнение сходных по структуре физических упражнений, отличающихся эмоциональностью (в частности танцы), способствует более быстрому восстановлению, чем пассивный отдых.

Отдельного разговора заслуживает вопрос о физической культуре работников умственного труда. Это обусловлено спецификой влияния этого вида профессиональной деятельности на организм человека. В частности, умственный труд характеризуется следующими особенностями:

$>$ напряжение мыслительных процессов с высокой динамичностью и силой возбудительно-тормозных процессов в ЦНС;

$>$ неравномерность нагрузки, необходимость принимать срочные и нестандартные решения, возможность возникновения конфликтных ситуаций;

не регламентированный график, периодически возникающие возрастания степени нервно-эмоционального напряжения; 
$>$ напряжение отдельных анализаторов и внимания;

сложность взаимоотношений с окружающими;

большой и плотный поток информации, напряжение памяти, внимания, восприятия и воспроизведения новой информации;

низкая двигательная активность.

При мыслительной работе происходят сосудистые реакции, противоположные тем, которые бывают при мышечной работе: кровенаполнение сосудов мозга, сужение периферийных сосудов конечностей, расширение сосудов внутренних органов и т.д. Когда же такой труд сопровождается нервно-эмоциональным напряжением, происходит резкая активизация кровообращения с повышением частоты пульса, артериального давления, наступают изменения в ритме и частоте дыхания, снижается насыщение крови кислородом, нарушается терморегуляция и отмечаются многие другие неблагоприятные изменения, нарушающие состояние организма. Специфика умственного труда заключается и в том, что после прекращения работы мысли о ней, «рабочая доминанта», сохраняются еще довольно долго. В результате оказывается, что неправильно организованная умственная работа быстро приводит к функциональному утомлению из-за запредельного торможения в головном мозгу.

При нерационально организованной профессиональной умственной деятельности могут возникать функциональные, а затем и морфологические нарушения в организме, основной причиной которых является малоподвижность. Наиболее часто среди таких отклонений в состоянии здоровья встречаются склеротические изменения сосудов, появление гипотонии (у молодых) или гипертонии (у пожилых), возникновение неврозов, ослабление дыхательной функции, атония кишечника, нарушения обмена веществ и т.д. 
При умственной деятельности происходит напряжение мышц лица, шеи и плечевого пояса, так как их активность тесно связана с нервными центрами, управляющими вниманием, эмоциями. В этих условиях длительная импульсация от напряженных мышц создает утомление в соответствующих участках ЦНС, и работоспособность снижается. Естественной мерой предупреждения этого явления могут быть активные движения, освобождающие мышцы от излишнего напряжения [20].

$\mathrm{He}$ менее важно для поддержания высокой умственной работоспособности имеет состояние мускулатуры, так как между ними существует прямая зависимость.

Оптимально подобранная мышечная нагрузка повышает общий эмоциональный тонус, создавая устойчивое настроение, который служит благоприятным фоном для умственной деятельности и предупреждает раннее развитие утомления. Физические упражнения оказывают на умственную работоспособность либо непосредственное благоприятное влияние по механизмам активного отдыха, либо отдаленное спустя некоторое время, либо в виде кумулятивного (накапливающего) эффекта.

В разработке оптимальных режимов двигательной активности для занимающихся преимущественно умственным трудом следует учитывать возраст, пол, уровень здоровья, характер деятельности, образ жизни, генетические особенности и т.д. каждого отдельного человека, то есть такой режим должен быть сугубо индивидуальным. Тем не менее, есть определенные общие подходы к разработке двигательных режимов. Так, упражнения динамического циклического характера оказываются более эффективными для поддержания умственной работоспособности, чем статические. Физическая активность может быть реализована как в виде выполнения кратковременных комплексов несколько раз в течение дня, так и в одном продолжительном занятии. Утренняя зарядка, легкие кратковременные упражнения на ловкость и внимание перед началом 
работы ускоряют врабатывание в умственную деятельность через повышение возбудимости и подвижности нервных процессов в ЦНС. В самостоятельных занятиях помимо средств общего воздействия (повышающих физическую подготовленность, а через нее - и умственную работоспособность) следует использовать упражнения направленного и специального действия для данного человека и выполняемого им вида профессиональной деятельности. К ним следует отнести упражнения для мышц зрительного аппарата, для релаксации, коррекции позы, дыхательные и др [21].

К формам организации двигательной активности работников умственного труда можно отнести:

1. Утреннюю гигиеническую гимнастику;

2. Вводную гимнастику непосредственно перед началом рабочего дня. Обычно выполняются 5-6 упражнений на координацию движений и произвольное напряжение мышц верхних конечностей. Длительность комплекса 3-5 минут.

3. Физкультурные паузы ставят целью компенсировать неблагоприятные влияния условий работы и проводятся приблизительно в середине первой и второй половине рабочего дня. В комплекс из 5-8 упражнений включают движения, корригирующие осанку, активизирующие деятельность внутренних органов, на крупные мышечные группы, стимулирующие мозговой кровоток и т.д. Продолжительность -10-15 минут.

4. Физкультминутки призваны оказать местное воздействие на наиболее утомленные части тела и группы мышц и проводятся непосредственно на рабочем месте через каждые 40-60 минут в течение 2-3 минут. Это могут быть вращения головой, плечами, смена позы, диафрагмальное дыхание, для мышц зрительного аппарата, кистей др. 
5. В обеденный перерыв до приема пищи необходимо сменить обстановку, походить, а после приема пищи выполнить релаксирующие упражнения. Непосредственно перед возобновлением работы можно выполнить несколько легких упражнений типа вводной гимнастики.

В вечернее время правильно организованная двигательная активность (например, прогулка) будет способствовать хорошему качеству последующего сна и адекватному восстановлению мышечной работоспособности человека, связанного с умственной профессиональной деятельностью.

Для работников умственного труда важное значение имеет рациональная организация жизнедеятельности в выходные дни. В этом отношении следует отметить два обстоятельства:

1. Смена обстановки позволяет снять очаги застойного торможения в ЦНС, формирующиеся в течение рабочей недели.

2. Насыщение образа жизни в эти дни двигательной деятельностью играет не только роль активного отдыха, но и способствует повышению физической подготовленности и физического здоровья человека [9].

Подводя итог рассмотренному материалу, необходимо отметить, что полноценная двигательная активность является неотъемлемой частью здорового образа жизни, оказывающей влияние практически на все стороны жизнедеятельности человека как в профессиональной,, так и в бытовой, досуговой и других сторонах его жизни.

\section{Контрольные вопросы}

1. Что предполагает здоровый образ жизни?

2. Что такое здоровье человека (по определению, принятому Всемирной организацией здравоохранения)?

3. Какие различают группы факторов риска, влияющих на здоровье человека? 
4. Какой показатель является наиболее интегральным показателем физического здоровья здорового человека?

5. Что такое должная величина МПК (ДМПК)?

6. Что такое оздоровительная тренировка?

7. Какие физические упражнения наиболее эффективны в оздоровительной тренировке: ациклические или циклические?

8. Какой метод является наиболее эффективным в оздоровительной тренировке?

9. Какой должна быть мощность тренировочной нагрузки (в \% к максимальному уровню физической работоспособности) в оздоровительной тренировке?

10. Какие основные функции питания?

Тема 3. Основы методики самостоятельных занятий физическими упражнениями. Самоконтроль при занятиях физической культурой и спортом

\section{План:}

3.1. Мотивация и целенаправленность самостоятельных занятий.

3.2. Формы и содержание самостоятельных занятий.

3.3. Особенности самостоятельных занятий для женщин.

3.4. Управление самостоятельными занятиями.

3.5. Энергозатраты при физической нагрузке разной интенсивности.

3.6. Гигиена самостоятельных занятий.

3.8. Профилактика травматизма.

3.9. Самоконтроль при занятиях физической культурой и спортом. 


\section{1. Мотивация и целенаправленность самостоятельных занятий}

Приобщение студенческой молодежи к физической культуре важное слагаемое в формировании здорового образа жизни. Наряду с широким развитием и дальнейшим совершенствованием организованных форм занятий по физической культуре решающее значение имеют самостоятельные занятия физическими упражнениями.

Здоровье и учеба студентов взаимосвязаны и взаимообусловлены.

Чем крепче здоровье студента, тем продуктивнее обучение, иначе конечная цель обучения утрачивает подлинный смысл и ценность. Чтобы студенты успешно адаптировались к условиям обучения в вузе, сохранили и укрепили здоровье за время обучения, необходимы здоровый образ жизни и регулярная оптимальная двигательная активность [28].

Современные сложные условия жизни диктуют более высокие требования к биологическим и социальным возможностям человека. Всестороннее развитие физических способностей людей с помощью организованной двигательной активности (физической тренировки) помогает сосредоточить все внутренние ресурсы организма на достижении поставленной цели, повышает работоспособность, укрепляет здоровье, позволяет в рамках короткого рабочего дня выполнить все намеченные дела.

Мышцы составляют 40-45\% массы тела человека, организм которого очень чутко реагирует как на снижение двигательной активности, так и на тяжелые, непосильные физические нагрузки.

Систематическое, соответствующее полу, возрасту и состоянию здоровья, использование физических нагрузок - один из обязательных факторов здорового режима жизни. Физические нагрузки представляют собой сочетание разнообразных двигательных действий, выполняемых в повседневной жизни, а также организованных или самостоятельных 
занятий физической культурой и спортом, объединенных термином «двигательная активность». У большого числа людей, занимающихся умственной деятельностью, наблюдается ограничение двигательной активности.

Специалист, завершивший обучение по дисциплине «Физическая культура», должен обнаружить мотивационно-ценностное отношение к физической культуре, сформированную потребность в регулярных занятиях физическими упражнениями и спортом, в физическом сам совершенствовании.

Отношение студентов к физической культуре и спорту - одна из актуальных социально-педагогических проблем.

Многочисленные данные науки и практики свидетельствуют о том, что физкультурно-спортивная деятельность еще не стала для студентов насущной потребностью, не превратилась в интерес личности. Реальное внедрение среди студентов самостоятельных занятий физическими упражнениями недостаточно.

Существуют объективные и субъективные факторы, определяющие потребности, интересы и мотивы включения студентов в активную физкультурно-спортивную деятельность.

К объективным факторам относятся: состояние материальной, спортивной базы, направленность учебного процесса по физической культуре и содержание занятий, уровень требований учебной программы, личность преподавателя, состояние здоровья занимающихся, частота проведения занятий, их продолжительность и эмоциональная окраска.

В вузах задачу формировании мотивов, переходящих в потребность физических упражнений, призваны решать лекции по физической культуре, практические занятия, массовые, оздоровительно-спортивные мероприятия [31]. 
Если мотивы сформировались, то определяется цель занятий, ею может быть: активный отдых, укрепление здоровья, повышение уровня физического развития и физической подготовленности, выполнение различных тестов, достижение спортивных результатов.

\section{2. Формы и содержание самостоятельных занятий}

После определения цели подбираются направление использования средств физической культуры, а также формы самостоятельных занятий физическими упражнениями.

Конкретные направления и организационные формы использования самостоятельных занятий зависят от пола, возраста, состояния здоровья, уровня физической и спортивной подготовленности занимающихся. Можно выделить гигиеническое, оздоровительно-рекреативное (рекреация - восстановление), обще-подготовительное, спортивное, профессионально-прикладное и лечебное направления.

Формы самостоятельных занятий физическими упражнениями и спортом определяются их целями и задачами. Существует три формы самостоятельных занятий: утренняя гигиеническая гимнастика, упражнения в течение учебного дня, самостоятельные тренировочные занятия.

Утренняя гигиеническая гимнастика включается в распорядок дня в утренние часы после пробуждения от сна.

В комплексы утренней гигиенической гимнастики следует включать упражнения для всех групп мышц, упражнения на гибкость и дыхательные упражнения. Не рекомендуется выполнять упражнения статического характера, со значительными отягощениями, на выносливость (например, длительный бег до утомления). Можно включать упражнения со скакалкой, эспандером и резиновым жгутом, с мячом и т.д. 
При составлении комплексов и их выполнении рекомендуется физическую нагрузку на организм повышать постепенно, с максимумом в середине и во второй половине комплекса. К окончанию выполнения комплекса упражнений нагрузка снижается, и организм приводится в сравнительно спокойное состояние.

Утренняя гигиеническая гимнастика должна сочетаться с самомассажем и закаливанием организма. Сразу же после выполнения комплекса утренней гимнастики рекомендуется сделать самомассаж основных мышечных групп ног, туловища и рук (5-7 мин.) и выполнить водные процедуры с учетом правил и принципов закаливания.

Упражнения в течение учебного дня выполняются в перерывах между учебными или самостоятельными занятиями. Такие упражнения предупреждают наступающее утомление, способствуют поддержанию высокой работоспособности в течение длительного времени без перенапряжения. Выполнение физических упражнений в течение 10-15 мин через каждые 1-1,5 часа работы оказывают вдвое больший стимулирующий эффект на улучшение работоспособности, чем пассивный отдых в два раза большей продолжительности.

Физические упражнения нужно проводить в хорошо проветренных помещениях. Очень полезно выполнять упражнения на открытом воздухе.

Самостоятельные тренировочные занятия можно проводить индивидуально или в группе из 3-5 человек и более. Групповая тренировка более эффективна, чем индивидуальная. Самостоятельные индивидуальные занятия на местности или в лесу вне населенных пунктов во избежание несчастных случаев не допускаются. Выезд или выход для тренировок за пределы населенного пункта может проводиться группами из 3-5 человек и более. При этом должны быть приняты все необходимые меры предосторожности по профилактике спортивных травм, обморожения и т.д. 
He допускается также отставание от группы отдельных занимающихся.

Заниматься рекомендуется 2-7 раз в неделю по 1-1,5 часа. Заниматься менее 2 раз в неделю нецелесообразно, так как это не способствует повышению уровня тренированности организма. Лучшее время для тренировок - вторая половина дня, через 2-3 часа после обеда. Можно тренироваться и в другое время, но не раныше, чем через 2 часа после приема пищи и не позднее, чем за час до приема пищи или до отхода ко сну. Не рекомендуется тренироваться утром сразу после сна натощак (в это время необходимо выполнять гигиеническую гимнастику). Тренировочные занятия должны носить комплексный характер, т.е. способствовать развитию всего множества физических качеств, а также укреплять здоровье и повышать общую работоспособность организма. Специализированный характер занятий, т.е. занятия избранным видам спорта, допускается только для квалифицированных спортсменов.

Самостоятельные тренировочные занятия проводятся по общепринятой структуре.

Наиболее распространенные средства самостоятельных занятий в вузах - это ходьба и бег, кросс, дорожки здоровья, плавание, ходьба и бег на лыжах, велосипедные прогулки, ритмическая гимнастика, атлетическая гимнастика, спортивные и подвижные игры, спортивное ориентирование, туристские походы, занятия на тренажерах [29].

Ходьба и бег. Наиболее доступными и полезными средствами физической тренировки являются ходьба и бег на открытом воздухе в условиях лесопарка.

Ходьба - естественный вид движений, в котором участвует большинство мышц, связок, суставов. Ходьба улучшает обмен веществ в организме и активизирует деятельность сердечнососудистой, дыхательной и других систем организма. Интенсивность физической нагрузки при 
ходьбе легко регулируется в соответствии с состоянием здоровья, физической подготовленностью и тренированностью организма. Эффективность воздействия ходьбы на организм человека зависит от длины шага, скорости ходьбы и ее продолжительности.

Перед тренировкой необходимо сделать короткую разминку.

При определении физической нагрузки следует учитывать ЧСС (пульс) (табл. 2). Пульс подсчитывается в процессе кратковременных остановок во время ходьбы и сразу после окончания тренировки.

Таблица 2 - Определение оптимальной интенсивности ходьбы по ЧСС (В.С.Матяжов), уд/мин

\begin{tabular}{|c|c|c|c|c|c|}
\hline \multirow[t]{2}{*}{ Время ходьбы, мин. } & \multicolumn{5}{|c|}{ ЧСС для мужчин (для женщин на 6 уд/мин. более) } \\
\hline & до 30 лет & 30-39 лет & 40-49 лет & 50-59 лет & 60-69 лет \\
\hline 60 & $145-155$ & $135-145$ & $125-135$ & $110-120$ & $100-110$ \\
\hline 70 & $140-250$ & $130-140$ & $120-130$ & $105-115$ & $95-105$ \\
\hline 80 & $135-145$ & $125-135$ & $115-125$ & $100-110$ & $90-100$ \\
\hline 90 & $130-140$ & $120-130$ & $110-120$ & $95-105$ & $85-95$ \\
\hline
\end{tabular}

Заканчивая тренировочную ходьбу, надо постепенно снизить скорость, чтобы в последние 5-10 мин. ходьбы ЧСС была на 10-15 уд/мин меньше указанной в таблице. Через 8-10 мин. после окончания тренировки (после отдыха) частота пульса должна вернуться к исходному уровню, который был до тренировки. Увеличение дистанции и скорости ходьбы должно нарастать постепенно.

Чередование ходьбы с бегом. При хорошем самочувствии и свободном выполнении тренировочных нагрузок по ходьбе можно 
переходить к чередованию бега с ходьбой, что обеспечивает постепенное нарастание нагрузки и дает возможность контролировать ее в строгом соответствии со своими индивидуальными возможностями.

После выполнения бега в чередовании с ходьбой и при наличии хорошего самочувствия можно переходить к непрерывному бегу.

Б е г - наиболее эффективное средство укрепления здоровья и повышения уровня физической тренированности.

Мудрая природа в ходе эволюции запрограммировала для организма человека высокую надежность и прочность, рассчитанную, по оценкам специалистов, не менее чем на 120-150 лет здоровой жизни. Однако реализовать эту заманчивую программу не так-то просто. Этому мешают чаще всего нежелательные отклонения, происходящие в сердечно-сосудистой системе. Существует немало средств укрепления сердечно-сосудистой системы, и на ведущее место среди них все увереннее выдвигается оздоровительный бег [16].

При систематической тренировке в дальнейшем мужчины могут довести время непрерывного бега до 50-70 мин. (8-10 км) и более, женщины - до 40-50 мин. (5-6 км) и более.

Можно рекомендовать следующие режимы интенсивности при беге по самочувствию и ЧСС. Выбор продолжительности бега зависит от подготовленности занимающихся студентов.

Режим 1. Зона комфортная. Используется как основной режим для начинающих бегунов со стажем до одного года. Бегуну сопутствует ощущение приятного тепла, ноги работают легко и свободно, дыхание осуществляется через нос, бегун без труда поддерживает выбранную скорость, ему ничто не мешает, возникает желание бежать быстрее. Спортсмены используют этот режим, чтобы восстановиться после напряженных тренировок. ЧСС сразу после бега 20-22, через 1 мин. 13-15 ударов за 10 секунд. 
Режим 2. Зона комфорта и малых усилий. Для бегунов со стажем 2 года.

Бегун ощущает приятное тепло, ноги продолжают работать легко и свободно, дыхание глубокое смешанное через нос и рот, мешает легкая усталость, скорость бега сохраняется с небольшим усилием.

ЧСС сразу после бега 24-26, через 1 минуту 18-20 ударов за 10 секунд.

Режим 3. Зона напряженной тренировки. Для бегунов со стажем 3 года, для спортсменов как тренировочный режим. Бегуну жарко, несколько тяжелеют ноги, особенно бедра, при дыхании не хватает воздуха на вдохе, исчезла легкость, трудно удерживать темп, скорость сохраняется напряжением воли. ЧСС сразу после бега 27-29, через 1 минуту 23-26 ударов за 10 секунд.

Режим 4. Зона соревновательная. Для бегунов, участвующих в соревнованиях по бегу. Бегуну очень жарко, ноги тяжелеют и «вязнут», дыхание напряженное, с большой частотой, мешает излишнее напряжение мышц шеи, рук, ног, бег выполняется с трудом, несмотря на усилия, скорость бега на финише падает. ЧСС сразу после бега 30-35, через 1 минуту 27-29 ударов за 10 секунд.

Основной, если не единственный метод тренировки в оздоровительном беге -равномерный (или равномерно ускоренный) метод, развитие которого связано с именем А. Лидьярда. Его суть заключается в том, что вся дистанция проходится в ровном темпе с постоянной скоростью.

Начинающие бегуны в качестве подготовительного средства могут применять чередование ходьбы и бега. Например: 50 м бега и 150 м ходьбы, затем 100 м бега и 100 м ходьбы. Отрезки бега должны увеличиваться непроизвольно, естественным путем, до тех пор, пока бег не станет непрерывным. 
Из всего богатого арсенала тренировочных средств бегунов на средние и длинные дистанции для любителей оздоровительного бега подходят только три.

1. Легкий равномерный бег от 20 до 30 минут при пульсе 120-130 ударов в минуту. Для начинающих бегунов это основное и единственное средство тренировки. Подготовленные бегуны используют его в разгрузочные дни в качестве облегченной тренировки, способствующей восстановлению.

2. Длительный, равномерный бег по относительно ровной трассе от 60 до 120 минут при пульсе 132-144 уд/мин. Применяется для развития и поддержания общей выносливости.

3. Кроссовый бег от 30 до 90 минут при пульсе 144-156 уд/мин. 2-3 раза в неделю. Применяется для развития выносливости только хорошо подготовленными бегунами.

Занятие начинается с разминки продолжительностью 10-15 мин.

Она необходима для того, чтобы «разогреть» мышцы, подготовить организм к предстоящей нагрузке, предотвратить травмы.

Начиная бег, важно соблюдать самое главное условие - темп бега должен быть невысоким и равномерным, бег доставляет удовольствие, «мышечную радость». Если нагрузка слишком высока и быстро наступает утомление, следует снижать темп или несколько сокращать его продолжительность [9].

Плавание. Плаванием занимаются в летние каникулярные периоды в открытых водоемах, а в остальное время учебного года - в закрытых или открытых бассейнах с подогревом воды.

В начальный период занятий необходимо постепенно увеличивать время пребывания в воде от 10-15 до 30-45 мин. и добиваться, чтобы преодолевать за это время без остановок в первые пять дней 600-700 м, во вторые - 700-800, а затем 1000-1200 м. Для тех, кто плавает плохо, сначала 
следует проплывать дистанцию 25,50 или 100 м., но повторять ее 8-10 раз. По мере овладения техникой плавания и воспитания выносливости переходить к преодолению указанных дистанций.

Оздоровительное плавание проводится равномерно с умеренной интенсивностью. Частота сердечных сокращений сразу после проплывания дистанций для возраста 17-30 лет должна быть в пределах 120-150 уд/мин.

При занятиях плаванием необходимо соблюдать следующие правила безопасности: занятия в открытом водоеме проводить группой из 3-5 человек и только на проверенном месте глубиной не более 1 м 20 см.; заниматься следует не ранее чем через 1,5-2 ч. после приема пищи; запрещается заниматься плаванием при плохом самочувствии, повышенной температуре, простудных и желудочно-кишечных заболеваний; лучшее время для занятий плаванием - с 10-11 до 13 ч., в жаркую погоду можно заниматься второй раз с 16 до 18 ч.

Ходьба и бег на лыжах. Индивидуальные самостоятельные занятия можно проводить только на стадионах или в парках в черте населенных пунктов; занятия на местности, отдаленной от населенных пунктов или в лесу во избежание несчастных случаев не допускаются.

Выезд или выход на тренировки за пределы населенного пункта должен осуществляться группами в 3-5 человек и более. При этом должны быть приняты все необходимые меры предосторожности по профилактике спортивных травм, обмороженной и т.д. Отдельные спортсмены не должны отставать от группы.

Полезно заниматься на лыжах каждый день хотя бы по одному часу. Минимальное количество занятий, которое дает оздоровительный эффект и повышает тренированность организма, три раза в неделю по 1-1,5 ч. и более при умеренной интенсивности.

Велосипед. Езда на велосипеде, благодаря постоянно меняющимся внешним условиям, является эмоциональным видом физических 
упражнений, благоприятно воздействующим на нервную систему. Ритмичное педалирование (вращение педалей) увеличивает и одновременно облегчает приток крови к сердцу, что укрепляет сердечную мышцу и развивает легкие.

Перед каждым выездом исправность машины тщательно проверяется.

При этом следует убедиться, что шины достаточно накачаны; колеса, педали и кареточная ось вращаются свободно; цепь не повреждена и имеет правильное натяжение; седло прочно закреплено. Особенно тщательно проверяется исправность тормозов.

Езда на велосипеде хорошо дозируется по темпу и длине дистанции.

Хорошо иметь велосипедный спидометр, с помощью которого можно определить скорость передвижения и расстояние.

Ритмическая гимнастика (аэробные танцы). Ритмическая гимнастика - это комплексы несложных, общеразвивающих упражнений, которые выполняются, как правило, без пауз для отдыха, в быстром темпе, определяемом современной музыкой. $\mathrm{B}$ комплексы включаются упражнения для всех основных групп мышц и для всех частей тела: маховые и круговые движения руками, ногами; наклоны и повороты туловища и головы; приседания и выпады; простые комбинации этих движений, а также упражнения в упорах, в положении лежа. Все эти упражнения сочетаются с прыжками на двух и на одной ноге, с бегом на месте и небольшим продвижением во всех направленных, танцевальными элементами.

Благодаря быстрому темпу и продолжительности занятий от 10-15 до 45-60 мин. ритмическая гимнастика, кроме воздействия на опорно-двигательный аппарат, оказывает большое влияние на сердечно-сосудистую и дыхательную системы. По воздействию на организм ее можно сравнить с такими циклическими упражнениями, как 
бег, бег на лыжах, езда на велосипеде, т.е. с видами физических упражнений, при занятиях которыми происходит заметный рост потребления мышцами кислорода. Отсюда и ее второе название -аэробика или аэробные танцы (греч. «аэро» - воздух, и «биос» - жизнь).

Атлетическая гимнастика. Атлетическая гимнастика - это система физических упражнений, развивающих силу в сочетании с разносторонней физической подготовкой. Занятия атлетической гимнастикой способствуют развитию силы, выносливости, ловкости, формируют гармоничное телосложение.

Развитие силы обеспечивается выполнением следующих специальных силовых упражнений:

$>$ упражнения с гантелями (масса 5-12 кг): наклоны, повороты, круговые движения туловищем, выжимание, приседание, опускание и поднимание гантелей в различных направлениях прямыми руками, поднимание и опускание туловища с гантелями за головой, лежа на скамейке;

упражнений с гирями (16,24,32 кг): поднимание к плечу, на грудь, одной и двумя руками, толчок и жим одной и двух гирь, рывок, бросание гири, жонглирование гирей;

упражнения с эспандером: выпрямление рук в стороны, сгибание и разгибание рук в локтевых суставах, из положения - стоя на рукоятке эспандера, вытягивание эспандера до уровня плеч;

упражнения с металлической палкой (5-12 кг): рывок различным хватом, жим - стоя, сидя, от груди, из-за головы, сгибание и выпрямление рук в локтевых суставах;

упражнения со штангой (масса подбирается индивидуально): подъем штанги к груди, на грудь, с подседом и без подседа; приседания со штангой 
на плечах, на груди, за спиной; жим штанги, лежа на наклонной плоскости, скамейке; толчок штанги, стоя, от груди, то же с подседом; повороты, наклоны, подскоки, выпрыгивания со штангой на плечах; классические соревновательные движения: рывок, толчок;

различные упражнения на тренажерах и блочных устройствах, включая упражнения в изометрическом и уступающем режимах работы мышц.

При выполнении упражнений с тяжестями и на тренажерах необходимо следить, чтобы не было задержки дыхания. Дыхание должно быть ритмичным и глубоким.

Каждое занятие следует начинать с ходьбы и медленного бега, затем переходить к гимнастическим, общеразвивающим упражнениям для всех групп мышц (разминка). После разминки выполняется комплекс атлетической гимнастики, включающего упражнения для плечевого пояса и рук, для туловища и шеи, для мышц ног и упражнения для формирования правильной осанки. В заключительной части проводятся медленный бег, ходьба, упражнения на расслабление с глубоким дыханием.

Чтобы обеспечить разностороннюю физическую и функциональную подготовку, в систему занятий необходимо включать подвижные и спортивные игры, легкоатлетические упражнения (бег, прыжки, метания), плавание, ходьбу и бег на лыжах и т.п.

Атлетическая гимнастика полезна и женщинам. С eе помощью укрепляются опорно-двигательный аппарат и мышечная система. Особенно полезны женщинам упражнения для укрепления мышц брюшного пресса и тазового дна. Используя упражнения, можно обеспечить стройное, пропорционально развитое телосложение, уменьшить или увеличить массу тела. 
Спортивные и подвижные игры имеют большое оздоровительное значение. Их отличает разнообразная двигательная деятельность и положительные эмоции, они эффективно снимают чувство усталости, тонизируют нервную систему, улучшают эмоциональное состояние, повышают умственную и физическую работоспособность. Коллективные действия в процессе игры воспитывают нравственные качества: общительность, чувство товарищества, способность жертвовать личными интересами ради интересов коллектива. Особенно полезны игры на открытом воздухе.

Подвижные игры отличаются несложными правилами, и команды для их проведения могут комплектоваться произвольно. Можно рекомендовать следующие подвижные игры: «третий лишний», «мяч по кругу», «мяч в корзину», «пионербол», «диск на льду» [24].

Спортивные игры, по сравнению с подвижными, требуют более высокого владения приемами техники конкретного вида игры и знания правил судейства, определяющих взаимоотношения и поведения играющих.

Наиболее распространенными спортивными играми в вузах являются: волейбол, баскетбол, ручной мяч, футбол, хоккей, теннис, настольный теннис, городки и др. Спортивные игры требуют специально оборудованных стандартных спортивных площадок или спортивных залов.

\section{3. Особенности самостоятельных занятий для женщин}

Организм женщины имеет анатомо-физиологические особенности, которые необходимо учитывать при проведении самостоятельных занятий физическими упражнениями или спортивной тренировки. В отличие от мужского у женского организма менее прочное строение костей, меньшее общее развитие мышц брюшного пресса, спины и тазового дна. От их 
развития зависит нормальное положение внутренних органов. Особенно важно развитие мышц тазового дна.

Одной из причин недостаточного развития этих мышц у студенток и работниц умственного труда является малоподвижный образ жизни.

При положении сидя мышцы тазового дна не противодействуют внутрибрюшному давлению и растягиваются от тяжести лежащих над ними органов. В связи с этим мышцы теряют свою эластичность и прочность, что может привести к нежелательным изменениям положения внутренних органов и ухудшению их функциональной деятельности.

Ряд характерных для организма женщины особенностей имеется и в деятельности сердечнососудистой, дыхательной, нервной и других систем.

Bce это выражается более продолжительным периодом восстановления организма после физической нагрузки, а также более быстрой потерей состояния тренированности при прекращении тренировок.

Особенности женского организма должны строго учитываться в организации, содержании, методике проведения самостоятельных занятий.

Подбор физических упражнений, их характер и интенсивность должны соответствовать физической подготовленности, возрасту, индивидуальным возможностям студенток. Необходимо исключать случаи форсирования тренировки для того, чтобы быстро достичь высоких результатов. Разминку следует проводить более тщательно и более продолжительно, чем при занятиях мужчин. Рекомендуется остерегаться резких сотрясений, мгновенных напряжений и усилий, например, при занятиях прыжками и в упражнениях с отягощением. Полезны упражнения, в положении сидя, и лежа на спине с подниманием, отведением, приведением и круговыми движениями ног, с подниманием ног и таза до положения «березка», различного рода приседания [12]. 
Даже для хорошо физически подготовленных студентов рекомендуется исключить упражнения, вызывающие повышение внутрибрюшного давления и затрудняющие деятельность органов брюшной полости и малого таза.

К таким упражнениям относятся прыжки в глубину, поднимание больших тяжестей и другие, сопровождающиеся задержкой дыхания.

При выполнении упражнений на силу и быстроту движений следует постепенно увеличивать тренировочную нагрузку, более плавно доводить ее до оптимальных пределов, чем при занятиях мужчин.

Упражнения с отягощениями применяются с небольшими весами, сериями по 8-12 движений с вовлечением в работу различных мышечных групп. В интервалах между сериями выполняются упражнения на расслабление с глубоким дыханием и другие упражнения, обеспечивающие активный отдых.

Функциональные возможности аппарата кровообращения и дыхания у девушек и женщин значительно ниже, чем у юношей и мужчин, поэтому нагрузка на выносливость для девушек и женщин должна быть меньше по объему и повышаться на более продолжительном отрезке времени.

Женщинам при занятиях физическими упражнениями и спортом следует особенно внимательно осуществлять самоконтроль. Необходимо наблюдать за влиянием занятий на течение менструального цикла и характер его изменения. Во всех случаях неблагоприятных отклонений необходимо обращаться к врачу [5].

Женщинам противопоказаны физические нагрузки, спортивная тренировка и участие в спортивных соревнованиях в период беременности.

После родов к занятиям физическими упражнениями и спортом рекомендуется приступать не ранее, чем через 8-10 месяцев.

\section{4. У правление самостоятельными занятиями}


Чтобы управлять процессом самостоятельных занятий, необходимо провести ряд мероприятий: определить цели самостоятельных занятий; определить индивидуальные особенности занимающегося; скорректировать планы занятий (перспективный, годичный, на семестр и микроцикл); определить и изменить содержание, организацию, методику и условия занятий, применяемые средства тренировки. Все это необходимо, чтобы достичь наибольшей эффективности занятий в зависимости от результатов самоконтроля и учета тренировочных занятий. Учет проделанной тренировочной работы позволяет анализировать ход тренировочного процесса, вносить коррективы в планы тренировок. Рекомендуется проводить предварительный, текущий и итоговый учет с записью данных в личный дневник самоконтроля.

Цель предварительного учета - зафиксировать данные исходного уровня подготовленности и тренированности занимающихся.

Текущий учет позволяет анализировать показатели тренировочных занятий. В ходе тренировочных занятий анализируются: количество проведенных тренировок в неделю, месяц, год; выполненный объем и интенсивность тренировочной работы: результаты участия в соревнованиях и выполнения отдельных тестов и норм разрядной классификации. Анализ показателей текущего учета позволяет проверять правильность хода тренировочного процесса и вносить необходимые поправки в планы тренировочных занятий.

Итоговый учет осуществляется в конце периода занятий или конце годичного цикла тренировочных занятий. Он предполагает сопоставить данные состояния здоровья и тренированности, а также данные объема тренировочной работы, выраженной во времени, которое затрачено на выполнение упражнений, и в количестве километров легкоатлетического бега, бега на лыжах и плавания различной интенсивности с результатами, 
показанными на спортивных соревнованиях. На основании этого сопоставления и анализа корректируются планы тренировочных занятий на следующий годичный цикл [27].

Результаты многих видов самоконтроля и учета при проведении самостоятельных тренировочных занятий могут быть представлены в виде количественных показателей: ЧСС, масса тела, тренировочные нагрузки, результаты выполнения тестов, спортивные результаты и др. Информация о количественных показателях позволит занимающемуся в любой отрезок времени ставить определенную количественную задачу, осуществлять ее в процессе тренировки и оценивать точность ее выполнения.

Количественные данные самоконтроля и учета полезно представлять в виде графика, тогда анализ показателей дневника самоконтроля, предварительного, текущего и итогового учета будет более наглядно отображать динамику состояния здоровья, уровня физической и спортивной подготовленности занимающихся, что облегчит повседневное управление процессом самостоятельной тренировки.

К управлению процессом самостоятельных занятий относится дозирование физической нагрузки, ее интенсивности на занятиях физическими упражнениями.

Физические упражнения не принесут желаемого эффекта, если физическая нагрузка недостаточна. Чрезмерная по интенсивности нагрузка может вызвать в организме явления перенапряжения. Возникает необходимость установить оптимальные, индивидуальные дозы физической активности для каждого, кто занимается самостоятельно какой-либо системой физических упражнений или видом спорта. Для этого необходимо определить исходный уровень функционального состояния организма перед началом занятия и затем в процессе занятий контролировать изменение его показателей. 
При дозировании физической нагрузки, регулировании интенсивности ее воздействия на организм необходимо учитывать следующие факторы:

количество повторений упражнения. Чем больше число раз повторяется упражнение, тем больше нагрузка, и наоборот;

$>$ амплитуда движений. С увеличением амплитуды нагрузка на организм возрастает;

исходное положение, из которого выполняется упражнение, существенно влияет на степень физической нагрузки. К ней относятся: изменение формы и величины опорной поверхности при выполнении упражнений (стоя, сидя, лежа); применение исходных положений, изолирующих работу вспомогательных групп мышц ( c помощью гимнастических снарядов и предметов), усиливающих нагрузку на основную мышечную группу и на весь организм; изменение положения центра тяжести тела по отношению к опоре;

$>$ величина и количество участвующих в упражнении мышечных групп.

Чем больше мышц участвует в выполнении упражнения, чем они крупнее по массе, тем значительнее физическая нагрузка;

$>$ темп выполнения упражнений может быть медленным, средним, быстрым.

В циклических упражнениях, например, большую нагрузку дает быстрый темп, в силовых - медленный темп;

$>$ - степень сложности упражнения зависит от количества участвующих в упражнениях мышечных групп и от координации их деятельности.

Сложные упражнения требуют усиленного внимания, что создает значительную эмоциональную нагрузку и приводит к более быстрому утомлению; 
степень и характер мышечного напряжения. При максимальных напряжениях мышцы недостаточно снабжаются кислородом и питательными веществами, быстро нарастает утомление. Трудно долго продолжать работу и при быстром чередовании мышечных сокращений и расслаблений, ибо это приводит к высокой подвижности процессов возбуждения и торможения в коре головного мозга и к быстрому утомлению;

$>$ мощность мышечной работы (количество работы в единицу времени) зависит от времени ее выполнения, развиваемой скорости и силы при движении. Чем больше мощность, тем выше физическая нагрузка;

продолжительность и характер пауз отдыха между упражнениями. Более продолжительный отдых способствует более полному восстановлению организма. По характеру паузы отдыха могут быть пассивными и активными.

При активных паузах, когда выполняются легкие упражнения разгрузочного характера или упражнения в мышечном расслаблении, восстановительный эффект повышается [13].

Учитывая перечисленные факторы, можно уменьшать или увеличивать суммарную физическую нагрузку в одном занятии и в серии занятий в течение продолжительного периода времени.

Тренировочные нагрузки характеризуются рядом физических и физиологических показателей. $\mathrm{K}$ физическим показателям нагрузки относятся количественные признаки выполняемой работы (интенсивность и объем, скорость и темп движений, величина усилия, продолжительность, число повторений). Физиологические параметры характеризуют уровень мобилизации функциональных резервов организма (увеличение ЧСС, ударного объема крови, минутного объема).

Тренировочные нагрузки, выполняемые при ЧСС 131-150 уд/мин. относят к «аэробной» (первой) зоне, когда энергия вырабатывается в 
организме при достаточном притоке кислорода с помощью окислительных реакций.

Вторая - «смешанная», ЧСС 151-180 уд/мин. В этой зоне к аэробным механизмам энергообеспечения подключаются анаэробные, когда энергия образуется при распаде энергетических веществ в условиях недостатка кислорода [12].

Самочувствие довольно точно отражает изменения, происходящие в организме под влиянием занятий физическими упражнениями. Очень важно при самостоятельных занятиях знать признаки чрезмерной нагрузки.

\section{5. Энергозатраты при физической нагрузке разной} интенсивности

Кроме физических и функциональных показателей тренировочной нагрузки при самостоятельных занятиях физическими упражнениями целесообразно ориентироваться на показатели энергетических затрат организма.

В среднем энергозатраты для работников умственного труда, в том числе для студентов, составляют 2700-3000 ккал/сут., из них на мышечную работу затрачивается 1200-2000 ккал.

Таблица 3 - Примерный расход энергии при различных видах физических упражнений (Л.Я.Иващенко, Н.П.Страпко)

\begin{tabular}{|l||l|l||}
\hline Физические упражнения & Скорость, км/ч & $\begin{array}{l}\text { Расход } \\
\text { ккал/ч }\end{array}$ \\
\hline Ходьба & $3,0-4,0$ & $200-240300-350$ \\
\hline \hline Бег & $5,0-6,0$ & $\begin{array}{l}480-500600-650 \\
800-1000\end{array}$ \\
\hline
\end{tabular}




\begin{tabular}{|l|l|l||}
\hline Бег на лыжах & $5,0-6,0$ & $\begin{array}{l}450-500600-700 \\
700-1100\end{array}$ \\
\hline \hline Волейбол & $6,0-6,5$ & $250-300$ \\
\hline \hline Баскетбол & $9,0-10,0$ & 550 - 600 \\
\hline \hline Футбол & $11,0-13,0$ & 450 - 500 \\
\hline \hline Теннис & $7,0-8,0$ & $400-450$ \\
\hline Утренняя гимнастика & $9,0-10,0$ & $40-50$ \\
\hline $\begin{array}{l}\text { Комплексные занятия по физической } \\
\text { культуре 90 мин. }\end{array}$ & $10-15,0$ & $400-500$ \\
\hline
\end{tabular}

Энергетическая стоимость тренировочных нагрузок строго индивидуальна и зависит от пола, возраста и уровня физического состояния.

\section{6. Гигиена самостоятельных занятий}

Гигиена питания, питьевого режима, уход за кожей. Закаливание.

Питание строится с учетом специфики вида физических упражнений и индивидуальных особенностей занимающихся.

Пища должна содержать необходимое количество основных веществ, в сбалансированном виде в соответствии с рекомендуемыми нормами. Рацион должен быть максимально разнообразным и включать наиболее биологически ценные продукты животного и растительного происхождения, отличающиеся разнообразием, хорошей усвояемостью, приятным вкусом, запахом и внешним видом, доброкачественностью и безвредностью [5].

В суточном режиме следует установить и строго придерживаться определенного времени для приема пищи, что способствует ее лучшему перевариванию и усвоению. Принимать пищу следует за 2-2,5 ч. до тренировки и спустя 30-40 мин. после ее окончания. Ужинать нужно не позднее, чем за 2 ч. до сна. Обильный ужин или ужин непосредственно 
перед приводит к снижению усвояемости пищи, влечет за собой плохой сон и понижение умственной или физической работоспособности на следующий день.

Во время спортивных соревнований нельзя резко менять привычный режим питания. Следует с осторожностью применять новые пищевые продукты, так как ко всякой новой пище организм должен приспособиться.

Питьевой режим.

В случаях даже частично обеднения организма водой, могут возникать тяжелые расстройства в его деятельности. Однако избыточно потребление воды также приносит вред организму. Многие потребляют жидкость часто и в большом количестве в силу привычки. Излишнее количество воды, поступающее во внутреннюю среду организма, перегружает сердце и почки, приводит к вымыванию из организма нужных ему веществ, способствует ожирению, усиливает потоотделение и изнуряет организм. Поэтому выполнять рациональный питьевой режим в повседневной жизни и, особенно, при занятиях физическими упражнениями и спортом - важное условие сохранения здоровья, поддерживания на оптимальном уровне умственной и физической работоспособности.

Суточная потребность человека в воде - 2,5 л. у работников физического труда и у спортсменов она увеличивается до 3 л. и более.

В жаркое время года, а также во время и после занятий физическими упражнениями, когда усиливается потоотделение, потребность организма в воде несколько увеличивается, иногда появляется жажда. В этом случае необходимо воспитывать в себе полезную привычку: воздерживаться от частого и обильного питья, тогда ощущение жажды будет появляться реже, однако при этом следует полностью восполнять потерю воды. Надо учитывать, что вода, выпитая сразу, не уменьшает жажду, так как ее всасывание и поступление в кровь и ткани организма происходит в 
течение 10-15 мин. Поэтому, утоляя жажду, рекомендуется, сначала прополоскать ротовую полость и горло, а затем выпивать по несколько глотков воды 15-20 мин.

Лучшим напитком, утоляющим жажду, является чай, особенно зеленый, который можно пить умеренно горячим или в остуженном виде. Хорошо утомляют жажду также хлебный квас, газированная и минеральная вода, томатный сок, настой шиповника, фруктовые и овощные отвары. Высокими жаждоутоляющими свойствами обладают молоко и молочнокислые продукты (кефир, простокваша), они содержат много необходимых человеку минеральных солей и витаминов.

В жаркую погоду полезно употреблять в пищу больше овощей и фруктов, содержащаяся в них вода всасывается медленно, благодаря чему улучшается деятельность потовых желез.

В отдельных случаях, когда высокая температура окружающего воздуха сочетается с большой физической нагрузкой, может возникать ложная жажда, при которой хочется пить, хотя в организме еще не произошла большая потеря воды. Ложная жажда чаще всего сопровождается сухостью во рту. В таких случаях достаточно прополоскать рот и горло прохладной водой [8].

Гигиена тела способствует нормальной жизнедеятельности организма, улучшению обмена веществ, кровообращения, пищеварения, дыхания, развитию физических и умственных способностей человека. От состояния кожного покрова зависит здоровье человека, его работоспособность, сопротивляемость различным заболеваниям.

Кожа представляет сложный и важный орган человеческого тела, выполняющий многие функции: она защищает внутреннюю среду организма, выделяет из организма продукты обмена веществ, осуществляет теплорегуляцию. В коже находится большое количество нервных окончаний, и поэтому она обеспечивает постоянную информацию 
организма о всех действующих на тело раздражителях. Подсчитано, что на $1 \mathrm{~cm}^{2}$ поверхности тела приходится около 100 болевых, 12-15 холодовых, 1-2 тепловых и около 25 точек, воспринимающих атмосферное давление.

Все эти функции выполняются в полном объеме только здоровой и чистой кожей. Загрязненность кожи, кожные заболевания ослабляют ее деятельность, что отрицательно сказывается на состоянии здоровья человека.

Основа ухода за кожей - регулярное мытье тела горячей водой с мылом и мочалкой. При систематических занятиях физическими упражнениями оно должно проводиться не реже одного раза в 4-5 дней, а также после каждой интенсивной физической тренировки, под душем, в ванне или бане. Менять нательное белье после этого обязательно.

О закаливании как о системе мероприятий, направленных на повышение устойчивости организма к различным воздействиям окружающей среды: холода, тепла, солнечной радиации, колебаний величины атмосферного давления и других.

Напоминаем, что основными гигиеническими принципами закаливания являются: систематичность, постепенность, учет индивидуальных особенностей, разнообразие средств, сочетание общих (воздействующих на весь организм) и местных процедур, самоконтроль. Это относится и к закаливанию воздухом, солнцем и водой.

В этом же разделе хотелось бы дополнительно отметить то, что некоторые водные процедуры могут применяться не только как средства закаливания, но и как средства восстановления организма после физического и умственного утомления, стресса, нарушения психического равновесия и т.п. К ним относятся: горячий душ, теплый душ, контрастный душ, теплые ванны, бани. 
Горячий душ $\left(40-41^{\circ} \mathrm{C}\right)$ продолжительностью до 20 мин. понимает возбудимость чувствительных и двигательных нервов, повышает интенсивность процессов обмена веществ.

Теплый душ (36-37 C) в течение 10-15 мин. действует на организм успокаивающее.

Контрастный душ предполагает смену несколько раз через 5-10 с. горячей $\quad\left(38-40^{\circ} \mathrm{C}\right)$ и холодной $\quad\left(12-18^{\circ} \mathrm{C}\right)$ воды при общей продолжительности 5-10 мин.

Теплые ванны $\left(38-39^{\circ} \mathrm{c}\right)$, а также хвойные ванны $\left(35-36^{\circ} \mathrm{C}\right)$ способствуют быстрому восстановлению сил. Продолжительность процедуры 10-15 мин.

Паровая (русская) и суховоздушная (сауна) бани. Правила пользования баней: до входа в парильное отделение принять теплый душ $\left(35-37^{\circ} \mathrm{C}\right)$, не замочив головы. Затем вытереться досуха; войти в парилку, где 4-6 мин. находиться внизу, прогревшись, подняться на верхний полок и находиться там, в зависимости от самочувствия, 5-7 мин. при этом можно пользоваться березовым или дубовым веником, предварительно распарив его в горячей воде. Количество заходов в парильню за одно посещение бани не более 2-3 раз.

Не рекомендуется посещать баню в болезненном состоянии, натощак и сразу после приема пищи, незадолго до сна, в состоянии сильного утомления.

Категорически запрещается до и после бани употреблять алкогольные напитки [9].

Гигиена мест занятий. При занятиях в помещении не допускается наличие в воздухе даже незначительного количества вредных веществ, пыли, увеличенного процентного содержания углекислого газа. Запрещается курение. Пол должен быть ровным, нескользким без выбоин и выступов. 
Используя тренажеры и другие технические средства, следует проверять их соответствие гигиеническим нормам.

Наибольший оздоровительный эффект дают занятия на открытом воздухе в любое время года. Во избежание загазованности воздуха места занятий в лесу, лесопарке, на скверах выбираются на удалении 300-500 м. от автомобильных дорог и магистралей, от производственных зданий, учитывая направление и скорость движения воздуха.

При занятиях на спортивных сооружениях гигиенические условия обеспечиваются их администрацией.

Одежда должна отвечать требованиям, предъявляемым спецификой занятий той или иной системой физических упражнений или видом спорта.

При занятиях в летнее время одежда состоит из майки и трусов, в прохладную погоду используется хлопчатобумажный или шерстяной трикотажный, спортивный костюм. Во время занятий зимними видами спорта используется спортивная одежда с высокими теплозащитными и ветрозащитными свойствами. Обычно это хлопчатобумажное белье, шерстяной костюм или свитер с брюками, шапочка. При сильном ветре сверху надевается ветрозащитная куртка.

Обувь должна быть легкой, эластичной и хорошо вентилируемой. Она должна быть удобной, прочной, хорошо защищать стопу от повреждений и иметь специальные приспособления для занятий тем или иным видом физических упражнений. Важно, чтобы спортивная обувь и носки были чистыми и сухими во избежание потертостей, а при низкой температуре воздуха - обморожения.

Для занятий зимними видами физических упражнений рекомендуется непромокаемая обувь, обладающая высокими теплозащитными свойствами. Ее размер должен быть чуть больше обычного, что даст возможность использовать теплую стельку, а при необходимости две пары носков [24]. 
На соревнованиях и во время туристических походов следует пользоваться только хорошо разношенной обувью.

\section{7. Профилактика травматизма}

Причинами травматизма могут быть: нарушения в методике занятий; невыполнение методических принципов доступности, постепенности и учета индивидуальных особенностей, неудовлетворительное состояние инвентаря и оборудования, плохая подготовка мест занятий; незнание и несоблюдение мероприятий по самостраховке; перегрузка занимающимися площадок и залов по сравнению с нормами площади на одного занимающегося; плохое санитарно-техническое состояние мест занятий, недостаток освещения, скользкие полы, отсутствие вентиляции; недисциплинированность занимающихся и др.

Необходимо учитывать внутренние факторы, вызывающие спортивные травмы. К ним относятся занятия в состоянии утомления и переутомления, а также при наличии в организме хронических очагов инфекции, при склонности к спазмам кровеносных сосудов и мышц и в других болезненных состояний.

Для профилактики переохлаждений и перегреваний важно учитывать погодные факторы (температура, влажность, ветер), степень закаленности занимающихся и соответствие этим факторам одежды и обуви.

Возможные телесные повреждения при занятиях различными видами физических упражнений должны тщательно изучаться и анализироваться, чтобы вырабатывать конкретные меры предупреждения и ликвидации условий их возникновения.

\section{8. Самоконтроль при занятиях физической культурой и} спортом 
Самоконтроль спортсмена - это регулярное использование им ряда простых приемов для самостоятельного наблюдения за изменением состояния своего здоровья и физического развития под влиянием занятий физическими упражнениями.

Благодаря самонаблюдению спортсмен имеет возможность самостоятельно контролировать тренировочный процесс. Кроме того, самоконтроль имеет большое воспитательное и педагогическое значение, приучая спортсмена к активному наблюдению и оценке своего состояния, к анализу используемой методики тренировки.

Самоконтроль служит важным дополнением к врачебному контролю, но, ни в коем случае не может его заменить. Данные самоконтроля могут оказать

Большую помощь преподавателю и тренеру в регулировании тренировочной нагрузки, а врачу - правильной оценке выявленной изменении, в состоянии здоровья спортсмена и его физическом развитии.

Преподаватель, тренер и врач должны разъяснять спортсменам значение регулярного самоконтроля для укрепления здоровья, правильного построения учебно-тренировочного процесса и повышение спортивного повышения, рекомендовать пользоваться определенными методами наблюдений, объясняя, как должны изменяться те или иные показатели самонаблюдений (например, сон, пульс, вес) при правильном построении тренировок и случаях нарушений режима.

Преподаватель и тренер совместно с врачом должны добиваться, чтобы спортсмены правильно понимали изменения различных функций организма под влиянием физических нагрузок. Необходимо предостеречь спортсменов от поспешных выводов при появлении отклонений в показателях самонаблюдений, так как за неправильными выводами может последовать неправильное построение тренировок, а также возможное 
самовнушение какого-либо заболевания, которого у спортсменов фактически нет. Важно разъяснить спортсменам, что при отклонениях показателей, выявлененных при самоконтроле, необходимо посоветоваться с врачом и преподавателем или тренером, прежде чем принимать какие-либо меры [25].

Существенным, является ведение дневника самоконтроля, представляющего собой часть дневника тренировок, который обязан вести каждый спортсмен. Врач и преподаватель, тренер, просматривая этот дневник, смогут увидеть зависимость изменений в состоянии здоровья спортсмена от содержания и характера тренировки.

Показатели самоконтроля принято делить на субъективные и объективные.

В группу субъективных показателей входят самочувствие, оценка работоспособности, отношение к тренировкам, сон, аппетит и т.п. Значение каждого из этих признаков в самоконтроле следующее.

Самочувствие складывается из суммы признаков: наличия (или отсутствия) каких-либо необычных ощущений, болей с той или иной локализацией, ощущения бодрости или, наоборот, усталости, вялости, и Т.П.

Самочувствие может быть: хорошее, удовлетворительное или плохое. При появлении каких-либо необычных ощущений отмечают их характер, указывают, после чего они возникли (например, появление мышечных болей после занятий). Боли в мышцах обычно возникают при тренировке после перерыва или при очень быстром увеличении нагрузок -перегрузки. При беге у спортсменов могут появляться боли в правом (в области печени) и левом (в области селезёнки) подреберье.

Боли в правом подреберье могут возникать при заболеваниях печени и желчного пузыря, нарушениях деятельности сердца. Иногда спортсмены жалуются на боли в области сердца. В случае появления болей сердце во 
время работы спортсмен должен немедленно обратиться к врачу. При утомлении и переутомлении могут также возникать головные боли, головокружение, появление которых спортсмен должен обязательно отмечать в дневнике самоконтроля.

Усталость - это субъективное ощущение утомления, которое выявляется в нежелании или невозможности выполнить обычную трудовую нагрузку, а также физические упражнения, намеченные по плану. При самоконтроле отмечается, зависит ли усталость от проводимых занятий или от чего-то другого, как скоро она появляется, ее продолжительность.

Спортсмен должен отмечать, степень усталости после занятий ( «не устал», «немного устал», «переутомился»), а на следующий день после тренировки - «усталости нет», «чувствую себя хорошо», «осталось чувство усталости», «полностью не отдохнул», «чувствую себя утомленным».

Важно также отмечать настроение: нормальное, устойчивое, подавленное, угнетённое; желание быть в одиночестве, чрезмерное возбуждение.

Работоспособность зависит от общего состояния организма, настроения, утомления, от предшествующей работы (профессиональной и спортивной). Работоспособность оценивается как повышенная, обычная и пониженная.

Отсутствие желания тренироваться и соревноваться может быть признаком перетренированности.

Нормальный сон, восстанавливая работоспособность центральной нервной системы, обеспечивает бодрость, свежесть. В случае переутомления нередко появляется бессонница или повышенная сонливость, неспокойный сон (часто прерывается, сопровождается тяжелыми сновидениями). После сна возникает чувство разбитости. Спортсмен должен регистрировать количество часов сна (помня, что сон 
должен быть не менее 7-8 часов, при больших физических нагрузках - 9-10 часов) и его качество, а при нарушениях сна - их проявления плохое засыпание, частое или раннее пробуждение, сновидения, бессонница и т.п.

Аппетит отмечается как нормальный, сниженный или повышенный. Его ухудшение или отсутствие часто указывают на утомление или болезненное состояние.

Из объективных признаков при самоконтроле регистрируются частота пульса, вес, потоотделение, данные спирометрии, динамометрии, реже определяется частота дыхания (так как трудно подсчитывать число дыханий у самого себя) или проводятся какие-либо другие функциональные пробы.

Необходимо также, чтобы спортсмен периодически подсчитывал пульс после определённых спортивных нагрузок. У хорошо тренированных спортсменов даже после очень больших нагрузок частота пульса не превышает обычно 180-200 ударов в минуту. Длительность восстановления частоты пульса после определенных спортивных нагрузок служит важным показателем функционального состояния спортсмена.

Определение веса (путем взвешивания) достаточно проводить 1-2 раза в неделю. Исключение составляют те случаи, когда необходимо строго регулировать вес в соответствии с весовой категорией период соревнований (у боксеров, борцов, штангистов). Проверку веса лучше всего проводить утром, натощак (после опорожнения мочевого пузыря и кишечника). Если практически это не всегда возможно, то следует взвешиваться всегда в одно то же время дня на одних и тех же весах, без одежды.

Огромное значение имеет питание. Обильное питание в период достигнутой спортивной формы может вызвать необычное для данного состояния увеличение веса тела. Чрезмерное падение веса, которое непосредственно не связано с ошибками в методике и нагрузке занятий, 
может быть обусловлено неправильным общим режимом и недостаточным питанием [13].

Преподаватель и тренер должны не реже одного раза в 1-2 недели проверять дневник самоконтроля спортсмена. Врач обязательно знакомится с ним при повторных обследованиях спортсмена.

Для оценки функционального состояния можно использовать следующие доступные функциональные пробы:

1. Степ-тест Кэрша, рекомендуемый для здоровых женщин. Здесь потребуется скамейка или прочный стульчик высотой 30 см.

Необходимо встать на скамейку и сходить с неё на 4 счета: на счет «раз» поставить одну ногу на скамью, на «два» - другую, на «три» опустить одну ногу на пол, на «четыре» - другую. Темп должен быть следующим: два полных шага вверх и вниз за 5 сек., 24 - за 1 мин. Продолжать выполнение теста течения 3 мин. Проведя тест, сразу сесть на скамейку и подсчитать пульс в течение 1 мин. Затем сравнить полученный результат (пульс в течение 1 мин.) с данными таблицы, чтобы узнать насколько вы хорошо подготовлены.

Таблица 4 - Результаты Степ-теста по Кэршу

\begin{tabular}{|l|l|l||}
\hline \hline ОЦЕНКА & \multicolumn{2}{|l|}{$\begin{array}{l}\text { Частота сердечных сокращений (уд.мин.) в зависимости } \\
\text { от возраста }\end{array}$} \\
\hline \hline & $18-26$ лет & $27-60$ лет \\
\hline \hline Превосходно & & \\
\hline Отлично & $74-82$ & $75-83$ \\
\hline \hline Хорошо & $83-90$ & $84-92$ \\
\hline Удовлетворительно & $91-100$ & $93-103$ \\
\hline \hline Посредственно & $101-107$ & $104-112$ \\
\hline \hline Плохо & $108-114$ & $113-121$ \\
\hline Очень плохо & \\
\hline
\end{tabular}


Если этот тест окажется для вас слишком легким, если вы высокого роста, и полученные данные не будут отражать истинное положение дел, предлагается всем, кто выше 152 см., увеличивать высоту скамейки на 5 см. на каждые 7,5 см. роста.

2. Для оценки состояния дыхательной, сердечно-сосудистой и регуляторной систем в ответ на изменение внутренней среды организма (снижение содержания кислорода и увеличение концентрации $\mathrm{CO}_{2}$ в крови) применяют в целях самоконтроля функциональной пробы с задержкой дыхания.

Проба Штанге - задержка дыхания на вдохе.

После 5 мин. отдыха сидя сделать 2-3 глубоких вдоха и выдоха, а затем, сделав полный вдох, задержать дыхание и одновременно включить секундомер. При возобновлении дыхания секундомер останавливают.

Средним показателем способности задерживать дыхание на вдохе следует считать время равное 60-65 сек. При заболевании или переутомлении это время уменьшается значительно (до 30-35 сек.)

Проба Генчи - задержка дыхания на выдохе. Задержка дыхания производится после полного выдоха. Средним показателем здесь является способность задерживать дыхания на выдохе в течение 30 сек.

3. О реакции сердечно-сосудистой системы на физическую нагрузку достаточно объективно можно судить по результатам так называемой ортостатической пробы. Их несколько. Наиболее часто в практике с используется такая: отдых лежа 5 мин., подсчет пульса - 1 мин., отдых стоя - 1 мин., подсчет пульса - 1 мин.. После этого вычисляется разность пульса в положениях лежа и стоя. Критерии оценок: менее 12 сокращений -хорошая, 12-18 - удовлетворительная, 19-25 - плохая, более 25 - очень плохая.

4. Дыхание. Большой информативностью о потенциальных возможностях аппарата обладает показатель ЖЕЛ (жизненная емкость 
легких) - максимальный объем воздуха, который человек может выдохнуть после глубокого вдоха.

Средними показателями для юношей в возрасте 16-18 лет являются величины в пределах 4000-4500 $\mathrm{cm}^{3}$, а для девушек этого же возраста 3000-3500 $\mathrm{cm}^{3}$. У физкультурников и спортсменов эти показатели достигают 6000 и даже $7000 \mathrm{~cm}^{3}$ (гребцы, пловцы, лыжники).

5. Масса тела, показатели силы мышц. Динамика спортивных результатов - яркие и объективные признаки правильного построения тренировочного процесса.

Измерить массу тела (вес) следует еженедельно, в одно и то же время, на одних и тех же весах, предварительно проверив их исправность.

В зависимости об состояния здоровья, водного и пищевого режима, учебной или тренировочной нагрузки и других влияний масса тела может меняться. Прогрессирующая потеря аппетита и снижение массы тела сигнализируют о неблагополучии в организме спортсмена. Об этом следует поставить в известность тренера и врача. У систематически тренирующихся спортсменов колебания массы постоянны: после напряженной тренировки потеря массы тела составляет 1-2 кг. В период отдыха масса полностью восстанавливается [27].

Снижение показателей силы отдельных групп мышц, прекращение роста спортивных достижений обычно связаны с нарушением общего или тренировочного режима.

Для самоконтроля каждому спортсмену желательно использовать одно или несколько контрольных тестов, например: подтягивание на перекладине, поднимание ног из виса на гимнастическом стенке, лазание по канату на время и т.д.

На спортивные результаты отрицательно влияют недосыпание, беспорядочное питание, частые внеплановые физические нагрузки, 
выступления на соревнованиях без достаточной подготовки, тренировки в болезненном состоянии, курение, употребление алкоголя.

\section{Контрольные вопросы}

1. Что является целью диагностики?

2. Назовите основные виды диагностики.

3. Какова периодичность врачебного контроля для студентов?

4. Какова периодичность врачебного контроля для спортсменов?

5. Укажите основное предназначение врачебного обследования.

6. На что направлены мероприятия врачебного контроля?

7. Что понимается под физическим развитием человека?

8. Какой тип осанки считается нормальным?

9. Как называются боковые искривления позвоночника?

10. До какого возраста можно ожидать увеличение роста у юношей?

11. До какого возраста можно ожидать увеличение роста у девушек?

12. С помощью какого прибора определяется жизненная емкость лёгких?

13. Какие характеристики лежат в основе антропометрических стандартов?

14. На чём основан метод корреляции?

15. Как вычисляется весо-ростовой показатель?

16. Как вычисляется росто-весовой показатель?

17. Какая должна быть масса тела у человека, если его рост равен 171 см?

18. Определите оптимальную величину пульса при продолжительных физических упражнениях для начинающих в возрасте 20 лет.

19. Каковы параметры физической нагрузки одномоментной функциональной пробы с приседанием? 
20. На чем основан метод определения физической работоспособности PWC170?

21. Напишите формулу для вычисления PWC170.

22. Что оценивается с помощью Гарвардского степ-теста?

23. Напишите формулу для вычисления Гарвардского степ-теста.

24. Что является оценкой теста Купера?

25. С какой целью проводится педагогический контроль?

26. Назовите виды педагогического контроля.

27. Назовите типы психофизического состояния занимающихся физической культурой.

28. Что является целью самоконтроля?

29. К каким данным самоконтроля (объективным или субъективным) относится самочувствие?

30. К каким данным самоконтроля (объективным или субъективным) относится масса тела?

31. Разница в пульсе при ортостатической пробе составила 10 уд/мин. О чем это свидетельствует?

32. После подъема на 4-й этаж ваш пульс составил 105 уд/мин. Оцените состояние сердечно-сосудистой системы.

33. Какова задержка дыхания на вдохе (проба Штанге) у здоровых взрослых людей?

34. Какова задержка дыхания на выдохе (проба Генчи) тренированных людей?

35. Какую величину пульса не следует превышать при занятиях физическими упражнениями в возрасте 18 лет?

Тема 4. Социально-биологические основы

Физической культуры 


\section{План :}

4.1. Основные понятия.

4.2. Организм человека как биосистема

4.3. Кровеносная система.

4.5. Нервная система.

4.6. Эндокринная система.

4.7. Функции дыхания.

\section{1 Основные понятия}

Организм человека - целостная система, в которой все органы тесно связаны между собой и находятся в сложном взаимодействии; эта система способна к саморегуляции, поддержанию гомеостаза, корригированию и самосовершенствованию (И.П.Павлов).

Гомеостаз (греч. - стояние) - поддержание динамического постоянства внутренней среды организма за счет приспособительных реакций, направленных на устранение внешних или внутренних факторов, нарушающих это постоянство.

Рефлекс (лат. - отражение) - ответная реакция организма на воздействия, осуществляющиеся через центральную нервную систему.

Адаптация (лат. - приспособлять) - совокупность реакций организма или органа к изменению окружающей среды.

Гиподинамия (греч. - понижение + относящийся к силе) пониженная подвижность вследствие уменьшения силы движения.

Гипокинезия (греч. - понижение + движение) - вынужденное уменьшение объема движений вследствие малой подвижности. Вызывает ряд болезненных явлений. 
Гипоксия (греч. - понижение + лат. - кислород) - кислородное голодание - пониженное содержание кислорода в тканях.

Максимальное потребление кислорода (МПК) - критерий функционального состояния дыхательной и кровеносной систем.

Двигательные умения, навыки - форма двигательных стереотипов, выработанных по механизму условного рефлекса соответствующими упражнениями.

Онтогенез (греч. - сущее + происхождение) - индивидуальное развитие организма, охватывающее все изменения от рождения до окончания жизни. Рассматривается в единстве с филогенезом.

Филогенез, филогения (греч. - племя, род, вид + происхождение) историческое развитие организмов или эволюция органического мира, различных типов, классов, отрядов, семейств, родов и видов. Можно говорить о филогенезе тех или иных органов. Рассматривается во взаимообусловленности и единстве с онтогенезом [10].

Наблюдайте за вашим телом, если хотите, чтобы ваш ум работал правильно.Р. Декарт

\section{2. Организм человека как биосистема}

Человеческий организм - сложная биологическая система. Все органы человеческого тела взаимосвязаны, находятся в постоянном взаимодействии и в совокупности, являются единой саморегулируемой и саморазвивающейся системой. Деятельность организма как единого целого включает взаимодействие психики человека, его двигательных и вегетативных функций с различными условиями окружающей среды.

Физические упражнения оказывают существенное влияние на формирование скелета (исправляются искривления позвоночника, улучшается осанка). Повышаются обменные процессы, в частности, обмен 
кальция, содержание которого определяет прочность костей. Скелет, выполняя опорную и защитную (череп, грудная клетка, кости таза и др.) функции, чрезвычайно прочен. Отдельные кости выдерживают нагрузку до 2 тонн. Непрерывное (кости черепа и др.) и суставное соединения костей дают возможность составлять отдельные блоки, кинематические системы с большой степенью свободы, дающие возможность звеньям таких систем перемещаться по сложным траекториям.

Сложный комплекс связанных друг с другом реакций расщепления (диссимиляции) и синтеза (ассимиляции) органических веществ - основа развития организма человека.

Организм человека развивается под влиянием генотипа (наследственности), а также факторов постоянно изменяющейся внешней природной и социальной среды [3].

Не зная строения организма человека, особенности процессов жизнедеятельности в отдельных его органах, системах органов и в целостном организме, нельзя обучать, воспитывать и лечить человека, а также обеспечить его физическое совершенствование.

Познание самого себя является важным шагом в решении проблемы формирования физической культуры личности будущего специалиста, который при изучении данной темы должен:

$>$ исследовать особенности функционирования человеческого организма и отдельных его систем под влиянием занятий физическими упражнениями и спортом в различных условиях внешней среды;

$>\quad$ уметь диагностировать состояние своего организма и отдельных его систем, вносить необходимую коррекцию в их развитие средствами физической культуры и спорта;

$>$ уметь рационально адаптировать физкультурно-спортивную деятельность к индивидуальным особенностям организма, условиям труда, 
быта, отдыха и дифференцировать использование средств физической культуры и спорта с учетом отмеченных особенностей.

В организме человека насчитывается более 100 трлн. $\left(1 \times 10^{14}\right)$ клеток. Каждая клетка представляет собой одновременно фабрику по переработке веществ, поступающих в организм; электростанцию, вырабатывающую биоэлектрическую энергию; компьютер с большим объёмом хранения и выдачи информации. Кроме этого определенные группы клеток выполняют специфические, присущие только им функции (мышцы, кровь, нервная система и др.).

Наиболее сложное строение имеют клетки центральной нервной системы (ЦНС) 一нейроны. Их насчитывается в организме более 20 млрд. Каждый нейрон содержит около тысячи ферментов. Все нейроны головного мозга могут накапливать свыше 10 млрд. единиц информации в 1 секунду, т.е. в несколько раз больше, чем самая совершенная компьютерная система.

Внешняя деятельность человека и внутренние процессы, протекающие в организме, осуществляются по механизму рефлекса, управляемого из ЦНС.

Каждая клетка, группа клеток, орган работают в двух режимах: возбуждения (деятельное состояние) и торможения (прекращение деятельного состояния и восстановление). Возбуждение и торможение это два противоположных процесса, взаимодействие которых обеспечивает слаженную деятельность нервной системы, согласованную работу органов тела, регуляцию и совершенствование функций всего организма.

Движение - важнейшее свойство организма человека. Благодаря наличию скелетных мышц человек может передвигаться, выполнять движения отдельными частями тела. Постоянные движения происходят и во внутренних органах, также имеющих мышечную ткань в виде особых 
«гладких» мышц (перистальтика кишечника, поддержание тонуса артериальных кровеносных сосудов и т.д.). Сложное строение имеет сердечная мышца, которая непрерывно, на протяжении всей жизни человека, работает в качестве насоса, обеспечивая передвижение крови по кровеносным сосудам.

При эволюционном развитии человека в онто- и филогенезе двигательная активность оказала существенное влияние на морфологенез отдельных органов и систем организма.

Организм человека состоит из отдельных органов, выполняющих свойственные им функции. Различают группы органов, выполняющие совместно общие функции - системы органов. В своей функциональной деятельности системы органов связаны между собой.

Многие функциональные системы в значительной степени обеспечивают двигательную деятельность человека. К ним относятся кровеносная система, система органов дыхания, опорно-двигательная и пищеварительная системы, а также органы выделения, железы внутренней секреции, сенсорные системы, нервная система и др [18].

Медицинская наука рассматривает человеческий организм в единстве с внешней природой и социальной средой.

Внешняя среда в общем виде может быть представлена моделью, состоящей из трех взаимодействующих элементов: физическая окружающая среда (атмосфера, вода, почва, солнечная энергия); биологическая окружающая среда (животный и растительный мир); социальная среда (человек и человеческое общество).

Влияние внешней среды на организм человека весьма многогранно. Внешняя природная среда и социальная среда могут оказывать на организм как полезные, так и вредные воздействия. Из внешней среды организм получает все необходимые для жизнедеятельности и развития вещества, вместе с тем он получает многочисленный поток раздражений 
(температура, влажность, солнечная радиация, производственные, профессионально вредные воздействия и др.), который стремится нарушить постоянство внутренней среды организма.

Нормальное существование человека в этих условиях возможно только в том случае, если организм своевременно реагирует на воздействия внешней среды соответствующими приспособительными реакциями и сохраняет постоянство своей внутренней среды.

Экологические проблемы оказывают прямое или косвенное влияние на физическое и нравственное состояние человека.

В современном мире проблемы экологии - взаимодействия организма с окружающей средой — серьезно обострились [19].

По данным Всемирной организации здравоохранения, 80\% болезней человека возникают по причинам, связанным с ухудшением экологической ситуации.

Отличительной особенностью человека является то, что он может сознательно и активно изменять как внешние, так и социально-бытовые условия для укрепления здоровья, повышения трудоспособности и продления жизни. Несомненно, что взаимоотношения общества с окружающей средой необходимо поставить под более строгий контроль.

Соответствующим изменением внешних условий человек может воздействовать и на собственное состояние здоровья, физическое развитие, физическую подготовленность, на умственную и физическую работоспособность.

Физическая тренировка оказывает разностороннее влияние на психические функции, обеспечивая их активность и устойчивость.

Имеются результаты многочисленных исследований по изучению у тренированных и нетренированных лиц устойчивости внимания, восприятия, памяти, способности к устному счету различной сложности, других сторон мышления. Устойчивость изучаемых параметров 
оценивалась по уровню их сохранения под влиянием различной степени утомления, а также по способности сохранять работоспособность в точное время. Установлено, что устойчивость параметров умственной деятельности находилась в прямой зависимости от уровня разносторонней физической подготовленности.

Умственная работоспособность в меньшей степени ухудшается под воздействием неблагоприятных факторов, если в этих условиях соответствующим образом применять физические упражнения. Оптимальная физическая тренированность обеспечивает сохранение ряда показателей высшей нервной деятельности, в частности, устойчивости функций второй сигнальной системы.

Утомление — это состояние, которое возникает вследствие работы при недостаточности восстановительных процессов и проявляется в снижении работоспособности, нарушении координации регуляторных механизмов и в ощущении усталости. Утомление играет важную биологическую роль, служит предупредительным сигналом возможного перенапряжения рабочего органа или организма в целом.

Различают две фазы развития утомления: компенсированную и некомпенсированную. В компенсированной фазе не происходит видимого снижения работоспособности. Работа осуществляется за счет подключения к напряженной деятельности других систем организма, которые до наступления утомления не принимали активного участия в данной работе.

Невозможность поддержания нужной интенсивности работы даже при подключении резервных систем организма означает начало некомпенсированной фазы утомления.

При работе значительной интенсивности, не соответствующей уровню непосредственной готовности организма к выполнению данной нагрузки, возникает острое утомление. 
Суммирование сдвигов в нервно-мышечной и ЦНС, возникающих при многократной утомительной работе, вызывает хроническое утомление.

Систематическое продолжение работы в состоянии утомления, неправильная организация труда, физической тренировки, длительное выполнение работы, связанной с чрезмерным нервно-психическим или физическим напряжением, - все это может привести к переутомлению [12].

Острое и хроническое утомление, а также переутомление могут привести к заболеванию нервной системы, обострению сердечнососудистых заболеваний, гипертонической и язвенной болезням, снижению сил организма. Например, под влиянием длительного (хронического) экзаменационного эмоционального стресса у большинства обследованных студентов наблюдались значительные изменения интенсивности кровенаполнения сосудов и реактивности биопотенциалов головного мозга, электрокардиографических и биохимических показателей, не приходящих в норму в течение 2-3 суток после экзаменов.

Таким образом, студенты вузов 2 раза в год переживают длительный эмоциональный стресс, что является фактором риска.

Умственное переутомление граничит с заболеванием и имеет более длительный период восстановления. Оно является следствием того, что мозг человека, обладая большими компенсаторными возможностями, способен длительное время работать с перегрузкой, не давая знать о своем утомлении, которое мы ощущаем только тогда, когда наступила фаза переутомления.

Средствами восстановления организма после утомления и переутомления являются: оптимальная, физическая активность, переключение на другие виды работы и сочетание работы с активным отдыхом, рациональное питание, установление строгого гигиенического образа жизни. Ускоряют процесс восстановления достаточный по времени 
и полноценный сон, водные процедуры, парная баня, массаж и самомассаж, фармакологические средства и физиотерапевтические процедуры, психорегулирующая тренировка.

Ритмичное протекание физиологических процессов - это важное свойство живого организма. Все в организме - каждый орган, клетка, состав крови, гормоны, температура тела, частота сердечных сокращений (ЧСС), кровяное давление, дыхание и другие системы, и показатели их функций - имеет свои собственные ритмы, измеряемые в секундах, часах, месяцах и даже годах.

Биоритмы отдельных органов и систем взаимодействуют друг с другом и образуют упорядоченную систему ритмических процессов организацию деятельности организма во времени. Например, различают суточный биоритм, при котором высокий уровень работоспособности у человека, наблюдается примерно с 8.00 до 12.00 и с 17.00 до 19 часов. В эти часы активизируются почти все функции организма. Значительно снижаются психофизические функции в периоды от 2 до 3 часов ночи и от 13.00 до 15.00 часов дня.

При проявлении работоспособности наиболее результативными являются вторник, четверг и пятница, а нерезультативными понедельник и суббота.

Правильно составленный распорядок дня, распределение работы таким образом, чтобы наибольшая нагрузка соответствовала наибольшим возможностям организма, - одна из важнейших задач сохранения здоровья и трудоспособности.

Нарушение биоритмов, режима рабочего дня, труда, учебных занятий, питания, отдыха, сна, двигательной активности может привести не только к снижению работоспособности, но и к развитию болезни.

Недостаточная двигательная активность создает особые неестественные условия для жизнедеятельности человека, отрицательно 
воздействует на структуру и функции всех тканей организма человека. В этих условиях задерживается развитие молодого поколения и ускоряется старение пожилых людей.

При отсутствии достаточной дозы ежедневных мышечных движений происходят нежелательные и существенные изменения функционального состояния мозга и сенсорных систем. Вследствие этого наблюдается снижение общих защитных сил организма, увеличение риска возникновения различных заболеваний.

Для данного состояния характерны повышенная крайняя неустойчивость настроения, ослабление самообладания, нетерпеливость, нарушение сна, утрата способности к длительному труду или физическому напряжению. Все эти симптомы могут проявляться в различной степени.

Наиболее действенной альтернативой гипокинезии и гиподинамии в современных условиях могут выступать физические упражнения [20].

Прогресс науки и техники вызвал необходимость получения человеком значительного объема профессиональных знаний и большого количества разнообразной информации. Неизмеримо возрос темп жизни. Все это обусловило предъявление к современному человеку высоких требований к его физическому состоянию и значительно увеличило нагрузку на психическую, умственную и эмоциональную сферы.

В связи с активизацией учебного труда при возрастающих нагрузках требуется оздоровление условий и режима учебы, быта и отдыха студентов с использованием средств физической культуры. Средствами физической культуры являются физические упражнения, оздоровительные силы природы (солнце, воздух и вода) и гигиенические факторы (санитарно-гигиеническая обстановка, режим отдыха, сна, питания).

Использование оздоровительных сил природы (закаливание) укрепляет и активизирует защитные силы организма, стимулирует обмен 
веществ, деятельность сердца и кровеносных сосудов, благотворно влияет на состояние нервной системы.

Систематическая физическая тренировка, занятия физическими упражнениями в условиях напряженной учебной деятельности студентов имеют важное значение как способ разрядки нервного напряжения и сохранения психического здоровья. Разрядка повышенной нервной активности через движение является наиболее эффективной.

Роль физических упражнений не ограничивается только благоприятным воздействием на здоровье. Наблюдение за людьми, которые регулярно занимаются физическими упражнениями, показало, что систематическая мышечная деятельность повышает психическую, умственную и эмоциональную устойчивость организма при длительной напряженной умственной или физической работе.

Человек, ведущий подвижный образ жизни и систематически занимающийся физическими упражнениями, может выполнять значительно большую работу, чем человек, ведущий малоподвижный образ жизни. Это связано с резервными возможностями организма [15].

Активизацию физиологических функций организма при мышечной деятельности следует рассматривать как мобилизацию резервов. При этом тренированный организм имеет большие по объему резервы и может более полно их использовать, чем нетренированный.

Каждый орган, система органов и организм в целом под влиянием направленной физической тренировки заметно повышают показатели работоспособности, физического резерва.

Обмен веществ и энергии в организме человека характеризуется сложными биохимическими реакциями. Питательные вещества (белки, жиры и углеводы), поступающие во внутреннюю среду организма с пищей, расщепляются в пищеварительном тракте. Продукты расщепления переносятся кровью к клеткам и усваиваются ими. Кислород, 
проникающий из воздуха через легкие в кровь, принимает участие в процессе окисления, происходящем в клетках.

Вещества, образующиеся в результате биохимических реакций обмена веществ (двуокись углерода, вода, мочевина и др.), выводятся из организма через легкие, почки, кожу.

Обмен веществ является источником энергии для всех жизненных процессов и функций организма. При расщеплении сложных органических веществ содержащаяся в них потенциальная химическая энергия превращается в другие виды энергии (биоэлектрическую, механическую, тепловую и др.).

Интенсивность протекания процесса обмена веществ в организме человека очень велика. Каждую секунду разрушается огромное количество молекул различных веществ, и одновременно образуются новые вещества, необходимые организму. За 3 месяца половина всех тканей тела человека обновляется.

Рост волос, ногтей, шелушение кожи — все это результат процесса обмена веществ. За 5 лет учебы у студента роговица глаза сменяется 250 раз, а ткань желудка обновляется 500 раз.

Для сохранения энергетического баланса, поддержания нормальной массы тела, обеспечения высокой умственной и физической работоспособности и профилактики заболеваний необходимо при достаточном и полноценном питании увеличивать расход энергии за счет повышения двигательной активности, например, с помощью регулярных занятий физическими упражнениями [23].

Мышечная деятельность. Занятия физическими упражнениями или спортом повышают активность обменных процессов, тренируют и поддерживают на высоком уровне механизмы, осуществляющие в организме обмен веществ и энергии. 


\section{3.Кровеносная система}

Кровь в организме человека выполняет следующие основные функции:

1. транспортную - в процессе обмена веществ переносит к тканям тела питательные вещества и кислород, а из тканей к органам выделения транспортирует продукты распада, образующиеся в результате жизнедеятельности клеток тканей;

2. регуляторную - осуществляет гуморальную (гумор - жидкость) регуляцию функций организма с помощью гормонов и других химических веществ и рефлекторную —вследствие гидростатического давления на нервные окончания (барорецепторы), расположенные в стенках кровеносных сосудов;

3. защитную - защищает организм от вредных веществ и инородных тел, кроме этого, при повреждении тканей тела останавливает кровотечение;

4. теплообмена - участвует в поддержании постоянной температуры тела.

Кровь состоит из жидкой части (плазмы) (55\%) и взвешенных в ней форменных элементов (эритроцитов, лейкоцитов и др.) (45\%). Кровь имеет слабую щелочную реакцию.

Эритроциты - красные кровяные тельца, носители дыхательного пигмента -гемоглобина. Их 4-6 млн. в 1 мм³ крови. Эритроциты переносят кислород из легких к тканям и частично углекислый газ из тканей к легким.

Лейкоциты - белые кровяные клетки, их имеется несколько видов. В 1 куб. мм крови содержится 6-8 тыс. лейкоцитов. Они способны проникать через стенки кровеносных сосудов в ткани тела и уничтожать 
болезнетворные микробы и инородные тела, попавшие в организм. Это явление называется «фагоцитозом».

Тромбоциты - кровяные пластинки. Их содержится в крови 100-300 тыс. в 1 мм³ $^{3}$ Они защищают организм от потери крови. При повреждении тела и кровеносных сосудов тромбоциты способствуют свертыванию крови, образованию сгустка (тромба), который закупоривает сосуд и прекращает потерю крови.

При регулярных занятиях физическими упражнениями или спортом: $>$ увеличивается количество эритроцитов и количество гемоглобина в них, в результате чего повышается кислородная емкость крови;

повышается сопротивляемость организма к простудным и инфекционным заболеваниям, благодаря повышению активности лейкоцитов;

$>$ ускоряются процессы восстановления после значительной потери крови.

Кровь в организме находится в постоянном движении, которое осуществляется по кровеносной системе.

Кровеносная система состоит из сердца и кровеносных сосудов. Кровеносные сосуды составляют два круга кровообращения - малый и большой. Функциональным центром кровеносной системы является сердце, выполняющее роль двух насосов. Один (правая сторона сердца) продвигает кровь по малому кругу кровообращения, второй (левая сторона сердца) - по большому кругу кровообращения. В каждом круге кровообращения сеть кровеносных сосудов состоит из крупных сосудов артерий, по которым кровь движется в сторону от сердца. По мере удаления артерии ветвятся на более мелкие сосуды - артериолы, которые в свою очередь делятся на тончайшие кровеносные сосуды -капилляры. 
Обмен веществ между кровью и тканями происходит на всем протяжении капилляров. Далее из капилляров кровь переходит в венулы мельчайшие венозные сосуды, из них — в вены и возвращается в сердце.

Сеть сосудов большого круга кровообращения пронизывает все ткани всех органов и частей тела человека. Продвигаясь по капиллярам большого круга кровообращения, кровь превращается из артериальной в венозную: она отдает тканям кислород и питательные вещества, одновременно насыщаясь углекислым газом и продуктами распада, которые переносит к органам выделения, а также выполняет другие функции.

Сосудистая сеть малого круга кровообращения проходит только легкие, где кровь превращается из венозной в артериальную, т.е. отдает в полость легких углекислый газ и насыщается кислородом.

Физическая работа способствует общему расширению кровеносных сосудов, нормализации тонуса их мышечных стенок, улучшению питания и повышению обмена веществ в стенках кровеносных сосудов. При работе окружающих сосуды мышц происходит массаж стенок сосудов. Кровеносные сосуды, не проходящие через мышцы (головного мозга, внутренних органов, кожи), массируются за счет гидродинамической волны от учащения пульса и за счет ускоренного тока крови. Все это способствует сохранению эластичности стенок кровеносных сосудов и нормальному функционированию сердечнососудистой системы без патологических отклонений.

Напряженная умственная работа, малоподвижный образ жизни, особенно при высоких нервно-эмоциональных напряжениях, вредные привычки (курение, потребление алкоголя) вызывают повышение тонуса и ухудшение питания стенок артерий, потерю их эластичности, что может привести к стойкому повышению в них кровяного давления и, в конечном итоге, к гипертонической болезни. 
Потеря эластичности кровеносных сосудов, а значит, повышение их хрупкости и сопутствующее этому повышение кровяного (артериального) давления могут привести к разрыву кровеносных сосудов. Если разрыв происходит в жизненно важных органах (сердце, головной мозг и др.), то наступает тяжелое заболевание или скоропостижная смерть.

Закон перераспределения крови в организме, заключается в том, что кровь направляется в те органы и системы органов, которые в данный момент усиленно работают. Если же человек находится долгое время в неподвижном положении (стоит, сидит, лежит), то это приводит к длительным застойным явлениям в системе кровообращения и нарушению питания тканей неработающих органов или частей тела.

Поэтому для сохранения здоровья и работоспособности необходимо активизировать кровообращение с помощью физических упражнений, в том числе и в режиме учебного дня студента (физкультминутки, физкультпаузы).

Особенно полезное влияние на кровеносные сосуды оказывают занятия циклическими видами упражнений: бег, плавание, бег на лыжах, на коньках, езда на велосипеде и т.п.

Сердце - главный центр кровеносной системы, представляющий полый мышечный орган, обильно снабженный кровеносными сосудами, совершающий ритмические сокращения, работающий по типу насоса, благодаря чему происходит движение крови в организме. Сердце работает автоматически под контролем ЦНС.

Сердце делится на левую и правую половины непроницаемой перегородкой. Правая половина перекачивает венозную кровь в малый круг кровообращения, левая - артериальную кровь в большой. Поперек сердце разделено на предсердия, которые находятся сверху, и на желудочки. Эти четыре камеры попарно соединены перегородкой, имеющей клапаны: правое предсердие - с правым желудочком, левое - с 
левым. Клапаны сердца, а также клапаны у выхода крови в аорту (в большой круг кровообращения) и в легочную артерию (в малый круг кровообращения) обеспечивают движение крови в одном направлении из предсердий в желудочки, а из желудочков — в артерии.

Размеры сердца зависят от возраста, размеров тела, пола и двигательной активности человека. Объем сердца у мужчин - 700-900 cм³, у спортсменов - может достигать 1400-1500 $\mathrm{cm}^{3}$. Средние размеры сердца взрослого мужчины представлены в таблице.

Толщина стенок отдельных камер сердца неодинакова и зависит от мощности производимой работы. Стенки предсердий имеют толщину 2-3 мм, так как они без особого напряжения перекачивают кровь в нижележащие желудочки. Стенки правого желудочка несколько толще (5-8 мм), так как он должен преодолевать сопротивление сосудов малого круга кровообращения. Левый желудочек имеет самые толстые стенки (10-15 мм). Нагнетая кровь в большой круг кровообращения, он преодолевает сопротивление густо разветвленной сосудистой сети.

У женщин размеры сердца несколько меньше.

Размеры и масса сердца увеличиваются в связи с утолщением стенок сердечной мышцы и увеличением его объема в результате физической тренировки, систематических занятий физическими упражнениями и спортом. Такие изменения повышают мощность и работоспособность сердечной мышцы.

Важным показателем работы сердца является количество крови, выталкиваемое одним желудочком сердца в сосудистое русло при одном сокращении. Этот показатель называется систолическим объемом крови (систола - сокращение). Систолический объем (мл) в покое равен: у нетренированных — 60 , у тренированных - 80; при интенсивной мышечной работе: у нетренированных - 100-130, у тренированных людей — 180-200. Вторым важным показателем является минутный объем крови, 
т.е. количество крови, выбрасываемое одним желудочком сердца в течение минуты. В состоянии покоя минутный объем крови составляет в среднем 4-6 л. При интенсивной мышечной деятельности он повышается у нетренированных до 18-20 л, у тренированных людей - 30-40 л.

В положении лежа и при быстрой ходьбе сердце нетренированного человека для того, чтобы обеспечить необходимый минутный объем крови, вынуждено сокращаться с большей частотой, так как систолический объем у него меньше.

При быстром беге сердце нетренированного человека, имея недостаточный систолический объем крови, даже при ЧСС 200 ударов в минуту (предельная возможность) не может обеспечить минутный объем в 30 л крови, который необходим человеку при быстром беге. Поэтому нетренированный человек через несколько минут, а иногда и секунд после начала интенсивного бега, чувствует большое утомление и прекращает бег. Если же человек находится в условиях, когда прекратить бег невозможно и продолжает его, - наступает обморочное состояние.

Сердце тренированного человека может показывать удивительную работоспособность. При интенсивной физической работе систолический объем двух желудочков равен 400 мл (200+200), при ЧСС 200 ударов в минуту минутный объем крови может возрастать до 80 л.

Долго ли сердце может выдержать такую работу? При марафонском беге (42 км 195 м), например, сердце тренированного человека, спортсмена-марафонца, сокращается с частотой 170-190 раз в минуту, производит 20 тыс. сокращений.

При обследовании лыжников-гонщиков, участников соревнований на дистанции 100 км было обнаружено, что за время прохождения дистанции (8 ч 22 мин) сердце спортсмена перекачало 35 т крови - целую железнодорожную цистерну! 
И сердце при правильной тренировке от такой работы не изнашивается, а, наоборот, укрепляется. Здесь действует закон живых тканей: чем больше берешь (в разумных пределах), тем больше остается. Этому закону есть физиологическое обоснование. Секрет высокой работоспособности сердца тренированного человека - в сохранении строгого ритма работы и в том, что мышца тренированного сердца более густо пронизана кровеносными сосудами. Следовательно, в сердце лучше осуществляется питание мышечной ткани и ее работоспособность успевает восстанавливаться во время кратчайших пауз сократительного цикла.

ЧСС, или артериальный пульс, является весьма информативным показателем работоспособности сердечнососудистой системы и всего организма.

В процессе спортивной тренировки частота пульса в покое (утром, лежа, натощак) со временем становится реже за счет увеличения мощности каждого сердечного сокращения.

Урежение пульса, если оно не связано с заболеванием, увеличивает абсолютное время паузы в работе сердца, во время которой сердечная мышца отдыхает.

Средние значения ЧСС (уд./мин) для мужчин:

нетренированных 70-80;

тренированных 50-60.

Средние значения ЧСС (уд./мин) для женщин:

нетренированных 75-85;

тренированных 60-70.

Кровяное давление - давление крови внутри кровеносных сосудов на их стенки. Измеряют кровяное давление в плечевой артерии, поэтому его называют артериальным давлением (АД), которое является также весьма информативным показателем состояния сердечнососудистой системы и всего организма. 
Различают максимальное (систолическое) артериальное давление (АД), которое создается при систоле (сокращении) левого желудочка сердца, и минимальное (диастолическое) АД, которое отмечается в момент его диастолы (расслабления).

Пульсовое давление (пульсовая амплитуда) — разница между максимальным и минимальным АД. Давление измеряется в миллиметрах ртутного столба (мм рт. ст.).

В норме для студенческого возраста в покое максимальное АД находится в пределах 100-130; минимальное - 65-85, пульсовое давление - 40-45 мм рт. ст.

Стойкое повышение максимального АД в покое до 140-150 мм рт. ст. и более свидетельствует о гипертонической болезни, которая почти всегда является следствием снижения эластичности стенок кровеносных сосудов. Реакция АД представлена в таблице.

Пульсовое давление при физической работе увеличивается, его уменьшение является неблагоприятным показателем (наблюдается у нетренированных людей). Снижение давления может быть следствием ослабления деятельности сердца или чрезмерного сужения периферических кровеносных сосудов.

Полный кругооборот крови по сосудистой системе в покое осуществления за 21-22 секунд, при физической работе - за 5 секунд и меньше.

При физической работе в результате увеличения скорости движения крови по сосудистой системе значительно повышается снабжение тканей тела питательными веществами и кислородом.

Особенно полезны циклические физические упражнения в условиях гигиенически чистого открытого воздуха, например, в лесопарке.

После прохождения через капилляры кровь попадает в вены и по ним возвращается к сердцу. Движение крови по венам затруднено, 
во-первых, по причине их удаленности от сердца и падения в них кровяного давления до 15-5 мм рт. ст., во-вторых, в большинстве случаев кровь движется по венам вверх против действия силы тяжести.

В венах имеются клапаны, обеспечивающие движение крови только по направлению к сердцу.

При длительном неподвижном положении тела венозная кровь, бедная питательными веществами и кислородом и насыщенная продуктами распада клеток, под влиянием силы тяжести может скапливаться (застаиваться) в различных органах и частях тела.

Стенки венозных сосудов тонкие, и скапливание излишнего объема крови в них может привести к деформации и расширению вен [3].

Застойные явления венозной крови вредно отражаются на функциях соответствующих органов в целом.

При динамической циклической мышечной работе движению крови в венах способствует дыхательный насос. Действие дыхательного насоса заключается в том, что при вдохе давление в грудной клетке понижается и даже может достигать отрицательных значений. Поэтому при учащении дыхания во время динамических, преимущественно циклических движений, увеличивается присасывающее действие грудной клетки, что способствует продвижению крови по венозным сосудам к сердцу.

При статических усилиях, сопровождающихся натуживанием, давление внутри грудной клетки, наоборот, повышается, что затрудняет кровообращение и снижает приток крови к сердцу по венам. В результате уменьшения объема крови, выбрасываемой в сосудистое русло, снижается АД, ухудшается кровоснабжение всех органов. Длительное или сильное натуживание резко ухудшает кровоснабжение головного мозга, что может привести к обморочному состоянию.

\section{Контрольные вопросы}


1. Гомеостаз - это....

2. Организм - это....

3. Почему кости детей более эластичны и упруги?

4. Посредством чего кости скелета соединяются между собой?

5. К какому виду мускулатуры относятся скелетные мышцы?

6. Сколько мышц насчитывается у человека?

7. Какие волокна мышц обладают более быстрой сократительной способностью?

8. На что расщепляется гликоген при анаэробных процессах образования энергии?

9. Что образуется при окислении углеводов и жиров?

10. Какой процесс энергообразования обладает большими возможностями во времени?

11. Какую функцию осуществляют клетки крови - эритроциты?

12. Какой пульс считается нормальным для здорового взрослого человека?

13. Какое кровяное давление является нормой у здорового человека в возрасте 18-40 лет?

14. Какое воздействие оказывают систематические занятия физическими упражнениями на дыхательную мускулатуру?

15. Какой процент глюкозы, образуемой печенью, потребляется головным мозгом?

16. Укажите наиболее эффективную форму отдыха при умственном труде.

17. От чего защищает организм такое функциональное состояние, как утомление?

18. До какого уровня восстанавливаются энергетические ресурсы в восстановительном периоде после физической нагрузки?

19. Когда лучше тренироваться, учитывая биологические ритмы? 
20. К чему приводит пониженная двигательная активность?

21. Какова продолжительность работы в зоне умеренной мощности?

22. Как отличаются расходы энергии в покое у тренированных и нетренированных людей?

23. На что указывает урежение пульса в покое (брадикардия) у тренированных людей?

24. В каких видах спорта наблюдается тесная связь между максимальным потреблением кислорода (МПК) и тренированностью?

25. Какова норма потребления белков в день для взрослого человека?

26. Что является главным источником энергии в организме?

27. Когда преимущественно используются жиры как источник энергии при физической деятельности?

28. Каково основное значение витаминов для организма?

29. Сколько калорий необходимо потреблять в течение рабочего дня (8-10 ч) мужчине, занимающемуся умственным и физическим трудом?

30. Какое количество энергии необходимо затрачивать ежедневно для нормальной жизнедеятельности?

31. Какова причина «гравитационного шока»?

32. Физические упражнения какого характера оказывают наиболее эффективное воздействие на сердечно-сосудистую систему?

33. Какова причина так называемой «мертвой точки»?

34. Как можно ослабить проявление «мертвой точки»?

35. Какие меры способствуют качественной готовности студентов к активной учебной работе?

Тема 5. Психофизиологические основы учебного труда и интеллектуальной деятельности. Средства физической культуры в регулировании работоспособности 


\section{План:}

5.1. Основные понятия.

5.2. Особенности учебного труда студентов.

5.3. Формирование профессионально важных качеств средствами физической культуры, спорта и туризма.

5.4. Особенности интеллектуальной деятельности студентов.

\section{1. Основные понятия}

Психофизиологическая характеристика труда - трудовые процессы ведутся в определенном направлении, планируются заранее, связаны с конкретными заданиями, выполнение которых требует определенных психофизиологических энергозатрат, соответствующих уровней мышления умозаключений для получения конечного результата, имеющего общественное значение (обучение, самообучение, открытие, изобретение, рационализация и т.д.).

Работоспособность - сочетание соответствующих возможностей человека, обладающего специальными знаниями, умениями, навыками, физическими, психологическими и физиологическими качествами, совершать целенаправленные действия, формировать процессы мыслительной деятельности.

Утомление - объективное состояние организма, при котором в результате длительной напряженной работы снижается уровень работоспособности, дальнейшие процессы деятельности характеризуются отсутствием творческих начал, преобладанием «шаблонного» мышления и т.п.

Усталость - субъективное состояние индивидуума, для которого характерны резкие кратковременные снижения уровня работоспособности; 
выполнение последующих трудовых актов требует волевых усилий и использования скрытых резервных возможностей организма.

Рекреация (лат. - восстановление) - широкое понятие, связанное с отдыхом, восстановлением сил, использованием природных возможностей И Т.П.

Релаксация (лат. - ослабление, успокоение) - состояние покоя, расслабленности в результате снятия напряжения. [5]

\section{2. Особенности учебного труда студента}

Одна из важнейших задач высшей школы - создание условий для максимальной реализации возможностей интеллектуальной деятельности студенческой молодежи.

Согласно великому Аристотелю, «хороший вождь должен обладать «Этосом», «пафосом», «логосом». Известно, что «Этос» - высокая нравственность, источник убеждать в своей правоте, «пафос» способность затрагивать чувства людей, «логос» - умение разумно обосновать свои поступки и заставлять думать людей

Понимая, что вуз - не школа, вуз не обучает, вуз создает условия для того, чтобы учиться тому, естественно, у кого хватит сил и возможностей, чтобы самопознать себя, объективно развить качества, умения, навыки, наконец, состояние здоровья, высокий уровень умственной и физической работоспособности, интеллекта, культуры, невольно задаешь вопрос: «Хватит ли ваших сил, уважаемые студенты-первокурсники, чтобы все освоить, усовершенствовать и реализовать во благо?» Профессионально заявляю: «Хватит. Хватит, если перед любым начинанием и его результатом будет слово «Сам!». 
Известно, что здоровье человека на $45-50 \%$ зависит от условий образа жизни, избранного стиля жизни, четко связанных с формированием граней личности.

Каждый вуз имеет свою, рожденную им же и постоянно совершенствующуюся информационно-воспитательную среду. Ее многокомпонентность и положительное влияние на студента, особенно первокурсника, корреляционно зависит от уровня педагогического мастерства преподавателей до наиглавнейшего компонента - вузовской (не школьной «физры») физической культуры, спорта, существенно сокращающей период адаптации недавних школьников к условиям пребывания в вузе с его «мягкими» на первых порах формами и видами обучения в течение семестра и неизмеримо жесткими по отношению к организму, порой еще недостаточно окрепшему, в периоды зачетов и экзаменов.

Такие термины, как «самоуправление», «аутогенный менеджмент» - не только дань моде, но и важные волевые моменты, основа которых: постановка целей, планирование своей деятельности, распределение времени и многое другое, что связано с изменением уклада, стиля, образа жизни

Гармоничное сочетание интеллекта, физических и духовных сил высоко ценилось человеком на всем протяжении его развития и формирования. Вуз предоставляет такую возможность.

Особо следует сказать об адаптации к вузовским формам и видам обучения. Подчеркнем, что студенту-первокурснику, резко перешедшему границу между условиями обучения в школе и вузе, важно сократить этот период, который может длиться и семестр и два-три года. Просматривается четкая закономерность сокращения времени адаптации у тех, кто коммуникабелен, увлечен спортом, общественной работой, любой формой деятельности с высоким уровнем ответственности. 


\section{Этому способствуют:}

активные средства физической культуры, игровые виды спорта, туризм, альпинизм, спортивное ориентирование, скалолазание и другие виды целенаправленной физической занятости;

массовые оздоровительно-спортивные мероприятия, в которых студент - участник, организатор, помощник и т.п.;

$>$ разумное планирование своей жизни на ближайшие 3-5 лет в виде реально обоснованной программы самосовершенствования, основные положения которой нацелены на укрепление здоровья, повышение интеллекта, освоение избранной профессии.

Известно, что человек рождается только с задатками тех природных качеств, которые определяют красоту тела и соразмерность, согласованность движений, физическую силу, гармоничность развития. Активное развитие, совершенствование и формирование этих природных дарований - это процесс самопознания, самоутверждения, становления личности, и «ничто так не истощает и не разрушает человека, как продолжительное физическое бездействие» (Аристотель) [16].

Не менее важно и использование средств физической культуры, спорта в психологической подготовке будущего специалиста. Именно спорт, физическое воспитание ставит студента (пока студента!) в те условия, которые формируют его психологическую готовность к профессиональным негативным воздействиям. Австралийский психолог Алан Пиз доказал, что с помощью слов, вербально, мы передаем только 7\% информации, 93\% приходятся на интонацию, мимику, жесты, бессознательные телодвижения. Только наличие сильной воли, умение сохранять самообладание могут позволить скрыть свое психологическое состояние.

Утомление необходимо рассматривать как временное ухудшение функционального состояния организма, основные признаки которого: 
$>$ резкое снижение работоспособности;

$>$ изменение физиологических функций;

изменение внешних признаков поведения.

Способность человека выполнить конкретную умственную деятельность в заданных параметрах эффективности определяется как работоспособность, основу которой составляют определенные психофизиологические свойства, психологические качества индивида и специальные знания, умения, навыки.

Наиболее типичные изменения работоспособности студентов связаны c учебной нагрузкой, расписанием занятий, занятостью научно-исследовательской, профессиональной деятельностью как дополнительными факторами. К ним следует отнести и особенности использования средств физической культуры для оптимизации работоспособности [29].

Принятые системой образования рекреации: кратковременные перерывы между занятиями, еженедельный, зимний и летний каникулярный отдых, временное пребывание целевого характера в профилакториях, санаториях, академический годовой отпуск нацелены на восстановление оптимального соотношения основных нервных процессов в коре головного мозга и связанную с этим умственную работоспособность. Для работы мозга в нормальном режиме необходимы импульсы, поступающие от разных систем организма, при этом пятьдесят и более процентов от всех импульсов принадлежит мышцам.

Движения мышц, создающие громадное количество импульсов, способствуют образованию замкнутых циклов возбуждения, отличающихся высокими уровнями стойкости, инертности.

Так, после прекращения физической работы человек сразу отключается от нее. При умственной деятельности интенсивная работа мозга продолжается. Нервная система полностью не реабилитирована. 
Экспериментально доказано, если человек после физической работы не получил полного отдыха, его тоническое напряжение мускулов увеличивается: переутомленный мозг мобилизует свои возможности для борьбы с переутомлением мускулатуры.

Для умственной деятельности необходим не только тренированный мозг, но и тренированное тело.

\section{3. Формирование профессионально важных психических качеств средствами физической культуры и спорта}

$\begin{array}{rlllll}\text { Внимание. } & \text { Отдельные } & \text { качества } & \text { внимания имеют } & \text { много } \\ \text { специфического, в связи с этим при их формировании и }\end{array}$ совершенствовании используются различные педагогические приемы.

Объём и распределение внимания формируются как деленный навык одновременного выполнения нескольких действий, близких по своей психофизиологической структуре профессиональным действиям, выполняемым в условиях высокого темпа работы. При этом постепенно увеличивают количество воспринимаемых объектов и явлений, расстояние между ними и темп восприятия.

Переключение внимания формируется в процессе физического воспитания несколькими путями: упражнениями на переключение внимания с объекта на объект с предварительным усвоением техники и «маршрутов» переключений; упражнениями с выделением наиболее важных объектов из второстепенных; тренировками в быстроте переключения внимания с объекта на объект.

Концентрация внимания развивается путем воспитания и самовоспитания установки на внимание.

Устойчивость внимания обеспечивается выработкой волевых качеств и созданием путем тренировки определенной физиологической базы для 
проявления устойчивого внимания, в частности, выносливости глазодвигательного аппарата.

Большие возможности для качеств внимания представляют гимнастические и строевые упражнения.

Эффективным универсальным средством развития внимания являются спортивные игры с мячом. Это объясняется тем, что действия в них требуют высокого уровня проявления различных качеств внимания. Так, волейболисту в процессе игры приходится одновременно воспринимать более 10 объектов и их элементов. Например, принимая мяч, он одновременно определяет расстояние до мяча и игроков, следит за перемещением своих игроков и игроков противника, выбирает способ и усилие для передачи мяча и т.д. Кроме того, волейболисту во время игры приходится постоянно моментально менять объекты, на которые направлено внимание. Сделав передачу для нападающего, он переключает свое внимание на страховку, прием и т.д. Только за одну секунду внимание волейболиста переключается поочередно на 3-6 объектов. Длительность игры, разнообразие тактических ситуаций требуют устойчивости внимания. Все это приводит к тому, что уже сами по себе занятия волейболом способствуют развитию качества внимания. Например, объем внимания у волейболистов больше, чем у гимнастов, борцов, пловцов на 25-31\%.

Упражнения на внимание

Упражнения для развития объема и распределения внимания: бег, езда на велосипеде по шоссе; бег в среднем и быстром темпе с одновременным выполнением заданий для рук и ног (например, эстафетный бег); бег под гору между деревьями; прыжки в длину с разбега; метание легкоатлетических снарядов; выполнение вольных гимнастических упражнений на координацию движений рук и ног; жонглирование двумя и более мячами; ходьба по двум параллельно поставленным гимнастическим скамейкам [8]. 


\section{Оперативное мышление}

Эффективными путями развития оперативного мышления в процессе физического воспитания являются: использование элементов тактической подготовки, широкое применение на занятиях спортивных игр и единоборств и тренировка в этих видах; введение определенной системы педагогических воздействий, специально направленных на формирование качества.

Существенный эффект оказывают:

$>$ обучение (по принципу проблемного обучения и поэтапного формирования умственных действий) приемам оперативного мышления на материале, специфичном для физического воспитания;

$>$ упражнения, направленные на решение различных двигательных алгоритмических (решаемых по определенной схеме) и эвристических (требующих творческих усилий мысли) задач по типу упражнений для развития тактического мышления игровика, бегуна на средние дистанции, борца;

упражнения на развитие наблюдательности, памяти, восприятия, внимания, воли и других психических процессов, связанных с быстрым мышлением.

Упражнения на оперативное мышление

1. Выполнение различных тактических алгоритмических и эвристических заданий для бегуна на средние дистанции, игровика, борца, фехтовальщика, боксера.

2. Эстафета с решением внезапно возникающих алгоритмических и эвристических задач (легкоатлетические эстафеты с общей зоной передачи, эстафеты с преодолением препятствий, с ведением, переноской мяча).

3. Преодоление незнакомых полос препятствий на время.

4. Бег под гору, езда на велосипеде, скоростной спуск на лыжах, санях по закрытому маршруту. 
5. Спортивные игры (бадминтон, баскетбол, бейсбол, волейбол, ручной мяч, русская лапта, теннис, настольный теннис, мини-футбол, хоккей, велобол, велополо, мотобол).

6. Игра в бадминтон, волейбол, теннис через закрытую сетку.

7. Ориентирование на местности.

5. Игра в шахматы «блиц». Продолжительность партии - 3-10 мин. На каждый ход -3-10 с. Время на обдумывание и партию постепенно сокращается.

Эмоциональная устойчивость.

В процессе профессионально-прикладной физической подготовки эмоциональная устойчивость обеспечивается путем:

1) приобретения опыта волевого поведения в условиях эмоциональной напряженности, совершенствования физиологических процессов адаптации к стресс-факторам;

2) выработки навыков, умений, привычек, саморегуляции эмоциональной напряженности [24].

Для решения первой задачи наиболее эффективными средствами являются упражнения, моделирующие различные стрессовые ситуации и требующие мобилизации всех сил занимающихся для эффективного выполнения поставленной задачи в заданных условиях.

Решение второй задачи осуществляется путем упражнений в приемах изменения соматических и негативных проявлений эмоций (контроля и регуляции мимических мышц, мышц скелетной мускулатуры, специальных дыхательных упражнений) и способах отвлечения от эмоций, самовнушения-самоубеждения.

Упражнения, направленные на приобретение опыта волевого поведения в условиях эмоциональной напряженности

1. Бег с горы по сложному маршруту. 
2. Эстафета с выполнением двигательных задач, требующих проявления смелости, решительности.

3. Выполнение различных двигательных задач на высоте (гимнастическом бревне, гимнастической стенке, специальной площадке).

4. Прыжки в воду с вышки.

5. Прыжки на батуте (с выполнением сложных по координации движений).

6. Командные спортивные и подвижные игры (баскетбол, волейбол, ручной мяч, регби, борьба за мяч, хоккей и др.).

7. Скоростной спуск на лыжах по сложному маршруту.

8. Скалолазание.

Волевые качества. Методической основой волевой подготовки является система воздействий, направленных на воспитание конкретных волевых проявлений личности, накопление ею опыта волевого поведения, создание хорошей функциональной, физиологической и морфологической базы для волевых проявлений. Основными средствами для решения этих задач служат физические упражнения, виды спорта, требующие преодоления трудностей, адекватных трудностям производства.

Инициативность. Нормирование этого волевого качества на занятиях физической культурой и спортом осуществляется главным образом за счет накопления опыта инициативного поведения. С этой целью действенными являются следующие приемы и средства:

1) выполнение физических упражнений на занятиях одним из многих способов по личной инициативе;

2) самостоятельное проведение тренировочных занятий с группой;

3) соревнования с другими студентами на оптимальное решение двигательной задачи;

4. самостоятельный выбор тактического плана выступления на соревнованиях; 
5. организация физкультурных и спортивных мероприятий в группе по личной инициативе;

6. спортивные игры;

7. единоборства;

8. эстафеты;

9. личные соревнования.

Смелость и решительность. Формированию этих качеств в наибольшей степени способствуют упражнения, содержащие элементы известного риска и требующие преодоления чувства боязни и колебания.

Упражнения на смелость и решительность

1. Бег под крутую горку с преодолением препятствий.

2. Прыжки в глубину и соскоки с гимнастических снарядов.

3. Ходьба и бег с закрытыми глазами.

4. Прыжки через препятствия и гимнастические снаряды.

5. Упражнения на батуте: прыжок на живот - прыжок на ноги, сальто вперед и назад в группировке, согнувшись.

6. Преодоление специальных полос препятствий.

7. Игра в регби по упрощенным правилам с силовыми элементами.

8. Акробатические прыжки.

9. Прыжки в воду.

10. Прыжки-падения на землю, пол.

11. Быстрое нападение в играх.

12. Боксерский поединок с сильным противником.

13. Скалолазание.

Стойкость. Наиболее действенным средством формирования этого качества в процессе физического воспитания являются упражнения, которые содержат элементы преодоления значительных внешних и внутренних трудностей, выполняются в неблагоприятных метеорологических условиях, в большом объеме, требуют значительного 
нервного напряжения. При воспитании стойкости целесообразно использовать приемы, усиливающие эффект применяемых средств: искусственное наращивание усилий, тренировку в группе, соревновательный метод, внесение в тренировку эмоционального фактора, применение технических средств.

Во время формирования стойкости нужно тренировать не только волевое усилие, но и физиологическую базу усилия. В этом случае необходимо строго соблюдать принцип постепенности наращивания нагрузок и адекватности их возможностям организма. В противном случае может произойти истощение физиологической базы, что, в конечном счете, отразится на волевом действии.

Упражнения на стойкость

1. Медленный длительный бег в сложных метеорологических условиях - до 3 ч.

2. Темповый кроссовый бег - до 3 ч.

3. Кроссовый бег по сложной, изобилующей различными препятствиями местности.

4. Тренировка в кроссе и марш-броске при неблагоприятных метеорологических условиях: в дождь, снегопад при сильном ветре, высокой и низкой температуре.

5. Соревнования в марш-броске, беге на 8, 10, 20, 30 км, 42 км 195 м.

6. Плавание на дальность.

7. Преодоление специальных полос препятствий.

8. Борьба с более сильным противником.

9. Однодневные и многодневные пешие и лыжные турпоходы.

10. Шлюпочный поход на 20 км и более.

11. Лыжный переход, велопробег.

12. Задержка дыхания на время на вдохе или выдохе [5]. 


\section{4. Особенности интеллектуальной деятельности студентов}

Однажды Аристотеля спросили: «Насколько люди воспитанные превосходят неучей?». «Настолько, насколько живые превосходят мертвых», был ответ. Великий философ, ученик Платона и учитель Александра Македонского, конечно же, под людьми воспитанными подразумевал гармонично подготовленных - умственно и телесно, способных мыслить и творить, обладающих высокими критериями творческого мышления, обладающих интеллектуальным и личностным потенциалом.

Определить, что такое интеллект без понимания таких понятий, как «мышление», «эрудиция», невозможно. Человек вольно или невольно, познавая реальности мира, вынужден сравнивать, анализировать и синтезировать воспринимаемые им явления и предметы, моделировать и умозаключать, создавать гипотезы и теории. Далеко не все, что познается органами чувств - объективно, да многое и недоступно нашим несовершенным органам, трансформированными цивилизацией, и тогда непосредственное восприятие окружающего мира осуществляется мыслительной, умственной сферой. Реальный мыслительный процесс познания, умственная целенаправленная активность на основе алгоритма действий и личностных возможностей, и есть мышление. У разных людей умственные способности к интеллектуальной работе, естественно, существенно разнятся. Умственные возможности продуктивно мыслить, перерабатывать и осознавать сложнейшую информацию составляют сущность интеллекта, мышление же - процесс его действия. Мыслительная деятельность человека невозможна без постоянного информационного пополнения.

Понятия «эрудиция» и «интеллект» относятся друг к другу, как понятия «количество» и «качество». Чем больше получает человек 
информации, тем интенсивнее она перерабатывается и усваивается. Систематизированный информационный объем, усвоенный человеком, то есть количество знаний, необходимых для его функционирования, называется эрудицией. Интеллект, на высших уровнях его развития, сегодня рассматривается как способность к нетрадиционному, творческому мышлению, нахождению новых возможностей решения проблем. Человеческий интеллект динамичен, обладает способностью улучшаться и ухудшаться, что зависит от умственных способностей самого человека. Внутренняя структура интеллекта характеризуется гармонично организованными, слитыми в единое целое для действия, уровнями, одновременно являющимися и формами существования интеллекта: здравый смысл, рассудок, разум.

Здравый смысл - наиболее древняя сцементированная повседневной жизнедеятельностью, очевидностью связей предмета и явления, форма практического мышления, предположительно связанного с функционированием правого полушария головного мозга. Здравый смысл - своеобразный фильтр для выбора направлений мышления в виде здравых практических суждений, природной смекалки, базирующихся на наглядности.

Рассудок - продукт отражения и воспитания — он формируется не на базе чувственной информации, реалий бытия, а на основе усвоенных ранее знаний практического и научного характера, действующих по регламентированным предписаниям, правилам, нормам, схемам и т.п. Рассудок проявляется, как способность производить себе подобные алгоритмы действий, ему присущи автоматизм, запрограммированная деятельность, консерватизм. Деятельность рассудка увязывается с функционированием левого (логического) полушария мозга, естественно с языком в рамках грамматических форм. 
В нормально развитом интеллекте здравый смысл и рассудок находятся в гармонии функциональных действий: деятельность одного как бы притормаживается и контролируется деятельностью другого.

Разум - высшая умственная способность человеческого мышления, основа которого- все ценное от здравого смысла и рассудка, преобразованное в новое качество интеллекта- способность к творческому мышлению. Разуму присущи глубинное проникновение в сущность явлений, разрушения застывших схем, логических структур, создание новых матриц, установления закономерных связей между вещами и явлениями, творческое видение, целевая направленность в будущее, элементы интуиции. ІІолагают, что разумное мышление связано с работой лобных отделов головного мозга обоих полушарий [12].

Деятельность человеческого мозга не зависит от веса, объема: у философа Канта мозг весил менее одного килограмма, писатель Тургенев обладал мозгом весом 2200 г. Самый большой мозг имел... идиот. Объем мозга не определяет ум, интеллект человека. Главный показатель количество функциональных связей, конкретно - образование контактов между нейронами в структурах мозга. А их насчитывается до 10000 на одном нейроне. Но в лучшем случае задействовано лишь 500-600.

Мозг не стареет, не изнашивается - колоссальный потенциал не предоставляет ему такой возможности. Оказывается трафаретное представление об изменениях нашего мозга со времен древнего человека научно не подтверждается. Обратимся к мнению нейрофизика, доктора биологических наук, академика РМТА, профессора Г.А. Кураева: «Должен вас огорчить - мозг совсем не изменился. Человек сегодня апеллирует большим количеством знаний, поэтому кажется, что он стал умнее. А по структуре, деятельности - все, как у предков: два полушария, левое речевое, в нем центр зрительной, слуховой, моторной речи, и более того, оно управляет правой рукой. А правое полушарие - субдоминантное, 
немое, подчиняющееся. И если удалить какое-то количество мозга справа, большой беды не будет. Сегодня в мире живут 160 известных людей, которые имеют разрушенную кору правого полушария, и их мозг функционирует нормально. Пастер стал великим ученым, несмотря на полученную в юности травму, в результате которой кора правого полушария была полностью атрофирована».

Нет единого мнения среди психогенетиков и в вопросе, является ли интеллект врожденной способностью или определяется влиянием окружающей среды, обучением, воспитанием, эрудицией. Одни считают, что умственные способности на 10\% определены генофондом, на 20\% социальной сферой. Другие полагают, что 75\% определяется наследственностью, 25\% - средой, $13 \%$ - влиянием внутрисемейных факторов, 12\% - межсемейных. Большинство ученых едины в том, что формирование интеллекта проходит под влиянием двух основных факторов: наследственности и социальной среды, что рождает новое качество мышления — человеческий интеллект, реализация которого в социальной жизни возможна при наличии нижеследующих составляющих (О.А. Андреев, Л.Н. Хромов, 1997).

1. Физическое, психическое духовное здоровье. Уверенность в своих силах. Критичность к себе.

2. Здравый смысл. Желание и умение постоянно учиться, в том числе и на подсознательном уровне.

3. Активное использование алгоритмов умственной деятельности, владение техникой быстрого чтения, развитое внимание и память.

4. Профессионализм и компетентность в конкретной области знаний. Развитое логическое мышление.

5. Развитие воображения и интуиции. Способность к парадоксальному мышлению.

6. Трудолюбие. Высокий уровень обязательности. 
7. Развитая рефлексия - умение видеть события и себя со стороны: коммуникабельность и открытость в общении [9].

Краткий комментарий к вышеизложенному. Никогда не забывайте о гармоничном развитии!

Духовное здоровье не дает достижения ума использовать людям, обществу во зло, а не во благо. Исходные данные интеллектуального потенциала личности - постоянное желание и умение учиться. Эрудиция, пьедестал которой - активное использование алгоритмов умственной деятельности, развитие и совершенствование внимания, памяти, техники быстрого восприятия информации, - энергетика, пища интеллекта.

Все гениальные люди обладали высоким уровнем обязательности основой для реализации себя в жизни. Их достижения были действенной силой в обществе, благодаря умению критично осмысливать свои собственные действия, и наличию таких черт характера, как коммуникабельность и открытость в обращении.

Гениальных людей, оказывается, не более четырехсот, но способных, которые могут работать над совершенствованием своего интеллекта, более 90\%. Именно из их числа рождаются гениальные люди.

У многих народов, а у русского особенно, есть емкие характеристики оценки умственных возможностей нашего мыслительного аппарата. Достаточно вспомнить высказывания о глупом, недалеком человеке: «Не богат умишком», «Ума лишенный», «Ума не хватило» или наши пословицы: «Дурная голова ногам покоя не дает», «Ума нет, считай -калека». И с каким почтением - о человеке мудром, обогащенном знаниями, умениями: «Бог ума ему дал», «У него - ума палата», «Умница», добился чего-то, так «своим умом, да трудом», «Умелец».

Известно, что существует четыре основных разновидности, типа ума (А. Лук, 1979): 
$>$ концептуальный - присущ человеку, способному решать логические, математические, лингвистические задачи;

$>$ социальный - проявляется в межличностных отношения, устанавливающих иерархию целей и ценностных ориентаций;

$>$ эстетический - нацелен на восприятие форм, игнорируя причины и практическую значимость;

$>$ технологический (рабочий) - позволяет представить конечные результаты и технические возможности, силы, средства (включая и собственную мускульную энергию) для выполнения конкретного вида деятельности.

Понятно, что представителей, обладающих стопроцентными качествами того или иного типа ума, не существует. Каждый человек обладает качествами мыслительного аппарата в той или иной степени, что зависит и от генетики, и от влияния окружающей среды, и от способностей человека.

Умственным трудом считают такую работу, которая проходит, ведется в определенном, ограниченном целевыми установками, направлении, по строгому плану, для решения конкретизированных целью задач, имеющих социальное значение: обучение, самообучение, изобретение, рационализация и т. п. (по материалам исследований М.Я. Виленского, А.В. Палладина, В.М. Когана, Ю.И. Евсеева).

Доказано, что умственная деятельность (учебно-трудовая студентов относится именно к этой категории) сопровождается различными изменениями функционального состояния органов и систем организма. Так мозговая ткань использует больше кислорода, чем другие ткани тела, около 20\% (из расчета вес человека - 70 кг, вес головного мозга - 1,5-2 кг, т.е. 2-3\% от веса тела), т.е. 40-50 $\mathrm{cm}^{3}$ в одну минуту. Суточный расход энергии при умственной работе в средних пределах 2800-3000 ккал. По 
сравнению с расходом энергии в состоянии покоя некоторые виды умственного труда требуют повышения энергозатрат:

20. чтение сидя «про себя» — на 16\%;

21. вслух — на $48 \%$;

22. слушание лекций, выполнение (стоя) практических, лабораторных заданий — на 46\%;

23. чтение лекций (стоя), доклады — на 94\%.

Без вмешательства эмоциональных факторов сердечнососудистая система изменяется незначительно, соответственно интенсивности.

Главным же источником энергии для мозга является окислительный процесс обмена глюкозы, потребление которой приблизительно 80 мг в одну минуту. Метаболическая активность зависит от его функциональной деятельности. В состоянии сна накапливаются богатые энергией фосфорные соединения, а при усиленной умственной работе они расщепляются, что проявляется в повышенном гликолизе и усиленном образовании молочной кислоты. Возбуждение ЦНС приводит к увеличению образования аммиака, а угнетение ЦНС - к уменьшению его содержания в мозговой ткани. Изменение некоторых показателей газообмена может характеризоваться напряженностью умственной работы.

Так, наблюдения, проводимые над студентами, прорабатывающими трудный материал (книга, конспект — в период полготовки к экзаменам), привели к следующим результатам: при работе над первыми 8-ю страницами выделение углекислоты повысилось на 12\% (по сравнению с состоянием покоя), после 16 страниц - на 20\%, после 32 страниц - более, чем на $35 \%$ [5].

Представляет интерес и динамика сердечнососудистой системы (CCC). При умственной работе увеличивается наполнение кровью сосудов мозга, происходит сужение периферических сосудов конечностей, расширение сосудов внутренностей, т.е. сосудистые реакции обратны тем, 
которые характерны при мышечной нагрузке. Кратковременный интенсивный умственный труд усиливает частоту сердечных сокращений, особенно, когда работа сопровождается нервно-эмоциональным напряжением, резко разрушающими факторами, условиями дефицита времени (а когда студенту «хватало времени»?!), отрицательного влияния внешних разрушителей и т.П. При долговременной умственной работе частота сердечных сокращений замедляется.

По исследованиям Евсеева Ю.И., показатели пульса в течение семестра, в день экзамена и после него в течение 2-3 дней представлены следующими данными: 70-74 уд./мин, 120-150, 78-82. Изменения наблюдались и с показателями артериального давления: 118/75 мм рт. ст., 170/95 и 128/ 75. Такая закономерность говорит о том, что еще длительное время «рабочая доминанта» не угасает, не исчезает полностью, вызывая утомление. Исследования зарубежных ученых в определенной мере подтверждают эти данные: так, из 145 студентов Оксфорда, прекративших в учебном году занятия в университете из-за болезней, половина оказались психически неполноценными. При обследовании 90 тыс. студентов ФРГ психические и психоневрологические расстройства были обнаружены у 9,5\%. В России более трети студентов страдают заболеваниями нервной системы, более $\quad 20 \% \quad$-гипертоники, $\quad$ менее $\quad 80 \%$ школьников-старшеклассников имеют заметные отклонения в состоянии здоровья и недостаточное физическое развитие. Не менее половины требуют врачебного вмешательства для нормализации своих функциональных возможностей [8].

Таблица 5 - Внешние признаки утомления в процессе умственного труда студентов (по С. Л. Косилову) 


\begin{tabular}{|c|c|c|c|}
\hline & \multicolumn{2}{|l|}{ Утомление } & \\
\hline \begin{tabular}{|c} 
Объект \\
наблюдения
\end{tabular} & незначительное & значительное & резкое \\
\hline Внимание & Редкие отвлечения & $\begin{array}{l}\text { Рассеянное, } \\
\text { отвлечения }\end{array}$ & $\begin{array}{|lr|}\text { Ослабленное; реакции на } \\
\text { новые } & \text { раздражители } \\
\text { (словесные } & \text { указания) } \\
\text { отсутствуют } & \\
\end{array}$ \\
\hline Поза & $\begin{array}{l}\text { Непостоянная, } \\
\text { потягивание ног } \\
\text { выпрямление } \\
\text { туловища }\end{array}$ & $\mid \begin{array}{|lr|}\text { Частая смена поз, } \\
\text { повороты } \\
\text { разные головы в } \\
\text { облокачивание, } \\
\text { поддерживание } \\
\text { головы руками } \\
\end{array}$ & $\begin{array}{|lr|}\text { Стремление } & \text { положить } \\
\text { голову } & \text { на } \\
\text { вытянуться, } & \text { откинуться на } \\
\text { спинку стула } & \\
\end{array}$ \\
\hline Движения & Точные & $\begin{array}{l}\text { Неуверенные, } \\
\text { замедленные }\end{array}$ & $\begin{array}{|lr|}\begin{array}{l}\text { Суетливые движения рук и } \\
\text { пальцев } \\
\text { почерка) }\end{array} \\
\end{array}$ \\
\hline $\begin{array}{l}\text { Интерес } \\
\text { новому } \\
\text { материалу } \\
\end{array}$ & \begin{tabular}{|l} 
Живой \\
задавание вопросовес,
\end{tabular} & $\left|\begin{array}{lr}\text { Слабый } \\
\text { отсутствие вопросов }\end{array}\right|$ & $\begin{array}{l}\text { Полное } \\
\text { интереса, апатия }\end{array}$ \\
\hline
\end{tabular}

При длительном и направленном умственном труде наступает утомление - объективное состояние организма, при котором деятельность внешних органов чувств аномальна: может возникнуть резкое кратковременное повышение или до крайности ослабление реакции организма: почти мгновенное исчезновение из памяти только недавно усвоенного, снижается сила памяти, что ведет к состоянию, когда представления, образы становятся расплывчатыми, «мысли убегают», прекращается желание трудиться, состояние организма длительно не восстанавливается.

Часто состояние утомления смешивают с усталостью субъективным чувством индивидуума, для которого характерны практически все перечисленные выше признаки, но они кратковременны, причины их известны: неудовлетворенность сделанным, неудачи, условия плохой организации мыслительного труда, эмоциональный подъем (к примеру: в день экзамена получение высокой оценки) и т.д. Необходимо особо отметить, что, к примеру, успешная сдача экзамена может еще 
больше мобилизовать студента, и «провал» может привести к депрессивному состоянию.

Умственный труд проходит в условиях недостаточной двигательной активности, что способствует развитию процессов торможения в коре больших полушарий и, как следствие, ухудшение общего самочувствия, пониженная работоспособность, утомление.

Проявление первых признаков значительного, особенно резкого утомления -биологически необходимая защита от развития истощения организма, сигнал для прекращения работы, для рекреации.

Волевым усилием можно заставить организм продолжать работу, что только отдалит (не ликвидирует!) утомление или, что намного опаснее, приведет к состоянию переутомления. Переутомлению присущи постоянное чувство усталости до начала работы, отсутствие интереса, апатия, повышенная неадекватная реакция, головная боль, головокружение, снижение аппетита, снижение веса тела, потливость, снижение сопротивляемости организма инфекциям и т.п [9]

Изменение умственной работоспособности, наблюдение в течение дня, недели, семестра и учебного года отражают соответствующие поставленным целям, задачам корреляционно связанные с состоянием организма периоды врабатывания, стабильной, высокой работоспособности в период ее снижения.

Начало учебного дня не отличается высокой эффективностью учебного труда. Период врабатывания — в пределах 10-30 минут. За этот период в коре головного мозга образуется рабочая доминанта. Важное значение имеет соответствующая установка - мотивация. Период высокой оптимальной работоспособности обычно не превышает 3 часов (1,5-3 часа). Изменения функционального состояния организма соответствуют содержанию, форме, виду, объему учебного труда. Далее наступает период снижения работоспособности или ее продолжение на 
требуемом уровне за счет волевых усилий, в силу созданных условий деятельности. Обратим внимание на приведенный на рис. 1 так называемый «второй подъем» работоспособности при самостоятельной работе. Объяснение этого явления кроется в суточной ритмике и связывается, в основном, с психическим настроением волевого характера.

Любая человеческая деятельность, а интеллектуальная особенно, психологически увязывается с влиянием жизненных, обусловленных требованиями трудового процесса ритмов и свойственных организму биологических колебаний. Для человека наибольшее значение имеют так называемые «суточные ритмы», в процессе которых изменяются более пятидесяти (!) физиологических функций организма. В период бодрствования, активной деятельности показатели функционального состояния сердечнососудистой, эндокринной, мышечной, выделительной и других систем достигают самого высокого уровня, а в период отдыха, сна реализуются на необходимом уровне восстановительные процессы. Чем больше и точнее осуществлен контакт с началом учебно-трудовой деятельности с мобилизацией жизненно важных функций организма, тем продуктивнее будут результаты трудовых действий [24 ].

Достаточно многими исследованиями установлено деление студенческого контингента на студентов, отнесенным к «утреннему» типу, так называемым «жаворонкам», отличающихся наиболее приподнятым настроением, высокой работоспособностью в утреннее и дневное время, и студентов «вечернего» типа — «сов», несколько заторможенных в первой половине дня, высокий уровень работоспособности которых начинается с 17-18 часов.

Из 400 обследованных немецким ученым Хампом было установлено, что у 35\% тип «деловой активности» имеет смысл отнести к «вечерним», 17\% - к «утренним», 48\% — к «аритмичным» типам. Нет единого мнения по вопросу: «Заложены ли эти особенности в генетической программе или 
формируются на протяжении жизненных периодов?». Всегда надо помнить, что любой труд, а умственный особенно, и отдых в своем биоритме залог не только высокой эффективности, но и сохранения высокого уровня здоровья. Идеальный вариант расписания - отдельно для «жаворонков», отдельно для «сов» - составить невозможно и поэтому студенты-«совы», занимающиеся на дневной форме обучения, и студенты-«жаворонки», занимающиеся на вечерней, находятся в условиях высокого уровня мотивации и «волевого синдрома».

Известно, что мотив в деятельности человека - осознанное проявление активности, целенаправленное на выполнение поставленных задач, что подтверждается исследованиями М.Я. Виленского (1992). Студентам предлагалось выполнять вычислительные операции в принудительном темпе. Одни требовали логики мышления, другие были менее сложными.

Условием эксперимента было продолжение работы до предела возможностей каждого испытуемого. В конечном итоге: студенты, проявившие избирательное отношение вследствие интереса, эмоциональности выполняли работу значительно дольше по времени, чем те, у которых этот мотив отсутствовал.

Не менее интересен и результат другого эксперимента, в процессе которого студенты постоянно находились под влиянием воздействия информации о результатах их работы. Качественная эффективность выполняемых действий была лучше у тех, кто такую информацию получал.

Умственная работоспособность студентов изменяется в зависимости от психофизиологического состояния организма до начала работы, особенностями самой работы, ее организацией и другими причинами. Независимо от времени деятельности: будь то академический час, учебный день, неделя, семестр, учебный год, учебный труд характеризуется 
различными периодами эффективности: врабатывания, устойчивой (оптимальной) работоспособностью и периодом ее снижения [12].

Учебный день: период врабатывания до 15-30 минут. Этот период характеризуется образованием рабочей доминанты. Особое значение имеет установка, психологическая настройка. Второй период, длительностью 1,5-3 часа, обладает высокой степенью эффективности, максимального использования функциональных возможностей, изменения в организме, которые адекватны требованиям учебной деятельности. Третий период период полной компенсации начальных признаков утомления волевыми усилиями и положительной мотивацией. Далее наступает период несбалансированной компенсации, нарастает утомление (нарушается работа анализаторов, устойчивость внимания, оперативной памяти и др.). Следующий этап характеризуется прогрессирующим снижением работоспособности, резким снижением продуктивности и угасания рабочей доминанты.

Рабочий день студента не заканчивается аудиторными занятиями: он включает время на самоподготовку. Второй подъем работоспособности объясняется не только суточной ритмикой, но и мотивацией, психологической установкой и использованием «волевого синдрома».

Учебная неделя: период врабатывания - понедельник; вторник-четверг — высокий уровень работоспособности, пятница-суббота — период ее снижения. Естественно, что эта закономерность изменится при вмешательстве различных факторов нервно-эмоционального направления, связанного, например, с выполнением ответственного задания, подготовкой к контрольной, семинару, зачету и т.п.

Работоспособность студентов в течение семестра, учебного года также подчинена изменениям в периодах врабатывания, оптимальной деятельности, снижения. Студенты обычно «входят в форму» (период пребывания) 3-3,5 недели. Работоспособность устойчивого, высокой 
эффективности характера длится приблизительно 10 недель. В декабре в периоды увеличения ежедневной нагрузки до 11-13 часов и более, в сочетании с нервно-эмоциональным состоянием и переживаниями в периоды зачетной и экзаменационной сессий наблюдается снижение работоспособности. Ее высокий уровень достигается психологическим настроем, целевой мотивацией и, естественно волевыми усилиями [24].

Зимние каникулы - период восстановления работоспособности. У спортсменов, в группах организованного активного отдыха работоспособность восстанавливается полностью. В группах отдыха самостоятельными формами - только на $60-70 \%$ от исходных данных. Период врабатывания во втором семестре соответственно - 5-7 дней и 12-16 дней. Устойчиво высокая работоспособность характерна почти до конца апреля. Снижение ее в конце апреля объясняется накоплением в течение учебного года многих отрицательных факторов и их кумулятивным негативным воздействием.

\section{Контрольные вопросы}

1. Какое воздействие на организм студентов оказывает вынужденное ограничение двигательной активности при умственной деятельности?

2. Через какой промежуток времени после начала учебы в течение учебного дня у студентов проявляется оптимальная (устойчивая) умственная работоспособность?

3. Какова типичная динамика умственной работоспособности студентов в течение учебной недели?

4. Соответствует ли изменение физической работоспособности студентов в течение учебной недели динамике их умственной работоспособности?

5. В какие периоды в течение учебного года у студентов происходит максимальное снижение умственной и физической работоспособности? 
6. Оказывают ли влияние на работоспособность человека биологические ритмы?

7. Влияет ли уровень двигательной активности студентов в процессе обучения в вузе на состояние их здоровья?

8. Что понимается под двигательной активностью (ДА) человека?

9. На какие составные части можно условно разделить двигательную активность человека?

10. Что можно считать началом систематического физического воспитания студентов в России?

11. Можно ли эффективно решать проблемы оздоровления и повышения работоспособности студентов в период их обучения в вузе только в рамках учебных занятий по физическому воспитанию?

12. Какие «малые формы» занятий физическими упражнениями существуют в режиме учебного труда студентов?

13. Можно ли с помощью физических упражнений (занятий тем или иным видом спорта) формировать определенные психические качества и свойства личности?

Тема 6. Общая физическая подготовка и спортивная подготовка в системе физического воспитания

\section{План:}

6.1. Структура учебно-тренировочного занятия

6.2. Примерная программа ОФП

6.3. Спорт как уникальное социальное явление

6.4. Спорт в жизни студента

6.5. Индивидуальный выбор видов спорта или систем физических упражнений 
6.6. Особенности занятий избранным видом спорта или системой физических упражнений

\section{1. Структура учебно-тренировочного занятия}

Вводная часть занятия.

Учебно-тренировочное занятие строится с учетом реализации методических принципов физического воспитания. Общепринятым является четырехчасовое учебно-тренировочное занятие, состоящее из вводной, подготовительной, основной и заключительной частей.

Тренировочное занятие с квалифицированными спортсменами и самостоятельные занятия студентов строятся из трех частей, где две первые части объединяются в одну вводно- подготовительную часть, или разминку.

Можно рекомендовать следующее примерное распределение времени по частям занятий:

- при четырехчасовом занятии вводная часть - 5 мин, подготовительная (разминка) - 25 мин, основная - 53 мин, заключительная часть - 7 мин, всего - 90 мин.

· при трехчасовом занятии вводно-подготовительная часть (разминка) - 20-30 мин, основная - 50-60 мин, заключительная часть - 5-10 мин, всего90 мин.

Вводная часть занятия сводится к организации занимающихся (построение), созданию рабочей обстановки и психологического настроя на эффективное выполнение ими заданий преподавателя по обучению и совершенствованию техники физических упражнений, а также к выполнению запланированных на данное занятие объема и интенсивности тренировочных нагрузок. 
Во вводной части перед занимающимися ставятся конкретные задачи, создается четкое представление о содержании основной части, что позволяет более плодотворно решать задачи данного тренировочного занятия.

Подготовительная часть занятия.

Разминка обеспечивает преодоление периода вырабатывания. Она переводит организм занимающихся из состояния сравнительного покоя в деятельное состояние, в состояние готовности к выполнению повышенных физических нагрузок, способствует реализации принципа постепенности.

Физиологический механизм действия разминки следующий:

медленный бег в начале разминки приводит к раскрытию большого количества капилляров в сердечной мышце и скелетных мышцах. Активируются кровообращение и дыхание, температура внутренней среды организма повышается на $0,5-1,0^{\circ} \mathrm{C}$, что способствует увеличению проницаемости мембран легочных пузырьков, эритроцитов крови, мышечных волокон и клеток всех других тканей, повышает эффективность обмена веществ, улучшает питание тканей кислородом и питательными веществами, значительно увеличивает снабжение организма энергетическими веществами, а также повышает эффективность вывода из клеток продуктов распада, образующихся в процессе их активной деятельности;

гимнастические упражнения активизируют кровообращение в мышцах, мышечных сухожилиях, связках, окружающих суставы, в результате чего повышается их эластичность, что способствует увеличению работоспособности организма и профилактике травматизма.

Отсутствие разминки или небрежное еe проведение может отразиться на состоянии здоровья занимающихся (особенно сердечно-сосудистой системе) и привести к травмам.

Разминка делится на две части: общую и специальную. 
Общая разминка решает задачу активизации опорно-двигательного аппарата и деятельности внутренних систем организма, особенно сердечно-сосудистой и дыхательной. Для достижения этого применяются медленный бег (6-15 мин) и гимнастические упражнения на все группы мышц и все части тела (15-20 мин).

Специальная разминка направлена на повышение координационных способностей, создание энергетической основы, подготовку организма к выполнению последующих, более сложных по координации движений и более интенсивной тренировочной нагрузки.

В этой части разминки выполняются специальные подготовительные упражнения, сходные по координации движений и физической нагрузке с предстоящими двигательными действиями в основной части тренировочного занятия.

Специальная часть разминки на одном занятии может выполняться несколько раз, когда занимающиеся в основной части переходят к выполнению других физических упражнений.

Например, если в основной части занятия после тренировки в спринтерском беге занимающиеся переходят к занятиям метанием, то перед началом выполнения метаний необходима специальная разминка.

Основная часть разминки.

В основной части выполняются главные задачи, стоящие перед данным занятием, т.е. происходит обучение и совершенствование техники физических упражнений, и выполнение тренировочной нагрузки по воспитанию физических качеств.

Выполнение задач, связанных с разучиванием техники физических упражнений большей координационной сложности, осуществляется в самом начале основной части занятия.

Тренировочные нагрузки с целью воспитания физических качеств рекомендуется планировать в следующем порядке: сначала выполняются 
упражнения на быстроту движений, затем- на силу и в конце- занятия на выносливость (гибкость воспитывается в процессе разминки).

Иногда эта последовательность может меняться в целях развития у занимающихся способности проявлять высокую работоспособность при различных состояниях утомления организма.

Заключительная часть занятия.

Эта часть занятия направлена на обеспечение постепенного снижения функциональной активности и приведение организма в сравнительно спокойное состояние. Резкий переход от активных движений к покою включает действие мышечного насоса и перегружает сердечную мышцу. В этом случае после занятия занимающиеся могут испытывать дискомфортное состояние.

В заключительной части применяются медленный бег, ходьба, упражнения на расслабление с глубоким дыханием.

В конце заключительной части рекомендуется провести анализ проделанной тренировочной работы, связать ее с выполнением задач на данном этапе тренировки, определить содержание самостоятельных занятий и пр [29, 30, 31].

\section{2. Примерная программа ОФП}

Программа ОФП включает в себя основные группы упражнений. Руководствуясь ею, вы должны составить свою программу ОФП, включающую лишь те упражнения, которые необходимы для Вас. В этом вам помогут упражнения без снарядов, с партнером, с предметами и на снарядах.

Основная задача-увеличение мышечной массы. 
Сопутствующие задачи: а) повышение способности проявлять силу; б) повышение силовой выносливости; в) улучшение эластичности мышц и подвижности в суставах; г) исправление дефектов телосложения и осанки.

Средства:

1. Упражнения со штангой, гирями и другими отягощениями (жим, толчок, рывок, жим лежа, приседания, наклоны, повороты и т. п.). Выполняются до значительного мышечного утомления (до тех пор, пока не нарушится правильность движений) в 1-3 подхода с интервалом отдыха 2-5 мин. Интенсивность упражнения 50-70\% от максимальной. Эти упражнения включаются в основные занятия 3 раза в неделю.

2. Упражнения на преодоление веса тела (сгибания и разгибания рук в упоре лежа, подтягивания на высокой перекладине, приседание «пистолетом» и т.п.). То же на гимнастических снарядах (гимнастической стенке, скамейке, перекладине), ветвях дерева. Упражнения выполняются «до отказа» в 1-3 подхода с интервалом отдыха 1-3 мин. Применяются в утренней тренировочной зарядке 3-4 раза в неделю.

3. Прыжковые упражнения с продвижением (с ноги на ногу, на одной ноге, на двух ногах одновременно). Выполняются «до отказа». Повторяются 1-2 раза с интервалом отдыха 3-5 мин. Прыжковые упражнения включаются в основные занятия 2-3 раза в неделю.

Основная задача - развитие способности проявлять силу в различных движениях.

Сопутствующие задачи: a) воспитание воли к проявлению максимальных усилий; б) повышение способности концентрировать внимание и усилия; в) повышение быстроты движений.

Средства:

4. Упражнения со штангой (жим, толчок, рывок, «тяга», выжимание лежа, приседания с весом и т.п.). Выполняются однократно, в 2-3 подхода. 
Интервал отдыха 2-5 мин. Включаются в основные занятия 2 раза в неделю.

5. Те же упражнения со штангой, выполняемые 2-4 раза подряд, в 2-4 подхода с интервалами отдыха 2-5 мин. Интенсивность выполнения $75-80 \%$ от максимальной. Включаются в основные занятия 2 раза в неделю.

6. Изометрические (статические) упражнения (выжимание, подтягивание, скручивание и т.п.). Выполняются однократно, с максимальным напряжением в течение 6-8 с, в 2-4 подхода с интервалами 1-2 мин. Включаются в основные занятия 2 раза в неделю.

7. Прыжковые упражнения с предметной нацеленностью (дотянуться до подвешенного предмета, прыгнуть с места на гимнастический стол, перепрыгнуть через препятствие, преодолеть прыжками отрезок 30 м в кратчайшее время или с наименьшим количеством прыжков и т.д.). Интенсивность максимальная. Сделать в сумме 30-60 отталкивании. Включаются в основные занятия 2 раза в неделю.

8. Метание снарядов (набивной мяч, граната, ядро, камень и т. п.) в цель. Расстояние до нее постепенно увеличивается. Интенсивность максимальная. Выполнять на занятии 20-30 бросков 2 раза в неделю.

Основная задача — повышение общей быстроты движений.

Сопутствующие задачи: а) улучшение координации движений; б) повышение ловкости; в) повышение общей выносливости.

Средства:

1. Общеразвивающие подготовительные упражнения, каждое упражнение выполняется с возможно большей быстротой. Комплекс из 4-5 упражнений в 2-3 подхода сериями по 10 с. Включаются в 3-4 основные занятия.

2. Бег на 20-50 м с ходу и со старта, эстафетный и с гандикапом, эстафетный с преодолением препятствий. Выполняется повторно с 
интервалами 2-3 мин. В сумме пробегать 100-300 м в каждом из трех основных занятий в неделю.

3. Спортивные и подвижные игры (баскетбол, волейбол, хоккей, футбол на уменьшенном поле, борьба за мяч и т.п.). Играть по правилам. Время может быть укороченным. Проводятся как специальное занятие и в основном занятии вместо разминки или в конце тренировки, а также вечером.

Основная задача - развитие общей выносливости.

Сопутствующие задачи: а) воспитание воли к перенесению утомления; б) укрепление мускулатуры и суставно-связочного аппарата; в) выработка умения расслабляться.

Средства:

1. Бег в равномерном темпе при ЧСС 120 уд/ мин в основном занятии 2 раза в неделю с постепенным увеличением времени бега от 10-15 мин в первом занятии до 2-3 ч после двух месяцев тренировки. Бег можно заменять ходьбой на лыжах (3-4 часа), ездой на велосипеде (1-2 часа) или бегом на коньках (20-30 мин) непрерывно. В утренней ежедневной тренировке используется бег в равномерном темпе или фартлек продолжительностью 5-10 мин ежедневно.

2. Общеразвивающие подготовительные упражнения с предметами (гантели, скакалки, набивной мяч, палка и др.) и без них. Непрерывное выполнение комплекса упражнений поточным и круговым методом со средней интенсивностью в течение 5-15 мин в утренней тренировочной зарядке 5 раз в неделю. Включаются также в основные занятия 3 раза в неделю после разминки.

3. Свой вид спорта (лыжный, гребля, велосипедный и т. д.) или его варианты, или только бег, выполняемый по возможности непрерывно с малой и средней интенсивностью в течение 10-30 мин. Включаются в 
разминку в основных занятиях. Кроме того, могут выполняться в течение 45-60 мин постоянно на вечерней прогулке 3 раза в неделю.

4. Плавание 30-60 мин эпизодически в свободное время. Используется для активного отдыха..

Основная задача-развитие общей гибкости.

Сопутствующие задачи: а) повышение эластичности мышц; б) улучшение координации движений.

Средства:

5. Упражнения с большой амплитудой во всех суставах и во всех направлениях (наклоны, повороты, вращения, сгибания, размахивания и т. п.) на снарядах, с предметами и без них. Каждое упражнение выполняется в виде серии из 4-6 повторений с увеличивающейся амплитудой, 2-3 серии с интервалами отдыха 10-20 с. На все упражнения отводится 8-10 мин. Выполняется ежедневно в утренней тренировочной зарядке.

При плохой гибкости повторять упражнения вторично вечером.

Основная задача - улучшение координации движений и развитие ловкости. Сопутствующие задачи: а) развитие способности к проявлению «взрывной» силы; б) воспитание смелости и решительности; в) развитие гибкости; г) повышение эластичности мышц; д) укрепление мускулатуры.

Средства:

1. Акробатические упражнения (кувырки, перевороты, сальто и др.). Упражнения на подкидной доске и батуте. Выполнять повторно, затрачивая 15-25 мин на все упражнения вместе с интервалами отдыха, включать в основные занятия раз в неделю.

2. Упражнения на гимнастических снарядах (опорные прыжки, размахивания, перевороты, подъемы и т. д. на брусьях и перекладине). Выполнять повторно с интервалами отдыха 1-2 мин, затрачивая 15-30 мин на все упражнения. Включать в основные занятия 3 раза в неделю.

3. Горнолыжный спорт. Заниматься в свободное время 1-2 ч. 
4. Прыжки в воду - 8-12, а при овладении элементарной техникой больше. Заниматься в свободное время, соединяя тренировки с плаванием.

Старайтесь эффективнее использовать время занятий. В частности, в интервалах отдыха вы можете выполнять упражнения, требующие меньших усилий (например, сжимание теннисного мяча кистью) или иной направленности (например, отработка техники какого-либо движения или разучивание нового) [7].

\section{3. Спорт как уникальное социальное явление}

Спорт - игровая, соревновательная, творческая деятельность, направленная на раскрытие двигательных возможностей человека в условиях состязательного соперничества [16].

Спорт от физической культуры отличается тем, что в нем имеется обязательная соревновательная компонента. И физкультурник, и спортсмен могут использовать в своих занятиях и тренировках одни и те же физические упражнения (например, бег), но при этом спортсмен всегда сравнивает свои достижения в физическом совершенствовании с успехами других спортсменов в очных соревнованиях. Занятия же физкультурника направлены лишь на личное совершенствование безотносительно к достижениям в этой области других занимающихся. Вот почему мы не можем назвать спортсменом бодрого старичка, передвигающегося по аллеям сквера «джогингом» - смесью быстрой ходьбы и медленного бега. Этот уважаемый человек не спортсмен, он физкультурник использующий ходьбу и бег для поддержания своего здоровья и работоспособности.

Однако все эти рассуждения и примеры хотя и помогают договориться о едином толковании отдельных понятий, но не раскрывают всю многогранность такого общественного явления, каким является современный спорт. Он выступает во многих ипостасях: как средство 
оздоровления, и как средство психофизического совершенствования, и как действенное средство отдыха и восстановления работоспособности, и как зрелище, и как профессиональный труд.

Итак, спорт как соревновательная, а также тренировочная деятельность, направленная на достижение максимально возможного результата, — это и органическая часть физической культуры, и один из каналов передачи ее ценностей, и действенный фактор системы физического воспитания, и одна из основных форм подготовки человека к жизни, и одно из важных средств этического и эстетического воспитания, и специфические отношения, нормы и достижения, и особая сфера выявления, развития и сравнения человеческих возможностей (психофизических способностей и умения рационально пользоваться ими).

Наряду с направленностью к высшим достижениям существенными особенностями спорта являются:

1) постоянное присутствие сложного комплекса межчеловеческих отношений сотрудничества, соперничества, борьбы, целого мира эмоций;

2) максимальные требования не только к физическим, по и к духовным качествам спортсмена;

3) творческий, поисковый характер деятельности спортсмена в содружестве с тренером;

4) универсальность «языка спорта», понятного практически любому человеку;

5) зрелищность многих видов спорта;

6) система прогрессирующего поощрения (разряды, звания, награды, чествования и т. п.) [14].

Изучение спорта с разных сторон (в разных аспектах) позволило ученым установить огромное число его функций (более 110). Вот насколько спорт многогранен! Например, у спорта выявлены в преобразовательном аспекте подготовительная, воспитательная, 
оздоровительная и образовательная функции, в коммуникативном (связующем) аспекте функции общения, обмена опытом, международного сотрудничества, в психологическом аспекте функции отвлечения, волевой и моральной подготовки, интеллектуализации, снятия напряжения после трудовой деятельности.

Многогранность спорта как социального явления сопровождается многообразием видов двигательной деятельности в нем. Различают множество видов спорта. Каждый из них характеризуется своим предметом состязания, особым составом действий и способов ведения спортивной борьбы (техникой и тактикой), своими правилами. Так, например, в нашей и стране культивируется около 150 видов спорта.

Виды спорта, получившие международное распространение по особенностям предмета состязания и характеру двигательной активности спортсмена можно подразделить на следующие пять групп (Г.С. Решетников, 1977):

1) виды спорта, для которых характерна активная двигательная деятельность спортсмена; основой успеха в них является степень развития его собственных двигательных возможностей (например, легкая атлетика, плавание, борьба и многие другие);

2) виды спорта, где успех зависит от степени мастерства в управлении техническим средством или животным (например, авто- и мотоспорт, парусный, конный спорт и т. п.);

3) виды спорта, где успех зависит от точных действий, связанных с поражением целей (например, стрельба из пистолета, лука и т. п.);

4) виды спорта, где основой успеха служит модельно-конструкторская деятельность спортсмена (например, авиа- , автомодельный спорт и т. п.); 
5) виды спорта с ограниченной подвижностью, где основа успеха теоретическая подготовленность спортсмена (например, шахматы, шашки и т. п.) [27].

Отметим, что у видов спорта абсолютно разный исторический возраст и разное происхождение. Истоком таких «древних» видов спорта как, например, легкая атлетика, борьба, являются трудовые и боевые действия. Кстати, трудовая практика и военное дело влияют и на формирование некоторых современных видов спорта профессионально прикладной направленности (например, пожарно-прикладной, радиоспорт, автоспорт и т. п.). В последнее столетие формирование новых видов спорта происходит на базе самого спорта и двух других форм культуры материальной и духовной. Так возникли, например, в свое время баскетбол, велобол, воднолыжный спорт, серфинг, прыжки на батуте, спортивные танцы на льду, художественная гимнастика, фристайл и многие другие. Особо подчеркнем, что независимо от своего исторического возраста и происхождения любой вид спорта может быть использован в качестве действенного фактора направленного развития тех или иных психофизических способностей человека.

Из рассмотренного можно сделать следующий вывод: спорт - это социальный феномен культуры, имеющий колоссальное воспитательное значение для человека.

Выполнение спортом различных социальных функций определяет существование различных сфер спортивного движения. Это, прежде всего такие сферы, как массовый (базовый) спорт и спорт высших достижений (большой спорт), любительский и профессиональный спорт.

Массовый спорт дает возможность миллионам людей совершенствовать свои физические качества и двигательные возможности, укреплять здоровье и продлевать творческое долголетие, а значит, 
противостоять нежелательным воздействиям на организм современного производства и условий повседневной жизни.

Цель занятий различными видами массового спорта - укрепить здоровье, улучшить физическое развитие, подготовленность и активно отдохнуть. Это связано с решением ряда частных задач, повысить функциональные возможности отдельных систем организма, скорректировать физическое развитие и телосложение, повысить общую и профессиональную работоспособность, овладеть жизненно необходимыми умениями и навыками, приятно и полезно провести досуг, достичь физического совершенства.

Задачи массового спорта во многом повторяют задачи физической культуры, но реализуются спортивной направленностью регулярных занятий и тренировок.

К элементам массового спорта значительная часть молодежи приобщается еще в школьные годы, а в некоторых видах спорта даже в дошкольном возрасте. Именно массовый спорт имеет наибольшее распространение в студенческих коллективах. [14]

Как показала практика, обычно в нефизкультурных вузах страны в сфере массового спорта регулярными тренировками во внеурочное время занимаются от 10 до 25\% студентов. Ныне действующая программа по учебной дисциплине «Физическая культура» для студентов высших учебных заведений позволяет практически каждому здоровому студенту и студентке любого вуза приобщиться к массовому спорту. Это можно сделать не только в свободное время, но и в учебное. Причем, вид спорта или систему физических упражнений выбирает сам студент.

Наряду с массовым спортом существует спорт высших достижений, или большой спорт. 
Цель большого спорта принципиально отличается от цели массового. Это достижение максимально возможных спортивных результатов или побед на крупнейших спортивных соревнованиях.

Всякое высшее достижение спортсмена имеет не только личное значение, но становится общенациональным достоянием, так как рекорды и победы на крупнейших международных соревнованиях вносят свой вклад в укрепление авторитета страны на мировой арене. Поэтому нет ничего удивительного в том, что крупнейшие спортивные форумы собирают у экранов телевизоров всего мира миллиардные аудитории, а среди прочих духовных ценностей столь высоко ценятся и мировые рекорды, и победы на чемпионатах мира и лидерство на Олимпийских играх.

Нельзя не сказать еще об одной общественной ценности большого спорта, которая обычно остается в тени. Сегодня спорт высших достижений - пока единственная модель деятельности, при которой у выдающихся рекордсменов функционирование почти всех систем организма может проявляться в зоне абсолютных физиологических и психических пределов здорового человека. Это позволяет не только проникнуть в тайны максимальных человеческих возможностей, но и определить пути рационального развития и использования имеющихся у каждого человека природных способностей в его профессиональной и общественной деятельности, повышения общей работоспособности.

Для выполнения поставленной цепи в большом спорте разрабатываются поэтапные планы многолетней подготовки и соответствующие задачи. На каждом этапе подготовки эти задачи определяют необходимый уровень достижения функциональных возможностей спортсменов, освоение ими техники и тактики в избранном виде спорта. Все это суммарно должно реализоваться в конкретном спортивном результате [27]. 
Любительский спорт - это сфера, в которой человек занимается спортивной деятельностью параллельно с другими видами своей деятельности (учебой, работой, службой в армии и т. д.), т. е. спорт в этом случае не профессия.

Профессиональный спорт - это сфера в которой двигательная спортивная деятельность, для человека является основным родом занятий, т. е. его профессией. В основе этой сферы лежит коммерческая деятельность, предусматривающая экономическую эффективность и высокую информационно-развлекательную ценность спортивно-зрелищных мероприятий. Профессиональный спорт существует в двух формах - спорта высших достижений и спорта показательного (например, соревнования по баскетболу в профессиональной лиге НБА и баскетбольный профессиональный цирк).

Кто же может считаться спортсменом? Спортсмен (от английского sportsmen - человек спорта; честный, порядочный человек) - это человек, который систематически занимается избранным видом спорта и регулярно принимает участие в спортивных соревнованиях. Спортсмен высокого класса - это спортсмен, выступающий на крупнейших национальных и международных соревнованиях и имеющий спортивное звание не ниже звания мастера спорта.

Спортивные звания и разряды регламентируются разработанной и периодически (каждые четыре года) пересматриваемой Единой всероссийской спортивной классификацией. Она представляет собой сборник нормативов и требований более чем по 110 видам спорта, выполнение которых спортсменом позволяет присвоить ему соответствующий спортивный разряд или звание.

Практикуется система присвоения разрядов от третьего юношеского до первого взрослого и званий кандидата в мастера спорта (КМС), мастера 
спорта (MC), мастера спорта международного класса (МСМК), гроссмейстера (в шахматах, шашках), заслуженного мастера спорта (ЗМС).

Показатели разрядных нормативов в классификации выражены в количественных мерах (например: кг, м, с, очки, баллы и т. п.). Показателями разрядных требований в ней являются определенные места, которые должен занять спортсмен или команда, определенное количество побед, одержанных спортсменом или командой над своими соперниками, масштаб соревнований. В одних видах спорта (например, в легкой атлетике, плавании и т.п.) применяются нормативы, и требования; в других же (например, игровые виды спорта, бокс, фехтование и т. п.) - только разрядные требования.

Единая всероссийская спортивная классификация стимулирует развитие спорта в стране через интерес занимающихся к повышению своей спортивной квалификации. Она также дает возможность количественной и качественной оценки состояния спорта в целом и отдельных его видов в масштабах страны, региона, города и т. д [31].

\section{4. Спорт в жизни студента}

Возрастные особенности студенческой молодежи, специфика учебного труда и быта студентов, особенности их возможностей и условий занятий физической культурой и спортом позволяют выделить в особую категорию студенческий спорт.

Организационные особенности студенческого спорта.

1) доступность и возможность заниматься спортом в часы обязательных учебных занятий по дисциплине «Физическая культура» (элективный курс в основном учебном отделении, учебно-тренировочные занятия в спортивном учебном отделении); 
2) возможность заниматься спортом в свободное от учебных академических занятий время, в вузовских спортивных секциях и группах, а также самостоятельно;

3) возможность систематически участвовать в студенческих спортивных соревнованиях доступного уровня (в учебных зачетных соревнованиях, во внутри- и вневузовских соревнованиях по избранным видам спорта).

Вся эта система дает возможность каждому практически здоровому студенту сначала познакомиться, а затем выбрать вид спорта для регулярных занятий.

Как правило, в вузе, обучающем 3500-5000 студентов практикуется 25-30 видов спорта и занятий различными системами физических упражнений.

В зависимости от климатических условий, месторасположения вуза, возможностей его материально-технической базы, особенностей будущей профессиональной деятельности выпускников, а также контингента тренерско-преподавательского состава меняются количество, содержание форм и видов спортивного совершенствования [14].

Понятно, что перечисленными выше причинами не исчерпываются пути развития, становления того или иного вида спорта: национальные традиции, новаторская инициатива спортивной общественности, наконец, мотивация студенческой молодежи могут быть не менее решающими.

Наиболее популярны и доступны сегодня занятия следующими видами спорта и системами физических упражнений: бег на длинные дистанции, кросс, ходьба и бег на лыжах, велоспорт, плавание, спортивные игры, особенно баскетбол, волейбол и их «производные» (пляжный волейбол, игры «3» на «3», «2» на «2» и др.), настольный теннис, футбол, мини футбол, тренажерная гимнастика, спортивная аэробика, атлетическая гимнастика, восточные виды единоборств и стилей рукопашного боя и 
самозащиты, туризм, скалолазание, спортивное ориентирование, альпинизм, а также горнолыжный спорт и его разновидности, конькобежный спорт. Начинают входить в моду и культивироваться оздоровительные системы, сочетающие физические упражнения и средства закаливания, общей и локальной коррекции тела, мышечной массы, упражнения реабилитационного характера для ликвидации последствий нервных срывов, стрессовых состояний. Как всегда, студенческая молодежь с интересом откликается на экзотические нововведения, нетрадиционные виды спорта и отдыха.

Нетрадиционные виды физических упражнений и спорта: акватлон, акробатический рок-н-ролл, армрестлинг, бейсбол, болдринг, гидроаэробика, дайдинг, каратэ, йога, пауэрлифтинг, ушу, перетягивание каната, сквош, сумо, триатлон, фитнес-аэробика, фристайл, шейпинг, шорт-трек и другие.

Студенческий спорт курируют Министерство образования и науки РФ совместно с Федеральным агентством по физической культуре, спорту и туризму. Непосредственное руководство отечественным студенческим спортивным движением осуществляется единым органом. Ранее это был Центральный совет добровольного спортивного общества «Буревестник» (это общество было организовано в 1957 г.). правопреемником стал Исполнительный комитет Российского студенческого спортивного союза (РССС). Этот союз объединяет физкультурные организации более 500 высших и 2500 средних специальных учебных заведений России, в которых культивируется около 50 видов спорта с проведением по ним регулярных соревнований.

РССС тесно сотрудничает с Международной федерацией студенческого спорта (ФИСУ), призванной руководить международным студенческим движением. ФИСУ была основана в 1949 г. Наша страна вступила в эту организацию в 1959 г. (В.Д. Чепик, 1995). 
Существует достаточно отлаженная и вместе с тем постоянно развивающаяся система школьных и студенческих спортивных соревнований. Внутри каждого учебного заведения проводятся спартакиадные соревнования по обязательным и по популярным видам спорта, другие спортивные состязания (например, под девизом «А ну-ка, парни!» и т.п.). Победители внутренних соревнований принимают участие в составе сборных команд учебного заведения в спартакиадах, первенствах по отдельным видам спорта более высокого масштаба (района, города, области, отрасли и т. п.), губернаторских соревнованиях. В спортивном школьном календаре появились, благодаря инициативе нашего государства, Всемирные юношеские игры. У студентов начиная с 1996 г. ежегодно стали проводиться фестивали спорта. Сильнейшие студенты-спортсмены принимают участие в составе сборной команды России в универсиадах (Всемирных студенческих играх), проводимых под эгидой ФИСУ (в нечетные годы проводятся летние, в четные годы - зимние игры) [30].

Организованно студенты занимаются спортом в спортивных секциях своего учебного заведения, в спортивных школах разных типов, в специализированных спортивных клубах, спортивно-оздоровительных лагерях; самодеятельным образом - при стадионах, спортивных комплексах по месту жительства, в местах проведения своего каникулярного времени.

\section{5. Индивидуальный выбор видов спорта или систем физических упражнений}

Спорт может сыграть очень важную роль для каждого молодого человека и девушки. Ведь он, являясь как бы моделью жизни, способен эффективно подготовить вас ко всем видам деятельности, и, конечно, в первую очередь к трудовой. В нем вы проявляете и реализовываете себя, 
свои способности и интересы, развиваете тело и многие личностные черты (например, характер, способности и т. д.). Здесь вы трудитесь, состязаетесь, взаимодействуете, общаетесь с другими людьми; побеждаете и проигрываете; страдаете и наслаждаетесь. «Спорт не дает человеку погрязнуть в скуке, безделье, отвлекает от пьянки, хулиганства... Физкультура укрепляет тело. Спорт почти всегда закаляет дух. Спорт есть вещь духовная... Решающее значение для всего общества имеют массовые самостоятельные занятия спортом... И не опасайтесь нагружать себя, уставать», — говорит известный математик академик А. Д. Александров.

Между тем недавняя статистика утверждала, что большим спортом занимались 0,4-0,8\%, а массовым- 15-20\% от общего числа студентов в стране. В настоящее время из-за целого ряда социально-экономических причин эти показатели, вероятнее всего, еще ниже.

И все же, несмотря на трудности объективного характера, вам следовало бы найти возможность для занятий спортом в целях собственного жизненного благополучия. Для начала надо решить проблему выбора вида спорта.

Как показала практика, учащихся побуждают заниматься спортом четыре мотива:

1) с целью достижения высоких спортивных результатов;

2) с целью укрепления здоровья, коррекции телосложения, повышения психологической устойчивости;

3) с целью активного отдыха;

4) с целью психофизической подготовки к будущей профессиональной деятельности [14].

Для занятия спортом с целью оздоровительной или активного отдыха, как считают ученые-психологи и педагоги, следует ориентироваться не только на интерес к тому или иному виду спорта, но и на черты своего характера. Так, если человек легко отвлекается от работы и снова быстро в 
нее включается, общителен, эмоционален, то ему лучше всего остановить свой выбор на игровых видах спорта или единоборствах; если же усидчив, склонен к однородной деятельности без постоянного переключения внимания, способен длительное время выполнять тяжелую физическую работу, то ему подойдут занятия бегом, лыжным спортом, плаванием; а если замкнут, необщителен, неуверен в себе или чрезмерно чувствителен к мнению окружающих, то ему не стоит заниматься в организованных группах. Индивидуальные же занятия различными системами физических упражнений без отвлекающих факторов помогут испытать положительные эмоции, принесут физическое и моральное удовлетворение.

Выбор вами спортивного увлечения может быть сделан из следующих видов спорта, классифицируемых по признаку преимущественного развития того или иного физического качества.

К видам спорта, в первую очередь развивающих выносливость, относятся легкая атлетика (спортивная ходьба, бег на средние и длинные дистанции), лыжные гонки, биатлон, плавание, гребля, шоссейные гонки и кросс на велосипеде, бег на коньках, альпинизм, спортивное ориентирование и некоторые другие.

Видами спорта, преимущественно развивающими силу и скоростно-силовые качества являются, например, тяжелая атлетика, гиревой спорт, атлетическая гимнастика, легкая атлетика (спринт, прыжки, метание) и т. п.

Для развития быстроты следует использовать, например, легкую атлетику (спринтерский гладкий и барьерный бег, метание копья), конькобежный спорт (спринт), велоспорт (спринт на треке), фехтование, бокс и другие единоборства, бейсбол, русскую лапту.

Совершенствованию ловкости и гибкости способствуют акробатика, спортивная и художественная гимнастика, прыжки в воду, на батуте, на 
лыжах с трамплина, фристайл, горнолыжный спорт (слалом), фигурное катание, спортивные игры, единоборства.

Разностороннему комплексному развитию качеств способствуют виды спорта, связанные с традиционными отечественными и восточными единоборствами (борьба вольная и классическая, самбо, дзюдо, джиу-джитсу, карате, таэквондо, ушу, бокс, тайбокс, кикбоксинг), фехтование; спортивные игры, виды спорта, в которых есть многоборье (например, легкоатлетические десятиборье и семиборье, лыжное двоеборье, современное пятиборье и т. п.) [24].

Выбор своей двигательной деятельности может быть вами сделан и из числа различных современных систем физических упражнений, развивающей, рекреативной (восстановительной) и корригирующей (исправляющей) направленности. Таких, например, как бодибилдинг, или атлетическая гимнастика, аэробика, или ритмическая гимнастика с основами хатха-йоги, шейпинг (сочетание ритмической и атлетической гимнастики), стретчинг (упражнения на растягивание мышц и повышение подвижности суставов), систем Купера (контролируемые физические нагрузки в циклических упражнениях), Амосова (гимнастика для суставов), Лидьярда (бег ради жизни), Моргауза (всего 30 минут спорта в неделю на фоне повседневной естественной физической нагрузки), скрытая изометрическая гимнастика но Томпсону (произвольное поочередное сокращение мышц тела без изменения их длины), системы дыхательных упражнений А. Н. Стрельниковой, К. П. Бутейко [27].

Влияние избранного вида спорта или системы физических упражнений на физическое развитие, функциональную подготовленность и психические качества

Продолжительные и регулярные занятия спортом или физическими упражнениями влияют на физическое развитие, функциональную подготовленность и состояние психики человека. Этот факт может быть 
использован для коррекции показателей физического развития и телосложения, для акцентированного воспитания и совершенствования силы, быстроты, выносливости, гибкости, а также психических качеств личности. Проблема акцентированного развития физических качеств всегда легче решается на начальных этапах спортивной подготовки. Если вы развиваете какое-то физическое свойство, то тем самым параллельно развиваются и другие. Однако по мере повышения тренированности, с ростом спортивной квалификации (от новичка до спортсмена-мастера) величина эффекта параллельного развития нескольких физических качеств постепенно уменьшается. Чем выше класс спортсмена, тем контрастнее проявляются те физические качества, к которым предъявляет особые требования конкретный вид спорта. Иными словами, налицо акцентированное воздействие данного вида спорта на развитие определенного физического качества.

Аналогичные процессы можно наблюдать и в развитии и воспитании психических качеств и свойств личности. Виды спорта, требующие повышенной смелости, волевых усилий, коллективизма, всегда оставляют отпечаток на личности спортсмена. Системы же физических упражнений, как правило, направлены на развитие какого-либо определенного физического или психического качества (например, «стретчинг» или системы дыхательной гимнастики).

Каждый студент может выбрать вид спорта в элективном курсе учебной дисциплины «Физическая культура» из числа предлагаемых кафедрой физического воспитания в данном вузе. Чтобы не ошибиться в своем выборе, он должен иметь хотя бы общие представления о характере воздействия того или иного вида спорта (системы физических упражнений) на человека.

В этом ему может помочь предлагаемое разделение основных видов спорта на группы: 
1) преимущественно развивающие выносливость (циклические виды спорта);

2) развивающие, главным образом, силу и скоростно-силовые качества (тяжелая атлетика, легкоатлетические метания и прыжки);

3) способствующие воспитанию ловкости и гибкости (спортивная гимнастика, акробатика);

4) комплексного воздействия на человека (разные виды единоборств, спортивные игры, различные многоборья).

В этом разделении на группы, хотя и несколько условно, могут найти свое место и избранный вид спорта, или современная система физических упражнений.

Особенности совершенствования в каждом виде спорта или системе физических упражнений требуют более подробного освещения в лекционном курсе. Лектор должен дать специфические материалы, сведения, примеры по конкретному виду спорта или системе физических упражнений или адресовать студентов к доступной специальной литературе.

\section{6. Особенности занятий избранным видом спорта или системой физических упражнений}

Планирование спортивной подготовки студента.

Перспективное планирование спортивной подготовки студента заключается в том. чтобы обеспечить непрерывность тренировочного процесса, так как оно связывает в единую многолетнюю систему подготовку на учебных снятиях по дисциплине «Физическая культура» в средней школе и вузе, а также занятия в свободное время на всем протяжении обучения (включая учебные и производственные практики, а также каникулярное время) В некоторых случаях перспективный план 
спортивной подготовки должен охватывать и послевузовский период подготовки спортсмена.

Между тем спортивная подготовка в основном учебном отделении вуза планируется только на годы учебных занятий по дисциплине «Физическая культура». Перспективное планирование в данном случае состоит в постепенном усложнении задач по освоению обязательного программного и элективного учебного материала. В конечном счете, это находит свое отражение в усложняющихся зачетных спортивно-технических нормативах и требованиях.

Перспективное планирование в спортивном учебном отделении имеет свои особенности. С одной стороны оно предусматривает постепенное усложнение учебно-тренировочного процесса по годам обучения, с другой - может охватывать не только период обучения в вузе, но и спортивную подготовку спортсмена после окончания учебного заведения. Такое планирование, захватывающее послевузовский период спортивной подготовки, наиболее четко проявляется в индивидуальных видах спорта [14].

Перечень и уровень зачетных спортивно-технических нормативов и требований к студентам по годам обучения разрабатываются кафедрой физического воспитания с учетом общей физической и спортивной подготовленности учебных групп по каждому из видов спорта. Иногда студентам ставятся задачи достичь или подтвердить определенные спортивные разряды по годам обучения в вузе.

В каждом вузе наряду с обязательными зачетными требованиями по общей физической и профессионально-прикладной физической подготовке студентам должны быть заблаговременно объявлены спортивно-технические нормативы и требования по годам обучения, а не только на предстоящий семестр. Это позволит им представлять степень 
трудности освоения учебно-тренировочного материала не только на предстоящий семестр, но и на перспективу.

Годичное планирование.

При годичном планировании тренировок применяются два варианта планирования: обычный и со сложной структурой соревновательного периода - проведением нескольких последовательных соревнований.

На выбор вариантов годичного планирования тренировок влияют вид спорта, квалификация спортсменов, этап многолетней тренировки и другие факторы. Например, в сезонных видах спорта (лыжи, гребля) в основном применяется однопиковый годичный цикл с тремя периодами подготовки, в отдельных дисциплинах легкой атлетики (по которым проводятся и зимние и летние соревнования) двухпиковый и т.д.

Перед студенческим спортом всегда стояли определенные сложности при планировании тренировки. Особенности периодов наивысшей учебной нагрузки, разновременные и разнохарактерные учебные и производственные практики в разных вузах, факультетах и на разных курсах создают дополнительные сложности, как для составления спортивного календаря, так и для планирования тренировочного процесса студентов-спортсменов. Эти сложности усугубляются при планировании подготовки сборных студенческих команд по спортивным играм любого уровня (факультета, вуза), где играют студенты разных курсов и факультетов. Планирование тренировки в таких случаях требует включить значительный объем самостоятельной подготовки по отдельным разделам тренировочного процесса.

C особыми трудностями планирования тренировки студента-спортсмена сталкиваются преподаватели-тренеры (да и сами спортсмены) в тех случаях, когда он выходит в большой спорт, где календарь спортивных соревнований совершенно не учитывает особенности учебного процесса в вузе. В этом случае неизбежно 
нестандартное решение проблемы с возможным предоставлением индивидуального графика обучения для сильнейших спортсменов, а при подготовке к крупнейшим международным спортивным соревнованиям (Универсиада, Олимпийские игры) даже предоставление академического отпуска.

Текущее и оперативное планирование.

Текущее планирование связано с учебно-тренировочного процесса, подготовкой к отдельным соревнованиям или их серии. Оно призвано представить различные факторы тренировочного процесса (подбор соответствующих средств тренировки, соревновательных стартов, методов направленного восстановления и стимуляции работоспособности), в таком сочетании, которое обеспечивало бы условия для подготовки спортсмена к проявлению наивысших возможностей на основных соревнованиях.

С одной стороны, планируются определенные «блоки» из серии тренировочных занятий с конкретными задачами подготовки, с другой проводится постоянный текущий контроль за специфической работоспособностью спортсмена путем различных тестов, ибо важно выявить эффективность подготовки после каждого «блока» тренировочных занятий.

Текущее планирование в основном и спортивном отделениях существенно различаются, особенно в видах и формах текущего контроля. В основном отделении чаще применяются тесты, а в спортивном - coревновательные упражнения (на вспомогательных дистанциях и их отрезках, в нестандартных упражнениях, не используемых в официальных соревнованиях).

Оперативное планирование, или управление учебно-тренировочным процессом, - определяет степень физической, технической, тактической подготовленности студента-спортсмена. Оцениваются самые различные 
показатели, отражающие возможности организма, реакции на отдельные виды физических упражнений, продолжительность пауз между ними.

Современные технические средства позволяют оперативно получать и доводить до занимающихся информацию о динамических и кинематических характеристиках движений, реакции основных функциональных систем, их соответствии заданным характеристикам. Это позволяет своевременно корректировать индивидуальные нагрузки, использование тренировочных средств.

Оперативное планирование предусматривает контроль всех сторон спортивной подготовки. Оно не имеет существенных отличий при подготовке студентов в основном и спортивном отделениях, но в каждом виде спорта оперативное и текущее планирование имеют свои отличия. Об этом речь должна идти на лекции по данной теме [27].

Пути достижения физической, технической, тактической и психической подготовленности.

Представив общую структуру подготовленности спортсменов или занимающихся одной из систем физических упражнений (СФУ) в виде отдельных элементов, можно систематизировать средства и методы их совершенствования. Все стороны спортивной подготовленности тесно взаимосвязаны. Так, техническое совершенствование напрямую зависит от уровня развития физических качеств - силы, быстроты, гибкости, ловкости, а выносливость тесно связана с экономичностью техники спортивного движения, уровнем психической устойчивости при преодолении утомления. Тактическая подготовленность опирается на функциональную подготовленность и уровень технического мастерства, на психические качества спортсмена (смелость, решительность).

Физическая подготовленность в избранном виде спорта.

Физическая подготовленность характеризуется возможностями функциональных систем организма спортсмена. Условно ее можно 
подразделить на общую и специальную. Связующее звено между ними вспомогательная подготовленность.

Общая физическая подготовленность предполагает разностороннее развитие физических качеств, слаженность их проявления в процессе мышечной деятельности.

Общая физическая подготовка особенно акцентируется на I- II курсах. Контроль за ней осуществляется на всех курсах, во всех учебных отделениях (основном, специальном, спортивном) в течение всех лет обучения в вузе. Именно этой цели служат и «сквозные» тесты по ОФП (бег 100, 2000 м - женщины, 3000 м - мужчины, и специальные силовые упражнения для женщин и мужчин).

Однако по ряду видов спорта общий уровень программных требований ОФП в отдельных упражнениях может быть недостаточным для студентов, специализирующихся в каком-либо виде спорта или системе физических упражнений [30].

Вспомогательная физическая подготовленность, с одной стороны, восполняет необходимые повышенные требования к развитию определенных физических качеств в данном виде спорта или системе физических упражнений, а с другой - служит функциональной основой для успешной работы над развитием специальных физических качеств и способностей.

Так, для спортивной специализации в лыжных гонках недостаточны общие требования в беге на 3 км ни по заданному времени (на оценку 5 очков), ни по длине дистанции. В этом случае в предсезонный период подготовки может быть введен (в учебной группе «лыжников») дополнительный тест, например в беге на 5-10 км с соответствующими требованиями к скорости преодоления этих дистанций. Такая вспомогательная физическая подготовка поможет более плавно перейти к 
специализированной подготовке и к определенным соревновательным дистанциям в лыжных гонках $(15,30,50$ км).

Специальная физическая подготовленность характеризует уровень развития именно тех физических качеств, возможностей органов и функциональных систем организма, с которыми непосредственно связаны достижения в избранном виде спорта. Специальная подготовленность присуща только данному виду спорта или системе физических упражнений. Она может быть выражена в спортивно-технических требованиях к скоростным, силовым способностям, гибкости, координационным возможностям, специальной выносливости. Соответствующую направленность имеют и спортивно-технические нормативы и требования, предлагаемые студентам по семестрам и годам обучения.

Техническая подготовленность в избранном виде спорта или СФУ.

На содержание технической подготовки в каждом виде спорта влияют любые изменения в правилах соревнований, конструкции и качестве спортивного инвентаря и т.д. В структуре технической подготовленности выделяются базовые и дополнительные движения.

К базовым относятся движения и действия, составляющие основы технической оснащенности данного вида спорта, без которых невозможно осуществлять соревновательную борьбу по правилам. Освоить базовые движения - обязательное условие для спортсмена, специализирующегося в том или ином виде спорта. В основном учебном отделении именно на эту группу движений делается акцент в процессе начальной спортивной подготовки. Такие же базовые движения существуют и в различных системах физических упражнений.

Дополнительные движения и действия - это второстепенные элементы движений, характерные для отдельных спортсменов и связанные с их индивидуальными особенностями. Именно эти движения и действия формируют индивидуальный стиль, техническую манеру спортсмена, 
позволяющие добиваться преимуществ в противостоянии с равными соперниками. Этот индивидуальный стиль всячески поддерживается тренером-преподавателем.

Техническая подготовленность спортсмена во многом определяется той целью, на достижение которой направлено соответствующее двигательное действие. В скоростно-силовых, циклических, сложно-координационных видах спорта, в спортивных играх и единоборствах такие цели различаются.

Для одних видов спорта большее значение имеет стабильность техники, для других — еe вариативность, для третьих — экономичность техники, для четвертых — минимальная тактическая информативность об этих индивидуальных технических приемах для соперников. Но в любом случае главными последовательными задачами процесса совершенствования технического мастерства спортсмена будут следующие.

1. Достичь высокой стабильности и вариативности специализированных движений-приемов, составляющих основу техники данного вида спорта.

2. Последовательно превращать освоенные основы техники в целесообразные и эффективные соревновательные действия.

3. Усовершенствовать структуру двигательных действий с учетом индивидуальных особенностей спортсмена.

4. Повысить надежность и результативность техники действий спортсмена в экстремальных соревновательных ситуациях.

5. Совершенствовать техническое мастерство спортсменов исходя из требований спортивной практики и достижений научно-технического прогресса в сфере спортивного инвентаря и оборудования.

Тактическая подготовленность в избранном виде спорта или СФУ. 
Активность тактических действий спортсмена важный показатель спортивного мастерства. Спортсмен высокой квалификации должен уметь навязывать сопернику свою волю, оказывать на него постоянное психологическое давление разнообразными и эффективными действиями. Это требование распространяется на командные и индивидуальные виды спорта, на контактные и неконтактные единоборства.

Тактическая подготовка спортсмена всегда опирается на его физическую и техническую подготовленность. При этом учитываются его индивидуальные особенности, в том числе и психологического характера.

Структура тактической подготовленности определяется характером стратегических задач, диктующих основные направления спортивной борьбы. Эти задачи могут быть связаны с участием спортсмена или команды в серии соревнований, чтобы подготовиться и успешно выступать в главных соревнованиях сезона или цикла (например, студенческая Универсиада, Олимпийские игры). Но тактические задачи могут быть и более локальными, связанными с участием в отдельных соревнованиях или даже в конкретном поединке, схватке, забеге, игре. В последнем случае приходится учитывать такие особенности конкретных соревнований, как характер судейства, поведение болельщиков, состояние мест соревнований. При разработке тактического плана нужно иметь в виду собственные функциональные и технико-тактические возможности, а также возможности своих партнеров. [24]

Психологическая подготовленность спортсмена. Под психологической подготовкой следует понимать совокупность психолого-педагогических мероприятий и соответствующих условий спортивной деятельности и жизни спортсменов, направленных на формирование у них таких психических функций, процессов, состояний и свойств личности, которые обеспечивают успешное решение задач тренировки и участия в соревнованиях. 
Психологическую подготовку принято делить на общую и специальную. Суть общей психологической подготовки заключается в том, что она направлена на развитие и совершенствование у спортсменов именно тех психических функций и качеств, которые необходимы для успешных занятий в избранном виде спорта, для достижения каждым спортсменом высшего спортивного мастерства.

Специальная психическая подготовка направлена главным образом на формирование у спортсмена психологической готовности к участию в конкретном соревновании.

Специфика вида спорта предъявляет различные требования к качествам и структуре психологической подготовленности спортсмена. Так спортсменам, специализирующимся в боксе, борьбе, тяжелой атлетике, метаниях, спринтерских дистанциях видов спорта циклического характера, присущи такие качества, как склонность к лидерству, независимость, высокий уровень мотивации, склонность к риску, умение сконцентрировать в нужный момент все свои силы и отдать их для победы. Но одновременно им часто свойственны недоверчивость, стремление избежать подчиненной роли, упрямство, склонность к конфликтам.

Для спортсменов, специализирующихся на длинных дистанциях, характерны активность, способность к перенесению высоких нагрузок, умение подчинять личные интересы общественным, отсутствие мнительности. Однако они нередко недостаточно уверены в собственных силах, нуждаются в лидере, склонны к своеобразным поступкам и суждениям.

Спортсменов, специализирующихся в спортивных играх и единоборствах, сложнокоординационных видах спорта, отличают эффективное зрительное восприятие, быстрота сенсомоторного реагирования и оперативного мышления, широкое распределение, быстрое переключение и устойчивость внимания, сообразительность, 
настойчивость, решительность, смелость, быстрота и точность сложных двигательных реакций, легкость образования и перестройки двигательных навыков.

\section{Контрольные вопросы}

1. Что такое спорт?

2. Каковы отличительные черты соревновательной деятельности?

3. Какие изменения в функциональном состоянии человека вызывает соревновательная обстановка?

4. Что такое массовый спорт (спорт для всех)?

5. Что такое спорт высших достижений (олимпийский спорт)?

6. Что такое профессиональный (зрелищно-коммерческий) спорт?

7. Какой общественный орган руководит международным студенческим спортивным движением?

8. С какой периодичностью проводятся Всемирные Универсиады (летние и зимние)?

9. Когда состоялась первая Всемирная летняя Универсиада?

10. В каком году г. Москва принимал Всемирную летнюю Универсиаду?

11. Какая общественная организация в масштабах России занимается развитием и управлением студенческого спорта?

\section{Тема 7. Профессионально-прикладная физическая культура}

\section{План:}

7.1. Общая характеристика ППФП.

7.2. Назначение и задачи профессионально-прикладной физической подготовки. 
7.3. Средства профессионально-прикладной физической подготовки, основы методики и формы занятий.

7.4. Применение ППФП для конкретного вида деятельности.

7.5. Рекомендации к разработке комплекса упражнений.

7.6. Возможности развития

\section{1. Общая характеристика ППФП}

Стремление профилировать физическую подготовку применительно к требованиям профессии выразилось, кроме прочего, в создании особой разновидности физической деятельности - профессионально-прикладной физической культуры и культивировании профессионально-прикладных видов спорта. В качестве разновидности физического воспитания профессионально-прикладная физическая подготовка представляет собой педагогически направленный процесс обеспечения специализированной физической подготовленности к избранной профессиональной деятельности. Это такой процесс обучения, который обогащает индивидуальный фонд профессионально полезных двигательных умений и навыков, воспитания физических и непосредственно связанных с ними способностей, от них напрямую зависит профессиональная дееспособность. Типичные для них упражнения и методика их применения характеризуется, с одной стороны, моделированием форм и особенно существенных моментов координации движений, входящих в профессиональную деятельность, а с другой - более направленными и, в конечном счете, более высокими требованиями к двигательным и связанным с ними способностям [9].

Процессу приобретения двигательных навыков (особенно производственных) сопутствует ряд определенных трудностей, которые заключаются в определении интервалов времени, отрезков траектории и 
действий мышечных групп, которые должны быть выбраны для концентрации мышечной силы, изменения функционального состояния двигательного анализатора в соответствии с требованиями рабочих операций. Это отражается в объединении множества сложных рабочих движений, элементов и операций в единую систему - динамический стереотип, в выработке умений правильно планировать и программировать рабочие действия. Рассогласование программы с фактическим выполнением движения особенно выражено при утомлении в сочетании с отрицательными эмоциями.

В комплексе упражнений и методике профессионально-прикладной гимнастики часто преимущественно выражен своего рода аналитический подход, при котором последовательно конструируются необходимые формы движений, и осуществляется избирательно направленное влияние на определенные звенья опорно-двигательного аппарата, его морфофункциональные качества (в частности, силовые, подвижность в суставах, локальную и региональную статическую выносливость), причем исходя не только из требований, предъявляемых профессиональной деятельностью, но и из необходимости профилактики возникающих в ходе еe неблагоприятных воздействий на физическое и общее состояние работника, на что направлены, в частности, гимнастические упражнения, предупреждающие и корригирующие нарушения осанки, обусловленные особенностями рабочей позы.

В профессионально-прикладных видах спорта ярко выражено целостно акцентированное воздействие на развитие двигательных и тесно сопряженных с ними способностей, имеющих существенное значение для совершенствования в профессиональной деятельности. Соответственно ориентированное спортивное совершенствование может оказывать прямое положительное влияние на профессиональную деятельность, при условии, конечно, если предмет спортивной специализации имеет значительную 
общность с профессиональной деятельностью как по операциональному составу действий, так и по характеру проявляемых способностей. Именно это является определяющим при выборе профессионально-прикладных видов спорта представителями той или иной профессии.

Теоретические основы обучения (спортивного и профессионального) разработаны в достаточной степени. В их основе лежат формирование и автоматизация двигательного навыка. В результате автоматизации двигательного навыка обеспечивается четкое, быстрое выполнение движения и вырабатывается способность с наименьшим трудом в возможно меньший промежуток времени сознательно производить наибольшую физическую работу, или действовать изящно и энергично.

Хотя степень интенсивности физических усилий в большинстве современных видов профессиональной деятельности сравнительно невысока и стабильна, в методике построения ППФП следует руководствоваться принципом постепенного прироста тренирующих нагрузок, причем в той мере, в какой это нужно не только для подготовки к конкретным профессионально-трудовым нагрузкам, но и для общего подъема уровня функциональных возможностей организма, укрепления и сохранения здоровья. Здесь так же, как и в физическом воспитании в целом не может быть неких универсальных количественных норм прироста нагрузок, одинаково пригодных во всех случаях, поскольку границы целесообразного увеличения и динамика их зависят от многих переменных обстоятельств, в том числе от реально складывающегося суммарного объема нагрузок и режима занятий физическими упражнениями в индивидуальном образе жизни (например, одни параллельно с ППФП уделяют массу времени и сил углубленным занятиям тем или иным видом спорта, а у других основные занятия физическими упражнениями ограничиваются преимущественно или исключительно рамками ППФП) [15]. 
При организации занятий по ППФП создаются унифицированные программы, разрабатываемыми обычно для групп родственных профессий или отдельных профессий.

Основными формами занятий являются урочные формы, которые имеют обычную в физическом воспитании структуру.

Эффективной формой занятий по ППФП являются соревнования в профессионально-прикладных упражнениях. Соревновательные формы занятий наиболее широко представлены в случае углубленной специализации в избранном профессионально-прикладном виде спорта. Система занятий при этом приобретает характер специализированной спортивной тренировки и регулярного участия в состязаниях, что выдвигает особую проблему рационального сбалансирования спортивной, профессионально-образовательной, и трудовой деятельности. Для спортсменов, не переходящих в сферу спорта, приоритетными должны быть профессионально трудовые навыки.

7.2. Назначение и задачи профессионально-прикладной физической подготовки

Различия в требованиях к физической и психической подготовленности специалистов, разных профессий диктуют необходимость профессионально-прикладной физической подготовки (ППФП).

ПРОФЕССИОНАЛЬНО-ПРИКЛАДНАЯ

ФИЗИЧЕСКАЯ ПОДГОТОВКА - это специализированный вид физического воспитания, направленный на формирование и совершенствование свойств и качеств личности, имеющих существенное значение для конкретной профессиональной деятельности. 
С помощью средств ППФП формируются и совершенствуются различные профессионально важные сенсорные, умственные, двигательные, организаторские и педагогические навыки, приобретаются знания и умения в области физической культуры, обеспечивается высокий уровень функционирования и надежности всех основных органов, систем, психических процессов человеческого организма [20].

Внедрение ППФП в практику физического воспитания создает предпосылки для сокращения сроков профессиональной адаптации, повышения профессионального мастерства, достижения высокой работоспособности и производительности труда, ППФП эффективно содействует укреплению здоровья, повышению устойчивости к заболеваниям, снижению травматизма.

Основными факторами, определяющими общую направленность, задачи и содержание ППФП, являются:

$>$ характер, объем поступающей информации и условия ее восприятия работниками в процессе трудовой деятельности;

$>$ характер основных профессиональных двигательных действий;

$>$ особые внешние условия профессиональной деятельности.

Психофизиологические особенности профессиональной деятельности во многом определяют направленность ППФП. Ими являются: прием, хранение и переработка производственной информации, принятие решений, моторные действия, нагрузка на отдельные физиологические органы и системы, эмоциональные состояния, утомляемость и динамика работоспособности, психические напряжения и др. Изучение этих особенностей позволяет выявить необходимые для успешной работы сенсорные, умственные, двигательные навыки, физические и психические качества, уровень функционирования и надежности отдельных органов и систем организма. 
Определенные условия трудовой деятельности требуют развития соответствующих специальных физических и психических качеств. Так, работа на открытом воздухе при низкой или высокой температуре, резких ее колебаниях требует устойчивости организма к холоду, теплу, резким колебаниям температурных воздействий, общей выносливости, хорошего состояния сердечнососудистой системы, системы терморегуляции. При работе на ограниченной опоре, высоте необходимы чувство равновесия, хорошее состояние вестибулярного аппарата. Продолжительная работа в ограниченном пространстве, однообразной рабочей позе требует статической выносливости мышц спины, туловища, рук, устойчивости к гиподинамии. Профессиональная деятельность в условиях вредного производства (загазованность воздуха, шум, вибрация, укачивание, воздействие радиации и т.п.) определяет развитие специальных качеств, направленных на повышение устойчивости организма к неблагоприятным воздействиям условий внешней среды.

Данные факторы обуславливают основные задачи профессионально-прикладной физической подготовки:

$>$ развитие ведущих для данной профессии физических способностей;

$>$ формирование и совершенствование вспомогательно-прикладных двигательных навыков;

$>$ повышение устойчивости организма к внешним воздействиям условий труда;

$>$ воспитание специфических для данной профессии волевых и других психических качеств;

$>$ повышение функциональной устойчивости и приспособленности организма человека к неблагоприятному воздействию условий труда; 
> содействие формированию физической культуры личности, укреплению ее психики [21].

Решение этих задач непосредственно связано с повышением производительности труда, ускорением процесса врабатываемости, со спецификой двигательной деятельности в трудовом процессе, с его характером (монотонность, статичность, особенности рабочих поз).

Для того, чтобы практически осуществить эту общую направленность ППФП на формирование и совершенствование специфических физических способностей, необходимо иметь достаточно полные данные о профессии. К ним относятся, прежде всего, характеристики собственно производственных движений и действий или профессиограмма. В ее содержание включается подробное описание условий труда, его характера и специфики. Они определяются особенностями рабочих движений, действий и приемов. К ним относятся тип двигательного действия (вращательные, ударные) и участвующие при этом части тела, амплитуда движений, временные и силовые характеристики, особенности координации движений, степень их пластичности и др.

После выяснения основных характеристик, определяющих и раскрывающих типичные черты труда, необходимо определить, как данная профессия воздействует на организм человека, какие физические способности и двигательные навыки являются наиболее профессионально важными (например, для водителя - статическая выносливость, оператора -общая выносливость, буровика - сила, ткачихи - тонкая двигательная координация). Поскольку профессий в настоящие время более тысячи, их унифицируют по условиям труда и характеру двигательной деятельности в группы (например, группа профессий операторского профиля программисты, диспетчеры, операционисты и т.д.). Требования к физическим способностям и двигательным навыкам в этих группах будут 
примерно одинаковыми, хотя узкая специальность их будет иметь определенную специфику.

После того, как выяснены профессионально важные физические способности и определены специфические профессиональные двигательные навыки, подбирают наиболее эффективные средства, содействующие развитию этих качеств. При подборе средств важно учитывать, чтобы данное упражнение по возможности действовало комплексно: решало несколько задач одновременно, развивало физические способности, формировало двигательный навык, способствовало совершенствованию функций организма, его возможности противодействовать влиянию неблагоприятных факторов внешней среды и т.п. Этим требованиям отвечают такие виды физических упражнений, как ходьба на лыжах, бег по пересеченной местности, гребля, плавание и многие другие. Для буровиков, например, профессионально важным качеством является сила. Следовательно, предпочтение необходимо отдавать гимнастическим упражнениям с тяжестями [21, 22].

Очень важным в решении задач ППФП является отбор соответствующих средств, выбор эффективных методов и форм их реализации.

\section{3. Средства профессионально-прикладной физической} подготовки, основы методики и формы занятий

Особое значение при целенаправленном формировании профессионально необходимых свойств и качеств будущего специалиста имеют средства воздействия на организм учащихся. Основным из этих средств являются физические упражнения. Они заимствуются из богатого арсенала основных, подготовительных и специальных упражнений видов 
спорта, общей физической подготовки, лечебной физической культуры и трудовой деятельности.

Физические упражнения, применяемые в целях ППФП, классифицируются по группам. В зависимости от преимущественной направленности их влияния на функциональные системы организма выделяют упражнения, развивающие сердечнососудистую, дыхательную системы, вестибулярный аппарат и т.д. Они в основном берутся из арсенала лечебной и оздоровительной физической культуры. Кроме этого, упражнения можно разделить на развивающие отдельные физические способности: координационные, силовые, скоростные, выносливость, гибкость, а также эмоциональную устойчивость, волевые качества, внимание и т.д. Такие упражнения широко используется в общей физической и спортивной подготовке. Выделяют упражнения для формирования прикладных двигательных навыков: лазанья, работе на высоте, переноске грузов, преодоления препятствий, рациональной ходьбы. Они преимущественно заимствуются из основных и специальных упражнений таких видов спорта, как альпинизм, скалолазание, гимнастика, тяжелая атлетика, туризм, легкая атлетика и др [15].

В качестве средств ППФП могут быть использованы отдельные элементы профессиональной деятельности, например, лазанье и избегание по крутой лестнице для пожарных; самбо, дзюдо, бокс - для оперативных работников.

Для решения задач ППФП широко используются физические упражнения, имеющие достаточно выраженный эффект так называемого неспецифического воздействия. Как уже говорилось, в некоторых профессиях на организм работающего оказывают воздействие ряд неблагоприятных факторов внешней среды (загазованность, недостаток кислорода, резкие перепады температур и атмосферного давления и др.). В этих случаях широко используются бег, плавание, лыжные гонки, гребля и 
другие физические упражнения высокой интенсивности. Они повышают устойчивость организма к недостатку кислорода, активизируют умственную работоспособность, способствуют развитию общей выносливости, которая, в свою очередь, лежит в основе высокоэффективной трудовой деятельности.

В настоящее время определены и широко используются группы специальных физических упражнений, которые достаточно эффективно увеличивают устойчивость организма к неблагоприятным условиям внешней среды. Так, например, устойчивость к гипоксии повышают скоростные циклические виды упражнений (бег, плавание, гонки на велосипеде, бег на коньках), а также упражнения с задержкой дыхания (синхронное плавание, ныряние), альпинизм, горный туризм. Устойчивость к перегреванию повышают спортивные игры, бег в плотной одежде, к укачиванию - упражнения с быстрым изменением положения головы и тела в пространстве (упражнения на гимнастических снарядах, батуте, акробатика, слалом, водные лыжи, фигурное катание на коньках, прыжки в воду и др.), к перегрузкам - упражнение на вращение (на центрифуге, батуте), акробатические прыжки, сальто, фляки, рондаты, стойки на голове и на кистях, упражнения, укрепляющие мышцы живота и ног.

При отборе средств для решения задач ППФП руководствуются следующими принципами:

1. Максимальной реализации задач ППФП.

2. Адекватности и наибольшего переноса качеств и навыков.

3. Обеспечения комплексности решения задач физического воспитания.

Первый принцип предполагает, что выбранное средство в максимальной степени обеспечивает решение задач ППФП. Второй предусматривает использование таких воздействий, которые в наибольшей 
степени улучшают качества и навыки, необходимые специалисту в его профессиональной деятельности. Третий - предполагает, что применяемые приемы для целенаправленного формирования конкретного качества должны попутно улучшать и многие другие жизненно и профессионально важные способности, эффективно содействовать решению основных задач физического воспитания учащихся, не вести к отрицательным последствиям [20].

В основе методики профессионально-прикладной физической подготовки лежит органическое сочетание ОФП и ППФП, причем, последняя имеет в качестве базы определенный, оптимальный для каждой профессии, уровень общей физической подготовки и двигательного опыта.

Необходимо учитывать, что положительное влияние различных физических упражнений на повышение работоспособности специалистов будет зависеть от положительного переноса физических способностей и двигательных навыков. Например, установлено, что у учащихся, занимающихся баскетболом, волейболом, настольным теннисом, повысились показатели нервно-мышечной лабильности, быстроты зрительного различения, тактильной чувствительности, что положительно повлияло на освоение профессии сборщика часовых механизмов. В процессе физических упражнений для мышц одной стороны тела (например, левой руки) повышается работоспособность другой, симметрично расположенной части тела, увеличивается сила, быстрота движений, выносливость данной группы мышц. Перенос способностей может носить не одновременный, а разнородный характер. Например, если под воздействием физических упражнений развивать силу, то это будет способствовать более эффективному развитию быстроты. Перенос двигательных навыков носит более узконаправленный характер, при достаточно высокой степени совпадения он позволяет использовать навыки в усложненных условиях [21]. 
В процессе физического воспитания используются в основном общепринятые формы построения занятий. Так, например, в содержание комплексных уроков включаются общеподготовительные и специально-подготовительные упражнения, тесно связанные со специфическими для данной профессии упражнениями. В таком уроке удельный вес профессионально-прикладных упражнений может быть сравнительно небольшим. В специализированном уроке подбор средств осуществляется для обеспечения целенаправленного воздействия на те способности, навыки и функциональные системы, которые имеют определяющее, профессионально-важное значение.

Кроме урочных форм построения занятий большое значение для реализации профессионально-прикладной направленности физического воспитания учащихся имеет утренняя гигиеническая гимнастика, в содержание которой включаются комплексы специальных упражнений.

Наконец, действенной формой ППФП являются соревнования по видам спорта, которые являются профессионально важными для той или иной специальности (например, для специалистов речного или морского флота соревнования по плаванию, гребле, нырянию).

Занятия с профессионально-прикладной направленностью должны предусматривать не только развитие определенных физических способностей, совершенствование профессионально важных функций организма, но и воздействия физических упражнений на человека в целом, повышение его общей культуры.

\section{4. Применение ППФП для конкретного вида деятельности}

В настоящее время насчитывается несколько тысяч профессий, а специальностей - десятки тысяч. Основные их отличия определяются особенностями предмета, технологии и внешних условий конкретного 
труда и выражаются в специфике трудовой деятельности, входящих в нее операций, действий (в том числе сенсорных и интеллектуальных по восприятию, переработке информации, принятию решений и двигательных по практическому воздействию на предмет труда). Всем этим обусловлены объективно неодинаковые требования к функциональным возможностям, физическим и другим качествам людей, профессионально занимающихся тем или иным видом труда.

Немногие профессии требуют предельной или близкой к ней мобилизации физических способностей в процессе трудовой деятельности (это главным образом профессии, осложненные экстремальными условиями деятельности - испытатели летной и иной транспортно-скоростной техники, профессиональные военнослужащие, оперативные работники следственных органов, водолазы и т.д.). В большинстве же видов профессионального труда, даже физического, требования к физическим возможностям рабочих далеки от максимального уровня. Это не исключает необходимости специализированной физической подготовки в процессе профессионального образования, а во многих профессиях — ив годы основной трудовой деятельности [31].

Требования, предъявляемые рядом распространенных профессий к физическим и непосредственно связанным с ними качествам человека, двигательным способностям и навыкам представлены в таблице 5.

Таблица 6 - Требования профессий к способностям человека

\begin{tabular}{|l|l|l|}
\hline \hline Преимущественно & $\begin{array}{l}\text { Силовые и другие двигательные способности; резистентность } \\
\text { физический труд. }\end{array}$ & $\begin{array}{l}\text { функциональных систем организма по отношению к воздействию } \\
\text { неблагоприятных условий среды (высокой и низкой температур, } \\
\text { высокой влажности воздуха и газовых примесей в нем и др.); }\end{array}$ \\
\hline
\end{tabular}




\begin{tabular}{|c|c|}
\hline & $\begin{array}{l}\text { разнообразные двигательные навыки (в частности, навыки } \\
\text { перемещения в ограниченном пространстве, преодоления } \\
\text { предметных препятствий, поднимания и переноски тяжестей); } \\
\text { психическая устойчивость, базирующаяся, кроме прочего, на } \\
\text { физической кондиции }\end{array}$ \\
\hline $\begin{array}{l}\text { Виды (разновидности) } \\
\text { профессионально-труд } \\
\text { овой деятельности }\end{array}$ & $\begin{array}{l}\text { Профессионально важные физические качества (способности), от } \\
\text { степени развития которых существенно зависит эффективность или } \\
\text { безопасность профессиональной Деятельности }\end{array}$ \\
\hline $\begin{array}{l}\text { Разновидности } \\
\text { двигательно-активного } \\
\text { строительного труда }\end{array}$ & $\begin{array}{l}\text { Выносливость, проявляемая преимущественно в динамических } \\
\text { режимах мышечных напряжений; координационные и другие } \\
\text { двигательные способности; разнообразные двигательные навыки; } \\
\text { закаленность организма по отношению к воздействию меняющихся } \\
\text { условий внешней среды; равновесие тела на узкой и неустойчивой } \\
\text { опоре, в необычных положениях; устойчивость функции сенсорного } \\
\text { контроля, самообладание, базирующееся, кроме прочего, на } \\
\text { физической кондиции }\end{array}$ \\
\hline $\begin{array}{l}\text { Разновидности } \\
\text { станочного труда в } \\
\text { металлообрабатывающ } \\
\text { ей и других отраслях } \\
\text { промышленности } \\
\text { (слесарные, токарные, } \\
\text { фрезерные, швейные и } \\
\text { другие работы) }\end{array}$ & $\begin{array}{l}\text { Неординарно развитая ручная ловкость, способность к мгновенным } \\
\text { двигательным реакциям; общая, региональная и локальная } \\
\text { выносливость (проявляемая при многократном воспроизведении } \\
\text { двигательных действий, в которых участвуют преимущественно } \\
\text { некоторые из звеньев мышечного аппарата - мышцы пояса } \\
\text { верхних конечностей и мышцы, фиксирующие позу); устойчивость } \\
\text { функций зрительного и тактильного контроля: навыки точно } \\
\text { отлаженных движений руками }\end{array}$ \\
\hline $\begin{array}{lr}\text { Разновидности } & \text { труда } \\
\text { подвижного } & \text { состава } \\
\text { ж.д. } & \text { транспорта } \\
\text { включающие } & \text { вначительном } \\
\text { знабъеме } \\
\text { двигательную } \\
\text { активность }\end{array}$ & \begin{tabular}{|l} 
Разносторонняя физическая подготовленность к неординарным \\
проявлениям силовых, скоростных и других двигательных \\
способностей, особенно в экстремальных ситуациях; устойчивость \\
функций вестибулярного аппарата к укачиванию; общая \\
резистентность организма к воздействию неблагоприятных \\
погодных и других внешних факторов; разнообразные \\
двигательные навыки; находчивость, решительность, отважность, \\
базирующиеся, кроме прочего, на отличной физической кондиции
\end{tabular} \\
\hline
\end{tabular}

Уже из этих примеров видно. Что многие из существующих видов профессионального труда предъявляют как в чем-то общие, так и специфические требования и что для достижения высокой результативности в указанных и аналогичных видах труда нужна специально ориентированная физическая подготовка.

\section{5. Рекомендации к разработке комплекса упражнений}


В качестве основных средств ППФП используют довольно разнообразные формы физических упражнений из числа тех, которые сложились в базовой физической культуре и спорте, а также упражнения, преобразованные и специально конструируемые применительно к особенностям конкретной профессиональной деятельности (как специально-подготовительные).

Было бы ошибкой считать, что адекватными средствами могут служить только упражнения, аналогичные по форме профессионально-трудовым двигательным действиям. Сводить лишь к ним средства ППФП, как это делалось в свое время в попытках приблизить физическую культуру к трудовой практике путем простой имитации в занятиях физическими упражнениями отдельных трудовых действий, например молотобойца, землекопа и т.д.,-значит искажать самою ее суть. Особенно мало пригодным такой подход стал в современных условиях, когда для многих видов трудовой деятельности характерны микродвижения, локальные и региональные двигательные действия, сами по себе ни в коей мере не достаточные для оптимального развития двигательных способностей, причем и режим выполнения их зачастую все больше приобретает черты, обусловливающие производственную гиподинамию со всеми ее опасностями для нормального физического состояния организма.

Вместе с тем это не значит, что в современной ППФП вообще нецелесообразно моделировать определенные особенности трудовой деятельности. Однако моделирование не сводится здесь к формальной имитации трудовых операций, а предполагает преимущественное выполнение упражнений, позволяющих направленно мобилизовать (эффективно проявить в действии) именно те профессионально важные функциональные свойства организма, двигательные и сопряженные с ними способности, от которых существенно зависит результативность 
конкретной профессиональной деятельности. При этом бывает целесообразно воспроизводить и существенные моменты координации движений, входящих в состав профессиональной деятельности, но при условии, если соответствующие упражнения могут дать образовательный, развивающий или поддерживающий тренированность эффект как действенные средства реализации хотя бы некоторых из задач, преследуемых в ППФП. Главным образом в силу такого моделирования особенностей профессиональной деятельности состав средств ППФП и приобретает свою специфику [22].

Значительная часть упражнений, используемых в качестве средств ППФП, представляет собой обще (широко)-прикладные упражнения. Таковыми правомерно считать те упражнения, посредством которых вырабатывают двигательные умения и навыки, находящие применение в обычных условиях профессиональной деятельности (часто при выполнении действий вспомогательного характера) или в экстремальных условиях, вероятных в ней. Естественно, что особое место непосредственно прикладные упражнения занимают в ППФП тогда, когда она строятся применительно к профессиональной деятельности, включающей в большом объеме двигательную активность в форме основных, необходимых в обыденной жизни двигательных действий (ходьбу и другие циклические действия по преодолению пространства, поднимание и переноску грузов и т. д.), когда эффективность профессиональной деятельности прямо зависит от разнообразия и отлаженности двигательных навыков как, например, в работе монтажников-высотников, выполняющих немеханизированные операции, a также когда для адекватных действий в экстремальных ситуациях профессиональной деятельности нужны специализированные сложные двигательные навыки. Состав средств ППФП в таких случаях, понятно, наиболее специфичен. 
Менее специфичны те средства ППФП, которые используются преимущественно для воспитания физических качеств и производных от них способностей, так или иначе влияющих на эффективность профессиональной деятельности и обусловливающих ее воздействие на человека. Ведь при осуществлении задач по их воспитанию нужно руководствоваться закономерностями не только прямого, но и косвенного переноса тренировочного эффекта упражнений, используя и общий (неспецифический) эффект адаптации к различным видам мышечной деятельности и факторам внешней среды.

Так для воспитания двигательно-координационных способностей, нужных в сапных видах профессиональной деятельности, в процессе ППФП используют широкий круг разнообразных по форме упражнений; для воспитания общей выносливости - аэробный бег и другие упражнения циклического характера; для повышения уровня работоспособности в деятельности, осуществляемой в условиях высокой внешней температуры, - различные виды упражнений, в процессе выполнения которых существенно возрастает температура тела и Нанимающийся вынужден длительное время противостоять функциональным сдвигам во внутренней среде организма (многократный повторный бег большой и максимальной физиологической мощности и т. д.). ППФП в таких случаях практически сливается с общей физической подготовкой, специализированной в какой-то мере в аспекте профессионального профиля, или спортивной тренировкой в соответственно избранном виде спорта [21].

\section{6. Возможности развития}


Причины и обстоятельства, необходимые для дальнейшего совершенствования и внедрения ППФП в систему образования и сферу профессионального труда:

1. время, необходимое на освоение современных практических профессий, и достижение профессионального мастерства в них в большей степени зависит от уровня функциональных возможностей организма, от степени развития физических способностей индивида, разнообразия и совершенства приобретенных им двигательных умений и навыков.

2. несмотря на снижение доли мышечных усилий в современном материальном производстве, производительность достаточно многих видов профессионального труда прямо или косвенно остается зависимой от физической дееспособностью исполнителей трудовых операций, причем не только в сфере преимущественно физического труда, но и в ряде видов трудовой деятельности смешанного (интеллектуально-двигательного) характера, как у наладчиков машинных устройств, монтажников и т.д.;

В целом же стабильное физическое состояние, без которого не мыслится здоровье и эффективное функционирование организма человека, остается важнейшей предпосылкой устойчиво высокой плодотворности любого профессионального труда;

3) все еще остается проблема негативного влияний определенных видов профессионального труда и его условий на физическое состояние трудящихся; хотя эта проблема решается многими средствами оптимизации содержания и условий труда, в том числе социальными, научно-техническими и гигиеническими, важную роль среди них призваны играть факторы профессионально-прикладной физической культуры;

4) социальный и научно-технический прогресс заставляют человека постоянно совершенствовать свои профессиональные навыки и способности. Их развитие неотделимо от физического совершенствования индивида. 
Таким образом, большинство принятых в системе физического воспитания и самовоспитания форм занятий может быть использовано в той или иной мере в целях ППФП. Вместе с тем содержание их определяется не только требованиями профессиональной деятельности и не замыкается на ней. ППФП непременно нужно рассматривать в единстве с другими слагаемыми целостной системы воспитания и в зависимости от их характера в индивидуально-конкретном выражении находить наиболее оправданное на том или ином этапе соотношение различных форм занятий, позволяющих реализовать личностно и социально значимые цели.

\section{Контрольные вопросы}

1. Что такое профессионально-прикладная физическая подготовка (ППФП)?

2. Какова цель ППФП?

3. Какие задачи у ППФП?

4. На какие группы можно условно разделить профессии?

5. Какие основные физиологические показатели необходимо учитывать при оценке степени тяжести труда? 


\section{БИБЛИОГРАФИЧЕСКИЙ СПИСОК}

1. Айзман, Р.И. Здоровье населения России: медико-социальные и психолого-педагогические аспекты формирования [Текст] / Р.И. Айзман. Новосибирск, 1996.

2. Амосов, Н.М. Раздумья о здоровье [Текст] / Н.М. Амосов. - М, 1987.

3. Амосов, Н.М., Муравов, И.В. Сердце и физические упражнения [Текст] / Н.М. Амосов, И.В. Муравов. - М., 1985.

4. Брехман, И.И. Валеология - наука о здоровье [Текст] / И.И. Брехман. - М.,1990.

5. Вайнбаум, Я.С. Гигиена физического воспитания [Текст]: Учеб. пособие для студентов фак. физ. восп. мед. Институтов / Я.С. Вайнбаум. M., 1986.

6. Вайнер. Э.Н. Валеология [Текст]: Учебник для ВУЗов / Э.Н. Вайнер. - М., 2002.

7. Верхошанский, Ю.Ф. Программирование и организация тренировочного процесса [Текст] / Ю.Ф. Верхошанский. - М.: Физкультура и спорт, 1985. - 176 с.

8. Виленский, М.Я. Физическая культура в научной организации учебного труда студентов [Текст] / М.Я. Виленский. - М., 1993.

9. Виленский, М.Я., Ильинич, В.И. Физическая культура работников умственного труда [Текст] / М.Я. Виленский, В.И. Ильинич. - М., 1987.

10. Гулько, Я.Н. Социально-биологические основы физической культуры [Текст] / Я.Н. Гулько. - М., 1994.

11. Евсеев, Ю.И. Физическая культура [Текст]: Учебное пособие для студентов вузов / Ю.И. Евсеев. - Ростов н/Д: Феникс, 2004 г.

12. Евсеев, Ю.И. Основы гигиены и самоконтроля [Текст] / Ю.И. Евсеев. - Ростов н/Д, 1988. 
13. Евсеев, Ю.И., Асланов, В.А., Кравченко, П.В. Самостоятельная физическая подготовка студентов полевых специальностей [Текст] / Ю.И. Евсеев, В.А. Асланов, П.В. Кравенко. - Ростов н/Д, 1988.

14. Ильинич, В.И. Студенческий спорт и жизнь [Текст] / В.И. Ильинич. - М.: АО «Аспект Пресс», 1995. - 183 с.

15. Кабачков, В.А., Полиевский, С.А. Профессионально-прикладная физическая подготовка учащихся в средних ПТУ [Текст] / В.А. Кабачков. М.: Высшая школа, 1982.

16. Купер, К. Новая аэробика [Текст] / К. Купер. - М., 1979.

17. Лисицын, Ю.П. Образ жизни и здоровье населения [Текст] / Ю.П. Лисицын. - М., 1982.

18. Лищук, В.А., Мостовая, Е.В. Обзор основ здоровья [Текст] / В.А. Лищук, Е.В. Мостовая. - М., 1994.

19. Лоранский, Д.Н., Лукьянов, В.С. Азбука здоровья [Текст] / Д.Н. Лоранский, В.С. Лукьянов. - М.: Профиздат, 1990.

20. Могендович, М.Р. Достижение теории и практики учения о моторно-висцеральных рефлексах [Текст] / М.Р. Могендович. - Вильнюс, 1972.

21. Раевский, Р.Т. Профессионально-прикладная физическая подготовка студентов технических вузов [Текст] / Р.Т. Раевский. - М.: Высшая школа, 1985.

22. Раевский, Р.Т. Профессионально-прикладная физическая подготовка студентов технических вузов [Текст] / Р.Т. Раевский. - М.: Высшая школа, 1987 г.

23. Решетников, Г.С. Ваши мышцы [Текст] / Г.С. Решетников. - М.: ФиС, 1977. - 164 с.

24. Соколов, П.П., Герасимов, Ю.Н. Помоги себе сам [Текст] / П.П. Соколов, Ю.Н. Герасимов. - М.: ФиС, 1992. 
25. Тамбиан, Н.Б. Самоконтроль спортсмена [Текст] / Н.Б. Тамбиан. М.: ФиС, 1998.

26. Теория и методика физической культуры [Текст]: Учеб. пособие / Под ред. Ю. Ф. Курамшина, В. И.Попова. - СПб, 1999. - 324 с.

27. Тиселевич, В.А. Регулирование веса спортсмена [Текст] / В.А. Тисалевич. - М.: ФиС, 1967.

28. Трещева, О.Л. Формирование культуры здоровья в условиях современного образования [Текст]: Монография / Под ред. О.Л.Трещевой. - Омск, 2002. - 268 с.

29. Физическая культура студента [Текст]: Учебник / Под. ред. В.И. Ильинича. - М.: Гардарики, 2000. - 448 с.

30. Физическая культура [Текст]: Учебник / Под. ред. Ю. И. Евсеева. - Ростов-н/Д: Феникс, 2003. - 384 с.

3.1 Холодов, Ж.К., Кузнецов, В.С. Теория и методика физического воспитания и спорта [Текст]: Учеб. Пособие / Ж.К. Холодов, В.С. Кузнецов. - М.: Академия, 2001. - 479с. 


\section{ЧАСТЬ ІІ. ПРАКТИЧЕСКИЕ РАБОТЫ ПО ИЗУЧЕНИЮ КУРСА}

Тема 3. Основы методики самостоятельных занятий физическими упражнениями. Самоконтроль при занятиях физической культурой и спортом

Практическая работа № 1. Выбор физических упражнений и их систем для самостоятельных занятий.

\section{Задачи:}

1. Ознакомить с жизненно необходимыми умениями и навыками, лежащими в основе самостоятельных занятий.

2. Охарактеризовать нетрадиционные системы физических упражнений.

3. Выявить индивидуальные особенности для обоснования индивидуального выбора физических упражнений.

\section{Технология выполнения работы}

1. Ознакомьтесь с основными теоретическими положениями

В своем историческом развитии организм человека формировался в условиях высокой двигательной активности. Первобытному человеку ежедневно приходилось пробегать и проходить десятки километров в поисках пищи, постоянно от кого-то спасаться, преодолевать препятствия, нападать. Так выделились основные жизненноважные движения, каждое из которых имело свое значение: бег и ходьба для перемещения в пространстве, прыжки и лазание - для преодоления препятствий, метание - для защиты и нападения. Миллионы лет эти движения являлись главнейшим условием существования человека - выживал тот, кто лучше владел ими. 
Основные движения - это сложные условные рефлексы, постепенно образующиеся в процессе обучения, воспитания. С возрастом основные движения развиваются, совершенствуются и закрепляются в двигательные стереотипы. Движение как моторная функция организма - это изменение положения тела или его частей. Отдельное движение является элементом действия. Посредством связанных между собой движений осуществляется действие.

Двигательное действие - это движение (перемещение тела и его звеньев), выполняемое с определенной целью.

Двигательное умение - уровень владения движением, при котором сознание контролирует технику его выполнения.

Двигательный навык - уровень владения движением, при котором сознание контролирует условия, в которых данное движение выполняется.

Многократное повторение движений в определенной последовательности образуют между отдельными элементами каждого из этих движений временные связи. Суставномышечная сигнализация, начинающаяся от выполнения начального движения, непосредственно вызывает все последующие, которые закрепляются в систему, автоматизируются. Образовавшиеся при том двигательные стереотипы обладают большой устойчивостью.

Физические упражнения - это двигательные действия, созданные и применяемые для физического совершенствования человека.

Техника физического упражнения - это наиболее эффективный способ выполнения двигательного действия.

Основные движения - это жизненно необходимые для человека движения, которыми он пользуется в своей многообразной деятельности: ходьба, бег, прыжки, метание, лазание. Постоянным, необходимым компонентом этих движений является чувство равновесия. Кроме этого существуют оздоровительные, общеразвивающие и прикладные виды 
упражнений. Это ходьба на лыжах, плавание, туризм, гимнастика, подвижные и спортивные игры.

Легкая атлетика

Упражнения легкой атлетики, в основе которых лежат естественные движения человека - ходьба, бег, прыжки и метания, способствуют совершенствованию этих жизненно важных умений и навыков. Они повышают функциональные возможности всех органов и систем, в особенности нервно-мышечной, сердечно-сосудистой, дыхательной, т. е. тех, которые в наибольшей степени обеспечивают успех в любом виде физической деятельности. Различные упражнения легкой атлетики развивают у человека важные физические качества: быстроту, выносливость, ловкость и силу, а также воспитывают морально-волевые качества, упорство в достижении цели, умение преодолевать трудности, силу воли и др.

\section{Ходьба}

Ходьба - самый распространенный способ передвижения. В нем сохраняется постоянная опора о землю одной или двумя ногами. В ходьбе активно участвует весь опорно-двигательный аппарат, одновременно в работу включается до 50\% мышц тела. При соблюдении правильной техники ходьбы значительно укрепляются мышцы туловища, спины и живота, тренируются мелкие мышцы стопы, формируется правильная осанка; тренируется дыхательная и сердечно-сосудистая системы; активнее происходит процесс обмена веществ; развивается согласованность движений, организованность, умение ориентироваться в разнообразных и часто меняющихся условиях местности.

В спортивной деятельности применяется спортивная ходьба. Она позволяет значительно увеличить скорость передвижения при соблюдении определенных правил соревнований. Соревнования по ходьбе проводятся 
на дорожках стадиона и на обычных дорогах, на дистанциях $3,5,10,20,50$ Км.

Ходьба может обеспечить сравнительно высокую функциональную нагрузку, тренировку и укрепление сердечно-сосудистой системы Тренирующий эффект во многом зависит от скорости и продолжительности передвижения. Медленная ходьба (до 70 шагов в минуту) почти не дает тренирующего эффекта для здоровых людей. Ходьба со средней скоростью $3-4$ километра в час, т. е. 70-90 шагов в минуту, относится к средней скорости. Она обеспечивает определенное повышение тренированности для слабо подготовленных людей.

Ходьба в темпе 90-100 шагов в минуту (4-5 км/ч) считается быстрой и оказывает тренирующий эффект. Темп 110-130 шагов в минуту очень быстрый. Определение темпа ходьбы через число шагов, конечно, условно.

Бег

Бег чаще других движений используется в повседневной жизни. Он входит в содержание многих видов движений. От умения правильно выполнять бег зависит успешность в других видах спорта: прыжках, спортивных играх и т.п. В процессе бега происходит попеременное сокращение и расслабление большого количества мышечных групп. При беге резко возрастает расход энергии, поэтому увеличивается объем дыхания, скорость кровообращения, газообмен. Правильно дозированный бег способствует общему физическому развитию, совершенствованию функции центральной нервной системы, тренировке сердечно-сосудистой и дыхательной систем. Как и ходьба, бег является упражнением циклического типа, в котором отталкивание от опоры ногой чередуется с полетом. Это является отличительным признаком бега в сравнении с ходьбой. В беге, как и в ходьбе, необходима хорошая координация 
движений рук и ног, правильная осанка, целесообразная в зависимости от вида бега постановка ноги на опору.

В спортивной практике бег делится в зависимости от длины дистанции: спринт(30- 100 м), бег на средние дистанции (400-1000 м), бег на длинные дистанции (от 2000 м), марафонский бег. Кроме этого различают бег кроссовый, с препятствиями, барьерный; в оздоровительных целях - бег в невысоком темпе (трусцой).

Оздоровительный бег Этот вид бега является наиболее простым и доступным видом циклических упражнений. Его популярность объясняется естественностью движений и доступностью для людей всех возрастов, для мужчин и женщин. Бегать можно в любую погоду, группой и в одиночку. Нагрузка в беге легко дозируется по самочувствию или по показателям пульса. С помощью продолжительного спокойного бега быстро достигается ощутимый оздоровительный эффект; улучшается самочувствие, повышается работоспособность, восстанавливаются утраченные физические качества, повышается выносливость человека. Занятия могут проводиться индивидуальным и групповым методом.

Бегом можно заниматься индивидуально или в группах в любое время дня. При этом не требуются ни инвентарь, ни специальные спортсооружения. Возраст и пол значения не имеют. Перед тем как начинать заниматься бегом, необходимо проконсультироваться с врачом. Необходимо подобрать соответствующую одежду и обувь, определить место для занятий бегом (парк, сквер, тихая улица). Не следует торопиться: сначала надо как можно больше ходить, затем чередовать бег с ходьбой. Не рекомендуется следовать советам по дальности и продолжительности бега; организм сам подскажет оптимальные параметры. Обычно рекомендуется частота занятий от 3 до 5 раз в неделю. Длительность бега от 15 до 30 минут. Бег способствует сохранению активного периода жизни с высокой работоспособностью и хорошим самочувствием 


\section{Плавание}

Плавание имеет прикладное значение в трудовой деятельности человека. Умение плавать является жизненно необходимым для людей, трудовая деятельность которых связана с работой у воды, на воде или в воде (моряки, водолазы, строители гидротехнических сооружений, рыбаки). Умение плавать, нырять, переправляться через водоемы в одежде и без нее, с помощью подручных средств и без них, умение оказать помощь товарищу, попавшим в беду, являются жизненно важными навыками человека. Плавание многообразно. Оно включает в себя спортивное, прикладное, синхронное, подводное, игровое плавание и прыжки в воду. Спортивное плавание объединяет четыре основных вида: вольный стиль (кроль), плавание на спине, брасс, дельфин (баттерфляй). Лыжный спорт

Навыки передвижения на лыжах широко используются в военном деле, в быту и в труде. Физические качества, воспитанные человеком в ходе занятий лыжным спортом, способствуют успешному выполнению таких дел, в которых человеку требуются выносливость и закаленность к холоду, быстрота передвижения на местности в условиях бездорожья, решительность действий. Этим объясняется широкая общая прикладность различных видов спорта - гонок и скоростного спуска, слалома и прыжков с трамплина, лыжной акробатики других видов. Лыжный спорт находит непосредственную прикладность в ряде профессий: лыжами пользуются охотники на промыслах, к месту работы на лыжах добираются часто строители отдаленных таежных строек, не обходятся без лыж зимой геологи и т.п.

Лыжный спорт также имеет большое оздоровительное, воспитательное значение, оказывая разностороннее влияние на организм занимающихся. Передвижение на лыжах доступно в любом возрасте, с малых лет и до пожилого. Физическая нагрузка при занятиях на лыжах 
легко дозируется в самых широких границах, как по характеру воздействия, так и по объему и интенсивности. Это позволяет использовать лыжный спорт для людей любого возраста, пола, состояния здоровья и уровня физической подготовленности.

Для занятий лыжной подготовкой необходимо правильно подобрать лыжи, палки, ботинки и соответствующую одежду.

Занимаясь лыжным спортом дозировать нагрузку можно, ориентируясь на общее время ходьбы и частоту пульса. Скорость же передвижения часто зависит от погодных условий, снежного покрова, рельефа местности. Проводить лыжные прогулки лучше в свободные дни. Двигаясь с небольшой приятной для себя скоростью, можно преодолеть от 5 до 20 километров. Первые прогулки желательно совершать в течение $1,5-2$ часов, увеличивая это время по мере нарастания тренированности.

Велосипедные прогулки, гребля, катание на коньках — прекрасные средства оздоровления. Циклический характер движений позволяет регулировать общую нагрузку, повышая или снижая eе при необходимости.

\section{Гимнастика}

Оздоровительное, общеразвивающее и профессионально-прикладное значение гимнастики заключается в том, что ее упражнениями воспитываются такие физические качества, как мышечная сила, ловкость, гибкость и др.; формируются эстетически привлекательные формы тела, умение владеть своим телом в пространстве сохранять и восстанавливать равновесие при разнообразной и меняющейся позе, выполнять точные движения отдельными частями тела; воспитываются морально-волевые качества - смелость, самообладание, решительность при оправданном риске. Все эти качества и свойства профессионально необходимы представителям многих профессий. Гимнастические упражнения помогут избежать негативных явлений работникам, связанным с малоподвижным 
характером работы. На основе гимнастических упражнений составляются комплексы УГГ, физкультурной паузы, разминки на тренировочных занятиях и т. д.

Спортивные игры

В ходе занятий спортивными играми воспитываются оптимальные двигательные реакции на различные раздражители - световые, звуковые, тактильные (чувствительные)- и др. Это имеет большое значение в приспособлении человека к работе на современных машинах и механизмах, так как новая техника предъявляет высокие требования именно к быстроте реакции. Эти качества необходимы в работе операторов вычислительных машин и пультов АСУ, рабочих у станков с программным управлением, водителей различных транспортных средств и других профессий, где требуется повышенная быстрота ответных реакций на внезапное появление объекта, срочность выбора и принятия решения. Для развития этих качеств и являются полезными спортивные и подвижные игры, различные виды спортивных единоборств.

Туризм

Туризм имеет большое образовательное, оздоровительное и прикладное значение. Умение ориентироваться на местности с картой и компасом, по природным ориентирам и местным предметам, по народным приметам имеет большое значение в военном деле, в мирном труде специалистов ряда профессий. Ловкость, физическая выносливость, воспитываемые туристскими походами, находят применение практически всюду. Туризм является неизменным средством активного отдыха для людей напряженного умственного труда. Туристские походы обладают исключительно благоприятными возможностями для восстановления сил и укрепления здоровья. Умеренные физические нагрузки, положительные эмоции от общения с природой оказывают благотворное влияние на нервно-эмоциональную сферу, деятельность сердечно-сосудистой, 
мышечной, дыхательной систем организма. По способу передвижения на маршруте походы выходного дня и многодневные путешествия делят на пешеходные, горные, водные (на плотах, гребных или моторных судах), лыжные, велосипедные, мотоциклетные, автомобильные, спелеологические (изучение пещер) и т.д. Туристические походы различают по категориям сложности на основе классификации маршрутов по видам туризма. Сложность маршрута зависит от его общей длины, протяженности участков с естественными препятствиями.

Для достижения оздоровительного эффекта туристских походов необходимы знания и выполнение определенных требований руководителями походов, соблюдение туристами правил рациональной тренировки и закаливания организма.

Нетрадиционные виды физических упражнений и спорта

Акватлон включает в себя два раздела: спортивный и боевой. Спортивный раздел представляет собой плавание под водой на время в ластах, ориентирование под водой и т.п.; боевой - борьбу под водой. Эти два направления развивают выносливость, силу, морально-волевые качества. Соревнования проводятся с 1982 г. Клубы любителей акватлона объединились в ассоциации и предполагают выйти в международные воды.

Акробатический рок-н-ролл. Как танец рок-н-ролл популярен вот уже более 25 лет. Сначала рок-н-ролл являлся танцем-монологом, затем его стали танцевать группой, после чего рок-н-ролл становится танцем-диалогом мужчины и женщины. По мере совершенствования техники танца в него включались элементы акробатики, и рок-н-ролл становится массовым видом спорта. Существует Всемирная федерация рок-н-ролла. Она насчитывает в своем составе около тридцати стран-участниц. Ежегодно проводится более 20 международных турниров, в том числе - чемпионаты мира, Европы, кубки мира и Европы и др. Все 
большей популярностью пользуется рок-н-ролл в нашей стране. Многие элементы этого танца могут быть использованы для занятий с оздоровительными целями.

Армрестлинг - борьба руками на столе: высотой - 104,14 см, длиной - 92,71 см, шириной - 64,77 см. На столах на одинаковом расстоянии от краев и перпендикулярно к ним располагаются «контейнеры» для локтевого сустава борцов. Они имеют П-образную форму $(15,24 x 15,24$ см) и выступают над поверхностью стола на 3,81 см. По армрестлингу регулярно проводятся чемпионаты мира, на которых спортсмены выступают по четырем группам: мужчины-правши, мужчины-левши, женщины-правши, женщины-левши. Соревнования проводятся в различных весовых категориях: для мужчин в весе - до 59 кг, до 68 кг, до 80 кг, до 90 кг и свыше 90 кг. Для женщин - До 61 кг, до 80 кг, свыше 80 кг. Армрестлинг начинает получать распространение и в нашей стране. В Москве создана федерация по этому виду борьбы, проводятся чемпионаты Москвы и других регионов.

Бейсбол (в переводе с англ. бейс - база, бол - мяч). Игра проводится на площадке, представляющей собой сектор, в котором имеется внутреннее поле в виде квадрата со сторонами длиной 27 м 45 см. По углам квадрата расположены базы, внутри квадрата размечен круг, откуда мяч вводится в игру. Игра напоминает русскую лапту, когда игрок после отбивания мяча пробегает по базам. Одновременно играют две команды, время игры не ограничено. Побеждает та команда, которой удается за девять иннингов (в ходе каждого иннинга соперники по одному разу играют в нападении и в обороне) совершить большее количество полных пробежек по базам и таким образом набрать большее количество очков. Ничьих в бейсболе не бывает, если к окончанию девяти иннингов счет равный, то назначается десятый, одиннадцатый и т.д., пока не 
определится победитель. Играть в бейсбол можно практически в любом возрасте.

Боулдринг (болдринг, болдеринг) лазание по отдельным скальным блокам максимальной сложности без страховки (на высоте $1-3$ м). Боулинг - цель игры, катнув шар по специально оборудованной дорожке сбить максимальное количество кеглей.

Гидроаэробика - выполнение физических упражнений в воде, является эффективным средством повышения уровня физической подготовленности для лиц с различным физическим развитием и практически любого возраста. Структура занятий, дозирование физической нагрузки, музыкальное сопровождение могут быть такими же, как при занятиях ритмической гимнастикой. Однако сопротивления воды усложняют движения, и его преодоление приводит к более быстрому, чем на суше, развитию силы различных мышечных групп. Гидроаэробика особенно полезна тем, кто стремится похудеть. Систематическое выполнение физических упражнений в воде нормализует деятельность нервной и сердечно-сосудистой систем, снимает излишнюю возбудимость, улучшает сон, делает кожу эластичной и упругой. Дайдинг - подводная охота, плавание, отдых и т.д.

Джаз-гимнастика. В последние годы под влиянием джазовой музыки началось увлечение джаз-гимнастикой как средством физического воспитания. Возникновение этого направления связано с именем известной американской танцовщицы Айседоры Дункан. Она считается пионером современного сценического джазового танца. Особенность ее искусства заключалась в возрождении античного танца, построенного по законам свободной пластики, введении в танец элемента пантомимы. Оно оказало значительное влияние на формирование различных форм танцевальной ритмикопластической гимнастики. Характерной особенностью джаз-гимнастики является то, что, помимо традиционных средств, в ней 
широко используются элементы джазового танца, который развивался и распространялся одновременно с джазовой музыкой. Джазовый танец так же, как и музыку, создали американские негры, соединившие основные элементы африканских танцев с движениями европейского танца. Европейский способ танца требует от танцора удержания туловища выпрямленным, с повышенным тонусом брюшного пресса, спины. Эти же черты характерны и для европейской гимнастики. Африканские же танцоры, наоборот, танцуют расслабленно, создается впечатление, что все движения вытекают из абсолютно расслабленных положений, различные части тела двигаются независимо друг от друга, часто с различной скоростью, с разной амплитудой. Джаз-гимнастика отлично развивает координацию движений, умение управлять своим телом, расслаблять мускулатуру, красиво танцевать современные танцы. Движения джаз-гимнастики являются прекрасным средством укрепления суставов.

Диско-гимнастика. В основе диско-гимнастики лежат элементы, характерные для танцев в стиле диско: шаги вперед, в сторону, назад, подскоки, простейшие повороты, выполняемые в единстве с ритмом музыки. По воздействию на организм занимающиеся диско-гимнастикой приравниваются к таким видам двигательной активности, как бег трусцой (джоггинг), катание на лыжах со скоростью 8-9 км/ч, плавание со скоростью 2,5-3 км/ч, езда на велосипеде со скоростью 20-25 км/ч. Диско-гимнастика может быть использована как средство снижения массы тела.

Йога. Слово «йога», в переводе с древнегреческого языка означает «союз, соединение, связь, единение, гармония». Философы-материалисты трактуют этот термин как единение; гармонию физического и психологического состояния человека, как гармонию полного физического здоровья и духовной красоты человека. Упражнения, основанные на понимании не только физических, но и духовных, нравственных правил 
усовершенствования личности, - это и есть система йоги. Известно великое множество еe разновидностей, разделов, упражнений хатха-йога, раджа-йога, бхагги-йога, Тантрайога. Наиболее важны для понимания на первоначальном этапе освоения йоги Пранаяма - основные дыхательные упражнения и Санкахья - философская основа йоги, а знаменитые асаны йоги - это не просто принятие различных замысловатых поз и расслабление, а настоящая сложная техника контроля над телом и концентрация внимания на нем.

Каратэ - древнейшее военное искусство Востока. В наши дни стало одним из видов спортивного единоборства и получило широкое распространение во всем мире. Оно является лишь состязанием в демонстрации бойцовской техники. Это как бы фехтование на руках и ногах с имитацией ударов по жизненно важным точкам человеческого тела. Искусство бойца заключается в том, чтобы удар рукой или ногой максимальной быстроты и силы в одну из этих точек был остановлен в миллиметре от тела соперника и чтобы боец, наносящий удар, мгновенно занял затем исходное положение. Главное скорость и концентрация максимальной силы в момент удара. Малейшее касание тела соперника строжайше наказывается. Основа обучения карата - максимальная дисциплина, полный контроль спортсменов за своими движениями.

Керлинг - возник в Шотландии еще в XVI в., но получил широкую популярность и признание лишь в нашем столетии. Сейчас в керлинг играют более чем в 15 странах, а в Канаде, Шотландии, США, Швейцарии, Швеции наблюдается массовое увлечение этой игрой. В керлинг могут играть люди в возрасте от 7-10 до 75-80 лет. Для игры на ледяной дорожке длиной 43,93 м и шириной 4,27 м размечаются два «дома», представляющих собой три концентрические окружности синего, белого и красного цветов. Играют в керлинг круглыми, выпуклыми сверху и снизу 
камнями, имеющими сверху прочно закрепленную рукоятку. Общая масса снаряда составляет 20 кг.

Играют две команды по 4 игрока. Каждый игрок бросает по два камня в каждом туре (игра состоит из 8-12 туров). Команда получает очко за каждый камень, остановившийся в доме на меньшем расстоянии от центра, чем камень противника. После того, как сделан бросок, партнеры имеют право специальной щеткой расчищать лед в шестиметровой зоне от центра дома. Керлинг способствует развитию силы, ловкости, быстроты движений, умения владеть своим телом.

Пауэрлифтинг — это троеборье, состоящее из приседания со штангой, жима штанги лежа и тяги штанги. Чемпионаты мира по этому виду троеборья проводятся Международной федерацией пауэрлифтинга с 1975 г. Спортсмены нашей страны впервые приняли участие в чемпионате мира в 1990 г. и заняли 3-е командное место. Командный результат определяется достижениями шести участников, занявших наиболее высокие места в каждой из одиннадцати весовых категорий.

Перетягивание каната как организованный вид спорта возник в 70-х гг. прошлого века в Англии. В 1900 г. в Париже и в 1912 г. в Стокгольме перетягивание каната входило в программу Олимпийских игр. После 1963 г., когда была создана Международная федерация этого вида спорта, наступает новый этап его широкого распространения, и он успешно развивается более чем в двадцати странах мира. Команды соревнуются в пяти весовых категориях; легкой (общий вес участников до 560 кг), полусредний (до 640 кг), средний (до 680 кг), полутяжелый (до 720 кг) и тяжелый (до 800 кг). Каждая команда состоит из 8 человек и капитана, который непосредственного участия в перетягивании каната не принимает, а руководит действиями своих товарищей. Канат должен быть не менее 35 м длиной и от 10 до 12,5 см - в окружности. Белые флажки по краям коридора, в котором происходит перетягивание, отмечают середину каната, 
а красные, расположенные на расстоянии двух метров от середины, - ту линию, за которую команда должна перетянуть своих противников, чтобы выиграть. При этом запрещается тянуть канат лежа на земле. Такое нарушение правил наказывается предупреждением, a за три предупреждения команда дисквалифицируется. В соревнованиях среди женщин имеется только одна весовая категория - свободная, или открытая, т.е. без ограничения веса участниц. Во время соревнований женщинам разрешается пользоваться перчатками.

Сепактакроу - волейбол без игры руками. Все большую популярность в странах Юго-Восточной Азии приобретает старинный вид спорта сепактакроу, что в переводе с малайского значит «игра ногой в мяч». В игре участвуют две команды по пять человек, располагающиеся на площадке, равной по размеру корту для бадминтона, с сеткой. Мяч рукой набрасывается на ногу подающего игрока своей команды, а соперники принимают мяч ногой или головой (руками можно только подавать). Далее действуют волейбольные правила счета и трех передач своей площадке. Игра начинает распространяться и в западных странах.

Сквош напоминает бадминтон, только игра проводится в «коробке» с бортами более высокими, чем при игре в хоккей. Ракетки несколько более массивные, чем при игре в бадминтон, мяч диаметром 4 см изготовляется из черной резины. Счет ведется так же, как при игре в бадминтон. В сквош играют более 10 миллионов человек почти в ста странах мира.

Скейтбординг — катание на доске с роликами. Занятия проводятся на площадках с асфальтовым или другим ровным покрытием с участками, имеющими уклоны различной крутизны. Занятия скейтбордингом укрепляют голеностопные, коленные и тазобедренные суставы, способствуют совершенствованию равновесия, развивают ловкость, гибкость, силу, выносливость, быстроту движений. 
Снежный серфер (монолыжа) - спуски с гор по снегу на одной лыже с выполнением различных поворотов. Лыжа короткая и широкая, ее передняя часть круто загнута вверх, несколько загнут и задник. Скользящая поверхность имеет десять металлических катов. Стоять на монолыже на большой скорости помогают вёревочные «вожжи» с деревянной ручкой, прикрепленные к носку лыжи и в ее центре.

Стретчинг растягивание, включает в себя комплекс поз, способствующих повышению эластичности различных мышечных групп. Для правильного выполнения упражнений стретчинга следует придерживаться следующих требований: прежде чем выполнить упражнение, надо знать, какую конкретную группу мышц оно помогает растягивать; при выполнении упражнений не следует пытаться скопировать движение более гибкого товарища, все движения должны находиться в определенных пределах, индивидуального диапазона подвижности суставов, вначале следует применять « легкий стрейчинг» при положении сустава в крайне разогнутом, согнутом, отведенном или приведенном положении не покачиваться, растягивать связки и мышцы только за счет статического давления, находясь в неподвижном состоянии; в процессе выполнения упражнений дышать спокойно и ритмично; при появлении острых болевых ощущений прекращать выполнение упражнений. Этот вид гимнастики широко используется как вспомогательное средство в различных видах спорта.

Сумо — японский национальный вид единоборства, насчитывающий тысячелетнюю историю. Задача борца - вытолкнуть соперника из круга или заставить его коснуться пола. Существует около полусотни классических приемов, с помощью которых можно вытолкнуть противника из круга или бросить на землю. Выступлениям борцов предшествует традиционная церемония - «вхождение в круг», которая 
служит своеобразной разминкой, а также психологически подготавливает зрителей. Разминка длится четыре минуты.

Треккинг - поход с прохождением ледников и несложными восхождениями на сравнительно больших высотах $(3000-6000$ м) в неальпинистском районе.

Триатлон (троеборье) включает в себя плавание, велосипедный кросс и бег. Соревнования проводятся в один день без перерыва между видами троеборья. Классический триатлон, культивируемый в международной спортивной практике, включает: плавание - на 3,8 км, велокросс - на 180 км, бег - 42 км (классическая марафонская дистанция). В нашей стране триатлон начинает получать широкое распространение, создана спортивная федерация триатлона, отдельных регионах проводятся массовые соревнования, проводится чемпионаты среди студентов вузов. Программа триатлона может быть различной, ее могут определять сами спортивные коллективы. Наиболее распространенными программами являются: плавание - 1 км, велокросс - 50 км, бег - 25 км или: плавание - 1,5 км, велокросс - 40 км, бег - 10 км.

Ушу - древняя китайская гимнастика, имеющая несколько стилей, начиная от комплекса оздоровительной гимнастики кончая боевым искусством. Ушу включено в систему обучения в школах и некоторых вузах Китая. Ушу объединяет различные виды упражнений, которые можно выполнять с оружием и без оружия, с партнером или без него. Существует две школы — внешняя и внутренняя. Внешняя школа предполагает твердые и силовые движения, быстроту реакции, гибкость, реактивные прыжки. Внутренняя школа подчеркивает мягкие, грациозные, плавные движения, которые подобны танцу. Упражнения внутренней школы включают плавные движения, подобные изометрическим, которые уже получили широкое распространение в западных странах. 
Фитнес-аэробика. Это образ жизни, ведущий к физическому и ментальному здоровью человека. Аэробика является частью фитнеса. Современная аэробика отличается разнообразием направлений.

1. «Скульптура тела» - танцевальные занятия с резиновыми лентами.

2. «Кардиофанк - танцевальные занятия для укрепления сердца.

3. «Степ» - занятия на специальной платформе.

4. «Аква» - упражнения в воде;

5. Джасесайз - танцы в ритмах джаза.

6. «Калланетика» - комплекс упражнений, выполняемый в статическом режиме. Треть упражнений составляют упражнения на вытяжение позвоночника, растяжение мышц спины и задней поверхности ног.

При всем существующем разнообразии в последние годы появились фитнесновинки, такие как:

1. Памп - силовая аэробика со штангой весом от 2 до 18 килограммов. Упражнения выполняются без остановок в течение 45 минут под ритмичную музыку. Танцевальные элементы из нее исключены. Тренировочный эффект аэробики со штангой, без сомнения, очень велик, однако рекомендуется она только физически подготовленным людям.

2. Спининг или сайкл рибок - этот модный стиль появился с легкой руки американского велосипедиста Джонни Голдбера и представляет собой динамическую тренировку на велосипедах, совмещенную с просмотром видеофильма. Всего за 45 минут езды под бодрящую музыку можно проехать по разным странам, по возвышенностям, равнинам и пустыням и при этом изрядно попотеть, сбросить лишний вес, укрепить мышцы рук и ног, ягодиц и живота и получить массу удовольствий.

3. Слайд - силовой вид аэробики. Занимающиеся одевают ступни-подвижки на специальную гладкую дорожку длиной 183 см и 
шириной 61 см и, скользя на ней, выполняют упражнения, напоминающие движения конькобежца. Слайд-аэробика укрепляет сердечно-сосудистую и дыхательную системы, мышцы и суставы.

4. Резист-бол это забавный вид аэробики с использованием специальных разноцветных надувных мячей разной величины (некоторые из них достигают в диаметре 1 метра). Резист-бол помогает скорректировать фигуру, развивает координацию движения и гибкость, способствует исправлению осанки и укреплению сердечно-сосудистой и дыхательной систем.

5. Бокс-аэробика и карате-аэробика базируются на основных элементах соответствующих видов спорта. Эти виды созданы в основном для тех, кто, доведя фигуру до совершенства, хочет поддерживать форму с помощью новых стилей.

6. Йога-аэробика. Сочетает статические и динамические асаны, дыхательные упражнения, упражнения и концентрацию внимания на работе мышц и деятельности внутренних органов.

Фристайл. В переводе с английского «фристайл« означает «свободный стиль», он представляет собой горнолыжное троеборье, в которое входят: могул - скоростной спуск на горных лыжах по бугристой трассе; лыжный балет - спуск на лыжах по пологому склону с выполнением под музыку элегантных скользящих шагов, прыжков, поворотов и вращений; лыжная акробатика - прыжки на лыжах со специального трамплина с выполнением в воздухе элементов акробатики (двойное сальто, сальто с пируэтом и др.) и с приземлением на лыжи без потери равновесия. Фристайл получил свое развитие более чем в пятидесяти странах мира. По фристайлу проводятся чемпионаты Европы и мира, а также соревнования на Кубок мира. За последние годы фристайл получает все более широкое распространение в нашей стране. 
Шафл-борд. Оборудование для игры состоит из восьми деревянных дисков толщиной 25 мм и диаметром 150 Мм. Четыре диска окрашены в красный цвет, четыре - в синий. Игра проводится клюшками, по форме напоминающими лопату шириной не более диаметра диска, длиной до 1 м 90 см, ее ручка может быть из дерева или из тонкой дюралюминиевой трубки. Играют на продолговатой площадке размером 16х2 м. Играют один на один или двое надвое. Цель игры - послать клюшкой диски из своей базы в треугольник-мишень на противоположном конце площадки. Игра состоит из трех раундов, каждый из них делится на два полураунда. В первом полураунде обе команды начинают игру из 1-го города, во втором - из 2-го. Результаты двух полураундов суммируются. Выигравший два раунда из трех выигрывает всю игру. Шафл-борд развивает глазомер и способность определять расстояние до различных предметов. Эта игра только получает свое развитие.

Шейпинг - эффективное средство для укрепления здоровья и совершенствования телосложения людей различного возраста. Он объединяет в себе упражнения аэробики и атлетической гимнастики. Имеет большую популярность среди женщин. При занятиях шейпингом интенсивность физической нагрузки дозируется строго индивидуально. Для шейпинга характерен строгий врачебный контроль за состоянием физического развития и функциональной подготовленностью с помощью современной электронной аппаратуры.

Шорт-трек (короткая дорожка) - бег на коньках в хоккейной коробке на различные дистанции: 4 круга, 500 м, 1500 м и др. Старт общий, стартуют одновременно не более восьми спортсменов. Победителем объявляется тот, кто первым пересек финишную линию. Бег выполняется на специальных беговых коньках с укороченным лезвием.

Альпинизм - вид спорта, специфическая основа которого восхождение на вершину горы, преодоление крутых скальных, ледовых и 
снежных склонов, вынужденные ночлеги в условиях, когда физические, нервно-энергетические затраты не восстанавливаются днями, неделями. Горовосхождение требует высоких морально-волевых качеств, достаточного уровня физической подготовленности и определенных навыков скалолазания.

2. Определите индивидуальные особенности для обоснования выбора вида физических упражнений

Для выявления индивидуальных особенностей учащихся с целью обоснования индивидуального выбора физических упражнений или вида спорта использовались тесты (по материалам Ю.И. Евсеева, 2004), составленные по рекомендации Эрика Лоро.

Тестирование

I. Дыхание

1. Курите ли вы: нет - 5 очков; да, 5 сигарет в день - 4; да, 10 - 3; более 20 в день - 0 .

2. У Вас появляется одышка, когда вы быстро ходите: через несколько метров - 1 очко; через несколько сотен метров - 3; через несколько километров - 4.

3. Как Вы дышите после того, как шагом поднялись на второй этаж: достаточно равномерно 2 очка; задыхаетесь - 1.

4. Когда вы занимаетесь физкультурой, что вас заставляет остановиться, передохнуть: затрудняется дыхание - 2 очка; устают мышцы - 4.

5. Сколько времени вы можете задерживать дыхание под водой не дыша: 30 секунд — 3 очка; 45 секунд — 4; более минуты — 5. Умеете ли восстанавливать дыхание после интенсивных физических упражнений, нагрузок: нет - 0 очков; иногда - 2; часто - 3 очка.

Результаты: 
От 23 до 16 очков. Вы умеете владеть своим дыханием. Оно отлично приспособлено к вашей трудовой и спортивной деятельности. Вы можете заниматься любым видом спорта: баскетболом, волейболом, теннисом, плаванием, серфингом, водными лыжами, подводным плаванием... Выбор за вами!

От 15 до 6 очков. Вам нужно развивать, тренировать свое дыхание. Выполняйте ежедневно прыжки со скакалкой в течение 10 минут. Очень важно научиться правильно дышать, делать полный вдох и выдох. Рекомендуем умеренные физические нагрузки, но при этом прилагайте больше старания, делайте эти упражнения тщательно, регулярно. Советуем вам заняться ездой на велосипеде, кроссовым бегом, плаванием.

5 и менее очков. Вы не умеете правильно дышать, И прежде чем займетесь каким-то видом спорта, вам придется этому научиться: «складировать» воздух, подготавливать свои легкие. Больше ходите пешком. Каждые утро и вечер выполняйте следующее упражнение: в положении лежа глубоко вдыхайте и полностью выдыхайте воздух, напрягая пресс. Проделайте эти упражнения 20 раз. За счет этих упражнений для развития дыхания Вы повысите продуктивность, «производительность» своих легких и сможете совершать длительные пешие походы по пересеченной местности. Такие походы на свежем воздухе успокаивают нервную систему, развивают, улучшают работу легких.

II. Аэробные способности

1. Ходите ли вы пешком: никогда 0 очков; иногда - 1 ; регулярно по 1 км в день - 2; от 1 до 3 км в день - 3 ; свыше 3 км - 4 очка

2. Занимаетесь ли вы каким-либо видом спорта: ездой на велосипеде, плаванием или бегом: никогда - 0 очков; иногда - 2 ; регулярно - 4 . 
3. Сколько времени вы занимаетесь каким-либо из видов спорта, которые мы назвали: полчаса - 2 очка; от получаса до 1 часа 3 ; свыше часа -4.

4. Можете ли вы разговаривать, когда быстро ходите, бежите или едете на велосипеде: да -2 очка; нет -0 очков.

5. Каково примерно расстояние, которое вы можете преодолеть за 12 минут ходьбы, бега трусцой: более 2,6 км - 5 очков; от 2,6 до 2 км - 4; $1,7-1,5$ км - 3 ; менее 1,5 км 2 очка.

Результаты:

От 19 до 12 очков. У вас энергичная активная натура. Вы не только можете заниматься любым видом спорта, у вас есть основания подумать над тем, не заняться ли спортом всерьез. Пробегайте в вашем обычном темпе несколько километров, после этого делайте ускорение на 100-200 м. Таким образом, вы будете развивать специальную выносливость. Вам полезно было бы ездить на учебу и в магазины на велосипеде. Летом на реке, на море бегайте по песку, плавайте как можно дальше. Если же вы отдыхаете в горах, попытайтесь преодолеть на велосипеде трудные участки и забраться на крутые склоны

От 11 до 6 очков. Вы можете заниматься некоторыми видами спорта, но прежде вам нужно развить свои аэробные способности с помощью таких видов спорта, как вело - спорт, плавание, бег... Будьте терпеливы и настойчивы в этих занятиях. Когда бежите или едете на велосипеде, старайтесь разговаривать с товарищами, дышите глубоко и равномерно, старайтесь не задыхаться. Не забывайте, что настоящие физические нагрузки мы получаем только после 20 минут активной физической нагрузки.

От 5 и менее очков. Разработайте свою программу, в которой предусмотрите ежедневную ходьбу от 2 до 5 км, чередуя ее с бегом по пересеченной местности. Включите в ежедневные физические нагрузки 
езду на велосипеде или плавание. Причем постоянно увеличивайте продолжительность занятий и расстояние. Но если такие интенсивные нагрузки превышают ваши возможности, то сначала ограничьтесь упражнениями со скакалкой или откажитесь от лифта и поднимайтесь по лестнице пешком. Через некоторое время попытайтесь снова приступить к занятиям велоспортом, плаванию или бегу. Эффект не замедлит сказаться.

II. Гибкость тела

1. И.п. ноги вместе, медленно наклоняйтесь к полу: достаете ли вы пол ладонями - 4 очка; пальцами - 3; не касаетесь пола - 0.

2. Ноги врозь. Наклонитесь влево и вправо, не двигая тазом: вы касаетесь икр ног - 4 очка; достаете до колена - 3; не дотянетесь до колена 0.

3. Лежа на спине, заведите ноги за голову: прямой ногой коснетесь пола - 4 очка; коснетесь слегка согнутой ногой -3 ; согнутой -2 ; не коснетесь - 0 .

Результаты:

От 12 до 8 очков - вас хорошая гибкость. Для поддержания формы рекомендуем вам заниматься гимнастикой, спортивными танцами, плаванием.

От 7 до 4 очков. Ваша гибкость недостаточна. Необходимы разнообразные занятия «силовой» спорт (баскетбол, волейбол, гандбол и др.), с более «мягкими», например, теннисом, гимнастикой, спортивными танцами.

От 3 до 0 очков. Уровень развития Вашей гибкости низкий. Необходимы спортивные занятия, которые развивают гибкость и мускулатуру, - гимнастика, спортивные танцы, йога, плавание. Эти виды спорта и упражнения на развитие чувства равновесия помогут вам. Но не перенапрягайтесь, исходите из ваших возможностей. Только терпение и продолжительные тренировки могут развить гибкость. 
III. Прыгучесть

1. Ноги вместе, сделайте мах руками и сделайте прыжок с места вперед. На сколько вы прыгнете: 120 см -2 очка; 160 см -3; 180 см - 4; 200 см и более -5.

2. Поставьте ноги вместе, встаньте у стены и с поднятой над головой рукой мелом отмерьте на стене высоту. На сколько выше этой отметки вы прыгнули: на 25 см - 1 очко; на 25-30 см - 2. на 30- 40 см - 3; на 40-50 см - 4; более 50 см -5 .

Результаты:

От 10 до 6 очков. Вы активны, энергичны. Рекомендуем вам любые виды спорта на открытой площадке. Вы можете заниматься волейболом, баскетболом, плаванием, легкой атлетикой. Но не переутомляйтесь!

5 и менее очков. К сожалению, ваши успехи в этой области скромны. Займитесь сначала со скакалкой, больше прыгайте, по крайней мере, 5 минут в день. Когда вы ходите пешком или бежите, то прыгайте через препятствия, которые встретите на своем пути - кусты, поваленные деревья, канавки, садовые скамейки, невысокие ограды. Прыгайте, пытаясь схватить листья деревьев (конечно, не срывая их!). Играйте в волейбол или баскетбол. И результаты не замедлят сказаться.

IV. Ваши мышцы

1. Болят ли у вас мышцы после физических нагрузок:всегда - 2 очка; никогда - 4 .

2. Испытываете ли вы боль в ногах, когда ходите на лыжах, ездите на велосипеде: всегда -2 очка; иногда -3 никогда -4 . Ноют ли у вас ноги, когда вы пешком преодолели несколько этажей: иногда - 2 очка; никогда - 3.

3. Бывают ли у вас мышечные спазмы: часто - 1; редко или никогда -2 . 
4. Чувствуете ли вы боль в руках и плечах, когда плаваете или ездите на велосипеде: часто - 2 очка; иногда -3 ; никогда - 4. Можете ли вы без затруднений делать что-то с высоко поднятыми руками: да- 3 очка; нет -0 .

5. Попробуйте присесть на одной ноге, другую, держа прямо, не помогая при этом руками: вы успешно выполнили это упражнение - 4 очка; вы выполнили его, но потеряли равновесие - 3; выполнили, помогая при этом руками -2 ; не смогли выполнить -0 .

6. Чувствуете ли Вы боль в спине спустя $2-3$ часа после физической нагрузки: всегда -1 очко; иногда 2 ; никогда -3 .

Результаты:

От 27 до 20 очков. Ваши мышцы в хорошем состоянии. Занимайтесь тем видом спорта, который вас больше увлекает, но не забывайте совершать пешие переходы по пересеченной местности, походы в горы. Это увеличит силу мышц.

От 19 до 10 очков. Вам нужно еще больше развивать свои мышцы. Выполняете упражнения с гирями и гантелями. Играйте в волейбол или баскетбол.

9 и менее очков. Ваша мышечная система развита слабо, для занятий спортом используйте каникулы и хотя бы два раза в неделю делайте по $30-45$ минут гимнастические упражнения. Но не перенапрягайтесь! Избегайте появления физической изнуренности и спазма мышц. После каникул, продолжайте занятия еще более интенсивно, но не забывайте давать себе минуты отдыха. И побольше плавайте - это будет массажем для усталых мышц и успокоит вас.

Методика для выявления стремления к путешествиям, занятиям туризмом.

1. Что вы делаете, если вам предстоит отправиться в путь: 

а) собираетесь в дорогу;
б) мечтаете о путешествии;
в) испытываете какой-то смутный страх, неуверенность.

2. Что бы вы сделали, если бы вам предстояло отправиться в Японию;

а) узнали бы, есть ли опасность землетрясения;

б) целый месяц питались бы традиционной японской пищей;

в) купили бы разговорник и учили слова.

3. Аделаида - это:

а) женское имя;

б) город в Австралии;

в) название музыкального произведения.

4. Вы приехали в аэропорт, а вылет отложили до следующего дня. Что вы будете делать:

а) останетесь в здании аэропорта;

б) возвратитесь домой;

в) попытаетесь улететь другим рейсом.

5. (Попробуйте ответить на этот несколько шутливый вопрос.) Когда вы путешествуете, какое обычно у вас бывает выражение лица:

а) спокойное, даже несколько отрешенное;

б) величественное, торжественное (как у Марко Поло);

в) простодушное, наивно-любопытное (как у Красной Шапочки).

6. Один ваш приятель рассказывает, что был за рубежом и путешествовал вместе с... катамараном. Вы думаете:

а) это какой-то корабль, да и его название звучит так хорошо;

б) как бы вы радовались, если бы были вместе с ним;

в) наверняка он купил какую-то экзотическую птицу.

7. Вы предпочитаете путешествовать:

a) самолетом; 
б) на машине;

в) на чем угодно, лишь бы добраться до места.

8. Если бы вы полетели через океан и вас предупредили о сложности адаптации к смене часовых поясов, то:

a) вы бы сохранили спокойствие;

б) более подробно расспросили бы, о чем идет речь;

в) считали бы, что все будет хорошо, если только вы как следует выспитесь.

9. Представьте, что ваш друг (подруга) ухаживает за почтовыми голубями на балконе:

a) вы постоянно стали бы заботиться об их кормлении;

б) купили бы книги по уходу за голубями;

в) отчаялись бы от того, что они никак не улетят навсегда, а всякий раз возвращаются.

10. Вы попали в незнакомый город, у вас украли суму. Вы расстроены, потому что:

а) остались без денег;

б) не запомнили адрес своей гостиницы;

в) вместе с сумкой потеряли карту города.

11. Каково ваше рекордное время для сбора чемодана:

a) 20 минут для дальнего путешествия;

б) 3 часа, чтобы провести месяц на побережье;

в) вы неделю собираетесь, чтобы уехать на выходные дни.

12. По лотерее вы выиграли средиземноморский круиз:

а) решаете использовать путешествие для работы;

б) покупаете летние костюмы;

в) хотите заменить выигрыш на деньги.

13. Вы считаете, что путешествие на байдарке с друзьями:

а) испортит и самые хорошие приятельские отношения; 
б) только укрепит дружбу;

в) такой проблемы у вас нет, вы путешествуете в одиночку.

14. Если бы вы решили поехать на Огненную Землю, то потому что:

а) там холодно;

б) там жарко;

в) хотели бы познакомиться с коренными жителями.

Теперь по таблице подсчитайте результаты.

Оценка результатов тестирования

\begin{tabular}{|l|l|l|l|l|l|l|l|l|l|l|l|l|l|l|}
\hline $\begin{array}{l}\text { Вариант } \\
\text { ответа }\end{array}$ & \multicolumn{10}{|l|}{ Номер вопроса } \\
\hline & 1 & 2 & 3 & 4 & 5 & 6 & 7 & 8 & 9 & 10 & 11 & 12 & 13 & 14 \\
\hline а & 3 & 1 & 1 & 2 & 0 & 3 & 1 & 0 & 2 & 2 & 3 & 3 & 1 & 2 \\
\hline 6 & 2 & 2 & 3 & 1 & 3 & 2 & 1 & 1 & 2 & 1 & 2 & 1 & 2 & 0 \\
\hline в & 0 & 3 & 0 & 3 & 1 & 0 & 3 & 3 & 1 & 3 & 0 & 0 & 3 & 3 \\
\hline
\end{tabular}

Менее 9 очков. Вы - домосед. Это, разумеется, не страшно. Вы любите, чтобы все было в порядке, шло своим чередом. Вам неприятна даже мысль о подготовке к дороге, трудностях пути, неустроенности быта, опасностях, которые вас подстерегают. Так что путешествие едва ли доставит вам удовольствие... Весь вопрос в том, не проявляется ли в этом ваша апатия, склонность к замкнутому образу жизни. А это далеко не безобидно. В конце концов, вы можете стать рабом своих привычек. Ваш характер спокоен, вы любите стабильность, принимаете хорошо продуманные решения. Логично, что вы предпочитаете проводить летний 
отдых в постоянном месте - на турбазе или в санатории, а не путешествовать по незнакомым местам.

От 9 до 14 очков. Для вас путешествие - это отдых. Таким образом, вы «убегаете», от стресса, от необходимости расписывать жизнь по минутам, вечно спешить. Но в то же время вы не сторонник дикого, неорганизованного отдыха, вы считаете, что он должен быть хорошо продуман. У вас нет страсти открывать новые миры. Вас просто привлекает возможность сменить обстановку. Но у вас не слишком развита любознательность. Во время путешествия для вас нежелательны какие-то отклонения от намеченной программы, вы хотели бы избежать неожиданностей, проблем. Вы знаете, зачем вы путешествуете, но не знаете, чего хотите на самом деле. Для вас предпочтительнее не открытия, неожиданности путешествия, а продуманные, заранее запрограммированные экскурсии. Вы организованный (или цивилизованный) турист.

Более 15 очков. Есть ли у вас страсть к путешествиям? Излишний вопрос это у вас в крови. У Вас не только есть страсть к путешествиям, вы усвоили их истинный смысл; путешествовать открывать новые места прекрасный способ познать и самого себя. Ваша скитальческая натура рвется в путешествия, стремиться убежать от комфорта, напряженной современной жизни. Вы любите трудности. Не переносите, когда вас связывают какими-то протоколами, программой. Вы всячески уклоняетесь от них, но если все-таки вынуждены придерживаться программы, то вас не покидает желание... сбежать. Вы испытываете удовольствие от того, что сами планируете свой маршрут, готовитесь к нему и как только отправляетесь в дорогу, полностью вживаетесь в обстановку, Пытаетесь узнать как можно больше. Вы можете стать индейцем с Амазонки, или охотится с племенем масаев в Кении, везде вы будете чувствовать себя как в раю. 
3. На основании проведенного исследования опредеоить наиболее приемлемые системы упражнений или вид спорта для индивидуальных занятий.

4. Пользуясь методической литературой и с учетом индивидуальных особенностей разработать методику овладения одним из рассмотренных видов физических упражнений (задание можно выполнить групповым методом по 2-3 человека).

\section{Литература:}

1. Бальсевич, В.К. Физическая культура для всех и для каждого [Текст] / В.К. Бальсевич. - М.: Физкультура и спорт, 1988. - С.25.

2. Белов, В.И. Йога для всех [Текст] / В.И. Белов. - М.: КСП. - 1997. $-160 \mathrm{c}$.

3. Бутин, И.М. Лыжный спорт [Текст]: Учеб. пособие для студ. высш. пед. учеб. Заведений / И.М. Бутин. - М.: Академия. - 2000. - 368 с.

4. Велитченко, В.К. Как научиться плавать [Текст] / В.К. Величенко. - М.: Терра-Спорт, 2000. - 96 с.

5. Вяткин, Л.А. Туризм и спортивное ориентирование [Текст]: учеб. пособ.: рек УМО / Л.АВяткин и др. - М.: Академия, 2004. - 208 с.

6. Гимнастика [Текст]: Учеб. пособ. для студ. высш. пед. учеб. заведений / Под ред. М.Л. Журавина, Н.К. Меньшикова. - М.: Академия. 2005. -445 c.

7. Евсеев, Ю.И. Физическая культура [Текст]: Учеб. пособие. / ЮИ. Евсеев. - Ростов - н/Д: Феникс, 2004. - 384 с.

8. Жилкин, А.В. Легкая атлетика [Текст]: учеб пособ. / А.И. Жилкин, В.С. Кузьмин, Е.В. Сидорчук. - М.: Академия, 2005. - 464 с.

9. Лисицкая, Т.В. Ритмическая гимнастика [Текст] / Т.В. Лисицкая. M., 1986. 
10. Нестерковский, Д.И. Баскетбол: теория и методика обучения [Текст]: учеб. пособие / Д.И. Нестерковский. - М.: Академия, 2006. - 336 с. 11. Укран, М.Л., Смолевский, В.М., Шлемин, А.М. Атлетическая гимнастика [Текст] / М.Л. Укран, В.М. Смолевский, А.М. Шлемин. - М.: Физкультура и спорт. - 1965. - 72 с.

Практическая работа № 2. Самоконтроль на занятиях физическими упражнениями

\section{Задачи:}

1. Овладеть методиками определения индивидуального функционального состояния, уровня физической подготовленности.

2. Овладеть технологией составления дневника самоконтроля.

Задание. Составить типовую страницу дневника самоконтроля.

Технология выполнения работы.

1. Ознакомьтесь с теоретическим материалом по теме.

Под самоконтролем подразумевается самостоятельное наблюдение в своей привычной жизни за состоянием своего здоровья, физическим развитием, функциональным состоянием организма, физической подготовленностью и их изменениями под влиянием занятий физическими упражнениями. Самоконтроль является существенным дополнением к физиологическому и педагогическому контролю, но ни в коем случае их не заменяет [8]. Самоконтроль может носить физиологический либо педагогический характер, а может включать в себя и то, и другое. Данные самоконтроля оказывают большую помощь преподавателю в регулировании физической нагрузки, а физиологу/врачу своевременно сигнализируют об отклонениях в функциональном состоянии. 
К субъективным показателям самоконтроля относятся: самочувствие, настроение, наличие или отсутствие болевых или других неприятных ощущений, сон, аппетит, отношение к занятиям и др.

К объективным показателям самоконтроля относятся частота пульса, вес, сила мышц, жизненная емкость легких, результаты учебы и др.

Наиболее удобная форма самоконтроля - это ведение дневника, содержание и построение которого могут быть различными. Он включает как субъективные, так и объективные показатели самоконтроля. При занятиях физической культурой по учебной

программе, a также при самостоятельных занятиях можно ограничиться такими показателями, как самочувствие, сон, аппетит, болевые ощущения, пульс, вес, тренировочные нагрузки, нарушение режима, спортивные или учебные результаты.

Самочувствие является субъективной оценкой состояния организма и бывает хорошим, удовлетворительным и плохим. При плохом самочувствии фиксируется характер необычных ощущений.

Сон. В дневнике отмечаются продолжительность и глубина сна, его нарушения (трудное засыпание, беспокойный сон, бессонница, недосыпание и др.).

Аппетит бывает хорошим, пониженным и чрезмерным. Различные отклонения в состоянии здоровья быстро отражаются на аппетите, поэтому его существенные изменения, как правило, являются результатом переутомления, заболевания или несоблюдения правил культуры питания.

Пульс - важный показатель состояния организма. Обычно на учебных занятиях по физической культуре частота пульса при средней нагрузке достигает 130-150 ударов в минуту. На спортивных тренировках, при значительных физических нагрузках частота пульса доходит до 180-200 ударов в минуту и более. После большой физической нагрузки пульс приходит к исходным величинам через 20-30, иногда через 40-50 
минут. Если в указанное время после учебно-тренировочного занятия пульс не возвращается к исходной величине, это свидетельствует о наступлении сильного утомления в связи с недостаточной физической подготовленностью или наличием каких-то отклонений в состоянии организма.

Для оценки деятельности сердечно-сосудистой и дыхательной систем можно применять различные функциональные пробы, а их результаты записывать в дневник самоконтроля.

Вес тела рекомендуется определять утром натощак, в одном и том же костюме. В первом периоде тренировки вес обычно снижается, затем стабилизируется и в дальнейшем за счет прироста мышечной массы несколько увеличивается. При резком снижении веса следует обратиться к врачу.

Тренировочные нагрузки основной части занятия и нарушение режима вместе с другими показателями дают возможность объяснить различные отклонения в состоянии организма. Болевые ощущения: в мышцах, голове, в правом или левом боку и в области сердца могут наступать при нарушениях режима дня при общем утомлении организма, формировании тренировочных нагрузок и т. п. Боли в мышцах на начальном этапе занятий — явление закономерное. Во всех случаях продолжительных болевых ощущений следует обратиться к врачу.

Наблюдение за спортивными результатами является важным пунктом самоконтроля, которое показывает правильность применения средств и методов занятий тренировок и может выявить дополнительные резервы для роста физической подготовленности.

Особую роль играет самоконтроль для студентов, имеющих ослабленное здоровье и занимающихся в специальном учебном отделении. Самоконтроль в значительной мере помогает их рациональному физическому воспитанию, способствует эффективному использованию 
средств физической культуры для укрепления их здоровья, борьбы с имеющимися отклонениями и заболеваниями, повышения физической и общей работоспособности.

Самоконтроль помогает занимающемуся физическими упражнениями следить за собственным состоянием, прививает грамотное и осмысленное отношение к занятиям физической культурой.

2. Измерьте свой пульс покоя с перечислением всех этапов.

Пульс (частота сердечных сокращений) и его изменения важнейший показатель функционального состояния сердечно-сосудистой системы.

Измерение:

1) необходимо принимает положение сидя;

2) пальпируются (прощупываются) височная, сонная, лучевая артерия или сердечный толчок по 15-секундным отрезкам 2-3 раза подряд, чтобы получить достоверные цифры;

3) делается перерасчет на 1 минуту (число ударов в минуту).

Оценка: ЧСС в покое в среднем у мужчин 55-70 ударов в минуту, у женщин 60-75 ударов в минуту. При частоте свыше этих цифр пульс считается учащенным (тахикардия), при меньшей частоте - замедленным (брадикардия).

3. Рассчитайте индекс массы тела по своим показателям роста/веса.

Необходимо встать на ростомер для измерения роста, затем на механические весы для измерения веса.

Индекс массы тела (по ВОз) рассчитывается по формуле:

ИМТ (кг/м2) = вес (кг) / .рост (м)2

Показатели индекса массы тела интерпретируются следующим образом: 
3 балла — «норма - 18,5-24,99 кг/м2 (масса тела в норме);

2 балла — «удовлетворительно» - 16,5-18,49 кг/м2 (недостаточная масса тела) и 30-34,99 кг/м2 (ожирение первой степени);

1 балл - «неудовлетворительно» - менее 16 кг/м2 (выраженный дефицит массы) и более 35 кг/м2 (ожирение второй или третьей степени).

4. Вычислите свой адаптационный потенциал по формуле, предложенной Р. М. Баевским (по своим измеренным показателям).

Адаптационный потенциал (далее - АП), предложенный в свое время Баевским, характеризующий напряженность всех систем организма и адаптационные резервы организма [7]. АП - комплексный показатель, построенный на основе регрессивных взаимоотношений - частоты сердечных сокращений (ЧСС), систолического (САД) и диастолическего (ДАД) артериального давления, возраста (В), массы тела (МТ) и роста (Р). Все эти показатели, по многочисленным данным, играют существенную роль в становлении, закреплении адаптации (А) организма к многочисленным воздействиям внешней среды, а уровни их регрессионных отношений могут характеризовать уровень (А) в целом, особенно при оценке и динамическом наблюдении в антропоэкологических системах. АП (у. е.) высчитывается по формуле Баевского (1987 г.):

$$
\begin{aligned}
& \text { АП }=(0,011 \text { ЧСС + 0,014 АДсист + 0,008 АДдиаст ++ 0,014 возраст } \\
& +0,009 \text { масса }-0,009 \text { рост })-0,27
\end{aligned}
$$

где АДсист - систолическое артериальное давление в фоне, АДдиаст - диастолическое артериальное давление;

4 балла - 2,10 - удовлетворительная Адаптация (А) (характеризует достаточные функциональные возможности системы: кровообращения);

3 балла - 2,11-3,20 - функциональное напряжение (A) механизмов; 
2 балла - 3,21-4,30 - неудовлетворительная (А) (характеризует снижение функциональных возможностей системы кровообращения с недостаточно приспособляемой реакцией к нагрузкам);

1 балл - более 4,30 - срыв (А) (характеризует резкое снижение функциональных возможностей системы кровообращения с явлением срыва (А) механизмов целостного организма).

Показатель АП достоверно характеризует уровень (А) целостного организма, а его основные составляющие являются индикаторами здоровья.

5. Заполните первую графу страницы дневника самоконтроля. Результат оформить в виде таблицы.

Примерная форма дневника самоконтроля

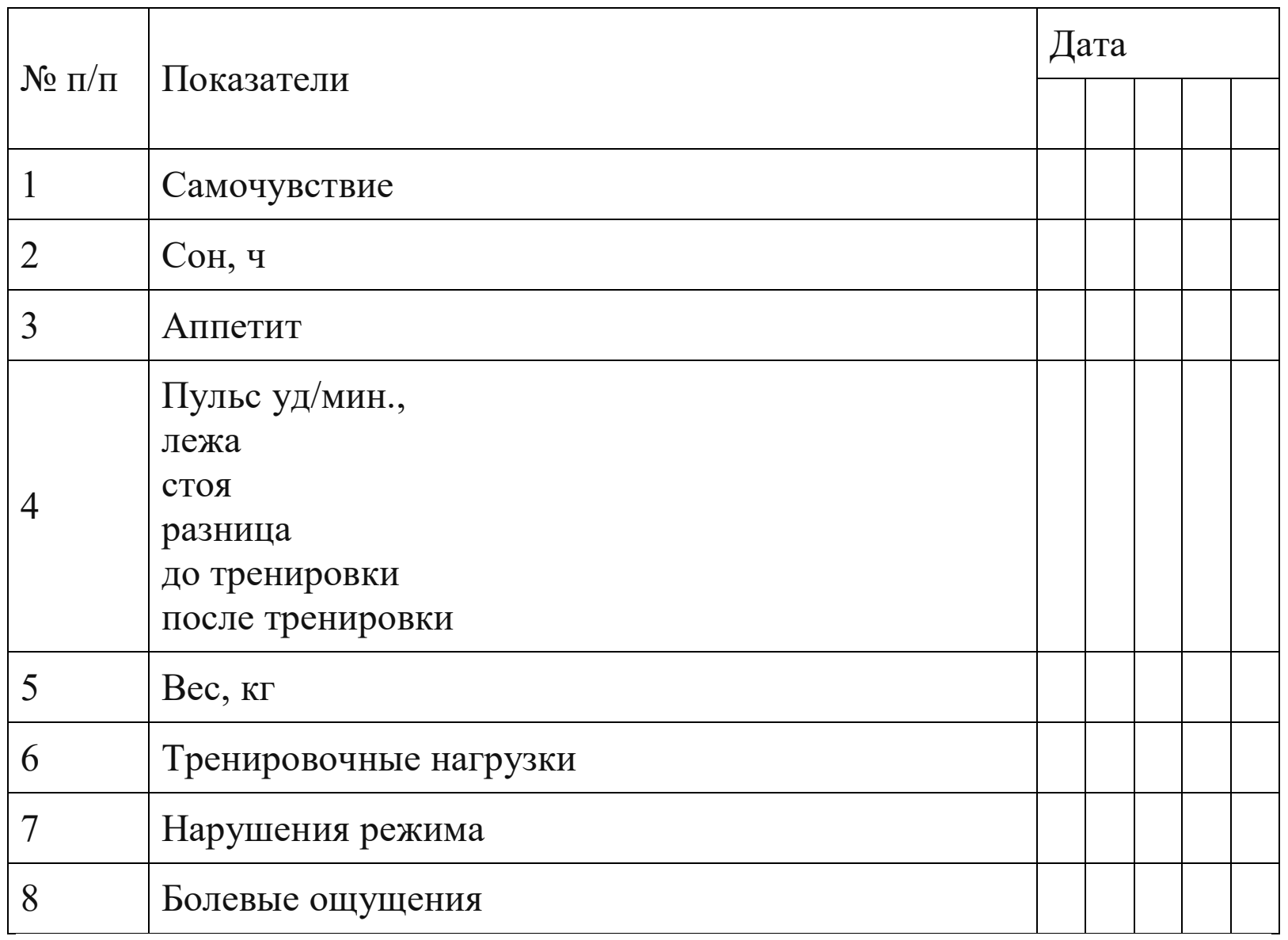




\section{Литература.}

1. Анохин, П.К. Узловые вопросы теории функциональной системы [Текст] / П.К. Анохин. - М.: Наука, 1980.

2. Бишаева, А.А. Профессионально-оздоровительная физическая культура студента [Текст]: Учеб. Пособие / А.А. Бишаева. - М.: Кнорус, 2013.

3. Баевский, P.М., Берсенева, А.П. Оценка адаптационных возможностей организма и риск развития заболеваний [Текст] / P.М. Баевский, А.П. Берсенева. - М.: Медицина, 1997. - С. 10-42.

4. Готовцев, П.И., Дубровский, В.И. Самоконтроль при занятиях физической культурой и спортом [Текст] / П.И. Готовцев, В.И. Дубровский. - М.: физкультура и спорт, 1984.

5. Половников, П.В. Организация занятий студентов по дисциплине «Физическая культура» [Текст]: Учеб. пособие / П.В. Половников. - СПб.: СПбГТУ, 1996.

6. Поляков, С.Д., Хрущев, С.В., Корнева, И.Т. Мониторинг и коррекция физического здоровья школьников [Текст]: Метод. пособие / С.Д. Поляков, С.В. Хрущев, И.Т. Корнева. - М.: Айрис-пресс, 2006.

Практическая работа № 3. Индивидуальная программа оздоровительной тренировки

Задачи:

1. Обобщить и систематизировать теоретические сведения по данному вопросу.

2. Научиться выбирать средства, планировать место, время индивидуальной физкультурно-оздоровительной деятельности.

Задание. Составить индивидуальную программу оздоровительной тренировки

Технология выполнения работы 
1. Обобщить и систематизировать теоретические сведения по данному вопросу.

Составляя индивидуальную программу занятий спортом, студенту важно учитывать свое здоровье, уровень физической подготовленности, свои возрастно-половые особенности развития, материально-технические условия занятий.

Для планирования индивидуальной физической активности следует уметь подбирать для себя наиболее эффективные и полезные виды и формы физических упражнений.

Намеченный результат индивидуальных занятий физическими упражнениями достигается за счет соблюдения принципов сознательности и активности, систематичности, постепенности, индивидуализации нагрузок и комплексности [4].

Систематичность физических нагрузок обеспечивает переход срочных приспособительных реакций в долговременную адаптацию, в основе которой лежит усиленный адаптивный синтез белка, ведущий к увеличению мощности функционирующих клеточных структур. Если же через определенный период двигательная нагрузка не повторяется, усиленный синтез белка выключается и заменяется расщеплением тех белков, которые интенсивно синтезировались, т.е. возвращается в исходное состояние. Устраняются сверхвосстановленные запасы источников энергии. Принцип постепенности повышения физических нагрузок предполагает строго индивидуальный подход к их повышению. Для этого важен правильный выбор упражнений по их направленности, объему и мощности воздействия. Данный принцип реализуется путем усложнения движений (повышения их координационной сложности и вариантности) и расширения их состава. Принцип индивидуализации предполагает соответствие физических нагрузок возрасту, полу, состоянию здоровья занимающегося. Принцип комплексности направлен на развитие 
всех основных двигательных качеств. Первостепенна общая выносливость, существенны сила, силовая выносливость, важны и необходимы скоростно-силовые качества, ловкость, гибкость.

Основные характеристики физической работы.

По специфике воздействия упражнения бывают аэробными и анаэробными [3]. Аэробное упражнение - вид физического упражнения относительно низкой интенсивности, при которой кислород служит основным источником энергии для поддержания мышечной работы. Под аэробной нагрузкой понимается систематическое выполнение физических упражнений, которые охватывают работой большую группу мышц (около 2/3 мышечной массы тела) и являются продолжительными (15-40 мин без перерыва и более), но самое главное - обеспечиваются энергией за счет аэробных процессов. К числу аэробных упражнений относят ходьбу, бег, плавание, коньки, подъем по ступенькам, греблю, катание на скейте, роликовых коньках, танцы, баскетбол, теннис. Преимущества регулярной аэробной тренировки: укрепление дыхательных мышц, сердечной и скелетных мышц, повышение их эффективности, снижение пульса в покое; улучшение циркуляции крови, снижение давления; рост числа красных кровяных телец, доставляющих кислород в ткани; улучшение психического состояния, снижение стресса, риска депрессии и диабета. Рекомендуют не менее 20 минут аэробных занятий три раза в неделю. Аэробные упражнения развивают сердечно-сосудистую систему, что отражается на развитии выносливости.

Для развития силы необходимо совмещать оба типа тренировок. При анаэробном упражнении энергия вырабатывается за счет быстрого химического распада «топливных» веществ в мышцах без участия кислорода. Этот способ срабатывает мгновенно, но быстро истощает запасы готового «топлива» (0,5-1,5 мин), после чего запускается механизм 
аэробной выработки энергии. Характерные примеры анаэробной деятельности - силовая подготовка и спринтерский бег.

Главные характеристики мышечной работы - eе объем и интенсивность [9]. Объем нагрузки может быть выражен количеством упражнений или занятий, метражом пробегаемых расстояний, суммарной массой поднятых отягощений и т.д. Интенсивность нагрузки означает напряженность тренировочной работы и степень ее концентрации во времени. Объем и интенсивность нагрузок неразделимы и вместе с тем противоположны. Одновременно их можно увеличивать до определенного предела. Более целесообразно на начальном этапе тренировки увеличение нагрузки за счет ее объема, а в последующем, по мере постепенного повышения возможностей организма, - в основном за счет интенсивности.

Обычно интенсивность работы выражается в процентах от максимального потребления кислорода (МПК). На основании большого количества исследований рекомендуется интенсивность аэробных упражнений на уровне 50-85\% МПК или 60-90\% пульсового резерва, а продолжительность - от 15 до 60 мин. Нужно знать, что лучшие результаты в тренировке достигаются при соответствии нагрузок функциональным возможностям людей.

2. Используя план составьте индивидуальную программу занятий.

1 Определить цель и задачи индивидуальной программы.

2 Определить приемы, средства, методы тренировки в индивидуальной программе.

3 Определить место проведения индивидуального занятия.

4 Определить число занятий в день, неделю, месяц и период занятий по программе.

5 Определить физическую подготовленность на данный момент. 
6 Выбрать средства и методы самоконтроля самостоятельных занятий видом спорта.

7 Определить дозировку нагрузки на занятии.

8 Определить последовательность выполнения индивидуальной программы.

9 Установить контрольные точки для корректировки индивидуальной программы.

10 Оформить план-график индивидуальной программы.

\section{Литература}

1. Гимнастика [Текст]: Учеб. пособ. для студ. высш. пед. учеб. заведений / Под ред. М.Л. Журавина, Н.К. Меньшикова. - М.: Академия. 2005. -445 c.

2. Дубровский, В.И. Валеология. Здоровый образ жизни [Текст] / В.И. Дубровский. - M.: RETORIKA - A: Флинта, 1999. - 560 с

3. Евсеев, Ю.И. Физическая культура [Текст]: Учеб. Пособие / Ю.И. Евсеев. - Ростов - н/Д: Феникс, 2004. - 384 с.

4. Жилкин, А.В. Легкая атлетика [Текст]: Учеб пособ. / А.И. Жилкин, В.С. Кузьмин, Е.В. Сидорчук. - М.: А кадемия, 2005. - 464 с.

5. Укран, М.Л., Смолевский, В.М., Шлемин, А.М. Атлетическая гимнастика [Текст] / М.Л. Укран, В.М. Смолевский, А.М. Шлемин. - М.: Физкультура и спорт. - 1965. - 72 с.

6. Физическая культура студента [Текст]: Учебник / Под ред. В.И. Ильинича. - М.: Гардарики, 1999. - 448 с. 
Тема 5. Психофизиологические основы учебного труда и интеллектуальной деятельности. Средства физической культуры в регулировании работоспособности

Практическая работа № 4. Средства физической культуры в регулировании работоспособности

Задачи:

1. Выявить симптомы усталости, утомления при умственной и физической нагрузке.

2. Освоить методики самооценки работоспособности, усталости, утомления

3. Научиться подбирать средства физической культуры для их направленной коррекции.

\section{Технология выполнения работы}

1. Ознакомиться с основными теоретическими положениями.

Работоспособность - потенциальная возможность человека выполнять целесообразную, мотивированную деятельность на заданном уровне эффективности в течение определенного времени. Зависит от внешних условий деятельности и психофизиологических резервов человека. Может рассматриваться как максимальная, оптимальная и сниженная.

Утомление - временное объективное снижение работоспособности под влиянием длительного воздействия нагрузки, сопровождающееся потерей интереса к работе, преобладанием мотивации на прекращение деятельности негативными эмоциональными и физиологическими реакциями.

Выделяют физическое и умственное, острое и хроническое, нервно-эмоциональное утомление. Признаки утомления представлены в табл. 
Усталость - комплекс субъективных переживаний, сопутствующих развитию состояния утомления и характеризующийся чувствами слабости, вялости, ощущениями физиологического дискомфорта, нарушениями в протекании психических процессов (памяти, внимания, мышления и др.).

Переутомление - накопление (кумуляция) утомления в результате неправильного режима труда и отдыха, не обеспечивающего необходимого восстановления сил и проявляющаяся в снижении работоспособности и продуктивности труда, появлении раздражительности, головных болях, расстройстве сна. Различают начинающееся, легкое, выраженное и тяжелое переутомление.

Таблица 7 - Внешние признаки утомления при умственном труде (по С.А. Косилову)

\begin{tabular}{|c|c|c|c|}
\hline \multirow{2}{*}{$\begin{array}{l}\text { Объект } \\
\text { наблюдения }\end{array}$} & \multicolumn{3}{|l|}{ Утомление } \\
\hline & незначительное & значительное & резкое \\
\hline Внимание & $\begin{array}{l}\text { Редкие } \\
\text { отвлечения }\end{array}$ & $\begin{array}{l}\text { Рассеянное, } \\
\text { частые } \\
\text { отвлечения }\end{array}$ & $\begin{array}{l}\text { Ослабленное, } \\
\text { реакции на } \\
\text { новые } \\
\text { раздражители } \\
\text { (словесные } \\
\text { указания } \\
\text { отсутствуют) } \\
\end{array}$ \\
\hline Поза & $\begin{array}{l}\text { Непостоянная, } \\
\text { потягивание ног, } \\
\text { выпрямление } \\
\text { туловища }\end{array}$ & $\begin{array}{l}\text { Частая } \\
\text { позы, пмена } \\
\text { головы в разороты } \\
\text { стороны, } \\
\text { облокачивания, } \\
\text { поддерживание } \\
\text { головы руками }\end{array}$ & $\begin{array}{l}\text { Стремление } \\
\text { положить } \\
\text { голову на стол, } \\
\text { вытянуться, } \\
\text { отклонившись } \\
\text { на спинку стула }\end{array}$ \\
\hline Движения & Точные & $\begin{array}{l}\text { Неуверенные, } \\
\text { замедленные }\end{array}$ & $\begin{array}{l}\text { Суетливые } \\
\text { движения рук и } \\
\text { пальцев } \\
\text { (ухудшение } \\
\text { почерка) }\end{array}$ \\
\hline
\end{tabular}




\begin{tabular}{|l|l|l|l|}
\hline $\begin{array}{l}\text { Интерес } \\
\text { материалу }\end{array}$ & $\begin{array}{l}\text { Живой интерес, } \\
\text { задавание } \\
\text { вопросов }\end{array}$ & $\begin{array}{l}\text { Слабый интерес, } \\
\text { отсутствие } \\
\text { вопросов }\end{array}$ & $\begin{array}{l}\text { Полное } \\
\text { отсутствие } \\
\text { интереса, апатия }\end{array}$ \\
\hline
\end{tabular}

Таблица 8 - Характеристика степени переутомления при умственном труде (по К.К. Платонову)

\begin{tabular}{|c|c|c|c|c|}
\hline \multirow[t]{2}{*}{ Симптомы } & \multicolumn{4}{|c|}{ Степень переутомления } \\
\hline & $\begin{array}{l}\text { начинающа } \\
\text { яся }\end{array}$ & легкая & выраженная & тяжелая \\
\hline $\begin{array}{l}\text { Снижение } \\
\text { дееспособност } \\
\text { и }\end{array}$ & $\begin{array}{l}\text { Мало } \\
\text { выражено }\end{array}$ & $\begin{array}{l}\text { Заметно } \\
\text { выражено }\end{array}$ & Выражено & $\begin{array}{l}\text { Резко } \\
\text { выражено }\end{array}$ \\
\hline $\begin{array}{l}\text { Появление } \\
\text { усталости при } \\
\text { умственной } \\
\text { нагрузке }\end{array}$ & $\begin{array}{l}\text { При } \\
\text { усиленной } \\
\text { нагрузке }\end{array}$ & $\begin{array}{l}\text { При } \\
\text { обычной } \\
\text { нагрузке }\end{array}$ & $\begin{array}{l}\text { При } \\
\text { облегченной } \\
\text { нагрузке }\end{array}$ & $\begin{array}{l}\text { Без } \\
\text { видимой } \\
\text { нагрузки }\end{array}$ \\
\hline $\begin{array}{l}\text { Компенсация } \\
\text { понижения } \\
\text { дееспособност } \\
\text { и волевым } \\
\text { усилием }\end{array}$ & $\begin{array}{l}\text { Не } \\
\text { требуется }\end{array}$ & Полностью & Частично & $\begin{array}{l}\text { Незначител } \\
\text { ьно }\end{array}$ \\
\hline $\begin{array}{l}\text { Эмоциональны } \\
\text { е изменения }\end{array}$ & $\begin{array}{l}\text { Временное } \\
\text { снижение } \\
\text { интереса к } \\
\text { учебе }\end{array}$ & $\begin{array}{l}\text { Временами } \\
\text { неустойчиво } \\
\text { сть } \\
\text { настроения }\end{array}$ & $\begin{array}{l}\text { Раздражительн } \\
\text { ость }\end{array}$ & $\begin{array}{l}\text { Угнетеннос } \\
\text { ть, резкая } \\
\text { раздражите } \\
\text { льн ость }\end{array}$ \\
\hline $\begin{array}{l}\text { Расстройство } \\
\text { сна }\end{array}$ & $\begin{array}{l}\text { Труднее } \\
\text { засыпать } \\
\text { или } \\
\text { просыпатьс } \\
\text { я } \\
\end{array}$ & $\begin{array}{l}\text { Постоянно } \\
\text { трудно } \\
\text { засыпать }\end{array}$ & $\begin{array}{l}\text { Сонливость } \\
\text { днем }\end{array}$ & Бессонница \\
\hline $\begin{array}{l}\text { Снижение } \\
\text { умственное } \\
\text { работоспособн } \\
\text { ости }\end{array}$ & Нет & $\begin{array}{l}\text { Труднее } \\
\text { сосредоточи } \\
\text { ться }\end{array}$ & $\begin{array}{l}\text { Временами } \\
\text { забывчивость }\end{array}$ & $\begin{array}{l}\text { Заметное } \\
\text { ослабление } \\
\text { внимания, } \\
\text { памяти } \\
\end{array}$ \\
\hline $\begin{array}{l}\text { Вегетативные } \\
\text { нарушения }\end{array}$ & $\begin{array}{l}\text { Временами } \\
\text { ощущение } \\
\text { тяжести в } \\
\text { голове }\end{array}$ & $\begin{array}{l}\text { Часто } \\
\text { ощущение } \\
\text { тяжести } \\
\text { голове }\end{array}$ & $\begin{array}{l}\text { Временами } \\
\text { головные боли, } \\
\text { снижение } \\
\text { аппетита }\end{array}$ & $\begin{array}{l}\text { Частые } \\
\text { головные } \\
\text { боли, } \\
\text { потеря } \\
\text { аппетита } \\
\end{array}$ \\
\hline Меры борьбы с & Упорядоче & Чередование & Организованн & Лечение \\
\hline
\end{tabular}




\begin{tabular}{|l|l|l|l|l|}
\hline $\begin{array}{l}\text { утомляемость } \\
\text { ю }\end{array}$ & $\begin{array}{l}\text { ние отдыха, } \\
\text { физическая } \\
\text { активность }\end{array}$ & $\begin{array}{l}\text { отдыха двигательно } \\
\text { й } \\
\text { активностью }\end{array}$ & $\begin{array}{l}\text { в отпуск } \\
\text { вотдх, уход }\end{array}$ & \\
\hline
\end{tabular}

\section{Таблица 9 - Внешние признаки утомления при занятиях физическими упражнениями (по Н.Б. Танбиану)}

\begin{tabular}{|c|c|c|c|}
\hline \multirow[t]{2}{*}{ Признак } & \multicolumn{3}{|c|}{ Степень утомления усталости } \\
\hline & небольшая & значительная & резкая (большая) \\
\hline Окраска кожи & $\begin{array}{l}\text { Небольшое } \\
\text { покраснение }\end{array}$ & $\begin{array}{l}\text { Значительное } \\
\text { покраснение }\end{array}$ & $\begin{array}{l}\text { Резкое } \\
\text { покраснение или } \\
\text { побледнение, } \\
\text { синюшность }\end{array}$ \\
\hline Потливость & Небольшая & $\begin{array}{l}\text { Большая } \\
\text { (плечевой пояс) }\end{array}$ & $\begin{array}{l}\text { Очень большая } \\
\text { (все туловище), } \\
\text { появление соли } \\
\text { на висках, на } \\
\text { рубашке, майке }\end{array}$ \\
\hline Движение & Быстрая походка & $\begin{array}{l}\text { Неуверенный } \\
\text { шаг, } \\
\text { покачивания }\end{array}$ & $\begin{array}{l}\text { Резкие } \\
\text { покачивания, } \\
\text { отставание при } \\
\text { ходьбе, беге, в } \\
\text { походе, } \\
\text { марше }\end{array}$ \\
\hline Внимание & $\begin{array}{l}\text { Хорошее, } \\
\text { безошибочное } \\
\text { выполнение } \\
\text { указаний }\end{array}$ & $\begin{array}{l}\text { Неточность в } \\
\text { выполнении } \\
\text { команд, ошибки } \\
\text { при перемене } \\
\text { направлений }\end{array}$ & $\begin{array}{l}\text { Замедленное } \\
\text { выполнение } \\
\text { команд, } \\
\text { воспринимаются } \\
\text { только громкие } \\
\text { команды }\end{array}$ \\
\hline Самочувствие & Никаких жалоб & $\begin{array}{l}\text { Жалобы на } \\
\text { усталость, боли } \\
\text { в ногах, одышку, } \\
\text { сердцебиение }\end{array}$ & $\begin{array}{lr}\text { Жалобы } & \text { на } \\
\text { усталость, } \\
\text { в нолах, одышку, } \\
\text { головную боль, } \\
\text { «жжение» } \\
\text { груди, тошноту } \\
\text { и даже рвоту. } \\
\text { Такое состояние } \\
\text { держится долго. }\end{array}$ \\
\hline
\end{tabular}


Оценка острого утомления (оригинальная версия А.Б. Леоновой и Н. Н. Савичевой, 1984).

Цель: оценка степени умственного утомления, развивающегося на протяжении одного рабочего дня у студентов (или лиц, деятельность которых связана с обработкой информационных потоков).

Материалы и оборудование: опросник для оценки степени утомления.

Ход работы Испытуемому предлагается опросник для оценки острого утомления.

Инструкция: Прочтите внимательно каждое из представленных ниже утверждений и соотнесите их с тем, как вы чувствуете себя в данный момент времени. Зачеркните ответ «Да», если оно соответствует вашим текущим ощущениям, или ответ «Нет» - если оно отсутствует. В случае, если Вы затрудняетесь с выбором ответа, подчеркните оба варианта «Да Нет».

Последовательно отвечайте на все пункты опросника не задумываясь долго над выбором ответа, как правило, первое ощущение оказывается наиболее точным!

Опросник для оценки острого утомления

\begin{tabular}{|l|l|l|}
\hline $\begin{array}{l}\text { № } \\
\text { п/п }\end{array}$ & Перечень утверждений & $\begin{array}{l}\text { Варианты } \\
\text { ответов }\end{array}$ \\
\hline 1 & Чувствую общую слабость & Да - Нет \\
\hline 2 & $\begin{array}{l}\text { Мне приходится заставлять себя как можно } \\
\text { быстрее дагировать на поступающую } \\
\text { информацию }\end{array}$ & Дат \\
\hline 3 & Я спокоен и собран & Да - Нет \\
\hline 4 & Мне душно & Да - Нет \\
\hline 5 & Хочется хоть немного отвлечься от работы & Да - Нет \\
\hline 6 & У меня тяжелая голова & Да - Нет \\
\hline 7 & Мне стало трудно думать & Да - Нет \\
\hline 8 & Чувствую себя раздраженным & Да - Нет \\
\hline 9 & Мне не хочется разговаривать & Да - Нет \\
\hline
\end{tabular}




\begin{tabular}{|l|l|l|}
\hline 10 & $\begin{array}{l}\text { Я не обращаю внимания на то, как идет работа у } \\
\text { моих товарищей (коллег) }\end{array}$ & Да - Нет \\
\hline 11 & У меня стали появяться паузы во время работы & Да - Нет \\
\hline 12 & Время течет медленно & Да - Нет \\
\hline 13 & Мне хочется встать и размяться & Да - Нет \\
\hline 14 & У меня устали глаза & Да - Нет \\
\hline 15 & Мне приходится напрягать слух & Да - Нет \\
\hline 16 & $\begin{array}{l}\text { У меня постоянно возникают сомнения в } \\
\text { правильности исполнения работы }\end{array}$ & Да - Нет \\
\hline 17 & Мне весело & Да - Нет \\
\hline 18 & Мне хочется работать & Да - Нет \\
\hline
\end{tabular}

Оценка результатов: полученные ответы по каждому пункту опросника переводятся в трехбалльную оценочную шкалу с учетом типа формулировки утверждения.

Ключ к оценке результатов тестирования острого утомления

Прямые утверждения (п. 1,2, 5-16) «Да» = 2 балла «Да» - «Нет» $=1$ балл «Нет» = 0 баллов

Обратные утверждения (п. 3,17,18) «Да» $=0$ баллов «Да» - «Нет»= 1 балл «Нет» = 2 балла

На основе полученных частных оценок подсчитывается общий показатель методики - индекс умственного утомления (ИУУ) - равный сумме баллов по всем пунктам опросника. Чем выше значение ИУУ, тем сильнее степень умственного утомления. Значения ИУУ могут варьироваться в диапазоне от 0 до 36 баллов

Интерпретация данных о степени выраженности умственного утомления основывается на следующих градациях ИУУ:

ИУУ < 10 баллов Отсутствие признаков умственного утомления $10 \leq$ ИУУ < 16 баллов Легкая степень умственного утомления $16 \leq$ ИУУ $<28$ баллов Умеренная степень умственного утомления ИУУ $\geq 28$ баллам Сильная степень умственного утомления 
Определение физической работоспособности по одышке (проводится групповым методом)

Материалы и оборудование: секундомер (либо часы с секундной стрелкой)

Ход работы В спокойном темпе без остановок испытуемый поднимается на 4-1 этаж типового жилого дома (или вашего учебного заведения). Такую же работу выполняют и другие члены группы.

Оценка результатов:

1. Субъективная - отсутствие одышки указывает на очень хорошую работоспособность

2. Объективная - контроль пульса Оценить результаты с помощью таблицы

Таблица 10 - Оценка результатов работоспособности

\begin{tabular}{|l|l|}
\hline Частота пульса, уд/мин & Состояние работоспособности \\
\hline Менее 100 & Отличное \\
\hline От 100 до 130 & Хорошее \\
\hline От 130 до 150 & Посредственное \\
\hline Более 150 & $\begin{array}{l}\text { Нежелательное (тренированность почти } \\
\text { отсутствует) }\end{array}$ \\
\hline
\end{tabular}

Методика оценки острого физического утомления (оригинальная версия R. Kinsman \& P. Weiser, 1973 - адаптирован А.Б. Леоновой, 1984).

Цель: оценка степени острого физического утомления, развивающегося на протяжении одного рабочего дня у студентов (или лиц, деятельность которых связана учебной деятельностью).

Материалы и оборудование: опросник для оценки степени острого физического утомления.

Ход работы Испытуемому предлагается опросник, состоящий из 18 коротких утверждений, включающих как прямую симптоматику физического дискомфорта (п. 1-10, группа симптомов усталости), так и 
сопутствующие им изменения со стороны группы проявлений психической нестабильности и истощения (п. 11-14), а также эмоционально-мотивационных оценок (п.15-18), группа симптомов мотивационной включенности.

Инструкция: Ниже приводится список утверждений, характеризующих те или симптомы, которые могут появляться у Вас в процессе работы. В зависимости от того, что вы чувствуете в данный момент времени, выберите нужный ответ. Зачеркните «Да», если у Вас присутствует данное переживание, или «Нет» - если оно отсутствует. При колебаниях в выборе ответа подчеркните оба ответа «Да - Нет». Старайтесь не оставлять пропусков при заполнении опросника и не задумывайтесь долго над выбором ответа.

Опросник для оценки острого физического утомления

\begin{tabular}{|l|l|l|}
\hline 1 & Ощущение усталости & Да - Нет \\
\hline 2 & Боль в мышцах & Да - Нет \\
\hline 3 & Учащенное дыхание & Да - Нет \\
\hline 4 & Слабость в ногах & Да - Нет \\
\hline 5 & Одышка & Да - Нет \\
\hline 6 & Учащенное сердцебиение & Да - Нет \\
\hline 7 & Сухость во рту & Да - Нет \\
\hline 8 & Дрожь в руках & Да - Нет \\
\hline 9 & Затрудненность дыхания & Да - Нет \\
\hline 10 & Истощение сил & Да - Нет \\
\hline 11 & Повышенное напряжение & Да - Нет \\
\hline 12 & Желание изменить характер деятельности & Да - Нет \\
\hline 13 & Взбудораженность & Да - Нет \\
\hline 14 & Общее ощущение дискомфорта & Да - Нет \\
\hline 15 & Точность и целенаправленность в действиях & Да - Нет \\
\hline 16 & Заинтересованность & Да - Нет \\
\hline 17 & Ощущение свежести & Да - Нет \\
\hline 18 & Энергичность & Да - Нет \\
\hline
\end{tabular}


Оценка результатов: полученные ответы по каждому пункту опросника переводятся в трехбалльную оценочную шкалу с учетом типа формулировки утверждения:

$$
\begin{aligned}
& \text { Прямые утверждения (п. } 1 \text { - 14) } \\
& \text { «Да» = } 2 \text { балла } \\
& \text { «Да» - «Нет»= } 1 \text { балл } \\
& \text { «Нет»= } 0 \text { баллов } \\
& \text { Обратные утверждения (п. } 15 \text { - 18) } \\
& \text { «Да» = } 0 \text { баллов } \\
& \text { «Да» - «Нет»= } 1 \text { балл } \\
& \text { «Нет»=2 балла }
\end{aligned}
$$

Основным показателем данной методики является индекс физического утомления (ИФУ), который подсчитывается как общая сумма баллов по 18 утверждениям. Оценки ИФУ могут принимать значения в диапазоне от 0 до 36 баллов. Для интерпретации получаемых оценок используют следующие градации ИФУ:

ИФУ < 11 баллов Отсутствие признаков физического утомления $11 \leq$ ИФУ < 18 баллов Легкая степень физического утомления $18 \leq$ ИФУ $<25$ баллов Умеренная степень физического утомления ИФУ $\geq 25$ баллам Сильная степень физического утомления

3. Подберите упражнения направленного воздействия для поддержания работоспособности и профилактики утомляемости при занятиях умственным трудом.

4. Подберите упражнения направленного воздействия для поддержания работоспособности и профилактики утомляемости тяжелым физическим трудом.

\section{Литература}


1. Гимнастика [Текст]: Учеб. пособ. для студ. высш. пед. учеб. заведений / Под ред. М.Л. Журавина, Н.К. Меньшикова. - М.: Академия. 2005. $-445 \mathrm{c}$.

2. Демирчоглян, Г.Г. Компьютер и здоровье [Текст] / Г.Г. демирчоглян. - М., 1995.

3. Евсеев, Ю.И. Физическая культура [Текст]: Учеб. Пособие / Ю.И. Евсеев. - Ростов - н/Д: Феникс, 2004. - 384 с.

4. Нифонтова, Л.Н., Павлова, Г.В. Физическая культура для людей, занятых малоподвижным трудом [Текст] / Л.Н. Нифонтова, Г.В. Павлова. M., 1993.

5. Физическая культура студента [Текст]: учебник/ Под ред. В.И. Ильинича. - М.: Гардарики, 1999. - 448 с.

6. Физическая культура [Текст]: Учеб. пособ. / Под ред. Е.В. Коневой. - Ростов н/Д: Феникс, 2006. - 558 с.

Тема 6. Общая физическая подготовка в системе физического воспитания

Практическая работа № 5. Индивидуальный план-график развития физических качеств.

Задачи:

1. Повторить методику развития двигательных качеств.

2. Научиться определять собственный уровень физической подготовленности.

3. Научиться подбирать средства для формирования должного уровня физической подготовленности

Задание. Составить индивидуальный план-график развития физических качеств.

Технология выполнения работы. 
1. Повторите методы развития двигательных качеств.

При составлении индивидуальных планов развития физических качеств необходимо знать характеристику физических качеств и методику их развития (табл. 11).

Таблица 11 - Физические качества и методы их развития

\begin{tabular}{|c|c|c|c|}
\hline №п/ா & $\begin{array}{l}\text { Физические } \\
\text { качества }\end{array}$ & Методы & Характеристики \\
\hline \multirow[t]{5}{*}{1} & \multirow[t]{5}{*}{ Сила } & $\begin{array}{l}\text { Максимальных } \\
\text { усилий }\end{array}$ & $\begin{array}{l}>90 \% \text { максимальных усилий } 1-3 \\
\text { повторений, 5-6 серий. Отдых } 4-8 \\
\text { мин (до восстановления). } 1 \text { раз в } 1-2 \\
\text { недели }\end{array}$ \\
\hline & & Повторный & $\begin{array}{l}\text { От } 40 \text { до } 80 \% \text { от максимальных } \\
\text { усилий. } \\
\text { 15-25 повторений, 3-6 серий. Отдых } \\
\text { до восстановления }\end{array}$ \\
\hline & & Интервальный & $\begin{array}{l}\text { От } 40 \text { до } 80 \% \text { от максимальных } \\
\text { усилий. 5-10 повторений. Отдых 2-4 } \\
\text { мин }\end{array}$ \\
\hline & & Круговой & $\begin{array}{l}\text { Серийное выполнение упражнений } \\
\text { по схеме на определенном месте } \\
\text { «станции». } \\
4-5 \text { «станций», 2-3 круга, от } 40 \text { до } \\
80 \% \text { от максимальных усилий. 5-10 } \\
\text { повторений. Отдых 2-4 мин }\end{array}$ \\
\hline & & Изометрический & $\begin{array}{l}\text { Максимальное напряжение 4-6 сек, } \\
\text { 3-5 серий. Отдых 30-60 сек }\end{array}$ \\
\hline \multirow[t]{3}{*}{2} & \multirow[t]{3}{*}{$\begin{array}{l}\text { Выносливост } \\
\text { ь }\end{array}$} & Повторный & $\begin{array}{l}\text { До } 30 \% \text { от рекордного. } \\
\text { 15-25 повторений, } \\
4-6 \text { серий. Отдых до восстановления }\end{array}$ \\
\hline & & Интервальный & $\begin{array}{l}\text { До } 30 \% \text { от рекордного. } \\
\text { повторений, } \\
\text { 4-6 серий. Отдых 2-4 мин } \\
\end{array}$ \\
\hline & & Круговой & $\begin{array}{l}\text { Серийное выполнение упражнений } \\
\text { по схеме на определенном месте } \\
\text { «станции», 5-6 «станций», 4-5 } \\
\text { кругов, до } 30 \% \text { от максимальных } \\
\text { усилий. 15-25 повторений. Отдых } \\
2-4 \text { мин }\end{array}$ \\
\hline
\end{tabular}




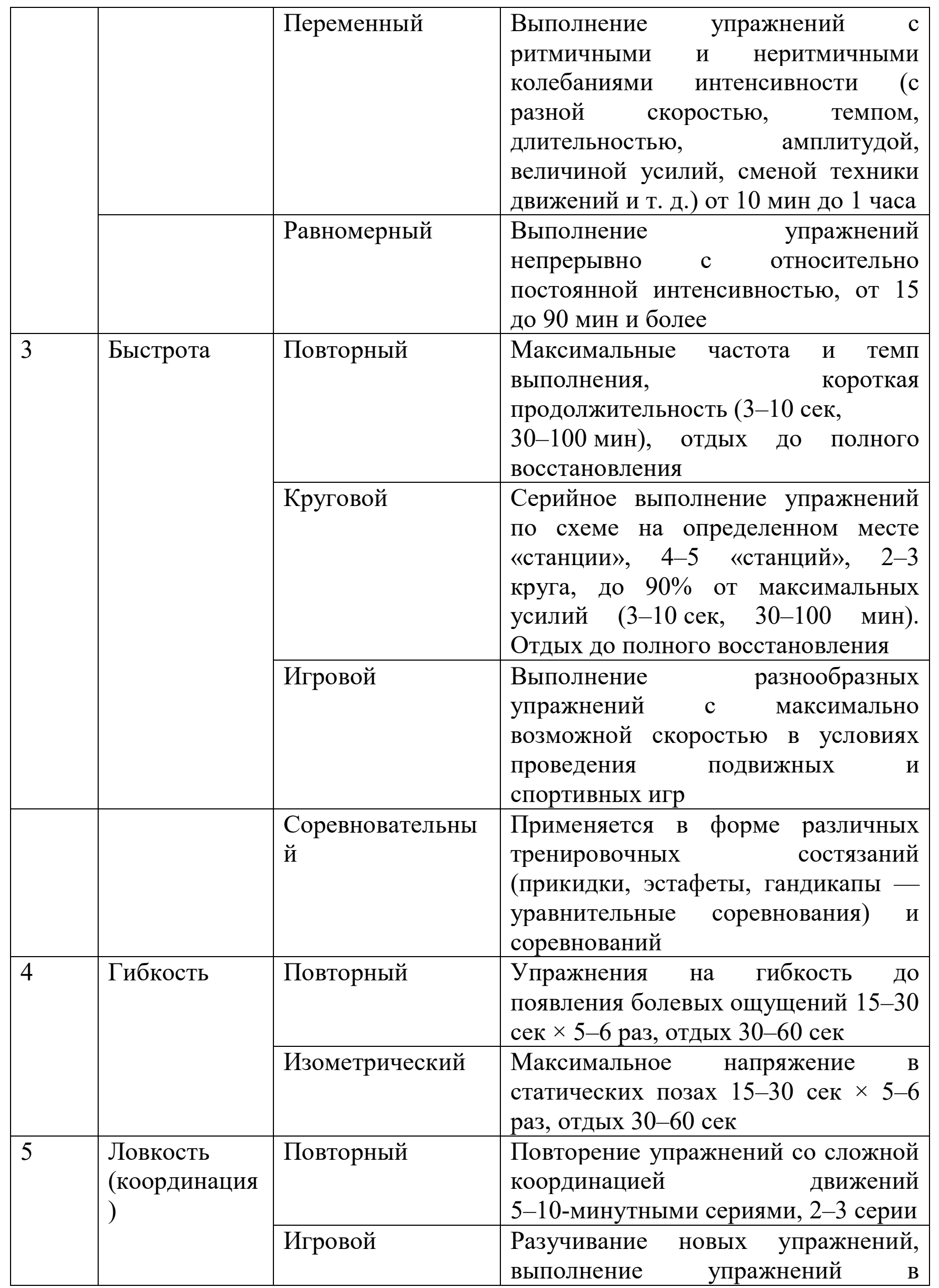




\begin{tabular}{|c|c|c|c|}
\hline & & & $\begin{array}{l}\text { меняющихся, } \quad \text { нестандартных } \\
\text { условиях } \\
\text { сериями, 2-3 серии }\end{array}$ \\
\hline & & $\begin{array}{l}\text { Соревновательны } \\
\text { й }\end{array}$ & $\begin{array}{lr}\text { Выполнение } & \text { упражнений } \\
\text { меняющихся, } & \text { в } \\
\text { условиях } & \text { нестандартных }\end{array}$ \\
\hline
\end{tabular}

2. Ознакомьтесь с приемами регулирования нагрузки.

В практике физического воспитания существует много способов регулирования нагрузки в занятиях. знания построения тренировки и применение этих способов должны быть нацелены на индивидуальный качественный результат тренировки.

Первый способ регулирования нагрузки ориентирован на количество повторений упражнения.

При втором способе регулирования нагрузки учитывается число участвующих в упражнении мышечных групп: чем их больше и чем они крупнее, тем значительнее физическая нагрузка.

Третий способ регулирования нагрузки связан с темпом упражнений: без учета особенностей упражнения самый нагрузочный - быстрый темп; в то же время быстрый темп иногда затрудняет упражнения для мелких и средних групп мышц; медленная ходьба утомляет быстрее, чем ходьба в среднем темпе; силовые упражнения в медленном темпе оказывают большее воздействие на организм человека по сравнению с упражнениями, выполняемыми в быстром или среднем темпе.

Четвертый способ регулирования нагрузки ориентирован на амплитуду движений: при ее увеличении общая нагрузка на организм возрастает, хотя возможны исключения, например, поднимание опускание ног из положения лежа на спине легче под углом 90 градусов, чем под углом 45-30 градусов.

При пятом способе регулируется сложность упражнения; чем оно сложнее по своему построению, тем большее число мышц участвуют в его 
выполнении, тем сосредоточеннее внимание и, следовательно, больше нагрузка, значительно быстрее наступает утомление.

Шестой способ регулирования нагрузки связан с выбором исходного положения упражнения, определяющего уровень нагрузки на организм.

При седьмом способе регулируются продолжительность, время и характер отдыха между упражнениями: для установления частоты и длительности интервалов отдыха при одной и той же суммарной их длительности нужно учитывать, что работоспособность организма бывает выше при коротких, но частых, чем при длительных, но редких интервалах отдыха, предпочтительнее будет активный отдых даже при упражнениях с большими отягощениями, тогда он более эффективен.

Восьмой способ связан с регулированием мощности нагрузки: чем она больше, тем больше нагрузка; с увеличением мощности работы сокращается время ее выполнения.

Девятый способ регулирования нагрузки связан с влиянием на степень и характер мышечного напряжения: чем напряженнее работа, тем она утомительнее; труднее выполнять работу, сопряженную с быстрыми и максимальными мышечными напряжениями.

3. Ознакомьтесь с приемами выбора подходящей для себя зоны физической нагрузки.

Период приспособления человека к нагрузкам различен в зависимости от психофизиологических особенностей индивида, его физической подготовленности, характера движения и др. С учетом этого применяют разные способы повышения нагрузки.

Прямолинейно-восходящее повышение нагрузки позволяет постепенно втягивать организм в работу при относительно низком уровне физической подготовленности. лучше соблюдать небольшие темпы 
прироста и достаточно длительные интервалы отдыха, чтобы очередная нагрузка приходилась на фазу повышенной работоспособности.

Ступенчатое повышение нагрузки применяется для резкого стимулирования организма на основе предварительно созданных функциональных возможностей. форма предусматривает скачкообразное увеличение нагрузки с последующим ее сохранением на протяжении нескольких занятий.

Волнообразное повышение нагрузки способствует максимальному повышению нагрузки за счет периодического снижения нагрузки и последующего ее увеличения до более высокого уровня. При этом полностью включаются адаптационные механизмы в ответ на примененную нагрузку. Для воспитания выносливости и скоростных способностей используются различные зоны физических нагрузок. В основу классификации зон положен характер физиологических сдвигов в организме, происходящих под воздействием специальных упражнений.

Преимущественная направленность упражнений в каждой зоне зависит, прежде всего, от интенсивности и продолжительности движений и метода тренировки (табл. 12).

Таблица 12 - Интенсивность физических нагрузок при развитии физических качеств

\begin{tabular}{|l|l|l|l|}
\hline Зона нагрузки & Интенсивность & $\begin{array}{l}\text { ЧСС } \\
\text { (уд/мин })\end{array}$ & $\begin{array}{l}\text { Развитие } \\
\text { специальных } \\
\text { качеств }\end{array}$ \\
\hline 1 - аэробная & Малая & $120-130$ & $\begin{array}{l}\text { Общая } \\
\text { выносливость }\end{array}$ \\
\hline $\begin{array}{l}\text { 2- на пороге } \\
\text { анаэробного } \\
\text { обмена }\end{array}$ & Умеренная & $130-150$ & $\begin{array}{l}\text { Базовая } \\
\text { выносливость, } \\
\text { экономизация } \\
\text { техники }\end{array}$ \\
\hline
\end{tabular}




\begin{tabular}{|l|l|l|l|}
\hline $\begin{array}{l}3 \text { - в смешанном } \\
\text { аэробно-анаэробн } \\
\text { ом режиме }\end{array}$ & Большая & $150-180$ & $\begin{array}{l}\text { Специальная } \\
\text { выносливость }\end{array}$ \\
\hline $\begin{array}{l}4 \text { - в анаэробном } \\
\text { (гликолитическом } \\
\text { режиме }\end{array}$ & Субмаксимальная & $\begin{array}{l}180 \quad \text { и } \\
\text { выше }\end{array}$ & $\begin{array}{l}\text { Силовая } \\
\text { выносливость }\end{array}$ \\
\hline 5 - спринт & Максимальная & $\begin{array}{l}180 \\
\text { выше }\end{array}$ & $\begin{array}{l}\text { Скорость } \\
\text { мощность } \\
\text { движений }\end{array}$ \\
\hline
\end{tabular}

1 При малой интенсивности создаются предпосылки для развития выносливости: расширяется сеть кровеносных сосудов в скелетных мышцах и сердечной мышце.

2 При умеренной интенсивности действует аэробное энергообеспечение работы.

3 В зоне большой интенсивности к аэробному энергообеспечению постепенно подключается анаэробное. Однако устойчивое состояние между производством энергии и удалением продуктов метаболизма из организма сохраняется.

4 В зоне субмаксимальной интенсивности работа протекает при недостатке кислорода. Субъективно это ощущается как сильное утомление. Переход к анаэробному энергообеспечению у разных людей происходит неодинаково. У физически нетренированных он может наступать даже при ЧСС 140-150 уд/мин, у тренированных — при ЧСС 160-165 уд/мин.

5 В зоне максимальной интенсивности развивается анаэробное энергообеспечение.

4. Проанализируйте свой уровень развития двигательных качеств.

Выполните нормативы ГТО, тестирующие силовые, скоростные способности, выносливость, гибкость. Обоснуйте выбор физического качества, подлежащего развитию. 
5. Составьте план-график совершенствования физического качества на месяц.

Результат оформите в виде таблицы.

План-график развития (физическое качество, указать)

\begin{tabular}{|c|c|c|c|c|c|c|c|c|c|}
\hline \multirow[t]{3}{*}{ Упражнения, нагрузка } & \multicolumn{9}{|c|}{ Недели } \\
\hline & \multicolumn{7}{|c|}{1} & \multicolumn{2}{|c|}{2} \\
\hline & 1 & 2 & 3 & 4 & 5 & 6 & 7 & 1 & 2 \\
\hline 1. Приседания & + & & + & & + & & & + & \\
\hline
\end{tabular}

\section{Литература}

1. Матвеев, Л.П. Теория и методика физической культуры [Текст]: Учеб. для ин-ов физической культуры / Л.П. Матвеев. - М.: ФиС. - 1991. $502 \mathrm{c}$.

2. Теория и методика физической культуры (курс лекций) [Текст]: Учебное пособие / Под ред. Ю.Ф. Курамшина, В.И. Попова. - СПб. -1999. $-324 \mathrm{c}$.

3. Холодов, Ж.К., Кузнецов, В.С. Теория и методика физического воспитания и спорта [Текст]: Учеб. пособие для студ. высш. учеб. Заведений / Ж.К. Холодов, В.С. Кузнеов. - М.: Академия. -2000. - 480 с.

\section{Тема 7. Спорт. Индивидуальный выбор видов спорта или систем физических упражнений}

Практическая работа № 6. Студенческий спорт

Задачи:

1. Актуализировать знания о формах занятий спортом студентами.

2. Научиться составлять положение о соревнованиях.

Задание. Составьте положение о соревнованиях по одному из видов спорта, культивирующемся в вузе. 


\section{Технология выполнения работы}

1. Ознакомьтесь с теоретическими положениями по теме.

Положение о соревновании - это основной нормативный документ, регламентирующий отношения между организаторами соревнования, его участниками и судьями. Положение о соревновании дает право на финансирование мероприятия, раскрывает основное содержание состязаний и определяет порядок их проведения.

Положение о соревновании состоит из следующих разделов:

\section{Цели и задачи.}

В этом разделе указывают цель и задачи предстоящего соревнования, событие, которому оно посвящено.

В различных соревнованиях ставятся определенные цели и задачи:

- привлечение к регулярным занятиям физической культурой и спортом;

- развитие вида спорта, по которому проводится соревнование;

- повышение спортивного мастерства и выявление перспективных спортсменов;

- для формирования сборных команд учебных заведений, районов и т.д. для участия в предстоящих соревнованиях;

- популяризация пропаганда данного вида спорта.

В соответствии с поставленными целями и задачами проводящая соревнование организация намечает время и место проведения соревнования.

\section{Руководство проведением соревнования.}

В этом разделе указывается, кто организует соревнование и руководит им (готовит место соревнования, снабжает инвентарем и оборудованием, обеспечивает прием, размещение, организует питание и отправку участников, судей и представителей). 
Положение определяет, кто оплачивает командировочные расходы (проезд от места жительства к месту соревнований и обратно, расходы по размещению, питанию участников и тренеров, судей).

Здесь также указывается состав судейской коллегии.

\section{Сроки и место проведения соревнования.}

В этом разделе четко и точно указываются время и место спортивных сооружений, на которых планируется проведение соревнования.

В этом же разделе точно указываются сроки прибытия и отъезда иногородних команд.

В случае, если программа соревнования долгосрочная и требует несколько дней соревнований, после двух дней состязаний рекомендуется делать один день отдыха для восстановления спортсменов.

\section{Участники соревнования.}

В этом разделе указывается, кто допускается к участию в соревновании, и какие требования предъявляются к его участникам. В Положении должны быть оговорены особенности состава участников и условия, по которым их допускают к соревнованиям, указаны численность участников, тренеров, представителей, судей. Определяется возраст участников, допускаемых к соревнованию, требуемая спортивная квалификация, состояние здоровья. Для командного зачета определяют число спортсменов, дающих зачетные очки.

Здесь также указывается перечень документов, необходимых для тренера (представителя), согласно которым устанавливают принадлежность спортсмена к команде, наличие паспорта с пропиской, медицинского допуска и т.д. В Положении можно оговаривать условия по параллельному зачету одного или нескольких спортсменов или ряда команд.

Программа соревнования и условия проведения соревнования. 
В этом разделе более конкретизировано должна быть оговорена программа соревнования, указаны способы розыгрыша и оценка результатов. Программа соревнований предусматривает по каждому виду точное представление на каждый день, расписанное по часам.

\section{Порядок определения победителей.}

В этом разделе записывают, каким образом определяют победителей личного первенства и общекомандного зачета. Личные места определяют по выступлению каждого спортсмена, а командные места - по количеству зачетных участников по наименьшей или наибольшей сумме очков, набранных участниками в индивидуальных и командных первенствах. Для решения спорных вопросов указывается, что при одинаковых результатах, набранных спортсменами, преимущество отдается тому, который показал лучший результат в первой или второй попытке, в зависимости от вида спорта.

При составлении Положения на большой промежуток времени (квартал, полугодие, год) оговаривается организация многоэтапных соревнований. При выявлении победителей в общекомандном зачете обычно устанавливают для этапов и соревнований поправочные коэффициенты.

Место, занятое каждой командой, умножают на соответствующий коэффициент, затем суммируют и по наименьшему (наибольшему) количеству баллов определяют первое и последующие места в общекомандном зачете. Если спортивная организация не участвовала в одном из соревнований, то ей начисляют баллы, полученные от умножения соответствующего коэффициента на сумму очков, равную числу соревновавшихся организаций в общекомандном зачете плюс один штрафной бал, если оговорено в этом разделе. 
Во всех случаях при равном количестве очков у нескольких команд преимущество получает та из них, которая имеет больше первых мест, а при равенстве этого показателя - больше вторых и т.д.

Раздел положения о порядке определения победителей дает право судейской коллегии проводить награждение.

\section{Награждение победителей.}

В этом разделе четко оговаривается, какими призами награждаются победители и призеры в командных и индивидуальных видах спорта. Указывается,

какие призы вручаются командам - победительницам в общекомандном зачете.

Главные призы устанавливает, как правило, проводящая спортивное мероприятие организация, но могут наряду с ней установить спонсоры, меценаты и т.д.

Традиционно командам за первые места вручают переходящие призы, вымпелы и дипломы, за вторые и третьи места - дипломы второй и третьей степени и памятные вымпелы.

Призеров в личном зачете награждают за первое место - призом, ценном подарком, дипломами, лентой чемпионата; за второе и третье места - дипломами соответствующих степеней, призами или именными подарками.

Могут быть установлены денежные призы.

Нужно иметь в виду, что чем больше будет установлено призов, тем выше заинтересованность в соревнованиях и острее спортивная борьба.

Комплектованием призового фонда занимается оргкомитет с проводящей соревнование организацией.

При подведении итогов соревнований отмечают тренеров успешно выступавших команд, чемпионов и призеров в личном зачете. Тренерам 
могут быть вручены памятные подарки, призы, дипломы, грамоты, свидетельства, медали и т.д.

\section{Заявки на участие в соревнованиях.}

В этом разделе должна быть информация о форме и сроках подачи предварительных и окончательных заявок на участие в соревнованиях, соответствующие документы на каждого участника.

Заявка должна подаваться спортивной организацией. $\mathrm{O}$ своем участии в соревнованиях коллектив должен сообщить не позднее указанных в Положении сроках подачи заявок.

В заявке указывают фамилию, имя (полностью), отчество спортсмена, год рождения, разряд или спортивное звание. Против каждой фамилии врач должен поставить отметку о допуске к соревнованиям, подпись врача. Заявку подписывает руководитель учреждения, организации, официальный представитель или тренер. В конце заявки врач подписывает сведения об общем количестве спортсменов, допущенных к соревнованиям; ставится фамилия доктора, его подпись и печать врачебно-физкультурного диспансера или кабинета врачебного контроля.

В конце заявки стоит подпись руководителя спортивной организации, которую представляет команда.

2. Составьте положение о соревнованиях по одному из видов спорта, культивирующемуся в вузе, придерживаясь представленной схемы

\section{Положение о соревнованиях по (указать вид спорта)}

1. Цели и задачи.

2. Руководство проведением соревнования;

3. Сроки и место проведения соревнования;

4. Участники соревнования;

5. Программа соревнования и условия проведения соревнования;

6. Порядок определения победителей; 
7. Награждение победителей;

8. Заявки на участие в соревнованиях.

\section{Литература:}

12. Бальсевич, В.К. Физическая культура для всех и для каждого [Текст] / В.К. Бальсевич. - М.: Физкультура и спорт, 1988. - С.25.

13. Бутин, И.М. Лыжный спорт [Текст]: Учеб. пособие для студ. высш. пед. учеб. Заведений / И.М. Бутин. - М.: Академия. - 2000. - 368 с.

14. Вяткин, Л.А. Туризм и спортивное ориентирование [Текст]: учеб. пособ.: рек УМО / Л.АВяткин и др. - М.: Академия, 2004. - 208 с.

15. Гимнастика [Текст]: Учеб. пособ. для студ. высш. пед. учеб. заведений / Под ред. М.Л. Журавина, Н.К. Меньшикова. - М.: Академия. 2005. $-445 \mathrm{c}$.

16. Евсеев, Ю.И. Физическая культура [Текст]: Учеб. пособие. / ЮИ. Евсеев. - Ростов - н/Д: Феникс, 2004. - 384 с.

17. Жилкин, А.В. Легкая атлетика [Текст]: учеб пособ. / А.И. Жилкин, В.С. Кузьмин, Е.В. Сидорчук. - М.: Академия, 2005. - 464 с.

18. Нестерковский, Д.И. Баскетбол: теория и методика обучения [Текст]: учеб. пособие / Д.И. Нестерковский. - М.: Академия, 2006. - 336 с.

\section{Тема 8. Профессионально-прикладная физическая культура}

Практическая работа № 7 . Профессионально-прикладная физическая культура

Цель: Ознакомиться с методиками подбора средств для проведения занятий с оздоровительной и рекреационной направленностью в целях профилактики профессиональных заболеваний.

Задание. Составьте комплекс упражнений ППФП применительно к вашей профессиональной деятельности. 


\section{Технология выполнения задания}

1. Ознакомьтесь с основными теоретическими положениями

Классификация видов труда и его специфика

При выполнении трудовых действий или операций нагрузка чаще всего приходится на определенные функциональные системы. Существуют различные виды трудовой деятельности, которые значительно различаются по организации рабочего процесса, распределению нагрузки, степени нервно-эмоционального напряжения. Условно можно выделить следующие группы:

1. Труд инженеров, экономистов, бухгалтеров, работников канцелярий, требующий преимущественно напряжения мыслительных процессов и выполняемый по заранее разработанному плану.

2. Управленческий характер труда типичен для руководителей учреждений, предприятий, больших и малых коллективов, для преподавателей. Его отличительные черты - неравномерность нагрузки, необходимость принимать нестандартные решения, возможность возникновения конфликтных ситуаций.

3. Для труда научных работников, конструкторов, писателей, композиторов, артистов, художников характерно создание новых продуктов творческой деятельности, нерегламентированный график, периодически возникающее повышение степени нервноэмоционального напряжения.

4. Операторский труд охватывает большую группу профессий, связанных с управлением машинами, оборудованием, технологическими процессами. Работа отличается особой ответственностью и высоким нервно-эмоциональным напряжением.

5. Труд с большой нагрузкой на мелкие группы мышц, требующий напряжения отдельных анализаторов и функций внимания, типичен для наборщиков, контролеров, сборщиков и др. 
6. Труд медицинских работников связан с большой ответственностью, часто с дефицитом информации, нужной для принятия правильного решения, сложностью взаимоотношений с больными, что обусловливает его высокое нервно-эмоциональное напряжение.

7. Образовательная деятельность. Обучение студентов направлено на освоение новых знаний требует от обучающихся напряжения памяти, внимания, мыслительных процессов, необходимых для восприятия и воспроизведения новой информации.

Методика подбора средств проведения занятий с оздоровительной и рекреационной направленностью, с целью профилактики профессиональных заболеваний специалиста обусловлена необходимостью восстановления после работы. Для этого успешно используются бассейны, тренажерные залы, спортивнооздоровительные комплексы. Средствами восстановления являются спортивные игры (волейбол, настольный теннис, бадминтон, городки и т.д.). Так как утомление, развивающееся при разных видах деятельности будет не одинаковым, рекомендуемые формы и средства послерабочего восстановления также будут различны. В таблице представлена схема наиболее целесообразных восстановительных воздействий после работы для разных профессиональных групп.

Таблица 13 - Формы восстановительных занятий после работы для разных профессиональных групп (по Н.А. Мусаелову, Л.Н. Нифонтовой, 1985)

\begin{tabular}{|l|l|l|lr|}
\hline $\begin{array}{l}\text { Формы } \\
\text { послерабочего } \\
\text { восстановления }\end{array}$ & $\begin{array}{l}\text { Длительн } \\
\text { ость }\end{array}$ & $\begin{array}{l}\text { Место } \\
\text { проведения }\end{array}$ & \multicolumn{2}{|l|}{ для } \\
\hline $\begin{array}{l}\text { Восстановительна } \\
\text { я гимнастуется }\end{array}$ & $10-12$ мин & $\begin{array}{l}\text { На месте работы, } \\
\text { учебы }\end{array}$ & $\begin{array}{l}\text { Для } \\
\text { умственным }\end{array}$ \\
\hline
\end{tabular}




\begin{tabular}{|c|c|c|c|}
\hline $\begin{array}{l}\text { сочетании с } \\
\text { самомассажем и } \\
\text { функциональной } \\
\text { музыкой }\end{array}$ & & $\begin{array}{l}\text { специальном } \\
\text { помещении }\end{array}$ & $\begin{array}{l}\text { малоподвижным } \\
\text { трудом }\end{array}$ \\
\hline $\begin{array}{l}\text { Занятия с } \\
\text { использованием } \\
\text { тренажеров } \\
\text { технических } \\
\text { устройств }\end{array}$ & $15-25$ мин & $\begin{array}{l}\text { В тренажерном } \\
\text { зале }\end{array}$ & $\begin{array}{l}\text { Для занятых легким } \\
\text { физическим и } \\
\text { умственным трудом }\end{array}$ \\
\hline $\begin{array}{lr}\text { Занятия } & \text { с } \\
\text { использованием } & \\
\text { аппаратов } & \\
\text { пассивного } & \\
\text { действия } & \text { и } \\
\text { массажеров } & \text { в } \\
\text { сочетании } & \text { с } \\
\text { гигиеническими } & \\
\text { процедурами } & \text { и } \\
\text { дыхательными } & \\
\text { упражнениями } & \end{array}$ & 20-25 мин & $\begin{array}{l}\text { В тренажерном } \\
\text { зале, бассейне, } \\
\text { фитнес-клубе }\end{array}$ & $\begin{array}{l}\text { Для } \\
\text { тяжелым } \\
\text { физическим трудом }\end{array}$ \\
\hline $\begin{array}{l}\text { Занятия } \\
\text { использованием } \\
\text { технических } \\
\text { устройств, } \\
\text { аппаратов, } \\
\text { механотерапии, } \\
\text { массажеров } \\
\text { сочетании } \\
\text { дыхательными } \\
\text { упражнениями } \\
\text { упражнениями } \\
\text { расслабление }\end{array}$ & 15-20 мин & $\begin{array}{l}\text { В спортивном } \\
\text { клубе, } \\
\text { восстановительно } \\
\text { м центре на } \\
\text { предприятии }\end{array}$ & $\begin{array}{l}\text { Для занятых трудом } \\
\text { средней физической } \\
\text { тяжести }\end{array}$ \\
\hline $\begin{array}{l}\text { Сочетание } \\
\text { гидровосстановле } \\
\text { ния } \\
\text { упражнениями на } \\
\text { расслабление } \\
\text { дыхание, } \\
\text { самомассажем } \\
\end{array}$ & 15-20 мин & $\begin{array}{l}\text { Бассейне, } \\
\text { спортивном } \\
\text { клубе, } \\
\text { восстановительно } \\
\text { м центре на } \\
\text { предприятии, } \\
\text { дома }\end{array}$ & $\begin{array}{ll}\text { Для } & \text { занятых } \\
\text { тяжелым } & \\
\text { физическим } & \text { трудом } \\
\text { и трудом средней } \\
\text { физической тяжести }\end{array}$ \\
\hline $\begin{array}{l}\text { Регулирование } \\
\text { психического } \\
\text { состояния }\end{array}$ & 20-25 мин & $\begin{array}{lr}\text { На } & \text { производстве, } \\
\text { (в } & \text { комнате } \\
\text { психорегуляции) } \\
\text { или }\end{array}$ & $\begin{array}{l}\text { Для занятых } \\
\text { умственным и } \\
\text { нервноэмоциональн } \\
\text { ым трудом }\end{array}$ \\
\hline
\end{tabular}




\begin{tabular}{|l|l|l|l|}
\hline & & самостоятельно & \\
\hline $\begin{array}{l}\text { Спортивные и } \\
\text { подвижные игры, } \\
\text { плавание }\end{array}$ & $20-30$ мин & $\begin{array}{l}\text { На спортивных } \\
\text { сооружениях, } \\
\text { открытых } \\
\text { площадках }\end{array}$ & $\begin{array}{l}\text { Для ваб категорий } \\
\text { работающих }\end{array}$ \\
\hline
\end{tabular}

2. Опишите особенности профессии.

3. Укажите физические качества, нервно-психические особенности личности, необходимые для эффективного выполнения профессиональной деятельности.

4. Перечислите группы физических упражнений, необходимые для совершенствования указанных качеств.

5. Составьте комплекс упражнений (не менее 6) ППФП

\section{Литература}

1. Виленский, М.Я., Ильинич, В.И. Физическая культура работников умственного труда [Текст] / М.Я. Виленский, В.И. Ильинич. - М.: Знание. $-1987 .-96$ c. 2

2. Мусаелов, Н.А. Нифонтова, Г.В. Производственная физическая культура в трудовом коллективе. [Текст] / Н.А. Мусаева, Г.В. Нифонтова М.: Профиздат. - 1985. - 149 с.

3. Пряжников, Н.С., Пряжникова, Е.Ю. Психология труда и человеческого достоинства [Текст]: Учеб. пособие для студ. высш. учеб. Заведений / Н.С. Пряжников, Е.Ю. Пряжникова. - М.: Академия. - 2001. $480 \mathrm{c}$.

4. Физическая культура студента [Текст]: Учебник / Под ред. В.И. Ильинича. - М.: Гардарики, 1999. - 448 с. 


\section{ЧАСТЬ III. ТЕСТОВЫЕ ЗАДАНИЯ}

Тема 1. Физическая культура в общекультурной и профессиональной подготовке студентов

1. По какому принципу определяется содержание работы при организации физического воспитания в вузе?

А) принципу единства общей и профессионально-прикладной физической подготовки;

Б) принципу дифференцированного подхода к образовательному процессу;

В) принципу содействия всестороннему гармоничному развитию человека.

2. Какой показатель не является показателем физического совершенства человека?
А) деловая активность;
Б) уровень здоровья;
В) физическая подготовленность.

3. При занятиях физической культурой и спортом обязательным является...
А) тщательный контроль за состоянием здоровья;
Б) систематическое посещение занятий;
В) наличие начальной физической подготовки.

4. К социально обусловленным факторам физического развития человека не относится...

А) условия жизни; 
Б) производственная деятельность;

В) наследственность.

5. Функциональная подготовка отражает...

А) общие рекомендации для занятий физическими упражнениями;

Б) потенциал общей и специальной выносливости;

В) состояние тренированности органов, обеспечивающих кровообращение и транспорт кислорода в организме.

6. Какое положение о роли занятий физической культурой в сохранении и укреплении здоровья человека сформулировано неверно?

А) физические упражнения способствуют урежению частоты сердечных сокращений;

Б) физические упражнения не способствуют продлению творческой активности человека;

физические упражнения предупреждают преждевременное старение.

7. Одной из специфических функций физической культуры является...

А) организация содержательного досуга, предупреждение утомления и восстановления временно утраченных функций организма;

Б) достижение максимальных результатов в реализации физических и морально-волевых возможностей человека;

В) создание возможности удовлетворения естественных потребностей человека в двигательной активности. 
8. Какие функции физической культуры обеспечивают восстановление временно утраченных функций организма и направлены на предупреждение утомления?
А) спортивные;
Б) рекреативные;
В) прикладные.

9. Физическое совершенствование это...

А) одна из сфер социальной деятельности человека, направленная на укрепление здоровья, развитие физических качеств;

Б) процесс физического образования и воспитания, направленный на развитие индивидуальных физических способностей;

В) социально-педагогический процесс, направленный на укрепление здоровья, гармоническое развитие форм и функций организма человека.

10. Физическое воспитание - это...

А) педагогический процесс, направленный на формирование физической культуры личности;

Б) процесс изменения морфологических и функциональных свойств организма;

В) деятельность, направленная на укрепление здоровья, развитие физических способностей.

11. Какого человека можно назвать физически совершенным?
А) имеющего спортивное телосложение;
Б) здорового;
В) показывающего высокую физическую активность. 
12. Какие мероприятия, проводимые в вузе, направлены на привлечение студентов к регулярным занятиям физическими упражнениями, укрепление здоровья?
А) малые формы физической культуры;
Б) массовые физкультурные и спортивные мероприятия;
В) самостоятельные занятия.

13. Физическое развитие - это...

А) биологический процесс измерения форм и функций организма человека в продолжении индивидуальной жизни;

Б) процесс физического образования и воспитания, направленный на развитие индивидуальных физических способностей;

В) педагогический процесс формирования физической культуры личности.

14. К какому учебному отделению относятся студенты, показывающие хорошую общую физическую подготовленность и желающие углубленно заниматься спортом?
А) основному;
Б) специальному;
В) спортивному.

15. Физическая культура - это...

А) специализированная область деятельности, связанная с выявлением и демонстрацией физических возможностей людей;

Б) часть общей культуры общества, отражающая способы, результаты и условия физкультурной деятельности, направленные на развитие физических и психических способностей человека, укрепление его здоровья, повышение работоспособности; 
В) система организации и проведения соревнований по различным видам спорта и комплексам физических упражнений

16. Какое зачетное требование к студентам по дисциплине «Физическая культура» сформулировано неверно?
А) посещение не менее 50\% занятий;
Б) владение навыками передвижения на лыжах, плавания;
В) выполнение нормативов ГТО, спортивно-техничекой подготовки.

17. Физические упражнения в режиме дня студентов направлены на...

А) более эффективное усвоение учебного материала, ускорение процесса физического совершенствования;

Б) укрепление здоровья, повышение умственной и физической работоспособности;

В) привлечение студентов к регулярным занятиям физической культурой и спортом

18. Какой принцип не содержит система физического воспитания России?
А) принцип всестороннего гармоничного развития личности;
Б) принцип оздоровительной направленности;
В) принцип научности.

19. Какой принцип лежит в основе выбора средств физической культуры для занятий, регулирования физических нагрузок?
А) научно-исследовательский;
Б) оздоровительной направленности;
В) достижения физического совершенства. 
20. Как называется отделение для занятий физической культурой, в которое распределяются студенты, имеющие ослабленное здоровье, низкий уровень физической подготовленности?
А) специальное;
Б) спортивного совершенствования;
В) подготовительное.

21. Достижение какого эффекта следует учитывать при решении задач физического воспитания?
А) оздоровительного;
Б) укрепляющего;
В) поддерживающего.

22. Цель физического воспитания в вузе - ...
A) содействие подготовке гармонично развитых, высококвалифицированных специалистов;

Б) обучение студентов двигательным умениям и навыкам, управлению движением тела во времени и пространстве;

В) вооружение студентов теоретическими знаниями по использованию двигательных умений и навыков в различных условиях жизни и деятельности.

Тема 2. Основы здорового образа жизни. Физическая культура в обеспечении здоровья

1. Объективными критериями оценки физической нагрузки являются показатели:

а) нервной системы; 

б) мочевыделительной системы;
в) кардиореспираторной системы;
г) эндокринной системы.

2. Что не относится к основным гигиеническим средствам, физической культуры? (несколько правильных ответов)
а) правила личной гигиены;
б) психотерапия;
в) соблюдение рационального распорядка дня;
г) биологически активные добавки;
д) оптимальные санитарно-гигиенические условия быта;
е) занятия физическими упражнениями.

3. Закаливание это:

a) способность организма противостоять различным заболеваниям;

б) способность организма противостоять различным метеофакторам;

в) повышение сопротивляемости организма к различным внешним воздействиям.

4. Укажите правильную последовательность водных процедур:

а) растирание снегом, обливание, купание в открытом водоёме, душ, влажное обт

б) влажное обтирание, обливание, душ, купание в открытом водоёме, растирание снегом, моржевание;

в) влажное обтирание, душ, обливание, растирание снегом, купание в открытом водоёме, моржевание.

5. Массажные движения выполняются:

а) от периферии к центру;

б) от центра к периферии; 
в) в зависимости от локализации массируемого участка.

6. Массаж - это:

a) особый метод комплексного лечебно-профилактического воздействия на все жизненно-важные системы организма;

б) совокупность специальных приемов, посредством которых оказывают дозированное механическое и рефлекторное воздействие на ткани и органы человека;

в) метод, с помощью которого можно частично или полностью избавляться от физического или психического напряжения;

г) постепенное расслабление какого-либо состояния тела после прекращения действия факторов.

7. Аутогенная тренировка - это...:

a) система сознательно применяемых человеком безусловных рефлексов;

б) система сознательно применяемых человеком условных рефлексов;

в) система сознательно применяемых человеком психологических приемов;

г) система сознательно применяемых человеком физических упражнений.

8. Стандартная аутогенная тренировка включает в себя.... упражнений.
a) 4;
б) 5 ;
в) 6 ;
г) 7 . 
9. Назовите задачи утренней гигиенической гимнастики.

а) вывести организм на более высокий уровень жизнедеятельности;

б) вывести на более высокий уровень физическую подготовленность человека;

в) развить и совершенствовать физические качества;

г) полноценно включить организм в предстоящую работу;

10. Укажите упражнения, которые не входят в комплекс утренней гигиенической гимнастики.

а) общеразвивающие;

б) со значительным отягощением;

в) на гибкость;

г) длительного статического характера;

д) на восстановление дыхания.

11. Как Всемирная организация здравоохранения определяет понятие «Здоровье»?

а) состояние целеполагающей жизнедеятельности, воспроизводящей психофизиологическую потребность в добровольном напряжении;

б) состояние полного физического, душевного и социального благополучия, а не только отсутствие болезни или физических дефектов;

в) естественное состояние организма, характеризующееся его уравновешенностью с окружающей средой и отсутствием каких-либо болезненных изменений.

12. Назовите интегральный показатель физического здоровья человека.

a) система внешнего дыхания; 
б) транспортная функция крови;

в) максимальное потребление кислорода (МПК)

13. Укажите, что не предполагает здоровый образ жизни.

а) рациональный режим труда и отдыха;

б) плодотворный труд;

в) минимальная физическая нагрузка.

14. Назовите группу, в которую входят перечисленные факторы риска для здоровья: нерациональное питание, чрезвычайно высокий уровень урбанизации, стрессовые ситуации.
а) образ жизни;
б) генетические факторы;
в) окружающая среда.

15. Какая из перечисленных функций не является функцией питания?
а) накопительная функция;
б) двигательная функция;
в) энергетическая функция.

16. Социально-психологическая адаптация студента - это...

a) интеграция личности со студенческой средой, принятие ее ценностей, норм, стандартов поведения;

б) идентификация (отождествление) себя с избранной профессией, с социальной ролью, которую предстоит выполнять после окончания вуза;

в) повышение уровня психической и интеллектуальной готовности студентов к вузовской специфике обучения. 
Тема 3. Основы методики самостоятельных занятий физическими упражнениями. Самоконтроль при занятиях физической культурой и спортом

1. В какой части занятия решаются задачи восстановления ЧСС?

а) в подготовительной;

б) в основной;

в) в заключительной.

2. Использование каких физических упражнений дает наибольший эффект в оздоровительной тренировке?
а) циклических;
б) ациклических;
в) общеразвивающих.

3. Мощность тренировочной нагрузки в оздоровительной тренировке составляет:
a) 10-30\% от максимальной физической работоспособности;
б) 50-70\% от максимальной физической работоспособности;
в) 70-100\% от максимальной физической работоспособности.

4. Система преимущественно силовых упражнений для женщин, направленная на коррекцию фигуры, улучшение функционального состояния организма называется:
a) ритмическая гимнастика;
б) шейпинг;
в) калланетика. 
5. Направленное использование физических упражнений с целью лечения заболеваний и восстановления функций организма называется:

а) гигиеническая физическая культура;

б) оздоровительно-реабилитационная физическая культура;

в) оздоровительно-рекреативная физическая культура.

6. Какие упражнения не используются в оздоровительной аэробной тренировке?

а) плавание;

б) скандинавская ходьба;

в) ритмичный бег;

г) бег на лыжах.

7. Разновидность оздоровительной гимнастики, в содержание которой входят, в основном, общеразвивающие упражнения, бег, прыжки, танцевальные элементы, выполняемые поточно под музыку, называется:
а) аэробика;
б) ритмическая гимнастика;
в) шейпинг.

8. Что из перечисленного не является дыхательной гимнастикой?

а) парадоксальная гимнастика, разработанная А.Н. Стрельниковой;

б) дыхательные упражнения йогов;

в) аэробные упражнения К. Купера.

9. Основной функцией утренней гигиенической гимнастики является:

а) достижение хорошей физической формы;

б) активизация деятельности организма; 
в) пропаганда здорового образа жизни.

10. Как называется программа из 30 упражнений для женщин, выполняемых в основном в изометрическом режиме и вызывающих активность глубоко расположенных мышечных групп?

а) ритмическая гимнастика;

б) шейпинг;

в) калланетика;

г) аквааэробика.

11. Как называется система физических упражнений в воде, выполняемых под музыку, сочетающая элементы плавания, гимнастики, стретчинга, силовые упражнения?
a) шейпинг;
б) аквааэробика;
в) ритмическая гимнастика;
г) калланетика.

12. Какое физическое упражнение не относится к упражнениям в виде естественны движений?
а)бег;
б) плавание;
в) ходьба;
г) упражнение, выполняемое на тренажерном устройстве.

13. Какое направление оздоровительной физической культуры представляет собой отдых, восстановление сил с помощью средств физического воспитания (занятия физическими упражнениями, подвижные и спортивные игры, туризм, физкультурно-спортивные развлечения)? 
а) оздоровительно-реабилитационная физическая культура;

б) оздоровительно-рекреативная физическая культура;

в) гигиеническая физическая культура;

г) спортивно-реабилитационная физическая культура.

14. Как называется система упражнений в циклических видах спорта, связанная с проявлением выносливости (ходьба, бег, плавание), направленная на повышение возможностей сердечно-сосудистой и дыхательной систем?
а) шейпинг;
б) аэробика;
в) калланетика;
г) ритмическая гимнастика.

15. Что в комплексе ритмической гимнастики относится к вводной части?

а) бег прыжки, танцевальные шаги;

б) ходьба на месте с высоким подниманием бедра, ходьба с движения рук и головы, выпады, наклоны, приседания;

в) дыхательные упражнения, упражнения на расслабление, спокойная ходьба.

16. Что из перечисленного не относится к формам оздоровительно-реабилитационного направления в нашей стране?

a) группы здоровья в коллективах физической культуры, на физкультурно-спортивных базах и т.д.;

б) группа ЛФК при диспансерах, больницах;

в) самостоятельные занятия;

г) занятия массовым спортом. 
17. Какой принцип обеспечивает такую организацию физического воспитания, при которой выполняется и профилактическая, и развивающая функция?

а) принцип достижения здорового образа жизни;

б) принцип достижения хорошей физической формы;

в) принцип оздоровительной направленности.

Тема 4. Социально-биологические основы физической культуры

1. Как отличаются расходы энергии в покое у тренированных и нетренированных людей?

а) общий расход энергии у нетренированного организма ниже, чем у тренированного;

б) общий расход энергии у тренированного организма ниже, чем у нетренированного.

2. Что такое тахикардия?

а) нормальный пульс;

б) учащенный пульс;

в) редкий пульс.

3. Какие мышечные волокна обладают способностью быстро и сильно сокращаться?
а) белые;
б) красные;
в) оранжевые. 
4. В соединении костей скелета между собой не принимают участие:
а) сосуды;
б) сухожилия;
в) связки.
5. Должная величина МПК (ДМПК) это:

a) средние значения нормы для данного возраста и пола;

б) средние значения нормы для данного возраста и роста;

в) средние значения нормы для данного роста и веса.

6. Конечными продуктами окисления жиров и углеводов является:
а) молочная кислота и вода;
б) молочная кислота и гликоген;
в) углекислый газ и вода.

7. Поперечно-полосатые мышцы - это вид мускулатуры;
а) скелетной;
б) сердечной;
в) гладкой.

8. У представителей каких видов спорта зарегистрированы наивысшие показатели максимального потребления кислорода(МПК)?
а) циклических видов спорта;
б) игровых видов спорта;
в) сложнокоординационных видов спорта.

9. Что используется в качестве энергетического материала при выполнении кратковременной интенсивной работы?
а) белки;
б) жиры; 
в) углеводы.

10. Какие реакции в организме человека совершаются при участии кислорода?
а) аэробные;
б) анаэробные;
в) аэродинамические.

11. С вопросами какого характера связаны природные и социально-биологические факторы, оказывающие влияние на организм человека?
а) физиологического;
б) социального;
в) экологического.

12. Учитывая биологические ритмы, тренироваться лучше:
а) в первой половине дня;
б) во второй половине дня;
в) рано утром;
г) поздно вечером.

13. Почему кости детей отличаются большей эластичностью и упругостью?

а) в их составе преобладают органические вещества;

б) в их составе преобладают неорганические вещества;

в) в их составе преобладают минеральные соли.

14. Главным источником энергии в организме являются:

a) белки; 
б) жиры;

в) углеводы.

15. Основное значение витаминов для жизнедеятельности организма в том, что они;

а) регулируют реакции обмена веществ;

б) способствуют омолаживанию;

в) являются основным лечебным средством.

Тема 5. Психофизиологические основы учебного труда и интеллектуальной деятельности. Средства физической культуры в регулировании работоспособности

1. Какие факторы не относятся к обеспечивающим качество профессиональной подготовки студентов?
а) познавательная деятельность;
б) учебно-трудовая деятельность;
в) духовно-нравственная деятельность.

2. Что, по мнению студентов-первокурсников, не относится к трудностям перехода на вузовские формы обучения?
а) необходимость налаживать межличностные отношения;
б) сложность лабораторных и практических занятий;
в) изменение системы контроля за успеваемостью;
г) необходимость организовывать самостоятельную работу.

3. Вечернюю работу студентам рекомендуется проводить...

а) период с 17 до 23 часов;

б) в период с 20 до 24 часов; 
в) в период с 18 до 20 часов.

4. Действие какой адаптации предполагает повышение уровня психической и интеллектуальной готовности студентов к обучению в вузе?

а) социально-психологическая адаптация;

б) дидактическая адаптация;

в) профессиональная адаптация;

г) все перечисленные виды адаптации.

5. К объективным признакам переутомления не относится...

а) лабильность частоты сердцебиения и артериального бавления;

б) снижение веса тела;

в) повышение сопротивляемости организма инфекциям.

6. Скрытые трудности обучения в вузе - это...

a) трудности, связанные с необходимостью усвоения большого объема знаний;

б) отдельные малозначимые обстоятельства студенческой жизни, взятые в совокупности;

в) трудности, связанные с формированием профессиональных умений и навыков.

7. Какие факторы, связанные с умственной деятельностью, снижают кровоснабжение головного мозга?

а) отрицательные эмоции;

б) нервно-психическое напряжение;

в) длительное пребывание в положении сидя за столом;

г) напряженная работа в условиях дефицита времени. 
8. К субъективным факторам, связанным с психофизическим состоянием студентов, не относится...
а) величина учебной нагрузки;
б) способность адаптироваться к условиям обучения в вузе;
в) мотивация учения.

9. Умственная усталость это:
а) субъективное ощущение человека;
б) объективное состояние организма;
в) психологическая особенность человека.

10. Умственное утомление это:
а) объективное состояние организма человека;
б) субъективное ощущение человека;
в) психофизиологическая особенность человека.

11. Укажите изменения в деятельности сердечно-сосудистой системы при умственной работе
а) увеличение кровенаполнения сосудов головного мозга;
б) сужение сосудов внутренних органов;
в) расширение периферических сосудов конечностей;
г) расширение сосудов внутренних органов.

12. Что не относится к факторам повышения уровня умственной работоспособности?
а) хорошая освещенность рабочего помещения;
б) пониженная температура воздуха;
в) тишина. 
13. Наиболее высокий уровень работоспособности студентов в недельном цикле наблюдается:

а) понедельник, вторник, среда;

б) вторник, среда, четверг;

в) суббота, воскресенье, понедельник.

14. Период врабатывания короче:

а) в весеннем семестре;

б) в осеннем семестре.

15. Состояние, вызванное снижением двигательной активности, называется:
а) гипокинезия;
б) гипоксия;
в) гиподинамия.

16. Физкультурная пауза не содержит упражнений:
a) на внимание;
б) статических;
в) на развитие аэробной выносливости.

17. В какое время у студентов происходит максимальное снижение умственной и физической работоспособности?

a) в начале и середине учебного года;

б) в начале и конце учебного года;

в) в период экзаменов.

18. Постепенным повышением работоспособности и образованием рабочей доминанты характеризуется: 

а) фаза врабатывания;
б) фаза полной компенсации;
в) фаза неустойчивой компенсации.

19. Соответствуют ли друг другу динамика умственной и физической работоспособности в течение учебной недели?
а) соответствуют;
б) не соответствуют;
в) частично соответствует

20. Оказывает и влияние на сосотяние здоровья студентов уровень их двигательной активности?
а) да;
б) нет;
в) частично.

21. Какая ткань организма человека потребляет значительно больше кислорода по сравнению с другими?
а) эпителиальная ткань;
б) мозговая ткань;
в) мышечная ткань.

22. Оказывают ли влияние на умственную работоспособность человека биологические ритмы?
а) да;
б) нет;
в) частично. 
23. К малым формам занятий физическими упражнениями в режиме дня студентов не относятся:

а) производственная гимнастика;

б) гигиеническая гимнастика;

в) оздоровительная гимнастика.

24. Двигательная активность человека - это:

a) суммарное количество движений человека за определенный отрезок времени;

б) количество движений человека, выполняемое в течение жизни;

в) количество движений человека, выполняемое в определенный период времени.

25. По характеру проявления псиофизических качеств учебную деятельность студентов можно отнести к профессиям:

a) не вызывающим постоянного умственного напряжения и не требующим длительного внимания;

б) иногда вызывающим умственное напряжение, но требующим длительного внимания;

в) вызывающим постоянное умственное напряжение и требующим длительного внимания.

26. К двигательной активности не относится:

а) спонтанная физическая активность в свободное время;

б) физическая активность, осуществляемая в процессе научно-исследовательской деятельности;

в) физическая активность в процессе физического воспитания. 
27. Людей, у которых пик работоспособности приходится на вечерние часы, называют:

a) «жаворонками»;

б) «совами»;

в) «голубями».

28. К каким факторам, влияющим на работоспособность, относят самочувствие, активность, настроение?

а) к факторам физиологического характера;

б) к факторам физического характера;

в) к факторам психического характера.

Тема 6. Общая физическая подготовка в системе физического воспитания

1. Ловкость - способность человека:

a) овладеть новыми движениями в минимальный промежуток времени;

б)постепенно овладеть новыми движениями с высокой координационной сложностью;

в) справиться с возникшей любой двигательной задачей.

2. Укажите виды ловкости:

а) телесная;

б) условная;

в) сочетание телесной и предметной;

г) сочетание телесной и условной;

д) предметная;

е) относительная. 
3. Какие параметры учитывается при оценке ловкости

а) интеллектуальная сложность двигательной задачи;

б) координационная сложность двигательной задачи;

в) точность выполнения движения;

д) время выполнения движения.

4. Выносливость - это способность:

а) длительно выполнять физическую работу умеренной мощности;

б) быстро восстанавливаться после физических упражнений;

в) противостоять утомлению.

5. Укажите виды выносливости

а) целенаправленная;

б) общая;

в) специальная.

6. Укажите разновидности специальной выносливости

а) скоростная;

б) силовая;

в) ведущая;

г) статическая;

д) базовая;

е) скоростно- силовая.

7. Быстрота - это способность человека :

а) выполнять движения с минимальным усилием;

б) быстро бегать;

в) выполнять движения в минимальный промежуток времени. 
8. Укажите средство, которое не используется для развития быстроты в затрудненных условиях:
а) бег в гору;
б) бег по песку;
в) бег с закрытыми глазами;
г) бег с сопротивлением.

9. Гибкость- это способность человека выполнять:
а) движения с большой амплитудой ;
б) движения с максимальным усилием;
в) движения с максимальной скоростью.

10. Укажите значимость гибкости для человека, занимающегося спортом :
a) способствует более экономичному выполнению упражнений;
б) способствует ускорению восстановительных процессов в организме;
в) способствует уменьшению травматизма;
г) способствует образованию двигательных навыков;
д) способствует более интенсивному выполнению упражнений.

11. Укажите средства, которые применяются для развития гибкости:
а) статические;
б) маховые;
в) простые;
г) скоростные;
д) пружинистые. 
12. Укажите факторы, влияющие на развитие гибкости:
a) температура окружающей среды;
б) половая принадлежность;
в) время суток;
г) конституция;
д) спортивная специализация;
е) предварительная разминка.

13. Сила - это способность человека преодолевать внешнее сопротивление или противостоять ему:
а) продолжительное время;
б) с минимальным усилием;
в) за счет волевых усилий;
г) посредством мышечных усилий.

14. Укажите виды силы:
а) динамическая;
б) метрическая;
в) классическая;
г) статическая.

15. Относительная сила - это величина силы:
а) относительно абсолютного усилия спортсмена;
б) приходящаяся на 1 сантиметр тела спортсмена;
в) приходящаяся на 1 килограмм поднятого веса;
г) приходящаяся на 1 килограмм веса спортсмена. 
16. Какая часть занятия физическими упражнениями предназначена для решения задач формирования двигательных умений и навыков, развития волевых и физических качеств занимающихся?
а) подготовительная;
б) основная;
в) заключительная.

17. При каком режиме работы мышц их длина уменьшается?

a) при статическом;

б) при преодолевающем;

в) при уступающем.

18. Какой формы занятий физическими упражнениями не существует?
а) упражнений в течение учебного дня;
б) утренней гигиенической гимнастики;
в) производственной физминутки;
г) самостоятельных тренировочных занятий.

19. Какая форма организации занятий физическими упражнениями считается основной?
а) гигиеническая гимнастика;
б) производственная гимнастика;
в) урочная форма.

20. Воспитание двигательных способностей, которые отражают специфику спортивной дисциплины или профессиональной деятельности это...

а) развитие физической работоспособности; 
б) общая физическая подготовка;

в) специальная физическая подготовка.

21. Как влияют на здоровье анаболические препараты, применяемые с целью увеличения мышечной массы?

а) влияют положительно;

б) влияют отрицательно;

в) никак не влияют.

22. Занятия каким видом спорта могут отрицательно сказаться на формировании правильной осанки?

а) плавание;

б) велоспорт;

в) волейбол;

г) художественная гимнастика.

23. Какой вид силы имеет определяющее значение при выполнении переворота в упор на перекладине?
а) абсолютная сила;
б) относительная сила;
в) динамическая сила.

24. Что такое общая физическая подготовка (ОФП)?

а) процесс повышения физической работоспособности;

б) процесс совершенствования физических качеств (силы, быстроты, выносливости, гибкости, ловкости), направленный на всестороннее физическое развитие человека;

в) процесс развития двигательных способностей, необходимых для нормальной жизнедеятельности человека. 
25. Самостоятельные занятия физическими упражнениями в качестве оздоровительной тренировки рекомендуется осуществлять:
А) 2 раза в неделю;
Б) 3 - 4 раза в неделю;
В) 5 - 6 раз в неделю.

\section{Тема 7. Спорт. Индивидуальный выбор видов спорта или систем физических упражнений}

1. Какое значение спорта способствует приобщению занимающихся к интересам коллектива, воспитанию духовных качеств (самообладание, воля, самоорганизация), стимулируют эмоциональную активность?
а) агитационное значение спорта;
б) спорт как средство удовлетворения зрелищных запросов человека;
в) воспитательное значение спорта;
г) престижное значение спорта.

2. Какой спорт называют зрелищно-коммерческим?
а) студенческий спорт;
б) спорт высших достижений;
в) профессиональный спорт;
г) массовый спорт.

3. Кто не имеет права участвовать в Универсиадах7
А) студенты;
Б) абитуриенты;
В) выпускники, которые окончили учебные заведения в предшествующем спортивным соревнованиям году. 
4. Что из перечисленного не является отличительной чертой соревновательной деятельности?

a) соревновательная деятельность характеризуется повышенным уровнем риска;

б) система соревнований с последовательным возрастанием уровня конкуренции и требований к достижениям (повышение ранга соревнований);

в) регламентация поведения соревнующихся в соответствии с принципами неантагонистической конкуренции, которые имеют гуманный характер;

г) унификация состава действий, посредством которых ведутся состязания, условий их выполнения и способов оценки достижений, что закрепляется официальными правилами.

5. Что такое спорт высших достижений?

a) коммерческо-спортивная деятельность, предусматривающая экономическую эффективность высокую информационно-развлекательную ценность спортивно-зрелищных мероприятий;

б) спорт, который представляет собой регулярные занятия и участие в соревнованиях представителей различных возрастных групп в доступных им видах спорта с целью укрепления здоровья, коррекции физического развития и телосложения, повышения общей и специальной работоспособности, овладения отдельными жизненно необходимыми умениями и навыками, активного отдыха, достижения физического совершенства;

в) спорт, который предполагает систематическую плановую многолетнюю подготовку и участие в соревнованиях в избранном виде 
спорта с целью достижения максимально возможных спортивных результатов, победы на крупнейших спортивных соревнованиях.

6. Какое значение спорта способствует развитию интереса к крупнейшим международным соревнованиям, особенно к Олимпийским играм?
a) престижное значение спорта;
б) агитационное значение спорта;
в) воспитательное значение спорта;
г) спорт как средство удовлетворения зрелищных запросов человека.

7. Что такое профессиональный спорт?

a) спорт, который представляет собой регулярные занятия и участие в соревнованиях представителей различных возрастных групп в доступных им видах спорта с целью укрепления здоровья, коррекции физического развития и телосложения, повышения общей и специальной работоспособности, овладения отдельными жизненно необходимыми умениями и навыками, активного отдыха, достижения физического совершенства;

б) коммерческо-спортивная деятельность, предусматривающая экономическую эффективность и высокую информационно-развлекательную ценность спортивно-зрелищных мероприятий;

в) спорт, который предполагает систематическую плановую многолетнюю подготовку и участие в соревнованиях в избранном виде спорта с целью достижения максимально возможных спортивных результатов, победы на крупнейших спортивных соревнованиях.

8. Что такое спорт? 
a) процесс физического образования и воспитания, выражающий высокую степень развития индивидуальных физических способностей;

б) часть общей культуры общества, отражающая способы физкультурной деятельности, результаты, условия, необходимые для культивирования, направленные на освоение, развитие и управление физическими и психическими способностями человека, укрепление его здоровья, повышение работоспособности;

в) составная часть физической культуры, средство и метод физического воспитания, основанный на использовании соревновательной деятельности и подготовке к ней, в процессе которой сравниваются и оцениваются потенциальные возможности человека.

9. С какой периодичностью проводятся Всемирные Универсиады (летние и зимние)?

один раз в четыре года
А) один раз в два года (каждый нечетный год);
Б) один раз в два года (каждый четный год);
В) один раз в три года.

10. Какой эффект является важным социально-психологическим феноменом в спорте?
а) оздоровительный эффект;
б) эффект быстрого физического развития;
в) эффект соперничества.

11. Разделение каких разновидностей спорта в настоящее время очень условно?
а) олимпийского и профессионального спорта;
б) олимпийского и массового спорта; 
в) профессионального и массового спорта.

12. Какой спорт по-другому называют олимпийским?

а) профессиональный спорт;

б) массовый спорт;

в) спорт высших достижений;

г) студенческий спорт.

13. Что такое массовый спорт (спорт для сех)?

a) спорт, который предполагает систематическую плановую многолетнюю подготовку и участие в соревнованиях в избранном виде спорта с целью достижения максимально возможных спортивных результатов, победы на крупнейших спортивных соревнованиях;

б) регулярные занятия и участие в соревнованиях представителей различных возрастных групп в доступных им видах спорта с целью укрепления здоровья, коррекции физического развития и телосложения, повышения общей и специальной работоспособности, овладения отдельными жизненно необходимыми умениями и навыками, активного отдыха, достижения физического совершенства;

в) коммерческо-спортивная деятельность, предусматривающая экономическую эффективность и высокую информационно-развлекательную ценность спортивно-зрелищных мероприятий.

14. Какой спорт представляет на сегодняшний день единственную модель деятельности, при которой у выдающихся рекордсменов функционирование почти всех систем организма может проявляться в зоне абсолютных физиологических и психологических пределов здорового человека? 

a) спорт высших достижений;
б) массовый спорт;
в) студенческий спорт;
г) профессиональный спорт.

15. Какой спорт дает возможность миллионам людей совершенствовать свои физические качества и двигательные возможности, укреплять здоровья и продлевать творческое долголетие, a значит противостоять нежелательным воздействиям на организм современного производства и условий современной жизни?
а) профессиональный спорт;
б) спорт высших достижений;
в) массовый спорт;
г) студенческий спорт.

16. Где и когда состоялись первые Олимпийские Игры современности?
a) в Чикаго в 1930 году;
б) в Афинах в 1896 году;
в) в Турине в 1915 году.

17. Какое значение спорта способствует привлечению к занятиям физическими упражнениями?
а) воспитательное значение спорта;
б) агитационное значение спорта;
в) спорт как средство удовлетворения зрелищных запросов человека;
г) престижное значение спорта. 
18. К какой из задач относится формирование качеств, общая волевая и специальная психологическая подготовка, формирование специальных норм спортивной этики?
а) воспитательной;
б) оздоровительный
в) образовательный.

19. Для каких спортсменов характерно обладание способностью к предельно интенсивным усилиям импульсивного характера максимально концентрированным во времени, но не продолжительным и часто повторяющимися:

а) бегун-стайер;

б) прыгун и метатель;

в) прыгун на лыжах с трамплина.

20. Оперативное регулирование эмоционально -волевых проявлений в ходе состязаний или напряженной тренировки- это одна из задач:
a) тактической подготовки;
б) технической подготовки;
в) психологической подготовки.

21. Перечислите 3 группы препаратов, относящихся к допинговым средствам:
а) витамины;
б) психотропные стимуляторы;
в) наркотики и болеутоляющие;
г) микроэлементы;
д) анаболические стероиды. 
22. К циклическим упражнениям относятся (укажите 2 правильных ответа):
а) спортивные игры;
б) плавание;
в) езда на велосипеде;
г) прыжки в высоту;
д) фигурное катание.

23. К ациклическим упражнениям относятся (укажите 3 правильных ответа):
а) бег;
б) единоборства;
в) водные лыжи;
г) гребля;
д) акробатические упражнения.

24. Какой вид дистанции относится к зоне большой мощности?
а) легкоатлетический бег 20,30 км;
б) спортивное плавание 25,50 км;
в) велогонки 5,10км.

24. Длительность упражнений в зоне максимальной мощности колебания от:
a) 20-30 сек;
б) 40 сек до 3-5мин;
в) 40 мин до 3 часов.

26. Физическими качествами человека являются (укажите 3 правильных ответа): 

a) сила;
б) внимательность;
в) ловкость;
г) уравновешенность;
д) выносливость.

27.В каком году первый раз советские спортсмены выступили в Олимпийских играх?
a) 1948 ;
б) 1952 ;
в) 1956 ;
в) 1960 .

\section{Тема 8. Профессионально-прикладная физическая культура}

1. Какая разновидность производственной гимнастики выполняется до начала работы с целью активизации деятельности организма и сокращения времени врабатывания в начальном периоде рабочего дня?
а) вводная гимнастика;
б) физкультурная пауза;
в) физкультурная минутка.

2. Факторы, определяющие содержание профессионально-прикладной физической подготовки:
а) финансово-экономическое состояние сферы деятельности;
б)содержание и условия труда;
в) востребованность профессии. 
3. К какой группе профессий относится труд менеджера, юриста, экономиста:

а) умственный и преимущественно умственный труд;

б)малоподвижный, однообразный лёгкий физический труд ;

в) тяжёлый физический труд.

4. Профессионально-прикладную физическую подготовку следует проводить:

а) круглогодично;

б)во вне учебное время;

в) в каникулярное время.

5. Профессиональная деятельность экономиста, менеджера, юриста характеризуется:

a) монотонностью, гипокинезией и гиподинамией, преобладанием умственной деятельности;

б)значительной умственной нагрузкой, высокой трудоспособностью в экстремальных условиях;

в) высокой координацией движений, их автоматизмом, физической силой.

6. В каких видах спорта ярко выражено воздействие на развитие двигательных и тесно сопряженных с ними способностей, имеющих существенное значение для совершенствования в профессиональной деятельности?

а) в профессионально-прикладных видах спорта;

б) в общеприкладных видах спорта;

в в собственно-прикладных видах спорта. 
7. Когда в нашей стране начала формироваться система профессионально-прикладной физической подготовки?

а)в 50-е годы XX века;

б) в 30-е годы XX века;

в) в 10-е годы XX века;

г) в 70-е годы XX века.

8. С чем должна быть тесно связана профессионально-прикладная физическая подготовка?

a) с общей физической подготовкой (ОФП);

б) со специальной физической подготовкой (СФП);

в) наличие такой взаимосвязи необязательно.

9. Что из перечисленного не относится к видам производственной физической культуры во внерабочее время?

а) занятия в спортивных секциях;

б) занятия в группах здоровья (ГЗ);

в) занятие массовым спортом;

г) оздоровительно-профилактическая гимнастика (ОПГ).

10. Что такое физическая подготовка?

а) процесс развития физической работоспособности;

б) процесс развития физических качеств;

в) процесс развития силы.

11. Как называются упражнения, посредством которых вырабатывают двигательные умения и навыки, находящие применение в 
обычных условиях профессиональной деятельности или в экстремальных условиях, вероятных в ней?

а) собственно-прикладные упражнения;

б) общеприкладные упражнения;

в) профессионально-прикладные упражнения.

12. На чем в основном базируется методика профессионально-прикладной физической подготовки?

a) на последовательном воплощении общепсихологических принципов и основополагающих принципов методики физического воспитания;

б) на последовательном воплощении общепедагогических принципов и основополагающих принципов методики физического воспитания;

в) на последовательном воплощении общепедагогических и психологических принципов.

13. Какой вид адаптации не имеет особого значения для становления личности специалиста?

а) профессиональная адаптация;

б) дидактическая адаптация;

в) социально-психологическая адаптация;

г) филогенетическая адаптация.

14. K какой группе профессий относятся следующие из них инженеры, врачи, техники, программисты, научные работники, операторы, преподаватели?

а) к профессиям, связанным с легкими однообразными движениями; б) к профессиям, связанным с тяжелым физическим трудом, с большими энергетическими затратами;

в) к профессиям, связанным с умственным трудом. 
15. Что имеет важнейшее значение для рационального построения профессионально-прикладной физической подготовки?

a) обеспечение органической взаимосвязи, единства общей и специальной физической подготовки;

б) наличие специальной физической подготовки;

в) наличие общей физической подготовки.

16. К представителям каких профессий можно отнести студентов по характеру проявления психофизических качеств?

а) к представителям профессий, чей труд не вызывает постоянного умственного напряжения и не требует длительного внимания;

б) к представителям профессий, чей труд иногда вызывает умственное напряжение, но требует длительного внимания;

в) к представителям профессий, чей труд вызывает постоянное умственное напряжение и требует длительного внимания.

17. Что такое производственная гимнастика?

a) физические упражнения, проводимые при появлении первых признаков утомления;

б) физические упражнения для устранения застойных явлений в мышцах;

в) физические упражнения в режиме рабочего дня для повышения профессиональной работоспособности, снятия утомления и профилактики профессиональных заболеваний;

г) физические упражнения перед началом работы для сокращения времени врабатывания.

18. Какие виды спорта являются собственно-прикладными для военнослужащих и оперативных работников органов МВД? 
a) планерный и парашютный спорт;

б) спортивный туризм и соответствующие разновидности спортивного ориентирования;

в) водно-моторный и парусный спорт;

г) ряд прикладных спортивных многоборий и единоборств.

19. К какой группе профессий относятся следующие из них каменщик, грузчик, лесоруб, кузнец, формовщик?

а) к профессиям, связанным с тяжелым физическим трудом, с большими энергетическими;

б) к профессиям, связанным с умственным трудом;

в) к профессиям, связанным со всевозможными станками, механическими приспособлениями и инструментами;

г) к профессиям, связанным с легкими однообразными движениями.

20. Какие по форме упражнения используют в процессе профессионально-прикладной физической подготовки для воспитания общей выносливости?

а) прикладную гимнастику и упражнения на координацию движений; б) аэробный бег и другие упражнения циклического характера;

в) виды упражнений, в процессе выполнения которых существенно возрастает температура тела.

21. Представители какой группы профессий поднимают за смену несколько тонн условного груза в положении стоя, прилагая очень большие физические усилия?

а) профессий, связанных с тяжелым физическим трудом, с большими энергетическими;

б) профессий, связанных с легкими однообразными движениями;

в) профессий, связанных со всевозможными станками, механическими 
приспособлениями и инструментами

профессий, связанных с умственным трудом.

22. Что из перечисленного не относится к основным физиологическим показателям, которые необходимо учитывать при оценке степени тяжести труда?

a) температура тела;

б) потребление кислорода;

в) частота сердечных сокращений;

г) средний уровень потери воды через кожу и легкие за смену;

д) минутный объем дыхания.

23. Какой вид спорта не является собственно-прикладным для готовящихся стать профессиональными водителями автотранспорта?

а) мотоциклетный спорт;

б) планерный спорт;

в) автомобильный спорт.

24. К какой группе профессий относятся рабочие конвейеров и автоматических линий?

а) к профессиям, связанным с легкими однообразными движениями; б) к профессиям, связанным со всевозможными станками, механическими приспособлениями и инструментами;

в) к профессиям, связанным с тяжелым физическим трудом, с большими энергетическими затратами;

г) к профессиям, связанным с умственным трудом. 


\section{СПИСОК РЕКОМЕНДУЕМОЙ ЛИТЕРАТУРЫ}

\section{Основная литература:}

1. Евсеев, Ю.И. Физическая культура [Текст]: Учебное пособие для студентов Вузов / Ю.И. Евсеев.- М.: Феникс 2010.

2. Максименко, А.М. Теория и методика физической культуры [Текст]: Учебник / А.М. Максименко. - М.: Физическая культура, 2009.

3. Физическая культура студента [Текст]: Учебник для студентов вузов./ Под ред. В.И. Ильинича. - М.: Гардарики, 2007.

4. Физическая культура [Текст]: Учебник для студентов технических вузов / Под ред. В.А. Коваленко. - М.: АСВ, 2000.

Дополнительная литература:

1. Амосов, Н.М. Раздумья о здоровье [Текст] / Н.М. Амосов. - М.: АСТ, Сталкер, 2005.

2. Анатомия человека [Текст]: Учебное пособие / В.Г.Николаев и др. - Ростов нЦД., «Феникс», 2006.

3. Анатомия человека [Текст]: Учебник / Под ред. Л.Л. Колесникова, М.М. Михайлова. - М.:ГЭОТАР - Медиа, 2010.

4. Анищенко, В.С. Физическая культура. Методико-практические занятия студентов [Текст] / В.С. Анищенко. - М.: Издание Российского университета дружбы народов, 1999.

5. Белов, В.И., Михайлович, Ф.Ф. Валеология: здоровье, молодость, красота, долголетие [Текст] / В.И. Белов, Ф.Ф. Михайлович. - М.: «Недра Коммюникейшенс Лтд», 1999.

6. Бирюков, А.А. Массаж и самомассаж [Текст] / А.А. Бирюков. Ростов н\Д: Феникс, 2000.

7. Бочкарева, С.И. Самостоятельные занятия студентов физическими упражнениями [Текст]: Методическое пособие / С.И. Бочкарева. - М.: МГУЭСИ, 2004. 
8. Виленский, М.Я. Физическая культура работников умственного труда [Текст] / М.Я. Виленский. - М.: ФиС, 1987.

9. Готовцев, П.И., Дубровский, В.И. Самоконтроль при занятиях физкультурой и спортом [Текст] / П.И. Готовцев, В.И. Дубровский. - М.: ФКиС, 1986.

10. Грачев, О.К. Физическая культура [Текст]: Учебное пособие / О.К. Грачев. - М.: ИКЦ «МарТ», 2005.

11. Динейка, К.В. Движение, дыхание, психофизическая тренировка [Текст] / К.В. Динейка. - М.; ФиС 1986.

12. Дубровский, В.И. Спортивная медицина [Текст]: Учебник для студентов вузов / В.И. Дубровский. - М.: Владас, 2002.

13. Дубровский, В.И. Валеология. Здоровый образ жизни [Текст]: Учебник / В.И. Дубровский. - М.: RETORICA-A, 2001.

14. Ильин, Е.П. Психофизиология физического воспитания [Текст]: Учебное пособие для студентов пед. ин-тов / Е.П. Ильин. - М.: Просвещение, 1983.

15. Кокоулина, О.П. Основы теории методики физической культуры и спорта [Текст]: Учебно-методическое пособие / О.П. Кокоулина. - М.: МГУЭСИ 2007.

16. Купер, К. Аэробика для хорошего самочувствия [Текст] / К. Купер. - М.: ФиС, 1989.

17. Ланда, Б.Х. Методика комплексной оценки физического развития и физической подготовленности [Текст] / Б.Х. Ланда. - М: 2005.

18. Максименко, А.М. Основы теории и методики физической культуры [Текст] / А.М. Максименко. - М.; ФиС, 2001.

19. Матвеев Л.П. Теория и методика физической культуры [Текст]: Учебник для ин-ов физической культуры / Л.П. Матвеев. - М.: Лань. Омега, 2004. 
20. Немов, Р.С. Общая психология [Текст] / Р.С. Немов. - СПб.: Питер, 2006.

21. Спортивно-оздоровительный бег [Текст]: Рекомендации для тренирующихся самостоятельно. - М. Советский спорт, 2004.

22. Холодов, Ж.К., Кузнецов, В.С. Теория и методика физического воспитания и спорта [Текст]: Учебное пособие для студентов высших учебных заведений / Ж.К. Холодов, В.С. Кузнецов. - 2-е изд., испр. и доп. - М.: Издательский центр «Академия», 2003. 
Кузьмина Наталья Сергеевна

\title{
ФИЗИЧЕСКАЯ КУЛЬТУРА
}

\author{
Учебное пособие
}

Книга издана в авторской редакичии.

Дизайн обложки: Р.В. Орлов

Доступ к пособию - свободный.

Режим доступа: http://nkras.ru/arhiv/2021/KuzminaNS.pdf

Пособие содержится в едином файле PDF.

Дата выхода в свет 12.03.2021.

Свободная цена. Заказ ФК1203/21.

По вопросам приобретения и издания литературы обращаться по адресу:

Издательство НИЦ

ул. 9 Мая, 5/192, г. Красноярск, 660127 Россия

тел. +7 (923) 358-10-20

Электронная почта: monography@nkras.ru

Дополнительная информация на сайте: www.nkras.ru 
